UNIVERSIDADE DE SÃO PAULO

FACULDADE DE FILOSOFIA, LETRAS E CIÊNCIAS HUMANAS PROGRAMA DE PÓS-GRADUAÇÃO EM SOCIOLOGIA DEPARTAMENTO DE SOCIOLOGIA

BRIAN HENRIQUE DE ASSIS FUENTES REQUENA

\title{
A UNIVERSIDADE DO SERTÃO: \\ O NOVO RETRATO CULTURAL DA MÚSICA SERTANEJA
}

VERSÃO CORRIGIDA

SÃO PAULO 


\section{A UNIVERSIDADE DO SERTÃO: O NOVO RETRATO CULTURAL DA MÚSICA SERTANEJA}

Dissertação de Mestrado apresentada ao Programa de PósGraduação em Sociologia (PPGS) da Faculdade de Filosofia, Letras e Ciências Humanas (FFLCH) da Universidade de São Paulo (USP), como requisito para obtenção do título de Mestre em Sociologia.

Área de concentração: Sociologia da Cultura.

Orientador: Prof. Dr. Sergio Miceli Pessôa de Barros.

De acordo

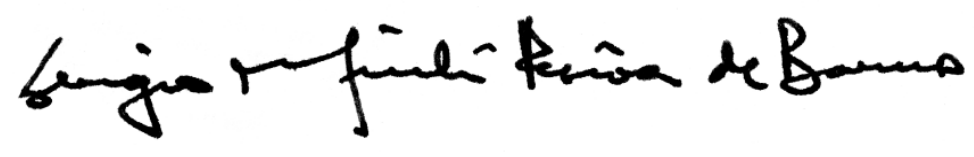

VERSÃO CORRIGIDA

SÃO PAULO 


\begin{abstract}
AUTORIZO A REPRODUÇÃO E DIVULGAÇÃO TOTAL OU PARCIAL DESTE TRABALHO, POR QUALQUER MEIO CONVENCIONAL OU ELETRÔNICO, PARA FINS DE ESTUDO E PESQUISA, DESDE QUE CITADA A FONTE.
\end{abstract}

Catalogação na Publicação

Serviço de Biblioteca e Documentação

Faculdade de Filosofia, Letras e Ciências Humanas da Universidade de São Paulo.

Requena, Brian Henrique de Assis Fuentes.

R427 u A universidade do sertão: o novo retrato cultural da música sertaneja / Brian Henrique de Assis Fuentes

Requena; orientador Sergio Miceli Pessôa de Barros.

- São Paulo, 2016.

$203 \mathrm{f}$.

Dissertação (Mestrado)- Faculdade de Filosofia, Letras e Ciências Humanas da Universidade de São Paulo. Departamento de Sociologia. Área de concentração: Sociologia.

1. Sociologia da Cultura. 2. Música Sertaneja.

3. Indústria Cultural. 4. Música Popular Brasileira. 5. História Social. I. Barros, Sergio Miceli Pessôa de orientador. II. Título. 
REQUENA, Brian Henrique de Assis Fuentes.

\section{A UNIVERSIDADE DO SERTÃO: O NOVO RETRATO CULTURAL DA MÚSICA SERTANEJA.}

Dissertação de Mestrado apresentada ao Programa de Pós-

Graduação em Sociologia (PPGS) da Faculdade de

Filosofia, Letras e Ciências Humanas (FFLCH) da

Universidade de São Paulo (USP), como requisito para a obtenção do título de Mestre em Sociologia.

Aprovado em: 21/outubro/2016

$\underline{\text { Banca Examinadora }}$

Prof. Dr. Sergio Miceli Pessôa de Barros -

(Orientador)

Prof. Dr. Fernando Antonio Pinheiro Filho -

Universidade de São Paulo

Prof. Dr. Dmitri Cerboncini Fernandes -

Universidade Federal de Juiz de Fora 


\section{Universidade de São Paulo}

\section{ATA DE DEFESA}

Aluno: 8132 - $8487846-1 /$ Página 1 de 1

Ata de defesa pública de Dissertação do(a) Senhor(a) Brian Henrique de Assis Fuentes Requena no Programa: Sociologia, do(a) Faculdade de Filosofia, Letras e Ciências Humanas da Universidade de São Paulo.

Aos 21 dias do mês de outubro de 2016, no(a) Sala de Eventos realizou-se a Defesa da Dissertação do(a) Senhor(a) Brian Henrique de Assis Fuentes Requena, apresentada para a obtenção do título de Mestre intitulada:

"A universidade do sertão: o novo retrato cultural da música sertaneja"

Após declarada aberta a sessão, o(a) Sr(a) Presidente passa a palavra ao candidato para exposição e a seguir aos examinadores para as devidas arguições que se desenvolvem nos termos regimentais. Em seguida, a Comissão Julgadora proclama o resultado:

$\begin{array}{llll}\text { Nome dos Participantes da Banca } & \text { Função } & \text { Sigla da CPG } & \text { Resultado } \\ \text { Sergio Miceli Pessoa de Barros } & \text { Presidente } & \text { FFLCH - USP } & \text { Aprovado } \\ \text { Fernando Antonio Pinheiro Filho } & \text { Titular } & \text { FFLCH - USP } & \text { Aprovado } \\ \text { Dmitri Cerboncini Fernandes } & \text { Titular } & \text { UFJF - Externo } & \text { Aprovado }\end{array}$

Resultado Final: Aprovado

\section{Parecer da Comissão Julgadora *}

A banca quer ressaltar a originalidade na construção do objeto, o tratamento expressivo da documentação - musical e iconográfica -, e a montagem do argumento sociológico. Considera ainda que o trabalho merece publicação após a devida revisão.

Eu, Daiane Neres da Silva

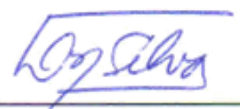
, lavrei a presente ata, que assino juntamente com os(as) Senhores(as) examinadores. São Paulo, aos 21 dias do mês de outubrodte 2016.

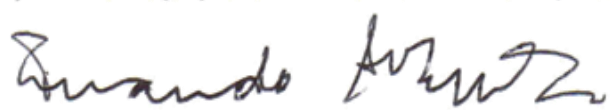

Fernando Antonio Pinheiro Filho

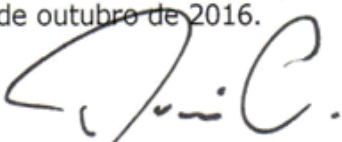

Dmitri Cerboncini Fernandes
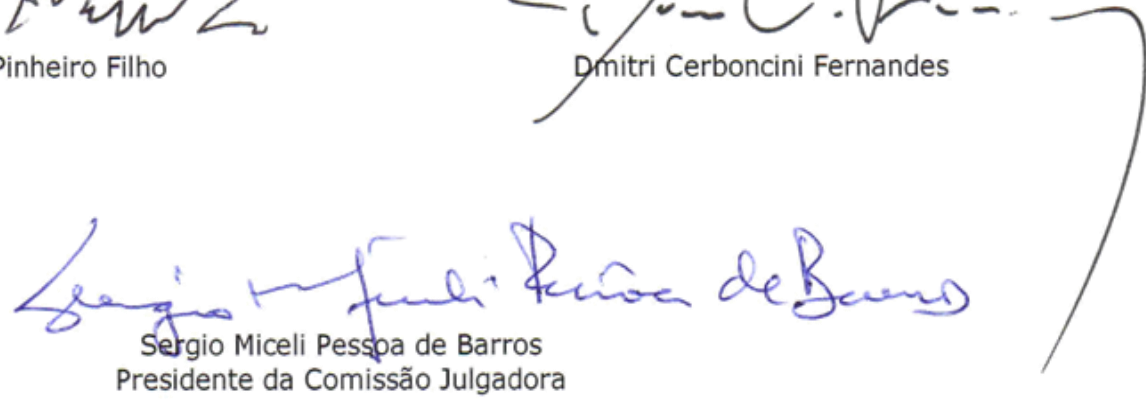

* Obs: Se o candidato for reprovado por algum dos membros, o preenchimento do parecer é obrigatório.

A defesa foi homologada pela Comissão de Pós-Graduação em 21,101206 e, portanto, o(a) aluno(a) faz jus ao título de Mestre em Ciências obtido no Programa Sociologia.

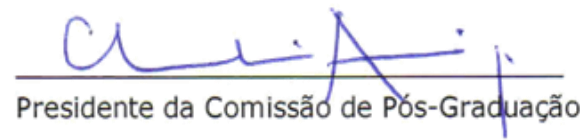


É de sonho e de pó

O destino de um só

Feito eu perdido

Em pensamentos

Sobre o meu cavalo

É de laço e de nó

De jibeira o jiló

Dessa vida

Cumprida a sol

O meu pai foi peão

Minha mãe solidão

Meus irmãos

Perderam-se na vida

À custa de aventuras

Descasei, joguei

Investi, desisti

Se há sorte

Eu não sei, nunca vi

Me disseram, porém

Que eu viesse aqui

Pra pedir de

Romaria e prece

Paz nos desaventos

Como eu não sei rezar

Só queria mostrar

Meu olhar, meu olhar

Meu olhar

Sou caipira, Pirapora

Nossa Senhora de Aparecida

Ilumina a mina escura e funda

$\mathrm{O}$ trem da minha vida

Sou caipira, Pirapora

Nossa Senhora de Aparecida

Ilumina a mina escura e funda

O trem da minha vida ${ }^{1}$.
Dedico este trabalho à memória de mamãe - Maria de Assis (1955-2011). Para homenageá-la, trouxe a letra de sua canção favorita que, por sinal, foi também a trilha sonora da sua breve existência entre nós. Deixo registrado aqui, além da saudade perpétua, meus sinceros sentimentos de gratidão, respeito, admiração e amor incondicional por essa humilde caipira lá das bandas das Minas Gerais.

\footnotetext{
${ }^{1}$ Romaria, 1977. Intérprete: Elis Regina. Composição: Renato Teixeira.
} 


\section{AGRADECIMENTOS}

Foram muitas as mãos amigas que colaboraram para o resultado final deste trabalho. Em 2012, abandonei o jornalismo cultural e me tornei um migrante forasteiro na sociologia da cultura da USP. Confesso que o caminho até aqui não foi nada fácil. Portanto, todos os nomes que citarei foram os corresponsáveis pelo meu êxito. Dedico especialmente à Prof. ${ }^{a}$ Maria de Lourdes Eleutério que, há tantos anos, não tem poupado dedicação, votos e créditos à minha trajetória acadêmica. Sou grato ao meu orientador Sergio Miceli, por ter me recebido de braços abertos na sociologia uspiana. Obrigado também pelos "puxões de orelha" bem merecidos que levei e por sua inesgotável paciência em entender minhas limitações de aluno ainda inexperiente. Ao meu companheiro Felipe Zukauskas, um analista de sistema com "alma de sociólogo", que acompanhou os meus tropeços e compartilhou minhas aflições sem reclamar. O seu apoio total e irrestrito foi mais insistente do que o meu pessimismo. À Adriana Manzo Castello que, desde 2013, aceitou a sublime tarefa de ser o meu "anjo da guarda”. Ao meu pai Francisco José Fuentes Requena pelo investimento financeiro nos meus estudos.

Gostaria de agradecer aos docentes do Departamento de Sociologia da FFLCH-USP, que, gentilmente, dispuseram-se a colaborar com o andamento desta pesquisa. Sou grato especialmente à Prof. ${ }^{a}$ Maria Arminda do Nascimento Arruda que, em 2013, aceitou minha participação como estagiário nos projetos culturais desenvolvidos dentro da PRCEU-USP e, depois, esteve presente no meu exame de qualificação. Ao Prof. Fernando Antonio Pinheiro Filho, que sem hesitar acompanhou diretamente todas as etapas da dissertação e foi uma figura decisiva na institucionalização do saber sociológico para mim. Ao Prof. Luiz Carlos Jackson, por seu comprometimento em ler, sugerir e discutir os textos produzidos durante os três anos de mestrado. À Prof. ${ }^{a}$ Sylvia Gemignani Garcia, pela valiosa oportunidade do estágio supervisionado em docência, no curso de Sociologia da Educação. Meus agradecimentos à Mônica Isabel Moraes, uma inestimável amiga, que tanto se dispôs a trocar figurinhas comigo durante as caronas, à Flavia “Adorno" Brancalion, ao poeta sociólogo João Victor Kosicki, ao Pedro Serrano, ao Rodrigo Amaral, ao Tony Nakatany, à Bruna Nicodemos, ao Gabriel Milanez, à Aline Chiaramonte, à Joyce Ribeiro, ao Matheus Jung, à Ana Carolina Roman, à Érica Magi (a musa sociológica do rock), à Lidiane Soares Rodrigues, 
à Vanessa Gatti e aos demais amigos da FFLCH, pelo intercâmbio intelectual e companheirismo social.

Dedico aos meus familiares espalhados por São Paulo e Minas Gerais, especialmente à minha irmã Juliane Camile, ao meu primo-irmão Jean Paulo Alves dos Santos, ao Lucas e à Aline Araújo, às tias Silvia e Mafalda, ao tio Silvano, à Lilian e à Joelma e Lilian Castro, à Elisíria Gouveia, à Flavia Aparecida e ao Kaique de Assis Matos. Obrigado também aos amigos de São Paulo que, desde a partida de mamãe, tornaram-se membros da minha nova família: Karina e Aurinha Makiyama, Tenille Avanci, Neide Gasparetto, Mario Marchi, Magali Mabujade, Zélia Castro, o casal Euclides e Marina, Nathália Albar e seus pais Robson e Vera Cordeiro, Cristine Lore Cavalheiro, Roberto Lucas e Sônia Leme, Renato Ber, Juliane Henrique, André Luiz Oberleitner e Fábio Barreto. Obrigado às minhas grandes e inesquecíveis amigas de Limeira, Izabel Ribeiro, Juliana Boro e Bruna Medeiros, que, aliás, não escondem a paixão pela música sertaneja - e sem o sufixo universitário.

Os meus sinceros agradecimentos aos professores Marcos Napolitano e Ivan Vilela que tanto cooperaram para o desenvolvimento deste projeto. Especialmente, dedico ao Prof. Dmitri Cerboncini Fernandes, que esteve presente na defesa de mestrado e também foi o mentor responsável pela publicação deste trabalho. Quero agradecer a boa-vontade com que os jornalistas Helder Maldonado e André Piunti receberam meus questionamentos sobre a música sertaneja, principalmente, por oferecerem pistas fundamentais para o trabalho. Obrigado ainda à Deia Neves, Edy Betty, Elaine Silva, Monaliza Vilaça e Fernanda Rodrigues. Sem a ajuda de todas vocês, seria impossível ter avançado na pesquisa de campo. Sou grato às assessoras de imprensa Juliana Chiavassa (V\&L) e Bete Ferreira (F\&S) pelas credenciais cedidas nos shows e também pelo acesso aos bastidores e aos artistas. Por último, dedico àqueles que são os protagonistas deste trabalho: Victor Chaves, Leonardo Chaves, Fernando Fakri de Assis "Sorocaba" e Fernando Zorzanello. De antemão, peço que enxerguem nesta dissertação sociológica uma tentativa de trazê-los ao universo acadêmico. Tudo o que for discutido nas próximas páginas tem caráter estritamente artístico e não pessoal.

Obrigado ao $\mathrm{CNPq}$, pela concessão da bolsa de estudos que viabilizou a realização desta pesquisa.

São Paulo, dezembro de 2016. 


\section{NOTA AO LEITOR}

Este trabalho foi o resultado da minha dissertação de mestrado em sociologia, defendida no Programa de Pós-Graduação em Sociologia da Faculdade de Filosofia, Letras e Ciências Humanas da Universidade de São Paulo, no ano de 2016. Durante a defesa, os professores Sergio Miceli Pessôa de Barros (orientador), Fernando Antonio Pinheiro Filho (Universidade de São Paulo) e Dmitri Cerboncini Fernandes (Universidade Federal de Juiz de Fora) fizeram relevantes sugestões, observações e críticas em relação ao trabalho apresentado. Entretanto, optei por mantê-lo na íntegra, pois servirá como registro oficial do meu desenvolvimento intelectual e também como um marcador pessoal da minha transição acadêmica da Comunicação Social para a Sociologia. Portanto, a versão corrigida entregue em dezembro de 2016 contém somente uma revisão gramatical e ortográfica do texto. 
Essa é a história de um novo herói

Cabelos compridos a rolar no vento

Pela estrada no seu caminhão

Gravado no peito a sombra de um dragão

Tinha um sonho ir pra Nova York

Levar a namorada

Fazer seu caminhão voar nas nuvens

Mas enquanto isso na estrada

Saudade vai, vai, vai...

Saudade vem, vem, vem te buscar ${ }^{2}$.

Eu mesmo tenho frequentemente lembrado que, se existe uma verdade, é que a verdade é um lugar de lutas. Essa afirmativa é particularmente válida para os universos sociais relativamente autônomos que chamo de campos, nos quais profissionais da produção simbólica enfrentam-se em lutas que têm como alvo a imposição de princípios legítimos de visão e de divisão do mundo natural e do mundo social ${ }^{3}$.

A tradição é na prática a expressão mais evidente das pressões e limites dominantes e hegemônicos. É sempre mais do que um segmento inerte historicizado; na verdade, é o meio prático de incorporação mais poderoso. O que temos de ver não é apenas "uma tradição", mas uma tradição seletiva: uma versão intencionalmente seletiva de um passado modelador e de um presente pré-modelado, que se torna poderosamente operativa no processo de definição e identificação social e cultural. Numa cultura particular, certos significados e práticas são escolhidos para ênfase e certos outros significados e práticas são postos de lado, ou negligenciados. É uma versão do passado que se deve ligar ao presente e ratificá-lo. O que ela oferece na prática é um senso de continuidade predisposta. Essa luta a favor e contra as tradições seletivas é, compreensivelmente, uma parte importante de toda a atividade cultural contemporânea ${ }^{4}$.

\footnotetext{
${ }^{2}$ Nova York, Chrystian e Ralf. Álbum: Acústico, 1998 - Gravadora Warner. Nota: A gravação deste CD marcou a estreia do formato acústico na música sertaneja.

${ }^{3}$ BOURDIEU, Pierre. Razões Práticas: Sobre a Teoria da Ação. Campinas: Papirus, 1996, p.83.

${ }^{4}$ WILLIAMS, Raymond. Marxismo e Literatura. Rio de Janeiro: Zahar, 1979, p.118.
} 


\section{RESUMO}

Esta dissertação consiste em um trabalho de investigação da trajetória social dos novos artistas da música sertaneja. Em menos de uma década, o gênero tem logrado êxito comercial significativo e ascendente, não somente no mercado de vendas de CD's e DVD's, mas também na liderança das listas de arrecadações de direitos autorais e na agenda de shows ao vivo da indústria fonográfica brasileira. Desde os anos 2000, a institucionalização do sufixo "universitário" na música sertaneja foi acompanhada de controvérsia entre os próprios artistas. Entretanto, a contestação ou a defesa de uma identidade musical legítima não é um tema recente dentro do cancioneiro sertanejo. Há quase um século, a discussão sobre uma suposta autenticidade da música sertaneja tradicional tem atravessado a história social do gênero. Portanto, um dos intuitos fundamentais será reexaminar as atuais configurações desse debate. De modo concomitante, a pesquisa abordará quais foram as condições objetivas, históricas, econômicas, sociais e culturais que permitiram tanto o rearranjo institucional do mercado fonográfico quanto a atualização da música sertaneja junto ao público-consumidor do gênero. Para ilustrar o novo cenário cultural da música sertaneja, será apresentado o estudo de caso de dois duetos sertanejos adversários e consagrados comercialmente: Victor e Leo e Fernando e Sorocaba.

Palavras-chave: música popular brasileira; história social da música sertaneja; identidade musical; música sertaneja universitária; indústria fonográfica. 


\begin{abstract}
This dissertation consists of an investigation work of the social trajectory of the new artists of música sertaneja. In less than a decade, the genre has achieved a commercial success significant and ascendant, not only in the sale market of CD's and DVD's, but also at the top of the lists of copyrights collection and in the agenda of live shows of the brazilian phonographic industry. Since the years 2000, the institutionalization of the suffix "universitário" in the música sertaneja was accompanied by controversy between the artists themselves. However, the contestation or the defense of a legitimate musical identity is not a recent theme in the sertanejo songbook. For almost a century, the discussion about a supposed authenticity of the traditional música sertaneja has crossed the social history of the genre. Thus, one of the fundamental aims will be reexamine the current settings of this debate. Concomitantly, the research will discuss what were the objective, historical, economic, social and cultural conditions, that allowed both the institutional rearrangement of the phonographic market as well the updating of música sertaneja to the public-consumer of genre. To illustrate the new cultural scenario of música sertaneja will be presented the case study of two duets sertanejos opponents and commercially established: Victor e Leo and Fernando e Sorocaba.
\end{abstract}

Keywords: Brazilian popular music; social history of música sertaneja; musical identity; música sertaneja universitária; phonographic industry. 


\section{SUMÁRIO}

\section{INTRODUÇÃO}

I - Uma héxis caipira: a parábola do homem Galdino

II - O “caipira tradicional”, o “caubói comercial” e o "sertanejo universitário": o mito da autenticidade na música popular brasileira

III - Notas exploratórias sobre o surgimento do movimento universitário na música sertaneja

IV - Estudo de caso e os procedimentos de análise

1. Os irmãos caipiras: a trajetória dos músicos mineiros Victor e Leo

A moda sertaneja no estilo empreendedor 56

2. A "dupla" identidade de Fernando/Sorocaba: o artista caubói e o empresário milionário da música sertaneja

"Estamos aí e vamos fazer história!” 90

3. A reinvenção do sertão brasileiro no novo cancioneiro sertanejo 104

Victor e Leo: do sertão mineiro místico ao cenário paradisíaco carioca 108

Para um amor distante? Fernando e Sorocaba levam os amigos de caminhonete para balada 118

Os retratos de uma identidade musical: o caipira Galdino e o sertanejo empreendedor 126

4. O palco é folk: o show sertanejo de Victor e Leo 
A gravação do DVD em São Paulo

Victor e Leo ao vivo e em cores

5. A balada pop sertaneja de Fernando e Sorocaba 158

Não é Barretos não! É São Paulo.. 173

\section{CONSIDERAÇÕES FINAIS}

V- Onde fica a universidade do sertão?

ANEXO A - Monitoramento da audiência radiofônica de Victor e Leo e Fernando e Sorocaba

(Ranking Crowley)

ANEXO B - Agenda musical de Victor e Leo e Fernando e Sorocaba

REFERÊNCIAS BIBLIOGRÁFICAS

Entrevistas ao autor

Filmes e documentários 200

Institutos oficiais de pesquisa 200

Programas televisivos 201

Websites acessados 201 


\section{INTRODUÇÃO}

\section{I - Uma héxis caipira: a parábola do homem Galdino}

Mesmo que a letra de Victor e Leo se rotule caipira, o produto é outro. Tenha o exemplo da alegoria do homem Galdino: se o discurso é contraditório, observe o que as mãos revelam ${ }^{5}$.

Minha maior fonte de inspiração para composição artística é o sertão. Existe um sertão místico dentro de mim ${ }^{6}$.

Para compor, eu não tenho uma fonte de inspiração única. Minhas músicas falam sobre coisas do dia a dia que podem acontecer com qualquer pessoa. Algumas são inspiradas em coisas que aconteceram comigo, outras em histórias que amigos me contam. Acredito que isso faz com que nossos fãs se identifiquem com as letras, pois muitos já passaram por situações semelhantes. A nossa preocupação é inovar sempre ${ }^{7}$.

\section{Você conhece a história do Galdino?}

Reconheço que não é usual iniciar um trabalho acadêmico com uma interrogação. Contrariando o ethos sociológico, vou introduzir meu objeto de estudo por meio de uma alegoria da héxis caipira. Em novembro de 2014, tive uma conversa com o professor de música Ivan Vilela e suas palavras finais esclareceram minhas dúvidas mais resistentes. A extensa pesquisa de campo foi encerrada apenas em janeiro de 2015, mas de antemão, tinha coletado um número suficiente de material etnográfico dos espetáculos, que prontamente, subsidiaria uma análise descritivo-comparativa dos artistas sertanejos que formavam meu quadro de estudo. Havia procurado o solícito professor para entender minimamente os instrumentos musicais usados pelos dois duetos. Não pretendia fazer uma ampla análise tímbrica, pois esse não era o objetivo proposto, porém, fazia-se útil tal descrição em uma dissertação que era estritamente sobre música. Tinha acompanhado os quatro músicos sertanejos por meses a fio em uma rotina eloquente. Procurei Vilela somente para que me

\footnotetext{
${ }^{5}$ Entrevista de Ivan Vilela ao autor, 28 de novembro de 2014.

${ }^{6}$ Entrevista de Victor Chaves ao autor, 09 de julho de 2015.

${ }^{7}$ Entrevista de Fernando Fakri de Assis “Sorocaba” ao autor, 08 de abril de 2015.
} 
relatasse as sonoridades instrumentais e as técnicas de canto que Victor e Leo e Fernando e Sorocaba apresentavam em seus shows. Gentilmente, ele assistiu a todos os vídeos e fez suas avaliações. No final da "prosa", trouxe ao violista um segundo questionamento: se os irmãos mineiros Victor e Leonardo Chaves não faziam música caipira, por que eles insistiam tanto em valorizar uma identidade musical apoiada em uma suposta autenticidade cultural? Ainda que Victor reconhecesse que: "Música sertaneja genuína vem do sertão e há pouca dela em nosso repertório", em outros momentos, o compositor asseverava ser o "herdeiro" dessa tradição: “A música caipira é a minha mãe. Então, enquanto filho dela, a música que eu fizer virá dela. Vou continuar assim"9. Embora Fernando e Sorocaba também fossem artistas nomeados como "sertanejos", os músicos apontavam pouco interesse em pormenorizar a temática: "Fazemos música sertaneja, mas temos influências do country americano e do pop. Acreditamos que essa junção de ritmos só agrega e quem ganha com isso é o público" ${ }^{10}$. Na prática, não havia um abismo que diferenciasse a produção musical entre os dois duetos, mas tampouco, existia alguma afinidade na identidade atribuída a esses cantores sertanejos que, desde 2007, têm disputado ferozmente a liderança do mercado fonográfico brasileiro. Entretanto, os afetos e também os desafetos são igualmente importantes para configuração de identidades e um indício sugestivo dos conflitos internos que configuram e acompanham as mudanças dentro do campo da produção cultural ${ }^{11}$. Em meio a essas discussões, existia ainda a problematização do sufixo "universitário" que, por si só, problematizava a investigação da pesquisa. Ainda que os quatro músicos tenham se beneficiado amplamente desse novo movimento musical, hoje ele é um termo incômodo e, até certo ponto, indesejado por eles. Apesar do antagonismo incontestável entre as duas duplas sertanejas, a resposta de Ivan Vilela seria uma bússola aos rumos do trabalho:

- Aparecido Galdino foi um vaqueiro do interior de São Paulo. Analfabeto, Galdino passou a ser um curandeiro: baixou um santo nele e começou a curar as pessoas, mas ele era católico. O padre local ficou muito enciumado, pois começou a temer romarias onde ele morava. Galdino era um vaqueiro pobre e velho. O padre era ligado ao governo militar, afeito à

\footnotetext{
${ }^{8}$ Entrevista de Victor Chaves ao autor, 09 de julho de 2015.

${ }^{9}$ Entrevista de Victor e Leo ao programa Globo Rural (Rede Globo): Novas duplas do sertanejo moderno preservam as raízes do campo, exibido em 11/01/2015.

${ }^{10}$ Entrevista de Fernando Fakri de Assis "Sorocaba" ao autor, 08 de abril de 2015.

${ }^{11}$ BOURDIEU, Pierre. Os usos do "povo". In: Coisas Ditas. São Paulo: Brasiliense, 2004. Apud: ALONSO, Gustavo. Cowboys do Asfalto: Música Sertaneja e Modernização Brasileira, 2011, p.19.
} 
ditadura, denunciou o Galdino como subversivo, então ele foi preso no DOPS e ficou quase dez anos internado em um hospital psiquiátrico. O José de Souza Martins era representante da CNBB (Confederação Nacional dos Bispos Brasileiros) diante da ditadura e tomou conhecimento do caso. A cada ano, Galdino era submetido a uma nova avaliação psiquiátrica pelo governo militar que atestava: "O que esse senhor diz com as palavras não faz sentido", isso em todos os relatórios médicos. Um dia, o José de Souza Martins foi ao encontro dele e o questionou: "Por que o senhor não saiu daqui?". Ele dizia: "Bom, todo ano, eles me perguntam se eu sou louco e eu digo que não. Mas, eles declaram que sou louco, pois estou negando a loucura. Se eu falo que sou louco, eles atestam que eu sou realmente louco do mesmo jeito". Nessa conversa, Martins percebeu que muitas vezes a fala dele não condizia com os movimentos corporais. Então, ele levou um jornalista da Folha de S.Paulo para fotografar e filmar as mãos dele enquanto era entrevistado. A partir disso, Martins elaborou um laudo técnico que libertava o Galdino, demonstrando a teoria de que o caipira, por ser oprimido, manteve uma linguagem corporal que dizia a verdade, mas com o tempo, desenvolveu uma linguagem vocal contraditória, porque ele respondia justamente aquilo que as autoridades queriam escutar. A conclusão dele faz sentido: o caipira, sendo um homem pobre, branco, porém livre, desenvolveu uma linguagem vocal que destoava da linguagem corporal. As palavras estavam em consonância com a classe dominante, mas a linguagem física não. Portanto, mesmo que a letra de Victor e Leo se rotule caipira, o produto é outro. Tenha o exemplo da alegoria do homem Galdino: se o discurso é contraditório, observe o que as mãos revelam ${ }^{12}$.

\section{II - O "caipira tradicional", o "caubói comercial" e o "sertanejo universitário": o mito da autenticidade na música popular brasileira}

\footnotetext{
A autenticidade é uma moeda de troca: "Isso é autêntico ou inautêntico!". Os grupos intelectuais e artísticos sempre foram os responsáveis por definir "o que é ou o que não é autêntico". A história de afirmações de um gênero musical é a história de lutas por afirmações, e sem sombra de dúvidas, daquilo que também é negado como expressão legítima. Essa tensão existe na história social e cultural de todos os gêneros musicais. Hoje, o mercado fonográfico é o responsável por equalizar e legitimar esse espaço de tensões ${ }^{13}$.
}

\footnotetext{
${ }^{12}$ Entrevista de Ivan Vilela ao autor, 28 de novembro de 2014.

${ }^{13}$ Entrevista do Prof. Marcos Napolitano ao autor, 07 de novembro de 2014.
} 
Embora tenha nascido em São Paulo, fui criado em uma cidade do interior paulista chamada Limeira (a 143 quilômetros da capital). Lá, não importa a faixa etária, o nível de escolaridade ou a classe social: o povo limeirense gosta de música sertaneja e ponto final. Em 2007, voltei à terra natal para iniciar os estudos acadêmicos. Na faculdade, esbarrei com alguns colegas ainda intimidados, que confessavam o gosto pela música sertaneja - não qualquer música sertaneja, mas música sertaneja universitária. No interior, escuta-se a música sertaneja (sem sufixo algum) de Victor e Leo, João Bosco e Vinícius, Maria Cecília e Rodolfo, Luan Santana, Jorge e Matheus, Fernando e Sorocaba, Paula Fernandes, César Menotti e Fabiano, Gusttavo Lima e Michel Teló, e em São Paulo também, só que com o acréscimo do termo "universitário". Então, se o artista e o gênero são os mesmos, por que diferenciá-los? Na prática, qual seria o significado dessa etiqueta "universitária" oferecida à música sertaneja? Na falta de respostas, decidi encarar a inóspita tarefa de encontrá-las, ou no mínimo, discuti-las nesta pesquisa. No entanto, notei que essa "institucionalização" simbólica não estava restrita apenas à música sertaneja. Existia o pagode universitário, o forró universitário, o axé universitário e até o funk dos morros cariocas virou funk ostentação aliás, todos esses gêneros sofrem até os dias de hoje o descrédito da crítica intelectual e artística. Em contrapartida, não existia o rock "universitário”, a MPB “universitária” e nem o samba "universitário" - afinal, esses três estilos ${ }^{14}$ musicais são consagrados pelo público tradicional, exceto o rock, que mesmo assim, foi incorporado em quase todos os ritmos brasileiros.

Nessa armadilha de rótulos, nomenclaturas e terminologias, não poderia tomar o sufixo "universitário" na música sertaneja como uma tipologia isolada de análise social. Essas categorias ditadas pelo mercado fonográfico são traiçoeiras, porque nublam a própria compreensão do conflito histórico desse fenômeno cultural. O termo "universitário" foi somente uma nova embalagem dada a esse gênero quase secular. Na realidade, ele não mudou o comportamento dos consumidores da música sertaneja, mas permitiu que uma parcela nova do público urbano pudesse admiti-la com menos constrangimento. No fim das contas, o gênero musical é o mesmo, no entanto, a apropriação entre a indústria cultural e o consumidor passou a ser mediada por esse sufixo. Nos anos 2000, os artistas se beneficiaram dessa

\footnotetext{
${ }^{14}$ Cf. estudos sobre o rock, MPB e samba: MAGI, Érica Ribeiro. "Rock and Roll é o Nosso Trabalho”: a Legião Urbana do Underground ao Mainstream. São Paulo: Editora Alameda/FAPESP, 2013; NAPOLITANO, Marcos. Seguindo a Canção: Engajamento Político e Indústria Cultural na MPB (1959-1969). São Paulo: Annablume/FAPESP, 2001; FERNANDES, Dmitri Cerboncini. A Inteligência da Música Popular: A "autenticidade" no Samba e no Choro. Tese de doutorado apresentado ao programa de pós-graduação em sociologia da Universidade de São Paulo, 2010.
} 
estratégia de marketing, porém nunca a admitiram. Não podia ser diferente: os cantores sertanejos conhecem bem o perfil socioeconômico dos seus espectadores. Eles sabem que a experiência "universitária" está longe de ser a realidade da audiência vista em seus shows. Contudo, a tarefa de nomeação é deixada a cargo dos meios de comunicação de massa ou do próprio mercado musical. Para isso, Pierre Bourdieu tem a resposta-chave: "O poder de nomear é um poder de atribuir valor simbólico. A nomeação representa um ato performativo de autoridade e legitimidade no sentido de atribuir um lugar socialmente localizado dentro do campo para esse agente" ${ }^{\prime 15}$.

Não demorou muito tempo para que o surgimento do sufixo "universitário" na música sertaneja ressuscitasse o velho "mito da autenticidade" da música popular brasileira. Marxismo e Literatura é a leitura clássica para "cutucar" tal crença. No livro, o intelectual inglês Raymond Williams discute a autenticidade cultural usando dois conceitos: a música do povo e a música para o povo ${ }^{16}$. Portanto, a música caipira seria a música do povo - uma expressão da tradição "pura" e intocada pelos interesses da indústria cultural. Por outro lado, a música sertaneja seria a música para o povo - um mero produto do mercado fonográfico para ser vendido em larga escala. Só que nenhum desses dois conceitos existe de forma "pura", porque há um jogo de apropriações entre eles. Esse embate de polarizações é um problema geracional da música sertaneja ${ }^{17}$. Foi transmitido de geração em geração em quase um século de história social do gênero. Então, vamos usar o sufixo "universitário" e pensá-lo nos termos de Raymond Williams: a música universitária é feita por universitários dentro da universidade, ou no mínimo, ela é feita sob a chancela do campo universitário que vai definila como autêntica ou inautêntica. Entretanto, existe a música universitária feita para os universitários, ou seja, universitários de uma nova classe-média social emergente - um estrato populacional recém-chegado à instituição universitária, que é, ao mesmo tempo, o públicoconsumidor dessa música. Qual seria o ponto-chave: pensar a diferença entre o forró

\footnotetext{
${ }^{15}$ BOURDIEU. Pierre. O Poder Simbólico. Bertrand Brasil: Rio de Janeiro, 1989, p.146.

${ }^{16}$ WILLIAMS, Raymond. Marxismo e Literatura. Rio de Janeiro: Zahar, 1979, p. 57. Nota: o conceito original do autor é para literatura, mas aqui foi adaptado à música.

171929 a 1940: música caipira ou música sertaneja de raiz; 1950 a 1980: música sertaneja moderna; 1990: música sertaneja romântica; 2000: música sertaneja universitária ou nova música sertaneja. Em um primeiro momento, vários artistas dessas gerações foram acusados de serem "músicos comerciais" por não louvarem a tradição "autêntica" da música caipira. Depois de se legitimarem no mercado fonográfico, quase todos tentaram uma reaproximação com esse movimento de valorização do cancioneiro tradicional. Cf. ALONSO, Gustavo. Cowboys do Asfalto: Música Sertaneja e Modernização Brasileira, 2011; OLIVEIRA, Allan de Paula. Miguilim Foi pra Cidade ser Cantor: Uma Antropologia da Música Sertaneja, 2009.
} 
universitário e o sertanejo universitário. Nos anos 1990, o forró "universitário" foi uma reação contra o forró voltado para o mercado fonográfico. Foi um movimento de apelo ao autêntico contra uma suposta "deturpação da pureza" do forró. Você teria o forró autêntico do Luiz Gonzaga e você teria uma apropriação indevida desse gênero para fins meramente comerciais. E o que foi o forró universitário? Foi um forró feito por jovens que estavam dentro da universidade e que foram fazer forró como os mestres tradicionais faziam. Isso não é uma música para universitários, mas uma música de universitários - aqui, o selo "universitário" é o carimbo legitimador da autenticidade e da originalidade da raiz, claro que apenas no plano do discurso.

Então, de 2005 para cá, o que reivindicam os artistas da música sertaneja universitária? Os novos músicos não têm a pretensão de fazer sertanejo universitário, no sentido de recuperação ou de resgate cultural $^{18}$ - eles fazem música sertaneja para universitários. Nesse caso, houve uma mudança: a universidade não é mais um espaço de legitimidade intelectual e deixou de ser uma garantia de autenticidade simbólica como foi para o forró universitário, mesmo que isso fosse falso, e passou a ser simplesmente um mercado - o sertanejo universitário é um mercado para universitários. Tudo isso dá sentido a esse jogo de diferenciação musical promovido pelos novos artistas do gênero. Em pouco tempo, eles abriram mão do legado melodramático deixado pelos ícones do sertanejo romântico dos anos 1990. Hoje, a nova aposta do cancioneiro sertanejo está voltada à farra e à diversão ${ }^{19}$, ou seja, temáticas que estão diretamente ligadas aos circuitos profissionais das baladas universitárias e aos subcircuitos tradicionais das festas do peão de boiadeiro. Talvez, isso explique também essa nova apropriação corporal que o mercado fonográfico tem exigido dos músicos sertanejos recém-ingressos na carreira artística. Dentro e fora dos palcos, nota-se toda uma atmosfera de apelo ao prazer sexual. Existe algo mais ostensivo na forma como se vestem, no sentido de vender a imagem de um corpo pronto para o prazer. E esse corpo é o porta-voz da música que vai embalar o prazer daqueles que podem se sentir universitários, afinal de contas, chegaram à classe-média e agora eles têm um álibi para celebração do prazer, apoiado por uma indústria que financia essa balada universitária sertaneja. E o que o termo "universitário" tem a ver com isso? A história da música popular brasileira é a história dos deslocamentos de sentidos e de atribuições desse conceito de "universitário" - primeiro no

\footnotetext{
${ }^{18} \mathrm{O}$ compositor Victor Chaves foi um dos poucos defensores sinceros da preservação de tal tradição.

${ }^{19} \mathrm{Na}$ contramão, Victor e Leo foram os únicos que não seguiram esse roteiro.
} 
espaço onde ela é feita, depois como chancela intelectual e por último como um espaço puramente configurado para fins mercadológicos. Nos primórdios, a MPB também se dizia "universitária", pois era uma música feita na universidade e por universitários, pelo menos geograficamente. Nos anos 1960 e 1970, a música caipira foi abraçada por essa mesma MPB "universitária" e pelas esquerdas do nacional-popular ${ }^{20}$. No entanto, com o tempo, houve um enfraquecimento desses critérios de hierarquização do gosto social que a MPB perscrutou. Por outro lado, verificou-se também um desgaste na construção de novos conceitos de legitimidade que, nos dias de hoje, passam intermitentemente pelo aval do mercado e, consequentemente, pelos grupos de poder aquisitivo: "Na atualidade, você passa a ter o mesmo poder aquisitivo ou semelhante, pois o mercado equalizou essas tensões sociais" ${ }^{21}$. Se esse sertão "puro" ou essa figura "autêntica" do caipira/sertanejo existiram algum dia, existiram apenas dentro da universidade ou no imaginário afetivo dos intelectuais e artistas ligados a ela ${ }^{22}$. Não foi à toa que o próprio termo caipira foi sistematizado dentro da universidade $^{23}$. Entretanto, esse sertão da universidade não existe mais. Hoje, o sertão foi institucionalizado, não pela universidade, mas pelos empresários, artistas empreendedores, escritórios comerciais e gravadoras nacionais e multinacionais que compõem a indústria fonográfica desse gênero musical. Lá, esse sertão foi instrumentalizado e transformado na universidade do sertão - uma instituição técnica e capitalista voltada ao lucro e destinada a vender um sertão estritamente mercadológico.

Em 1929, a primeira gravação em disco da música caipira/sertaneja foi articulada por Cornélio Pires. O folclorista foi o responsável por gravar 47 discos contendo as modas de

\footnotetext{
${ }^{20}$ Cf. NAPOLITANO, Marcos. A Síncope das Ideias: A Questão da Tradição na Música Popular Brasileira. São Paulo: Editora da Fundação Perseu Abramo, 2007; RIDENTI, Marcelo. Em Busca do Povo Brasileiro: Artistas da Revolução, do CPC à Era da TV. Rio de Janeiro: Record, 2000.

${ }^{21}$ Entrevista do Prof. Marcos Napolitano ao autor, 07 de novembro de 2014.

22 "É claro que a música caipira sempre fez parte do imaginário popular, mas talvez ela não fosse o epicentro desse imaginário se comparada com o samba e outros gêneros musicais nordestinos até os anos de 1950. O caipira ficou com uma contribuição residual nesse imaginário nacional popular. É como se fosse uma espécie de cultura local, restrita e sem pontos de contatos. Foi por meio da sociologia de Antonio Candido que ele é resgatado dos bairros rurais e surge como objeto acadêmico", Prof. Marcos Napolitano ao autor, 07 de novembro de 2014.

${ }^{23}$ Segundo o historiador Gustavo Alonso, a primeira vez que o termo "caipira" foi apresentado de forma sistêmica por um acadêmico brasileiro foi na obra do sociólogo Antonio Candido, no livro Os Parceiros do Rio Bonito: Estudo Sobre o Caipira Paulista e a Transformação dos Seus Meios de Vida (1964). A obra contribuiu para o estudo do universo rural brasileiro e influenciou uma geração de pesquisadores na temática. Em Parceiros do Rio Bonito, Candido deu ao termo "caipira" sentido teórico e singular sem associá-lo ao termo "sertanejo" (Ibidem, p.163).
} 
viola. Desde então, essa tradição na música sertaneja tem sido uma tradição forjada por disputas históricas no campo da música popular brasileira. Por esse motivo, discutirei nos próximos capítulos, o modo como as duas duplas estudadas se relacionam com tal tradição cultural e os diversos modos como ela é herdada. Mesmo os dois duetos sertanejos estando no polo comercial, eles se alimentam dessa disputa contínua pelo mito da autenticidade. Para Fernando e Sorocaba, a via de legitimação é a comercial e, para Victor e Leo, é a sofisticação musical. No passado, o peso do apoio tradicional já foi maior, mas ainda sim, é válido para músicos como Victor Chaves. O compositor mineiro gosta de flertar com o estilo caipira lírico, aliás, ele é o único exemplar desse caipira lírico existente na nova geração da música sertaneja comercial. Victor nunca prometeu ser um músico caipira, embora esse legado lhe sirva como diferenciador comercial. O seu irmão caçula, o cantor Leonardo Chaves aceitou sem hesitar a repaginação pop exigida pelo escritório Som Livre. Já Sorocaba usa a referência da tradição do sertanejo romântico dos anos 1990, ou seja, a inovação tecnológica. O artistaempresário instrumentalizou a música sertaneja e agora quer comandar os rumos do mercado fonográfico. Dito tudo isso, o sufixo "universitário" deve ser lido como um mero marcador mercadológico e não como um definidor musical-estético desses novos artistas. Portanto, sugiro a denominação genérica de nova música sertaneja para análise sociológica.

\section{III - Notas exploratórias sobre o surgimento do movimento universitário na música sertaneja}

A onda do chamado sertanejo universitário dava claros sinais de vitalidade ascendente. O novo sertanejo, surgido por volta de 2005, parecia claramente ter tomado o país em pouco tempo. Artistas universitários estavam sempre entre as listas das canções mais tocadas do ECAD e programas de televisão e novelas tocavam constantemente músicas de Victor \& Leo, João Bosco \& Vinícius, Maria Cecília \& Rodolfo, Luan Santana, Jorge \& Matheus, Fernando \& Sorocaba, Paula Fernandes, César Menotti \& Fabiano, etc. Não obstante, a aparente identidade comum, o sufixo universitário causava polêmicas, acusações e divergências, mesmo entre os próprios artistas sertanejos. Mas isso não impedia que o gênero seguisse conquistando plateias crescentes ${ }^{24}$.

$\mathrm{Na}$ escassez de estudos acadêmicos que abordem sistematicamente essa atualização do gênero, reuni alguns depoimentos que discutam o surgimento do sertanejo universitário. Não

\footnotetext{
${ }^{24}$ ALONSO, Gustavo. Cowboys do Asfalto: Música Sertaneja e Modernização Brasileira, 2011, p.159.
} 
existe um consenso bibliográfico ou documental que aponte a origem da institucionalização "universitária" na música sertaneja. Tudo indica que até o próprio termo traduza mais os anseios da indústria fonográfica do que uma nova definição estética da música sertaneja. A partir dos anos 2000, o movimento universitário passou a anunciar tanto aos produtores quanto aos consumidores da música sertaneja um novo produto, que não estava mais envolvido com o passado conflituoso do gênero e que agora encontraria novos espaços de sociabilidade, entre eles, as universidades brasileiras. Os principais precursores da vertente universitária foram os músicos João Bosco e Vinícius (Mato Grosso do Sul) e César Menotti e Fabiano (Minas Gerais). Eles foram os responsáveis pela divulgação dessa nova música sertaneja e a levaram para o resto do Brasil, principalmente às festas universitárias. Hoje, os próprios não se intitulam mais como universitários. Eles alegam que não faz mais sentido o termo às suas carreiras, apesar de terem sido os "mentores" desse novo estilo. Porém, reconhecem que a temática mudou ${ }^{25}$. A linguagem musical do sertanejo manteve seu universo romântico, mas agora embalando as animadas festas dentro e fora das universidades. Gradualmente, o estilo perdeu o bucolismo da música caipira dita tradicional e o romantismo rasgado que o impulsionou na década de 1990. Hoje, a música sertaneja incorpora influências do axé baiano, do pop rock dos anos 1980, da música eletrônica e até do pancadão baiano chamado de arrocha. "Esse terremoto que arrancou o gênero das entranhas interioranas do país para fazê-lo aflorar nas metrópoles tem nome, inclusive: sertanejo universitário - que é como se batizou a acelerada radical que duplas como César Menotti e Fabiano e João Bosco e Vinícius imprimiram às baladas românticas a partir de 2003. Com o ritmo mais rápido e percussivo, o sertanejo roubou sem piedade o público do pop rock"26.

Há pouca concordância de que seus nomes estejam ligados a esse sufixo - entre os artistas pioneiros do movimento ou aqueles beneficiados por ele. Logo depois que o novo sertanejo teve seu boom comercial e o termo se tornou popular, rapidamente passou a ser usado de forma depreciativa entre os críticos e parcela do público tradicional, num sentido comum de "eu gosto de sertanejo, não ouço esse negócio de universitário aí". Aos olhos

\footnotetext{
25 “(1) uma poética amorosa otimista, na qual os amantes querem efetivar seus sentimentos amorosos e o tom da canção é otimista. Trata-se da "poética do amor afirmativo"; (2) em segundo lugar, estão as canções que favorecem encontros fortuitos e breves em festas. Trata-se da "poética da farra"; (3) caso não haja correspondência entre os amantes, na lógica rápida dos amores furtivos, impera a lógica do "tô nem aí", ou seja, não se sofre mais por amor e parte-se para outros relacionamentos aparentemente sem culpas. Essa é a "poética do "tô nem aí". Somadas as três propostas, percebe-se que, ao menos tematicamente, houve uma mudança de 180 graus no sertanejo universitário" (ALONSO, 2011, p.439).
}

${ }^{26}$ Reportagem: Sérgio Martins. Fonte: Revista Veja: O Brasil virou sertão, p.91, 30/01/2013. 
desses artistas, o sufixo também foi visto como algo menor e vulgar para rotulá-los. Em 2016, é até possível algum distanciamento histórico para compreender toda aquela geração dos anos 2000 e a origem desse novo movimento na música sertaneja, mas ser chamado de universitário ninguém quer. Mesmo porque, para muitos duetos, como é o caso de Victor e Leo, não fazia e nem faz sentido algum chamá-los de "sertanejos universitários". Esse termo foi simplesmente um rótulo comercial usado para vender um "novo" produto, ou melhor, uma "nova" embalagem, cujo rótulo dizia: "olha, eu toco sertanejo universitário, não aquele sertanejo velho, triste e antigo que seu pai ouvia". Muitos artistas usaram esse lema e depois tiveram que arcar com os ônus, principalmente com as críticas dos sertanejos veteranos. $\mathrm{Na}$ realidade, foi mais uma estratégia de diferenciação marqueteira do que propriamente um movimento musical que ficará registrado na história social do gênero. Por volta de 2005, período no qual o sertanejo universitário estava em evidência, talvez até fosse uma música consumida por estudantes universitários sim. Entretanto, era um público muito específico e residual dentro do gênero: "Esse sertanejo que a gente pode chamar de novo, de dez anos para cá, ele não teve tanta facilidade de sair do nicho da molecada (molecada quando digo é da universidade). João Bosco e Vinicius, por exemplo, eram dois estudantes universitários que cantavam em festas de faculdades, nos cursos de agronomia e zootecnia. Tudo girava em torno da faculdade e o nome não provém do acaso" ${ }^{27}$. No entanto, depois que o movimento universitário começou a se encorpar, os novos sertanejos foram se adaptando às exigências mercadológicas, justamente para atender um público-consumidor mais abrangente e sem relação alguma com o sistema de ensino superior: "Estes artistas penaram muito tempo até conseguirem outros espectadores" ${ }^{\prime 28}$.

Victor e Leo e Fernando e Sorocaba também nunca assumiram o "título universitário": "Não é que me incomoda, apenas não carregamos esse sufixo. Começamos a criar nosso estilo há 23 anos. Não dá para aceitar um rótulo que alguém resolveu nos impor com anos e anos de estrada. Até tentaram chamar o nosso som de sertanejo universitário, porque era algo novo e

\footnotetext{
${ }^{27}$ Entrevista de André Piunti ao autor, 22 de novembro de 2014. André Piunti foi pioneiro na divulgação da música sertaneja dentro do jornalismo digital. Em 2007, foi o autor do blog Universo Sertanejo, reservado exclusivamente ao gênero. Entre 2009 e 2014, o site fez parte do portal UOL. Em 2010, André estreou o programa Universo Sertanejo na Rádio UOL, e o Cowboy Nativa na rádio Nativa FM, ambos no ar. No ano de 2014, assinou o roteiro e foi responsável pelo conteúdo histórico do Bem Sertanejo, quadro apresentado por Michel Teló no Fantástico (exibido pela Rede Globo). Em 2015, ao lado de Teló, lançou o livro Bem Sertanejo, com histórias registradas durante as gravações da série. É também autor dos livros Música Sertaneja - Uma Paixão Brasileira (volumes um e dois).

${ }^{28}$ Entrevista de André Piunti ao autor, 22 de novembro de 2014.
} 
que atraía gente de todos os gostos e idades. Mas negamos o rótulo, uma vez que isso limitava o quão expansivo era nosso estilo. Outros tomaram para si a ideia e assim foi. Nunca falamos sobre isso com nenhum colega" ${ }^{\text {29 }}$. Por outro lado, Fernando e Sorocaba não apontam tanta indisposição quanto a primeira dupla: "Não gosto de rótulos, mas acredito que essa nova geração da música sertaneja se aproximou das baladas das grandes cidades, caindo no gosto dos jovens urbanos. O sertanejo sempre terá sua raiz no campo e nas áreas rurais, pois é onde ele nasceu, mas ultrapassar essa barreira e chegar à 'cidade grande' é uma conquista muito importante" ${ }^{\prime 30}$. Para o empresário-artista, é claro que a linguagem mudou e está com um papo mais jovem e descontraído, porém, "o amor ainda continua sendo um tema unânime dentro da música sertaneja"31.

Houve também inovações instrumentais e técnicas no sertanejo universitário em relação à música sertaneja dos anos 1990. A guitarra foi praticamente deixada de lado, sendo substituída pelo violão em cordas de aço. O teclado, que sempre esteve presente na década anterior, foi trocado rapidamente pelo acordeon. Em geral, a bateria ficou mais intensa e com graves mais enfatizados. O andamento musical ganhou um ritmo mais acelerado e a sonoridade se tornou mais acústica também ${ }^{32}$. Inclusive, o formato acústico teve um peso central na carreira dos músicos universitários. No sertanejo romântico dos anos 1990, esse padrão acústico, com discos gravados na presença do público ao vivo, não fazia parte da realidade do gênero. O primeiro acústico sertanejo foi gravado somente em 1998 pela dupla Chrystian e Ralf e depois foi retomado por Bruno e Marrone em 2001. Desde então, os shows acústicos e ao vivo se popularizaram no gosto do público e dos artistas sertanejas:

Para que o formato tomasse de vez a seara sertaneja foi preciso o estouro do disco pirata de Bruno e Marrone em 1999. Nele, Bruno e Marrone cantavam apenas ao som de violão em um modelo de gravação bastante simples. Comercializado ilegalmente, foi esse disco de Bruno e Marrone que emplacou de vez o formato acústico no gênero sertanejo. O curioso é que os sertanejos dos anos 90 aparentemente não se conscientizaram dessa mudança. Nem mesmo Bruno e Marrone fizeram outro acústico até o advento dos universitários. Foram os universitários que gostaram da ideia do disco acústico e usaram e abusaram dessa proposta estética. João Bosco e Vinícius, César Menotti e Fabiano, Jorge e Mateus, Victor e Leo: todos eles lançaram discos na estética acústica na pré-história do gênero, entre 2001 e 2005, ajudando a formatar esse novo estilo ${ }^{33}$.

\footnotetext{
${ }^{29}$ Entrevista de Victor Chaves ao autor, 09 de julho de 2015.

${ }^{30}$ Entrevista de Fernando Fakri de Assis "Sorocaba" ao autor, 08 de abril de 2015.

${ }^{31}$ Entrevista de Fernando Fakri de Assis "Sorocaba" ao autor, 08 de abril de 2015.

${ }^{32}$ ALONSO, 2011, p.445-446.

${ }^{33}$ ALONSO, 2011, p.447.
} 
Os shows ao vivo e a gravação dos DVD's acústicos são os carros-chefes do gênero. É por meio desses dois formatos fonográficos que os artistas obtêm lucros extraordinários, lotando estádios com plateias numerosas. Antes do reconhecimento nacional, Victor e Leo produziram três álbuns: o primeiro em 2002, pela extinta gravadora Number One; depois, dois discos independentes: Vida Boa (2003) e Victor \& Leo Ao Vivo (2005). Esse último CD espalhou-se por diversas regiões e teve mais de dois milhões de cópias pirateadas. Em junho de 2007, a gravadora Sony-BMG contratou os músicos e passou a distribuir oficialmente o CD Victor e Leo Ao Vivo, modificando somente a capa original. No mesmo ano, a dupla gravou o quarto CD e o primeiro DVD da carreira: Ao Vivo em Uberlândia. Na gravação, é visível a emoção dos irmãos: “Gravar o primeiro DVD, em 2007, foi como provar de um chocolate pela primeira vez: eu me empanturrei. Tive muito prazer, mas passei um pouco mal depois, foi tudo exagerado. Muitos shows, muitas entrevistas. Hoje, eu sei dosar melhor a medida desse chocolate" ${ }^{34}$. Em janeiro de 2015, acompanhei a gravação do quarto DVD na carreira dos músicos, o DVD Ao Vivo Irmãos ${ }^{35}$.

No começo dos anos 2000, uma parcela dos artistas sertanejos se beneficiou da produção pirata. O sertanejo foi um dos primeiros gêneros, atrás somente dos ritmos nordestinos, a perceber que as gravadoras já não eram mais tão indispensáveis para o sucesso comercial. O barateamento dos componentes de tecnologia permitiu que os artistas produzissem e custeassem seus próprios discos. Estava mais acessível também a compra de gravadores de CD's nos computadores domésticos. O músico sertanejo entendeu essa nova lógica fonográfica e tomou o mercado das gravadoras para si. Nos shows, os próprios artistas distribuiriam gratuitamente os CD's piratas. O gênero sempre teve público e renda econômica garantida com os shows espalhados pelo Brasil, de modo que abrir mão do dinheiro da venda dos discos não foi um impedimento para a manutenção do sucesso. Todavia, esse rearranjo no mercado fonográfico não teve a adesão de todos os artistas. Tomemos o exemplo combatível de Victor e Leo: "Durante os anos iniciais de trabalho nacional, nossos CD's eram muito pirateados. Certos artistas começaram a fabricar e a distribuir seus CD's gratuitamente, inclusive nas bilheterias dos próprios shows. Então, o próprio pirateiro quebrou, uma vez que o artista que ele piratearia dava seu produto" ${ }^{36}$. Victor Chaves então sugere qual foi a receita

\footnotetext{
${ }^{34}$ Revista Quem: Victor e Leo sobre DVD: "No primeiro foi tudo exagerado”, 04/07/2015.

${ }^{35}$ Cf. Capítulo 4.

${ }^{36}$ Entrevista de Victor Chaves ao autor, 09 de julho de 2015.
} 
de sucesso usada pela dupla: "Se deu pela qualidade da música, pois isso fez com que as pessoas quisessem compartilhar a emoção causada. Os modismos, que dependem de plataformas, logo passam e as plataformas também"37.

Logo, as gravadoras aceitaram uma posição menos mandatária na administração da carreira dos músicos. No entanto, não são totalmente indispensáveis: elas ainda mantêm o prestígio dos artistas, devido às suas credenciais e aos relacionamentos midiáticos com a televisão e o rádio. O Grupo Som Livre (Organizações Globo), por exemplo, tem acesso às trilhas sonoras das novelas ${ }^{38}$ e aos programas televisivos de altos índices de audiência da emissora carioca Rede Globo, além disso, estampa a rotina dos músicos nas páginas da revista Quem ou no portal de notícias Ego e também projeta seu elenco aos principais clientes da publicidade e da propaganda brasileira. De qualquer forma, hoje é muito difícil que uma dupla sertaneja não aceite uma gravadora, mesmo que seja apenas uma parceria. Elas podem não ter mais tamanha centralidade, porém, são instituições que promovem acessos que seriam praticamente impossíveis às redes de sociabilidade de um único artista. Victor e Leo sabem disso. Em 2013, deixaram os estúdios da gravadora Sony-BMG e foram para o escritório da Som Livre: "A Sony é uma grande gravadora, com excelentes profissionais e só tivemos momentos de êxito e satisfação lá. Contudo, a Som Livre brigou forte para nos levar, inclusive financeiramente. Então, era hora de mudarmos um pouco de formato e enveredarmos por um caminho em que havia gente nova, querendo muito nosso catálogo e que tem um potencial de divulgação muito poderoso por trás"39. Sorocaba foi mais empreendedor: em 2014, não renovou contrato com o selo Som Livre e tomou conta do seu próprio escritório: FS Produções Artísticas: “A música sertaneja é um bom negócio. O sertanejo sempre esteve em alta e, hoje, ele está muito mais atuante, porque conseguiu atingir todas as classes sociais" $" 40$.

Tanto a estabilidade econômica quanto o sucesso comercial que promovem a carreira dos novos músicos sertanejos provêm, quase que exclusivamente, das apresentações ao vivo.

\footnotetext{
${ }^{37}$ Entrevista de Victor Chaves ao autor, 09 de julho de 2015.

38 “A divulgação em trilhas sonoras novelísticas contribuiu e sempre contribuirá. Inclusive para os tempos de hoje. Todo vetor para nossa arte contribui, ainda mais quando há uma história bem contada para que a canção sirva de fundo", Victor Chaves. Fonte: do autor (2015).

${ }^{39}$ Entrevista de Victor Chaves ao autor, 09 de julho de 2015.

${ }^{40}$ Entrevista de Fernando Fakri de Assis "Sorocaba" ao autor, 08 de abril de 2015.
} 
O produtor musical Marcos Mioto fez as contas: os dez principais artistas sertanejos fazem cerca de 180 shows ao ano, com média de dez mil pessoas por espetáculos. São aproximadamente 18 milhões de espectadores ao ano. Cada show é vendido por volta de R\$ 175 mil, ou seja, apenas os dez principais artistas sertanejos movimentam mais de R $\$ 315$ milhões por ano no mercado do show business brasileiro. Dez anos atrás eram cinco shows sertanejos para cinco de outros estilos. Hoje, para cada dez shows, oito são sertanejos ${ }^{41}$. Nossos retratados estão incluídos nessa lista, mas com um cachê um pouco maior: Victor e Leo recebem R\$ 180 mil $^{42}$ por apresentação, mas no passado, o valor foi superior a esse. Ultimamente, eles têm feito menos shows, contudo mantêm a rentabilidade alta (grande vendagem de CD's e DVD's, arrecadação de direitos autorais e também por meio da publicidade). O preço do show de Fernando e Sorocaba é ainda mais caro: entre R $\$ 200 \mathrm{mil}^{43}$ a $\mathrm{R} \$ 350 \mathrm{mil}^{44}$ (os investimentos robustos em novas tecnologias digitais e nos artefatos cênicos justificam o preço salgado de suas megaproduções). Não há dúvidas: os artistas sertanejos ganham dinheiro mesmo com as apresentações e shows ao vivo espalhados por todo o Brasil - do interior às capitais, dos subúrbios às megacasas de espetáculos.

O interior do Brasil ainda tem um peso significativo na carreira dos sertanejos. Mesmo que alguns não sejam reconhecidos nas grandes capitais, os músicos sobrevivem com grande força no interior do país. Quando se chega à capital de São Paulo, é porque a dupla está bemcotada e isso representa um claro sinal de que os artistas já estão consagrados em quase todos os espaços fonográficos do país. Foi assim com Fernando e Sorocaba, em Londrina (Paraná), e para Victor e Leo, em Uberlândia (Minas Gerais). Em Goiânia, por exemplo, é muito comum e é mais fácil ser conhecido, porque o consumo de música sertaneja é muito maior, assim como em Minas Gerais, enfim, estados mais sertanejos: "São Paulo não é uma capital só sertaneja, pois tem uma concorrência muito grande. Então, quando eles conseguem maior destaque em São Paulo é porque realmente existe um forte investimento por trás deles" ${ }^{\text {" }}$. Gradualmente, desde os anos 1990, o gênero vem conquistando plateias das grandes

\footnotetext{
${ }^{41}$ Fantástico (Rede Globo): Michel Teló mostra negócio milionário que a música sertaneja movimenta, exibido em 19/10/2014.

${ }^{42}$ Portal R7: Descubra quanto custa o cachê dos cantores famosos, 26/06/2014.

${ }^{43}$ Portal R7: Descubra quanto custa o cachê dos cantores famosos, 26/06/2014.

${ }^{44}$ Extra/Globo: Jorge e Mateus mantêm cachê mais alto há mais de um ano; E Lucas Lucco teve aumento de $100 \%$. Saiba quanto ganham os sertanejos, 07/08/2015.

${ }^{45}$ Entrevista de André Piunti ao autor, 22 de novembro de 2014.
} 
metrópoles $^{46}$. São Paulo aceitou o sertanejo após o sucesso de Chitãozinho e Xororó, Zezé Di Camargo e Luciano, Leandro e Leonardo e João Paulo e Daniel. A partir de 2005, o sertanejo universitário também passou a fazer parte dos redutos boêmios de São Paulo ${ }^{47}$. Bares noturnos e casas de espetáculos, localizadas nos bairros nobres da cidade, incluíram o novo sertanejo à balada paulistana ${ }^{48}$. No entanto, esse novo perfil de consumidor não é um acontecimento apenas limitado à cidade de São Paulo - o Brasil é sertanejo ${ }^{49}$ :

O sertanejo já foi considerado um gênero menor. Hoje não é mais assim, nem de longe. Segundo uma pesquisa da Target Group Index, 47\% dos brasileiros que escutam rádio o fazem para ouvir música sertaneja. E a maioria desses ouvintes está dividida entre as classes A e B (36\%) e C (52\%). Não espanta que o gênero domine as preferências do público em São Paulo e seu interior (60\% e 61\%), ou mesmo em Brasília (56\%). Mas é assombroso que responda por $45 \%$ delas em Salvador. O sertanejo já é o terceiro gênero mais popular na capital baiana. A música sertaneja é também campeã de execução. Segundo a Crowley Broadcast Analysis, empresa que afere a audiência das rádios, das vinte canções mais executadas no país em 2012, onze delas são músicas sertanejas ${ }^{50}$.

O sucesso econômico do agrobusiness tem sido fundamental à nova geração da música sertaneja. Esse setor propaga uma cultura de prosperidade da agropecuária moderna, que é imensa no interior do Brasil. O agronegócio e seus subcircuitos culturais são os principais mantenedores econômicos desse gênero até hoje. Os artistas sabem bem disso. Nas palavras de Sorocaba: "As feiras agropecuárias e as festas do peão do boiadeiro são extremamente importantes. É por meio desses espaços que o nosso trabalho percorre todo o território brasileiro",51. Para os irmãos Chaves: "São palcos que dão continuidade ao nosso trabalho por todo o país" "52. O violista e professor Ivan Vilela acrescenta: "Estive em Goiás e é impressionante o tamanho da força que tem esse interior brasileiro. Até brinco: o sertanejo

\footnotetext{
${ }^{46}$ A pesquisa Tribos musicais - o comportamento dos ouvintes de rádio sob uma nova ótica realizada entre 2012 e 2013 pelo IBOPE (Instituto Brasileiro de Opinião Pública e Estatística) revelou que a maior parte do público sertanejo pertence à classe $\mathrm{C}$, está no Centro-Sul, tem entre 25 e 34 anos e nível escolar fundamental. Aliás, $65 \%$ da audiência radiofônica brasileira é basicamente sertaneja.

47 “O sertanejo invade São Paulo. Percebe-se que esse ambiente agora pode veicular o gênero. O sertanejo começa a ter um papo um pouco mais descolado também, como Michel Teló com Aí Se Eu Te Pego, e Gustavo Lima com Tererêe - deixa de ser brega e vira cool', André Piunti. Fonte: do autor (2014).

${ }^{48}$ Woods, Villa Mix e Brooks comportam entre 800, 1000 e 1200 pessoas.

${ }^{49}$ Revista Época/Globo: O Brasil é sertanejo, 01/11/2013.

${ }^{50}$ Revista Veja: O Brasil virou sertão, p.89-90, 30/01/2013.

${ }^{51}$ Idem, 08 de abril de 2015.

${ }^{52}$ Idem, 09 de julho de 2015.
} 
romântico saiu de Goiás, os universitários de Campo Grande e agora estamos esperando o que virá do Tocantins" ${ }^{\text {53 }}$. O êxito do agronegócio brasileiro foi muito importante para reprodução da filosofia de "prosperidade rural" vinda do campo norte-americano - de um campo moderno e tecnológico voltado para o urbano. Um interior agrícola que, hoje, tem todas as comodidades de uma metrópole urbana: "Não é nada de roça, é nível de exportação. Esse circuito gera muito dinheiro. O que consegue manter a música sertaneja ascendente é vitamina, quer dizer, dinheiro. Os shows e eventos do agronegócio constroem as carreiras dos novos artistas. E o público desse negócio é essa classe-média emergente. Uma classe com poder aquisitivo muito grande, mas com pouco capital escolar e cultural"54.

O sufixo "universitário" funcionou como uma espécie de alegoria das mudanças econômicas, sociais e culturais promovidas no Brasil nos últimos quinze anos. A consolidação desse novo sertanejo faz parte de um processo social mais abrangente, que envolve a formação de uma nova classe-média brasileira e de um novo público-consumidor. Uma audiência predominantemente jovem e urbanizada que passa a ter mais acesso ao sistema universitário, ou pelo menos, coexiste com uma cultura acadêmica. De acordo com o historiador Marcos Napolitano, o mercado sinaliza com tais sufixos um convite de "venha" para uma classe-média endinheirada com capital econômico, mas com pouco capital cultural. Em contrapartida, a classe-média mais intelectualizada e com capital cultural faz exatamente o contrário: vai procurar o funk, funk de palavrão, ou aquele sertanejo precário, enquanto técnica de produção. Na verdade, esses sufixos podem ser vistos meramente como nichos de mercado, pois os próprios artistas não transitam por meios universitários e, por isso, eles próprios não usam tal rótulo: "Isso [o sufixo] é a forma da indústria e de uma crítica musical de mídia massiva para fugir de conceitos anteriores de classe. E tem um nível de produção, não dos artistas, mas dos produtores e empresários de criarem esses nichos. Cria-se um circuito que 'pega' e pronto" ${ }^{, 55}$. Nos últimos quinze anos, a internet tem reconfigurado, quase que por completo, todos os gêneros musicais, principalmente por meio das redes sociais. $\mathrm{O}$ uso de redes sociais praticamente solapou a hierarquia existente anteriormente entre o artista e o público. Hoje, determinada sociabilidade está presente virtualmente na internet até mais do fisicamente.

\footnotetext{
${ }^{53}$ Entrevista de Ivan Vilela ao autor, 28 de novembro de 2014.

${ }^{54}$ Entrevista de Ivan Vilela ao autor, 28 de novembro de 2014.

${ }^{55}$ Entrevista do Prof. Marcos Napolitano ao autor, 07 de novembro de 2014.
} 
O êxito comercial da música sertaneja trouxe incômodo aos artistas dos outros gêneros nacionais. Para o cantor Guilherme Arantes, herdeiro da MPB dos anos 1980, a existência desse cenário de balada no Brasil atesta a infantilidade do país e a perda da profundidade social: "É uma coisa rasa, é só festa. É só sertanejo e pagode. É só cana, laranja e boi. O Brasil emburreceu devido à monocultura. Foi uma inserção no mercado de uma massa de excluídos. São goianos, são sertanejos, é o mundo da agromúsica. Houve essa inclusão das festas populares. Existe a ascensão de uma classe-média negra, que é quando surge o pagode; da classe-média baiana, que dá no axé; de Goiânia, com o sertanejo; e agora com o Pará"56. O roqueiro Nando Reis segue o mesmo tom de desdém: "Muitos desses trabalhos não me interessam muito. O que mais me incomoda nesse estilo sertanejo é certa pobreza na forma de escrever. Acho que as letras do sertanejo são muito pouco desenvolvidas. É um grau de chavão e isso eu acho triste" esse sertanojo 'universotário' [sic] é uma demência. Você pode até gostar, mas come cocô. Isso é cocô para se comer" ${ }^{2}$. O radicalismo crítico contra a música sertaneja foi amenizado pelo violista Renato Teixeira: "Temos que ter paciência para que o conteúdo possa melhorar. Mais para frente, essa música [sertaneja] vai fazer surgir artistas tão poderosos como os que a MPB produziu em sua fase áurea. Hoje, a música do interior domina, conquista multidões, mas as pessoas ficam deslumbradas, os espetáculos interessam mais do que o conteúdo"59. Segundo o compositor de Romaria, daqui em diante iniciará um processo de decantação, que fará com que só os grandes nomes fiquem: "Por exemplo, o Victor Chaves é um cara que veio para ficar. Ele não é um compositor banal" ${ }^{\prime 60}$. Entretanto, o atual status da música sertaneja é também reprovado pelos próprios artistas do gênero. Em 2012, Jorge Barcelos (da dupla Jorge e Mateus) fez duros ataques às rixas entre as duplas, escritórios e empresários: "O mercado da música sertaneja é podre! Onde já se viu essa competição que acontece hoje entre duplas, entre escritórios? Nossas carreiras não são um jogo, ninguém está competindo, ninguém vai ser campeão no fim do ano se fizer mais pontos. As pessoas estão equivocadas" ${ }^{\text {. }}$. Nos

\footnotetext{
${ }^{56}$ UOL Entretenimento: "É só sertanejo e pagode. O Brasil emburreceu devido à monocultura", diz Guilherme Arantes, 23/04/2013.

${ }^{57}$ UOL Entretenimento: “As letras do sertanejo são muito pouco desenvolvidas”, diz Nando Reis, 01/12/2015.

${ }^{58}$ Jornal do Brasil: "Sertanejo universitário é uma demência", diz Lobão, 01/04/2011.

${ }^{59}$ Jovem Pan: Renato Teixeira crítica o sertanejo universitário: espetáculo vale mais que conteúdo, 20/09/2013.

${ }^{60}$ Jovem Pan: Renato Teixeira crítica o sertanejo universitário: espetáculo vale mais que conteúdo, 20/09/2013.

${ }^{61}$ Universo Sertanejo: "Nosso meio é podre e eu tenho nojo", diz Jorge sobre o mercado da música sertaneja, 04/07/2012.
} 
últimos dez anos, Jorge e Mateus são os principais músicos sertanejos dessa nova geração, seja por repertório autoral, faturamento anual ou pelo público: "Há uma briga de bastidores hoje entre os escritórios que só atrapalha. Hoje, existem grupos isolados, escritórios que criam rixas com os outros, e isso não leva ninguém a nada. Eu estou com nojo disso, nojo"62.

Nos veículos de comunicação, o consenso entre jornalistas culturais e críticos musicais não é unânime. De acordo com o jornalista André Cáceras da Rádio UOL, musicalmente, o novo gênero consiste basicamente em uma simplificação e eletrificação do sertanejo da década de 1990 que, por sua vez, adveio do tal sertanejo de "raiz". Foram adicionados elementos do pop, rock, forró, arrocha e até mesmo do funk carioca, em uma linguagem mais moderna e urbana se comparada à música regional: "Essa mistura de influências foi fundamental para que o sertanejo alcançasse um público mais jovem nas capitais do país. E a internet também ajudou"63. Para Tiago Dias, o sertanejo abandonou o personagem sofredor para conquistar o público jovem: "Faz tempo que o personagem principal de uma canção sertaneja não sofre de amor. Depois do surgimento do sertanejo universitário, o personagem de hoje procura um novo amor ou busca na balada curar o coração partido. Os hits, com ritmo mais acelerado e com refrão repetido de onomatopeias, falam do flerte com o copo de bebida na mão e a confiança nas alturas ${ }^{\text {64 }}$. O cineasta e jornalista Arnaldo Jabor condenou a ascensão do "mau gosto" da música sertaneja: "Existem esses sertanejos porcarias, e um comentário de que tudo que critica é elitista. É uma ascensão do mau gosto. Tudo se massificou. O show de qualquer babaca enche" ${ }^{\text {"65 }}$. Luís Antônio Giron não é apocalíptico, embora saudosista: "A trilha sonora do Brasil se alterou profundamente nos últimos dez anos. A classe $\mathrm{B}$, que antes definia o gosto, cedeu primazia às classes $\mathrm{C}$ e $\mathrm{D}$. A mudança rebaixou a qualidade dos produtos musicais. Samba e MPB exibem um material artístico mais refinado que os pancadões e arrochos sertanejos. Esse universo de gosto se tornou relevante e essencial nas tendências de consumo. Porém, há ainda esperança, pois amanhã será outro dia" ${ }^{66}$. No portal Universo Sertanejo, André Piunti discute o novo cenário da música sertaneja, usando os compositores Sorocaba e Victor Chaves como alegorias referenciais:

\footnotetext{
${ }^{62}$ Universo Sertanejo: "Nosso meio é podre e eu tenho nojo", diz Jorge sobre o mercado da música sertaneja, 04/07/2012.

${ }^{63}$ Rádio UOL: Após anos dominando as paradas, até onde vai o sertanejo universitário? 02/03/2015.

${ }^{64}$ UOL Música: Com público mais jovem, sertanejo abandona personagem sofredor nas canções, 20/10/2014.

${ }^{65}$ Jornal Opção: Arnaldo Jabor critica música sertaneja e afirma que existe uma ascensão do mau gosto, 15/08/2015.

${ }^{66}$ Revista Época/Globo: O Brasil é sertanejo, 01/11/2013.
} 
Quem melhor entendeu o público dessa nova geração foi Sorocaba. Ele é criticado por suas músicas de estrutura e letras muito simples. Meteoro tem a mesma estrutura de Paga Pau, mas como discutir se as duas músicas conseguiram fazer muito sucesso? O último hit de Victor e Leo foi Borboletas, uma metáfora. Usar metáforas não tem sido um bom negócio, as letras de Victor são exceções. Mesmo assim, ele parece não se conformar em ver que muita gente não entendeu, até hoje, que 'sapo caiu na lagoa' também é uma metáfora. Assim como vai olhar decepcionado ao ver que muitos não entenderam como se bebe água de oceano. $\mathrm{O}$ público atual é tão infiel e volúvel, que troca facilmente um show sertanejo por um do Exaltasamba. Para quem só está a fim de festa, é basicamente a mesma coisa ${ }^{67}$.

A música sertaneja é até os nossos dias um dos maiores fenômenos de venda comercial brasileira. A institucionalização "universitária” à música sertaneja é recente. No entanto, a trajetória social do gênero é marcada por uma série de conflitos históricos entre grupos artísticos, intelectuais e institucionais, tanto dos setores rurais quanto urbanos, que datam há quase um século. Uma luta por afirmações e, sem sombra de dúvidas, daquilo que também é negado. Essa discussão sobre uma suposta autenticidade da música caipira tradicional em oposição ao comercialismo da música sertaneja está presente na pequena bibliografia especializada da música rural dos anos $1970^{68}, 1980^{69}, 1990^{70}$ e $2000^{71}$. Embora

\footnotetext{
${ }^{67}$ Universo Sertanejo: O novo sertanejo e o complicado público-preguiça, 25/04/2011.

${ }^{68}$ CALDAS, Waldenyr. Acorde na Aurora: Música Sertaneja e Indústria Cultural. Cia Ed. Nacional: São Paulo. 1977.
}

CANDIDO, Antonio. Os Parceiros do Rio Bonito: Estudo Sobre o Caipira Paulista e a Transformação dos Seus Meios de Vida (publicado originalmente em 1964) Livraria Duas Cidades Ltda.(4ed): São Paulo Edição, 1977.

MARTINS, José de Souza. Música Sertaneja: A Dissimulação na Linguagem dos Humilhados. In: Capitalismo e Tradicionalismo. Pioneira: São Paulo, 1975.

TINHORÃO, José Ramos. Pequena História da Música Popular: Da Modinha à Canção de Protesto. Editora: Vozes: Rio de Janeiro, 1974.

${ }^{69}$ BONADIO, Geraldo; SAVIOLI, Ivone. Música Sertaneja e Classes Subalternas. In: MELO José Marques de (org.) Comunicação e Classes Subalternas. São Paulo: Cortez, 1980.

FERRETE, J. L. Capitão Furtado: Viola Caipira ou Sertaneja? Instituto Nacional de Música, Divisão de Música Popular. Rio de Janeiro: Funarte, 1985.

KRAUSCHE, Valter. Música Popular Brasileira: Da Cultura de Roda à Música de Massa. São Paulo: Brasiliense. 1983.

${ }^{70}$ NEPOMUCENO, Rosa. Música Caipira: da Roça ao Rodeio. Editora 34: São Paulo. 1999.

PIMENTEL, Sidney Valadares. O Chão é o Limite: A Festa de Peão de Boiadeiro e a Domesticação do Sertão. Goiás: Editora UFMG, 1997.

ULHÔA, Martha Tupinambá de. Música Sertaneja e Globalização. In: TORRES, Rodrigo (org.). Actas Del II Congresso Latino-americano IASPM. São Paulo: Fondart, 1999. 
na literatura, essa controvérsia seja iniciada ainda nas décadas de 1910 e $1920^{72}$ por Monteiro Lobato e Cornélio Pires. Contudo, novos autores veem reexaminando essa indisposição no debate acadêmico ${ }^{73}$. Na atualidade, as trajetórias artísticas de Victor e Leo e Fernando e Sorocaba ilustram o conflito de identidades musicais ainda existentes nesse gênero. Portanto, o intuito fundamental aqui é investigar as novas configurações desse debate histórico dentro da música sertaneja, para assim, adensar e atualizar as análises desse fenômeno cultural.

Ressalta-se que a teoria de campo a ser trabalhada está baseada na fundamentação teórico-metodológica do sociólogo francês Pierre Bourdieu. Consequentemente, a música sertaneja refere-se ao campo da música popular brasileira, e dessa forma, não devemos remetê-la a um conceito stricto sensu e nem tomá-la como átomo isolado no espaço social. Dito isso, temos o reconhecimento de um jogo incessante de disputas comerciais e simbólicas entre os artistas sertanejos pela legitimidade de suas produções e posições no interior desse microcosmo social. O historiador Gustavo Alonso ${ }^{74}$ e o antropólogo Allan de Paula Oliveira ${ }^{75}$

ZAN, José Roberto. Música Caipira: Da Roça a Nashville. Revista do Núcleo de Desenvolvimento da Criatividade da Unicamp. Campinas: NUDECRI, 1994.

${ }^{71}$ FAUSTINO, Jean Carlo. A Moda de Viola na Era da Sua Reprodutibilidade Técnica. Trabalho apresentado na ANPOCS, 2009.

MUGNAINI JR, Ayrton. Enciclopédia das Músicas Sertanejas. Rio de Janeiro: Letras \& Letras. 2001.

RIBEIRO, José Hamilton. Música caipira: As 270 Maiores Modas de Todos os Tempos. São Paulo: Globo. 2006.

SANT’ANNA, Romildo. A Moda é Viola: Ensaio do Cantar Caipira. São Paulo: Arte \& Ciência; Marília, SP: Ed. UNIMAR. 2000.

SOUZA, Walter de. Moda Inviolada: Uma História da Música Caipira. Quíron Livros. São Paulo. 2005.

${ }^{72}$ LOBATO, Monteiro. Urupês. In: Lobato, M. Obras Completas. São Paulo: Brasiliense, 1918.

PIRES, Cornélio. Conversas ao Pé do Fogo. São Paulo: Tipografia Piratininga. 1921.

${ }^{73}$ ALONSO, Gustavo. Cowboys do Asfalto: Música Sertaneja e Modernização Brasileira. Tese de Doutorado apresentada à Universidade Federal Fluminense: Rio de Janeiro, 2011.

OLIVEIRA, Allan de Paula. Miguilim Foi pra Cidade Ser Cantor: Uma Antropologia da Música Sertaneja. Tese de Doutorado em Antropologia Social apresentada à Universidade Federal de Santa Catarina, 2009.

VILELA, Ivan. Cantando a Própria História: Música Caipira e Enraizamento. São Paulo: EDUSP, 2014.

74 "Demarca-se aqui que esse pensamento forjado nos anos 70 foi essencial para a construção, delimitação e distinção de campos culturais diferenciados na música rural. Pensando através das categorias de Bourdieu, a música caipira foi sendo ao mesmo tempo 'inventada' enquanto projeto estético e campo cultural ao mesmo tempo em que criava e delimitava sua oposição, os sertanejos. Em diálogo dinâmico de autonomia relativa, foram sendo gestados campos gradualmente opostos", (Ibidem, 2011, p. 176). 
concluíram que esses conflitos institucionais e artísticos existentes na música caipira/sertaneja forjaram dois campos autônomos na música rural brasileira. Nesse ponto, penso que os dois autores cometeram um erro analítico ao adotar o conceito bourdieusiano de campo nesse sentido tão restrito. De fato, houve tensões em diferenciá-las (música caipira versus música sertaneja) - sobretudo, pelos artistas que se consideravam porta-vozes da "verdadeira" música rural caipira (Inezita Barroso, Rolando Boldrin e Renato Teixeira). Os intelectuais e artistas das esquerdas nacionais-populares engajados nas canções de protesto também se predispuseram contra a música sertaneja. Mas, em um campo musical autônomo, a luta por diferenciações de gêneros e subgêneros "legítimos" ou "ilegítimos" é a força motriz que sustenta a dinâmica do jogo. Pensando por meio do conceito de campo de Pierre Bourdieu, tanto a música caipira quanto a música sertaneja - seja ela de raiz, moderna, romântica ou universitária - está inserida nessa mesma trama de tensões, conflitos e disputas do microcosmo $^{76}$ da música popular brasileira.

\section{IV - Estudo de caso e os procedimentos de análise}

A reconstrução da história social ${ }^{77}$ das duas duplas sertanejas foi a matéria-prima deste trabalho. Foi por meio da investigação da trajetória social dos quatros músicos que pude ter acesso às particularidades do desempenho cênico-artístico durante a pesquisa de campo. $\mathrm{O}$ estudo de caso foi composto pelos irmãos Victor e Leonardo Chaves e por Fernando Zorzanello e Fernando Fakri de Assis "Sorocaba". Desde 2007, eles têm disputado a liderança

\footnotetext{
75 “Este processo, na música popular, começou a ganhar relevo a partir do final dos anos 20, sendo que a música sertaneja da região do Centro-Sul (a região caipira) é um dos veículos deste processo - o que significa uma dupla perspectiva: ela é, ao mesmo tempo, produto e produtora deste processo. Foi, portanto, a partir deste momento que o campo da música sertaneja começou a se cristalizar, ou nos termos de Bourdieu, a adquirir sua autonomia relativa [...] Tal processo de cristalização preencheu aproximadamente vinte e cinco anos, ocorrendo até a segunda metade dos anos 50, quando a música sertaneja apareceu completamente constituída enquanto campo musical, com autonomia em termos de discurso estético, de formas musicais, de relações de produção e de meios de veiculação", (Ibidem, 2009, p.234).

76 "A teoria geral da economia dos campos permite descrever e definir a forma específica de que se revestem, em cada campo, os mecanismos e os conceitos mais gerais (capital, investimento, ganho), evitando assim todas as espécies de reducionismo, a começar pelo economicismo, que nada mais conhece além do interesse material e a busca da maximização do lucro monetário. Compreender a gênese social do campo, e apreender aquilo que faz necessidade específica de crença que os sustenta, do jogo de linguagem que nele se joga, das coisas materiais e simbólicas em jogo que nele se gerem, é explicar, tornar necessário, subtrair ao absurdo do arbitrário e do não motivado os atos dos produtores e as obras por eles produzidas, e não, como geralmente se julgam reduzir ou destruir" (BOURDIEU, Pierre. A Distinção: Crítica Social do Julgamento, 2007, p.69).

${ }^{77}$ Cf. MICELI, Sergio. Imagens Negociadas: Retratos da Elite Brasileira (1920-40). São Paulo: Companhia das Letras, 1996 e Nacional Estrangeiro: História Social e Cultural do Modernismo Artístico em São Paulo. São Paulo: Companhia das Letras, 2003. O autor é uma importante referência no universo da sociologia da cultura, sobretudo, pelo método analítico de história social dos intelectuais e artistas brasileiros.
} 
do mercado da música sertaneja. No entanto, notei que seria ingenuidade analisá-los apenas através de uma competição meramente econômica. Os duetos sinalizavam identidades musicais muito distintas entre si. Claro, publicamente, nunca chegaram a pleitear a legitimidade de uma à custa de outra. Eles procurariam outras vias: no discurso com os espectadores dos shows, nas entrevistas para os veículos de comunicação, na sonoridade instrumental, nas letras das canções, na roupagem ou no desempenho cênico - dentro e fora dos palcos.

É oportuno ilustrar um embate recente entre eles. Para tanto, descrevo um episódio do quadro Bem Sertanejo do programa Fantástico, apresentado pelo músico sertanejo Michel Teló e exibido pela Rede Globo ${ }^{78}$. Os convidados: Victor e Leo e Fernando e Sorocaba. Apesar da ambientação amistosa, é possível notar certo mal-estar entre as duplas. Em uma passagem, Victor enaltece a influência do universo rural mineiro em sua composição artística: “A música que levou o grande público a conhecer a gente foi Vida Boa. Falei: 'cara vou fazer uma música de um sapo'. Fiquei lembrando a avó contando história da carochinha, história de um sapo que caiu na lagoa e é recebido com uma festa no céu”. Logo, é Sorocaba quem responde: “Apesar do apelido de Sorocaba, eu nasci na capital de São Paulo. Mas eu convivi bastante no interior. No começo, eu fazia as composições para aquele ambiente, era coisa bem restrita, só quem mexia com cavalo entendia [seu avô era dono de um haras no interior paulista]". Michel Teló fica intrigado e prossegue: "Mas você não compõe em um ritmo mais pop?”. Sorocaba replica: “Eu sempre gostei muito de ouvir música country americana e o pop também”. Após alguns segundos de embaraço, Sorocaba retoma a resposta em um tom mais enfático e irônico: “Olha, se você compor [sic] algo muito rebuscado, que só você entende, não dá certo. Se você compor [sic] algo muito popular, você é muito bobinho. Tem que ir afinando".

Inicialmente, a escolha por duas duplas me pareceu arbitrária, embora justificável. As fontes bibliográficas sobre a música sertaneja são relativamente escassas - fosse ela caipira, de raiz, moderna, romântica ou universitária. Quando existente, os relatos eram frágeis e os depoimentos acusatórios. Essa indisposição, na maior parte das vezes, objetivava um problema em comum: música caipira não era sinônima de música sertaneja - ainda que parcela da intelectualidade acadêmica e artística aceitasse a primeira como sendo "legítima" e

\footnotetext{
${ }^{78}$ Fonte: Bem Sertanejo, quadro do programa Fantástico (Rede Globo): Michel Teló mostra negócio milionário que a música sertaneja movimenta, exibido em 19/10/2014.
} 
a segunda como mera reprodução "comercial" da indústria cultural. A pesquisa empírica foi o lastro crucial para reconstituição dos conflitos que acompanham a nova geração da música sertaneja. Afinal, Victor e Leo e Fernando e Sorocaba são artistas frutos desse processo histórico de diferenciação e, ao mesmo tempo, são também os próprios coautores dessa trama diferenciadora. O estudo de caso desses músicos sertanejos consagrados foi decisivo para construção de um retrato descritivo, analítico e comparativo das atuais dinâmicas culturais da música sertaneja.

De acordo com o Escritório Central de Arrecadação e Distribuição (ECAD), órgão responsável pelos direitos autorais musicais, Victor Chaves foi o autor que mais arrecadou direitos autorais entre 2008, 2009 e 2010, enquanto Sorocaba ocupou a segunda colocação em 2010. Em 2011 e 2012, as posições se inverteram: Sorocaba passou a ocupar a liderança à frente de Victor Chaves. Hoje, são os artistas mais expressivos, não apenas no gênero sertanejo, mas em todo o cenário musical brasileiro. No total, acompanhei seis espetáculos realizados pelos músicos na cidade de São Paulo. Estive em quatro shows de Victor e Leo: Terra Country Interlagos, Espaços das Américas, Citibank Hall e na gravação do DVD Ao Vivo Irmãos, e mais duas apresentações de Fernando e Sorocaba: Terra Country Interlagos e Citibank Hall.

Tal análise comparativa versou compreendê-los em três esferas:

(A-) Uma avaliação discursiva e estrutural das letras das canções. Selecionei períodos diferentes da produção artística de Victor e Leo e Fernando e Sorocaba, indicando possíveis modificações contextuais em suas músicas ao longo do tempo. Além de uma exposição do universo temático apropriado pela nova geração do gênero.

(B-) O exame das sonoridades instrumentais elaboradas no trabalho musical dos duetos, descritos aqui pelo violista e professor da Universidade de São Paulo Ivan Vilela ${ }^{79}$. Nesse quesito, abro algumas ressalvas. Embora tenha feito um registro mínimo dos instrumentos apresentados nos shows, interessava-me apontar algo mais técnico. Reconheço que suas interpretações carreguem, às vezes, certo teor ideológico e estético. Sendo esta uma

\footnotetext{
${ }^{79}$ Embora esteja no polo erudito da música caipira/sertaneja, o violista Ivan Vilela faz parte dessa disputa e, portanto, sua interpretação é subjetiva e seus conceitos não podem ser lidos aqui como construções objetivas de análise sociológica.
} 
pesquisa sociológica e não musical, integro seus comentários somente como explicações sobre as técnicas de canto e dos artefatos instrumentais usados pelas duas duplas sertanejas, não tomando as descrições como categorias de análise social.

(C-) O desempenho performático e cênico ${ }^{80}$ dos artistas registrados nos shows e espetáculos em São Paulo. Examinando a héxis ${ }^{81}$ e o apelo corporal mobilizado no palco, as indumentárias, as teatralizações encenadas pelas duplas e a base pactual de interação com o público, além da ambientação espacial dos cenários ilustrados por meio das fotografias coletadas nos espetáculos.

Nos dois primeiros capítulos, trago a história social de Victor e Leo e de Fernando e Sorocaba. Em ambos, discuto as redes de sociabilidade, as origens sociais e as trajetórias sociais dos quatro músicos sertanejos. Tanto em um quanto em outro, discuto as novas configurações da indústria fonográfica brasileira e, sobretudo, quais foram as condições históricas, econômicas e socioculturais que possibilitaram o sucesso mercadológico da nova música sertaneja. Nesse percurso, aponto também a competição artística e institucional existente entre os dois duetos pela legitimidade comercial e simbólica de suas produções musicais.

No capítulo 1, esboço a relação de parceria afetiva-profissional estabelecida entre os irmãos mineiros Victor e Leonardo Chaves, e também, os conflitos artísticos e familiares existentes ali. No primeiro item, descrevo o projeto de revalorização da música sertaneja

\footnotetext{
${ }^{80}$ A abordagem teórico-metodológica do sociólogo norte-americano Erving Goffman foi o roteiro para construção da análise do desempenho cênico dos músicos: "A perspectiva empregada [...] é a da representação teatral e os princípios [...] são de caráter dramatúrgico. Considerarei a maneira pela qual o indivíduo apresenta, às outras pessoas [...] enquanto realiza seu desempenho diante delas [...] $\mathrm{O}$ palco apresenta coisas que são simulações. Presume-me que a vida apresenta coisas reais e às vezes bem ensaiadas. Mais importante, talvez, é o fato de que no palco um ator se apresenta sob a máscara de um personagem para personagens projetados por outros atores. A plateia constitui um terceiro elemento da correlação, elemento que é essencial, e que, entretanto, se a representação fosse real, não estaria lá. Na vida real, os três elementos ficam reduzidos a dois: o papel que um indivíduo desempenha é talhado de acordo com os papeis desempenhados pelos outros presentes, e ainda, esse outros também constituem a plateia" (GOFFMAN, Erving. A Representação do Eu na Vida Cotidiana, 1983, p.9).

81 "A héxis corporal fala imediatamente à motricidade, enquanto esquema postural que é ao mesmo tempo singular e sistemático, pois é solidário de todo um sistema de técnicas do corpo e de instrumentos, e carregado de uma miríade de significações e de valores sociais: as crianças são particularmente atentas, em todas as sociedades, a esses gestos ou essas posturas onde se exprime a seus olhos, tudo aquilo que caracteriza um adulto, um caminhar, uma postura de cabeça, caretas, maneiras de sentar-se, de manejar instrumentos, cada vez associados a um tom de voz, a uma forma de falar e - como poderia ser de outra forma? - a todo um conteúdo de consciência" (BOURDIEU, Pierre. Esboço de uma Teoria da Prática, 1983, p. 185).
} 
encabeçado pelo compositor Victor Chaves e a radicalização de sua crítica ao novo cenário cultural da música sertaneja. Em um segundo momento, mostro as transformações mercadológicas na carreira de Leonardo Chaves, orientadas pelo escritório Som Livre (Organizações Globo) desde 2013. Investigo nesse trecho, o desempenho empresarial do cantor fora dos palcos.

No capítulo 2, avalio a atuação artística e empreendedora de Fernando Fakri de Assis "Sorocaba" na indústria fonográfica brasileira. Nesse ponto, vasculho as estratégias tecnológicas adotadas por ele para diferenciação e liderança artística no mercado do show business da música sertaneja. Para tanto, examino sua iniciativa empresarial de estabelecer um novo formato comercial ao gênero - o cine-show (longa-metragem e DVD musical em um único produto audiovisual) e a tarefa de agenciamento de novos artistas para o elenco do seu escritório particular. Será abordada também a relação estritamente profissional entre Sorocaba e o companheiro de dupla, o músico Fernando Zorzanello.

No capítulo 3, encaminho a discussão para uma interpretação comparativa do arcabouço cancioneiro dos dois duetos (itens A e B), indicando os novos componentes temáticos do gênero sertanejo e, ao mesmo tempo, contextualizando o conflito de identidades musicais que está objetivado nas composições de Victor Chaves e Fernando Fakri de Assis "Sorocaba" " 82 .

Nos capítulos 4 e 5, analiso individualmente os espetáculos de Victor e Leo e de Fernando e Sorocaba (item C), registrados na cidade de São Paulo. O intuito fundamental dos dois capítulos é descrever a interação entre palco-plateia, palco-bastidor e os jogos teatrais confeccionados nos shows pelos artistas sertanejos. Em ambos os capítulos, traço o perfil do público-consumidor e a recepção fonográfica paulistana das duplas. Por fim, a partir das fotografias, analiso a apropriação corporal, indumentária e coreográfica dos músicos nos palcos e também os artefatos cênicos que compõem o cenário e o imaginário afetivoemocional do público institucionalizado no carisma do artista.

\footnotetext{
${ }^{82}$ No terceiro capítulo, abro mão de qualquer dicotomia existente na sociologia entre leitura externa (contextual) versus leitura interna (textual) das obras musicais $\mathrm{O}$ paradigma bourdieusiano permite a conciliação e a mediação entre esses dois entes que são analiticamente interdependentes.
} 


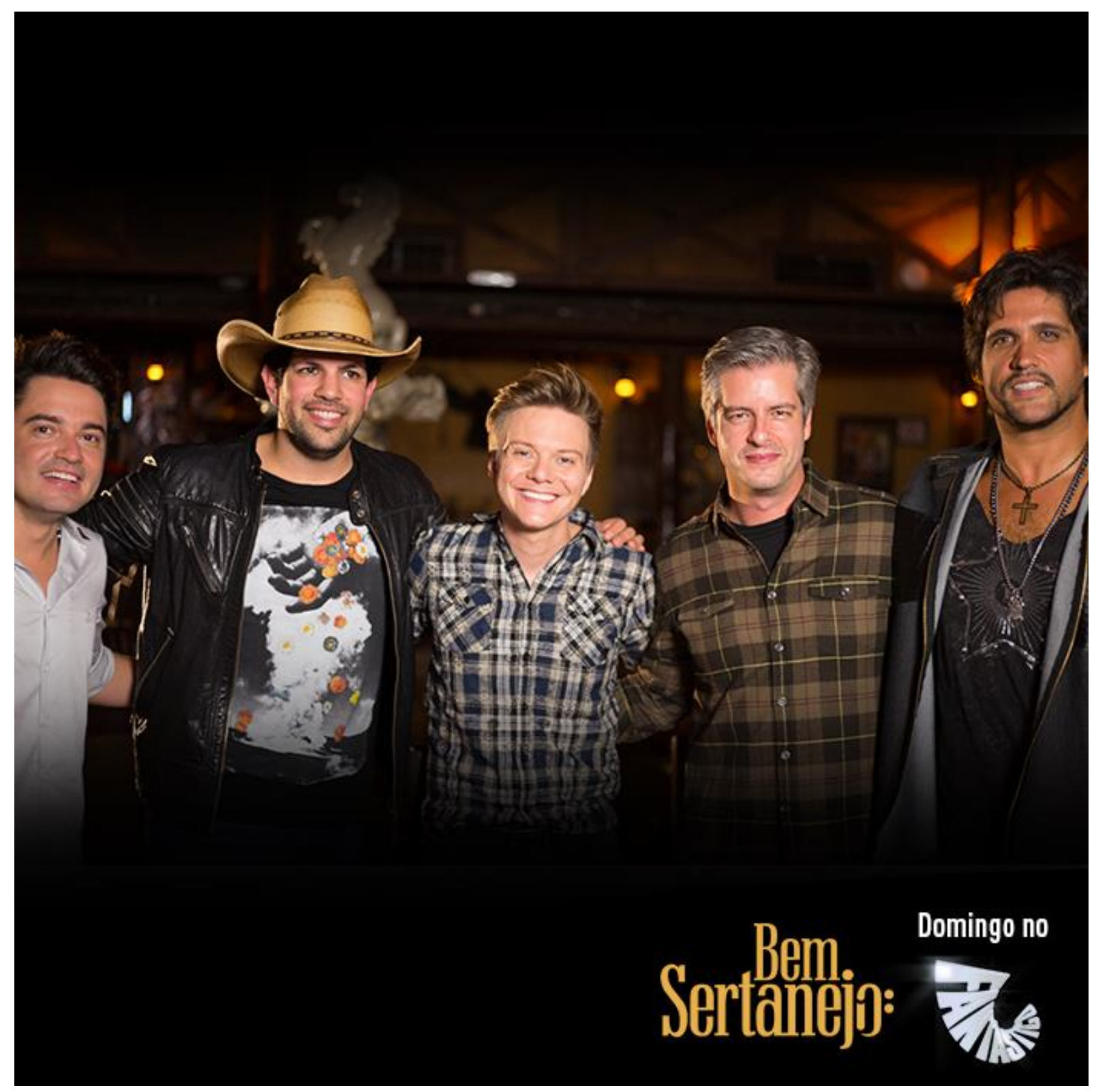

Índice ilustrativo dos quatro artistas sertanejos.

No dia 19 de outubro de 2014, Victor \& Leo e Fernando \& Sorocaba foram os convidados do quadro Bem Sertanejo do programa Fantástico, exibido na Rede Globo ${ }^{83}$. O músico Michel Teló (ao centro) foi o mediador do encontro entre Fernando Zorzanello (à esquerda) \& Fernando Fakri de Assis "Sorocaba" (à esquerda, de chapéu) e Victor Chaves (à direita, de camisa xadrez) \& Leo Chaves (à direita).

${ }^{83}$ Fonte: Bem Sertanejo, programa Fantástico (Rede Globo): Michel Teló mostra negócio milionário que a música sertaneja movimenta, exibido em 19/10/2014. Foto: Divulgação/Rede Globo. 


\section{Os irmãos caipiras: a trajetória dos músicos mineiros Victor e Leo}

Fomos criados em meio à simplicidade interiorana. Particularmente, tenho um sertão próprio e místico dentro de mim. Minhas canções bucólicas representam tentativas de descrevê-lo.

O significado de uma canção está no sentimento de quem ouve. O que faço é o que sinto. O que sinto não saberia explicar. Para mim, compor é uma necessidade nada pretenciosa e completamente inexplicável. O que imprimo em minha arte é o fator emoção.

Mantenho minha intuição artística sempre limpa para que flua. Fico longe da informação inútil e exagerada. Não ouço nem rádio e nem assisto TV. Gosto do silêncio, do contato com a natureza. Assim, consigo ouvir melhor minhas vozes interiores. São elas que ditam para mim o que escrevo e o que toco a partir de meus sentimentos ${ }^{84}$.

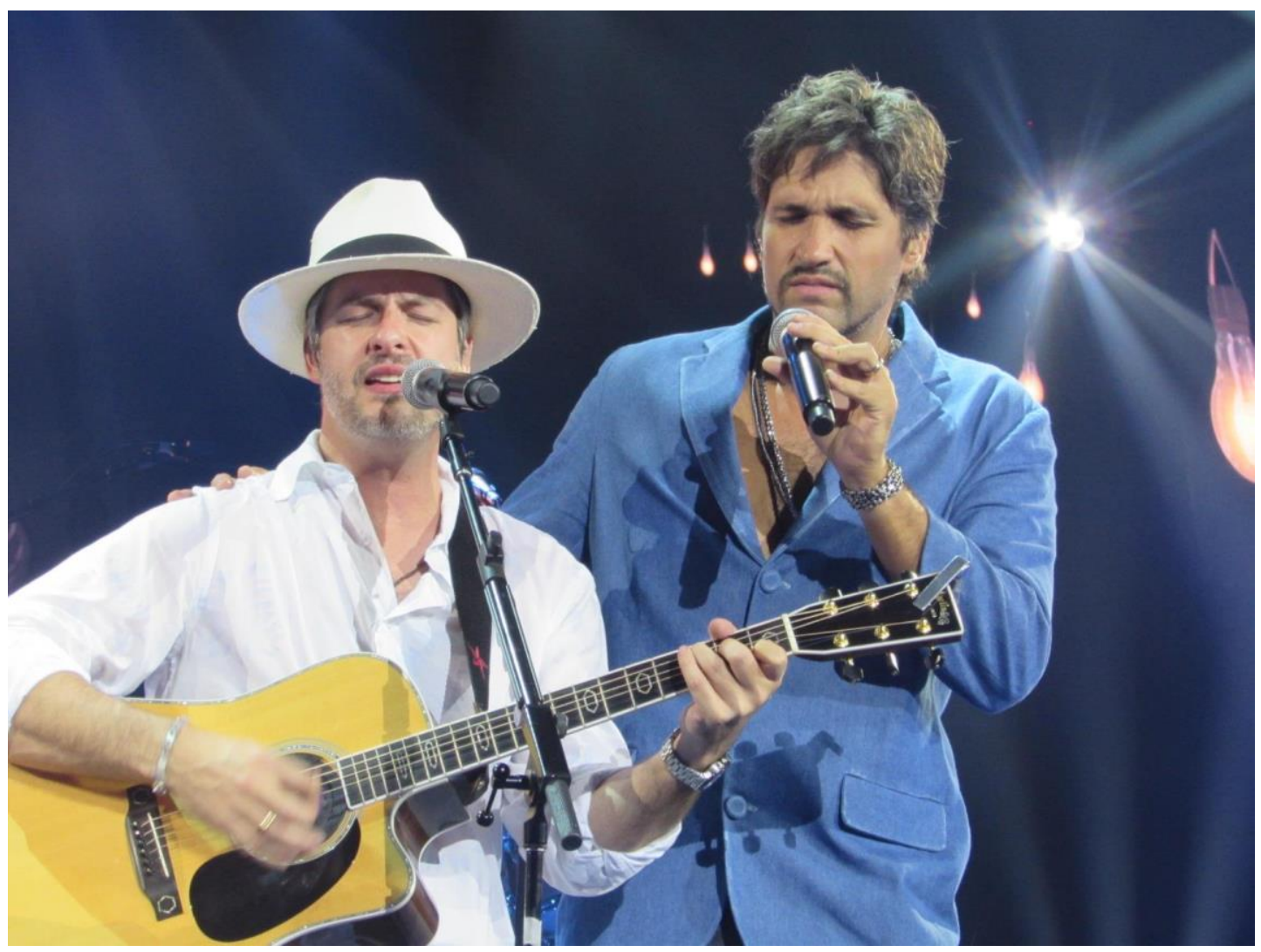

Gravação do DVD Ao Vivo Irmãos realizada no dia 28 de janeiro de 2015, no Estúdio Quanta, Vila Leopoldina, zona oeste de São Paulo. Victor à esquerda no violão e Leonardo à direita nos vocais. Foto: Edy Betty.

\footnotetext{
${ }^{84}$ Victor Chaves. Fonte: do autor (2015).
} 
Victor Chaves é popularmente conhecido como "poeta". Em hipótese, atribuo esse codinome devido ao estilo romântico próximo ao lírico de suas composições, e também, por sua habilidade no uso do violão, dedilhado frequentemente com os olhos fechados. No repertório musical do compositor, há sempre uma mensagem de valorização da simplicidade sertanista/interiorana e de exaltação da espiritualidade da vida, baseada em Deus, no amor e na felicidade - componentes que fazem parte da sua própria experiência social. $\mathrm{O}$ "sertão místico" (o primado da forma em face ao conteúdo), "a emoção e o sentido da arte musical" (a arte pela arte), "as vozes interiores que ditam a composição" (autonomia artística), "o ensejo inexplicável do artista solitário" (estética pura), “a intuição artística limpa” (olhar puro) e todos os elementos do seu discurso, vistos na epígrafe, estão longe de ser um "dom natural" da "arte pura" - foram construídos socialmente ao longo de quinze anos de estrada profissional ao lado do irmão, nos bares e casas noturnas de Belo Horizonte (MG), Uberlândia (MG) e da grande São Paulo, e ainda, na socialização prematura com a música investida por sua família. Antes de se tornar poeta e de naturalizar as categorias artísticas, Victor teve que conhecer as agruras daqueles que dependem economicamente da música, de uma arte que também imita as condições objetivas de existência social do artista.

No documentário Nada És Normal (2008), observamos cenas de Victor, ainda na primeira infância, apoiado sob o violão. Esse desenvolvimento musical precoce foi fortemente estimulado por sua família: "Houve muito incentivo. Sempre tinha uma roda familiar requisitando que eu tocasse" ${ }^{, 55}$. A primeira apresentação ao lado de Leonardo aconteceu, em 1992, na cidade de Abre Campo (Zona da Mata mineira) em um bar local simples, apenas em voz e violão. O contato profissional com a música ocorreu em 1994, quando se mudaram para Belo Horizonte (MG). Ficaram por sete anos cantando e tocando nos bares noturnos da capital mineira, enquanto estudavam canto: "Meu aprimoramento foi autodidata. Criei minha própria maneira de tocar. Minha primeira composição a chamei de 'invenção', pois não conhecia o verbo compor, muito menos um compositor" ${ }^{\prime 86}$. Essa invenção de uma estética pura e a reprodução de uma ideologia romântica do artista como "criador incriado" é muito comum na fala do compositor. Está presente, do mesmo modo, em sua postura corporal e na naturalidade cênica desempenhada ao lado do irmão. Então, examinemos a origem e a trajetória social de Victor e de seu parceiro Leo Chaves.

\footnotetext{
${ }^{85}$ Entrevista de Victor Chaves ao autor, 09 de julho de 2015.

${ }^{86}$ Victor Chaves. Fonte: do autor (2005).
} 
Victor (nome artístico de Vitor Chaves Zapalá Pimentel - 15 de abril de 1975) e Leo (nome artístico de Leonardo Chaves Zapalá Pimentel - 04 de outubro de 1976) nasceram em Ponte Nova (MG), mas foram criados na cidade Abre Campo (região da Zona da Mata mineira), na fazenda dos bisavôs paternos Juca e Carolina Zapalá, emigrantes da Dinamarca e Itália. São filhos únicos de Ronald Zapalá (bancário aposentado do Banco do Brasil) e Marisa Chaves (dona de casa e recentemente graduada no curso de psicologia). Provenientes do interior mineiro, de uma família de classe-média, avós imigrantes, os irmãos não possuem nenhum título universitário, apenas completaram o ensino médio. O desenvolvimento instrumental de Victor Chaves foi praticamente autodidata e fortemente influenciado pela família. Há vídeos pessoais da dupla apontando o uso do instrumento ainda na primeira infância. Ambos tiveram uma importante influência cultural dos avôs: "Nossa avó paterna, Beatriz, é poetiza, declamadora de versos, uma cantora maravilhosa, pintora e escritora. Não há dúvidas de que sua presença nos despertou para o dom que tínhamos" ${ }^{\text {" }}$. O avô materno, Tonico Chaves, foi outra figura familiar importante: "Ouvia canções do regional sertanejo na radiola do meu avô, tendo sido meu primeiro contato com a música, principalmente nas vozes de Sérgio Reis, Renato Teixeira e Almir Sater" ${ }^{\text {}} 88$. O valor do avô é significativo também a Leonardo: “Ouvíamos Sérgio Reis dormindo no colo do nosso avô. Pequenininhos, tanto eu quanto o Victor, com cinco ou seis anos de idade" ${ }^{\text {. }}$.

$\mathrm{Na}$ adolescência, tiveram contato com outros gêneros, como o country norteamericano (James Taylor e Dire Straits), o rock (Eric Clapton) e o regionalismo brasileiro (Alceu Valença e Zé Ramalho) $^{90}$. As novas sonoridades vieram através das trocas culturais entre os amigos da cidade, pela TV e principalmente pelo rádio. Leonardo já acompanhava o irmão desde a infância. Cantavam sem pretensões: apenas faziam músicas para os amigos e para família. A intenção profissional ainda era pouco clara para eles. Aos 11 anos, Victor teve algumas aulas de música com um professor em Abre Campo: "Mas logo parei e segui do meu jeito, sem muito empenho até os 17 anos, quando comecei a cantar com Leo. Em 1993, aos 18

\footnotetext{
${ }^{87}$ Idem, 09 de julho de 2015.

${ }^{88}$ Victor Chaves. Fonte: site oficial da dupla.

${ }^{89}$ Entrevista de Leonardo Chaves ao programa Fantástico (Rede Globo), exibida em 19/10/2014.

90 “Não há como citar tudo. Mas em peso igual e momentos diferentes, entre outros há: Sérgio Reis, Milionário e José Rico, Renato Teixeira, Almir Sater, Alceu Valença, Zé Ramalho, Pepeu Gomes, RPM, Roupa Nova, Chitãozinho e Xororó, Zezé Di Camargo e Luciano, Leandro e Leonardo, Chrystian e Ralf e Skank", depoimento de Victor Chaves ao autor, 09 de julho de 2015.
} 
anos fiz minha primeira canção. Chama-se Flor do Campo, gravada no álbum Boa Sorte Pra Você, de 2010" 91 .

Victor e Leo iniciaram a carreira musical em 1992, ainda na cidade de Abre Campo (MG). Em 1994, mudaram-se para Belo Horizonte (MG). Lá, os irmãos se apresentaram durante sete anos nos bares da noite mineira. Durante cinco anos, estudaram canto com o cantor lírico e professor de música Amin Feres, da Universidade Federal de Minas Gerais. A partir de 2001, os irmãos buscariam novos rumos na carreira: o público paulistano. Passaram a se apresentar nos bares, botecos e casas noturnas da capital e em regiões mais periféricas da grande São Paulo, como Barueri e Osasco ${ }^{92}$. Permaneceram seis anos e meio em terras paulistas. O compositor lembra com carinho dessa época: "Sempre amei tocar em bares. O início foi trabalhoso, mas depois, com público crescente e cativo, vivíamos muito bem da música. Passaria a vida cantando assim. Eu amava esses lugares e não tinha nenhuma loucura em obter fama ou grandes patamares. O que podia fazer era melhorar a arte e foi isso que nos cresceu"93. Em 2007, eles decidiram morar definitivamente na cidade que foi o palco do primeiro DVD e da consagração nacional da dupla: Uberlândia (MG).

Foram quinze anos de estrada até o reconhecimento midiático e do grande público: “A coisa foi acontecendo enquanto estávamos nos bares. Acompanhei por nosso site, em 2006, a chegada de cada vez mais e-mails de partes diferentes do Brasil pedindo os CD's ao vivo originais, uma vez que os mesmos estavam sendo pirateados. Não sabíamos que o CD havia se espalhado dessa forma. Havia centenas de e-mails de rádios pedindo as canções por mp3, para serem executadas gratuitamente" 94 . Em junho de 2007, a gravadora Sony-BMG relançou o terceiro ${ }^{95}$ álbum dos músicos: Victor \& Leo Ao Vivo, modificando somente a capa. Em

\footnotetext{
${ }^{91}$ Entrevista de Victor Chaves ao autor, 09 de julho de 2015.

92 Após o reconhecimento nacional (2006-2008), novos espaços se abriram: Villa Country (Água Branca), Estância Alto da Serra (Ribeirão Pires), Espaço Daslu (Cerqueira César), HSBC Brasil (Chácara Santo Antonio), Espaço das Américas (Barra Funda), Terra Country (Interlagos) e Citibank Hall (antigo Credicard Hall, Santo Amaro) - neste último, os irmãos fazem shows durante o mês de dezembro desde 2008. Em restaurantes (na forma de show-jantar) como: São Judas Demarch (ABC paulista), Caipirão (Embu), Rancho do Sertão (São Bernardo do Campo), Hotel Jequitimar em São Vicente, Caraguatatuba e Ubatuba. Em locais abertos como Hopi Hari e Sambódromo do Anhembi.

${ }^{93}$ Idem, 09 de julho de 2015.

${ }^{94}$ Idem, 09 de julho de 2015.

95 O primeiro CD foi lançado em 2002 pela extinta gravadora Number One. Depois, produziram dois álbuns independentes: Vida Boa (2004) e Victor \& Leo Ao Vivo (2006) - este último relançado pela gravadora SonyBMG, em 2007.
} 
trinta dias, o trabalho rendeu um disco de ouro (cinquenta mil cópias), mesmo tendo sido pirateado em diversos estados e regiões brasileiras. No mesmo mês, o escritório da Sony promoveu a gravação do primeiro DVD e o quarto CD da dupla: Ao Vivo em Uberlândia. Quando os músicos fecharam contrato com a Sony, a gravação em Uberlândia estava definida. E, mesmo sem gravadora, o show teria que ocorrer, pois estava com data marcada e os ingressos já tinham sido vendidos. Entre outubro de 2006 e junho de 2007, os irmãos fizeram grandes e crescentes shows por diversos estados brasileiros, mas ainda não tinham gravado DVD ao vivo nem tampouco fizeram presença na TV: "Para mim, foi a melhor fase. Não ser conhecido fisicamente e ter grandes plateias cantando todo o nosso repertório. A música sertaneja estava em baixa e se dizia que nenhuma dupla despontaria novamente no cenário nacional. Creio que a originalidade do nosso som, como algo completamente novo, casou com esta maré baixa para música sertaneja. As rádios pediam que enviássemos as canções pelo site, dizendo que eram as mais pedidas, mesmo que nunca antes tocadas"

Algumas considerações feitas pelo músico merecem uma análise. O período de aclamação nacional de Victor e Leo ocorreu concomitantemente à promoção do movimento universitário na música sertaneja. Iniciado nos anos 2000, o auge da música universitária aconteceu entre os anos de 2005, 2006 e 2007 - mesma data de reconhecimento da dupla mineira. Ao afirmar que: “A música sertaneja estava em baixa”, Victor não se refere ao sucesso comercial do gênero que, aliás, passou a faturar cifras ainda maiores que o sertanejo romântico dos anos 1990. Ele atribui "essa maré baixa da música sertaneja" ao status cultural e não à situação morfológica do gênero. A “originalidade do nosso som” que Victor diz ter sido atribuída a eles naquele momento revela sua oposição ao movimento universitário, ainda que os mesmos, tenham se beneficiado do sucesso desse. Isso justificava a revalorização de uma suposta tradição caipira sobre a qual o artista costuma discursar frequentemente, assim como as parcerias musicais com Renato Teixeira e Almir Sater - ícones do gênero dito “tradicional”. Quem despontaria nessa conjuntura "de pouca originalidade” seria Sorocaba maior competidor de mercado fonográfico da dupla desde então:

Victor e Leo apareceram durante a ascensão do sertanejo universitário e carregaram esse termo durante muito tempo, e isso sempre os incomodou. A moda naquele momento era pegar músicas antigas, tocar de forma acelerada, mudar um pouquinho o gênero e requentar músicas dos anos 1990, e eles nunca fizeram isso. O sertanejo universitário vem com uma força tão grande que impulsionou o mercado de shows, tendo grande destaque nas emissoras

\footnotetext{
${ }^{96}$ Entrevista de Victor Chaves ao autor, 09 de julho de 2015.
} 
de rádio e TV. Muitos artistas se aproveitaram daquele momento, e eles também ${ }^{97}$.

No ano de 2009, produziram o segundo DVD acústico: Victor \& Leo Ao Vivo em São Paulo com a participação de Alcione e Renato Teixeira. O renomado produtor musical Guto Graça Mello (responsável pelas gravações de Roberto Carlos) coordenou o oitavo disco da carreira dos músicos: Boa Sorte Pra Você (2010). Em 2011, o nono álbum Amor de Alma teve mais de três milhões de cópias vendidas. O décimo CD: Ao Vivo em Floripa (2012) contou com a presença de artistas como Zezé Di Camargo e Luciano, Chitãozinho e Xororó e Paula Fernandes. Entre 2009 e 2012, pode-se dizer que a dupla ganhou maior reconhecimento, não somente do público, mas da crítica musical: "Temos plateias enormes em todas as regiões do país. Acho que sempre obtivemos respeito pela seriedade com que levamos nosso trabalho. Mas isso é uma coisa que se deve fazer sempre, para que o sucesso cresça e não apenas se mantenha" 98 .

A partir de 2013, a gravadora Som Livre passou a ser a responsável pelas produções da dupla ${ }^{99}$. Atualmente, a carreira é gerenciada pelo escritório Vida Boa Shows e Eventos sede em Uberlândia (MG). Victor Chaves é o autor das composições e arranjos, e aparece como segunda e primeira voz. Faz uso predominante do violão em cordas de aço ${ }^{100}$ (timbre mais "duro", semelhante ao violão folk norte-americano) e da guitarra elétrica ${ }^{101}$. Leonardo Chaves apresenta-se apenas como primeira voz e sem uso de qualquer instrumento - o cantor virtuose. Sobre a relação com o irmão caçula, Victor assume que há bastante discussão e conflito com o Leo, mas que ambos sabem que é por uma "boa causa": "No fim, o resultado compensa. Atualmente, visto minhas canções e ele veste as dele. Depois, nos encaixamos nos trabalhos um do outro. Ele tem o seu estilo ${ }^{102}$. Respeito isso sem avaliar. Ele é meu parceiro,

\footnotetext{
${ }^{97}$ Entrevista de André Piunti ao autor, 22 de novembro de 2014.

${ }^{98}$ Entrevista de Victor Chaves ao autor, 09 de julho de 2015.

99 Antes, eles eram da Sony BMG (2007-2013) e, nos Estados Unidos, a BNA Records/Colúmbia Records (2008).

${ }^{100}$ Baixo, contrabaixo, guitarra e bateria são orientados pelos integrantes da banda oficial.

101 “Cada canção pede um instrumento, uma roupa, uma ideia. É preciso saber ouvir o que a música pede com sensibilidade, pois ela fala baixinho", Victor Chaves. Fonte: do autor (2015).

102 Nas frases "visto minhas canções e ele veste as dele", "depois nos encaixamos nos trabalhos um do outro" e "ele tem o seu estilo", talvez, Victor queira sutilmente "diferenciar" o que é escrito por ele e o que é escrito pelo irmão. O termo "vestir" soa como elemento distintivo, quer dizer, "não tem a mesma característica do que é produzido por mim". Desde que foram para Som Livre (2013), Leo Chaves se tornou o segundo autor das canções da dupla, tarefa antes reservada somente a Victor.
} 
meu irmão e minha paixão"103. Leo (40 anos) é o pai de Matheus (9 anos), Antonio (cinco anos) e José (1 ano), frutos do seu casamento de dez anos com Tatianna Chaves. Victor (41 anos) tem um relacionamento há dois anos com a empresária Poliana Bagatini. Em setembro de 2015, anunciou a chegada da filha primogênita Maria Vitória.

O álbum Viva por Mim (décimo primeiro disco), lançado em 2013, teve o ineditismo de trazer oito das treze canções compostas por Leonardo. Esse CD trouxe outras duas marcas importantes: a gravação foi inteiramente em estúdio (sem o formato acústico ao vivo) e com dois videoclipes na presença de atores nas faixas: Na Linha do Tempo e O Tempo não Apaga: "Foi apenas para diversificar. Queríamos fazer algo que não tínhamos feito antes"104. Indagado se essa renovação de formato fez parte de uma exigência do mercado fonográfico, Victor é bem combatível: "Nunca obedecemos a nenhuma exigência de mercado. Tudo é muito natural. O Leo começou a compor com diversos parceiros e seria natural que suas canções entrassem em nossos trabalhos" ${ }^{\prime 105}$. Na prática, esse estranhamento não aconteceu tanto por esses motivos que Victor acaba de citar. A ida para Som Livre trouxe uma nova apropriação à imagem pública de Leo, que não agradou a todos. O vocalista passou a exibir outros atributos: o corpo apareceu mais malhado e bronzeado, as roupas mais justas, além de acessórios chamativos como chapéus e crucifixos. No capítulo 4, a postura corporal e o empenho cênico do cantor serão examinados detidamente.

Os irmãos nunca se autodeclararam como sertanejos universitários. Evitam até mesmo a nomenclatura sertaneja. Optam pela convergência de rótulos como o folk, pop, música romântica e música sertaneja: "Híbrido é um adjetivo que nos cai bem. Mas acho que o folk seria a prateleira melhor identificável para o nosso som" ${ }^{106}$. Nos Estados Unidos, o folk é uma variante do gênero country music com sonoridades do rock e pop: "Quando as pessoas nos ouviam, uns diziam que o som não era sertanejo, e outros que éramos um novo estilo no sertanejo". Em 2008, foi lançado o primeiro documentário sobre a trajetória artística dos irmãos: Nada És Normal, em língua espanhola. No mesmo ano, fizeram shows em diversas capitais latino-americanas, embora sem um prosseguimento posterior: "Foi muito desgastante. Então paramos no meio. Não dava para conciliar tudo com a agenda do Brasil. Mesmo assim, tivemos resultados excelentes, o que nos rendeu o convite de continuidade e com um

\footnotetext{
${ }^{103}$ Entrevista de Victor Chaves ao autor, 09 de julho de 2015.

${ }^{104}$ Idem, 09 de julho de 2015.

${ }^{105}$ Idem, 09 de julho de 2015.

${ }^{106}$ Idem, 09 de julho de 2015.
} 
lançamento bem maior. Mas recusamos. Nosso tempo já está curto aqui e momento vale mais"107. Victor não disse tudo, afinal, não foi só uma questão de agenda desgastante: o mercado fonográfico latino-americano é desafiador para os artistas brasileiros. São vários os exemplos de fracasso comercial: nos anos 2000, os irmãos pop sertanejos Sandy \& Junior, a cantora Wanessa Camargo (filha de Zezé Di Camargo) entre 2009 e 2013 e, recentemente, Claudia Leitte, após sua apresentação na estreia da Copa do Mundo FIFA de 2014, sediada no Brasil.

Entre 2012 e 2013, Victor e Leo não participaram da renomada Festa do Peão de Boiadeiro de Barretos. Porém, na programação do segundo semestre de 2014, a dupla retornou aos palcos do megaevento do interior paulista. De todo modo, a ausência no "Barretão" por dois anos consecutivos é significativa aos artistas desse gênero. Hoje, o agronegócio e seus subcircuitos culturais (eventos, festas, apresentações etc.) são os principais mantenedores econômicos e culturais da música sertaneja. Embora a consagração nacional, ocorrida entre 2007 a 2012, não tenha dependido exclusivamente desses espaços, não podemos considerá-los como dispensáveis. A partir de 2013, com uma agenda de apresentações e shows por todo o país, tornaram-se figuras frequentes em programas televisivos e radiofônicos de grande audiência, e também viraram garotos-propaganda requisitados pelas principais agências publicitárias brasileiras. Para Piunti, a beleza dos irmãos é um bom atributo mercadológico: "Eles não parecem dois caipiras. São dois caras de influências europeias. A aceitação deles ocorre em lugares mais urbanos, por conta de uma música pouco afetada sentimentalmente, sem aquela coisa da felicidade barata do sertanejo universitário ou do sofrimento dos anos 1990. Eles têm também uma boa imagem e isso conta muito" ${ }^{\prime 108}$.

A carreira foi iniciada em 1992, mas a profissionalização musical só aconteceu em 1994, quando foram cantar e tocar nos bares noturnos da capital mineira. O sucesso fonográfico tardou mais de uma década. No entanto, a experiência como artista de boteco, estrada ou barzinho, ou seja, no espaço dos possíveis ${ }^{109}$ permitiu mais do que um aperfeiçoamento musical e instrumental aos netos do Seu Tonico Chaves: sabiam atender às demandas da indústria fonográfica, pois justamente estiveram por mais de 15 anos à margem

\footnotetext{
${ }^{107}$ Entrevista de Victor Chaves ao autor, 09 de julho de 2015.

${ }^{108}$ Entrevista de André Piunti ao autor, 22 de novembro de 2014.

${ }^{109}$ Cf. BOURDIEU, Pierre. O espaço dos possíveis. In: As Regras da Arte, 1999, p. 265.
} 
dela. Inclusive, atravessaram com êxito a crise discófila e o consumo da pirataria digital. Diferentemente de Sorocaba e de outros sertanejos que apoiariam abertamente tal prática, os irmãos Chaves sempre enalteceram o papel das gravadoras como "parceiras da música profissional". Em 2013, deixaram os estúdios da Sony-BMG e foram para o escritório Som Livre $^{110}$. No mesmo ano, o álbum Viva Por Mim foi o CD mais vendido no Brasil. O selo de uma empresa das Organizações Globo ofereceu aos músicos acesso às trilhas sonoras das novelas produzidas pela Rede Globo e à participação assídua nos programas televisivos da emissora carioca. Esse apoio institucional colaborou para uma carreira menos dependente dos circuitos tradicionais da música sertaneja, uma vez que eles alcançaram um público mais heterogêneo daquele visto em uma festa anual do peão.

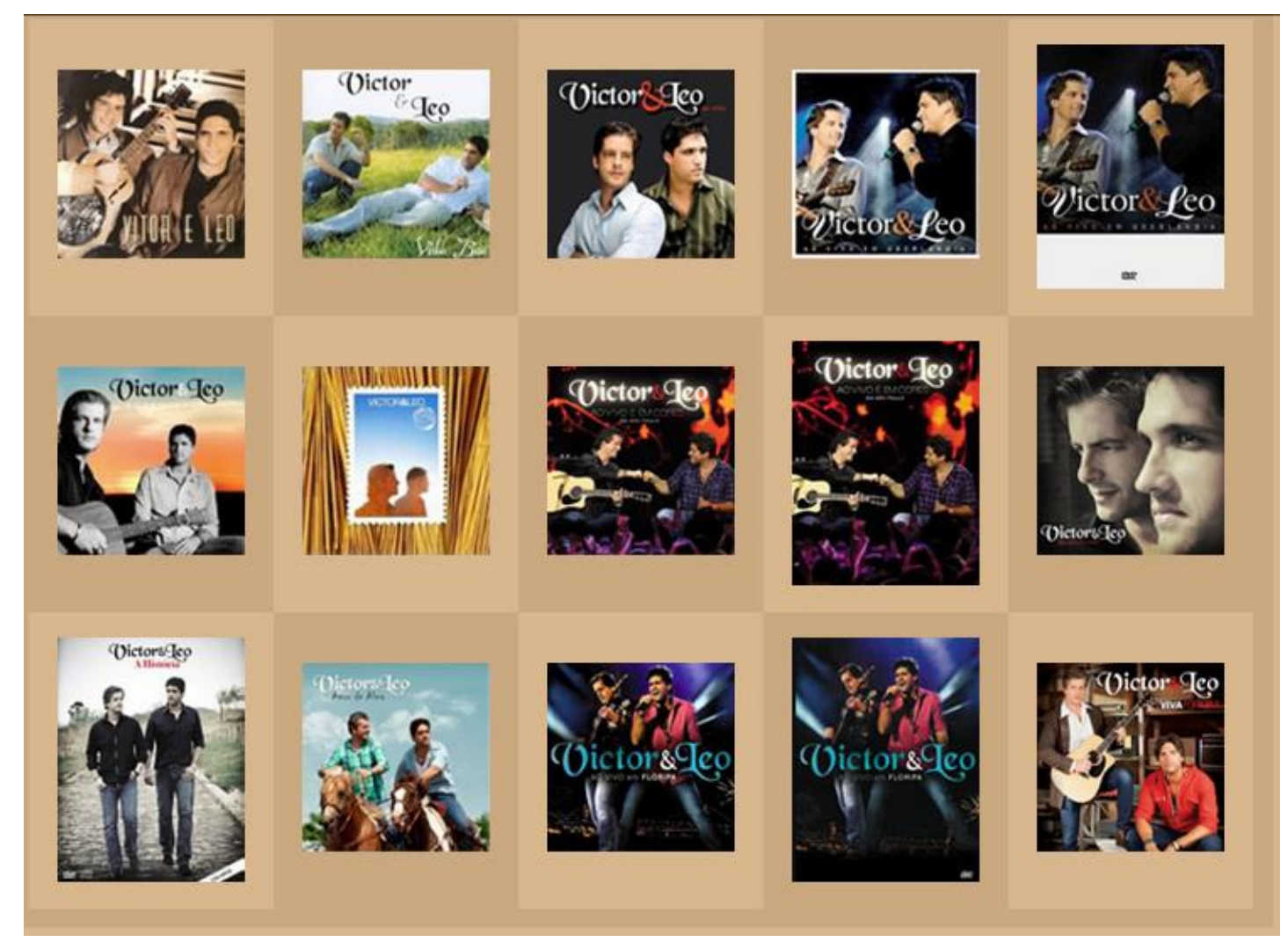

Em 24 anos, a dupla produziu 10 CD's, 4 DVD's ao vivo e 2 Blu-rays, além de dois documentários: Nada És Normal, lançado em espanhol (2008), e Victor \& Leo - A História, lançado em dezembro de 2010. Foto: site oficial da dupla.

Segundo o ECAD - Escritório Central de Arrecadação e Distribuição - órgão responsável pelos direitos autorais das produções musicais no Brasil, entre 2008, 2009 e 2010, Victor Chaves foi o artista que mais arrecadou direitos autorais. De acordo com o portal de

${ }^{110}$ Entre 2007 a 2012, foram contratados do escritório Sony-BMG. 
notícias $U O L^{111}$, Paula Fernandes é a artista que mais regravou músicas de Victor Chaves. Já Sérgio Reis e Chitãozinho e Xororó estão entre os dez artistas que mais regravaram as obras do compositor. O ECAD tem registrado em seu banco de dados 103 obras e 324 fonogramas do $\operatorname{artista}^{112}$ : "Sinceramente, não sei tudo isso. Minha arrecadação maior com a música vem da força com que é cantada na frente do palco. Acho importante que os direitos autorais sejam devidamente repassados e que isso seja cada vez mais de interesse em nosso país, de pontas políticas obscuras, de eleitores desinteressados, de cultura à beira da falência"113. $\mathrm{O}$ posicionalmente político é também compartilhado com o público. No dia 20 de outubro de 2014, véspera do segundo turno das eleições presidenciais, Leo usou a rede social da dupla no Instagram para divulgar duas notas políticas. $\mathrm{O}$ artista apoiou abertamente a vitória do candidato à presidência Aécio Neves (PSDB):

- Faltam seis dias! Como um cidadão brasileiro com certa influência na sociedade, me sinto na obrigação de me pronunciar! Tá na hora, Brasil! Não sou político para pedir voto, mas tenho e exerço o direito me pronunciar e influenciar! Com respeito, é claro, às opiniões contrárias! Reitero com convicção que é necessária a mudança, e a meu ver, ela se chama Aécio Neves! $!^{114}$

- Gente, não quis nesta postagem anterior, me colocar contra ninguém que por qualquer que seja o motivo, tenha outro posicionamento quanto ao voto à presidência! Fui bem claro ao dizer que respeito quem pensa diferente de mim! Posiciono-me como cidadão, que tem exatamente os mesmos deveres e obrigações com relação à sociedade, e segue a mesma constituição que qualquer outro brasileiro! Vou adiante, mediante a necessidade de pensar no futuro dos meus filhos e de qualquer outra criança. Exponho o que penso, pois vejo que vivemos um caos cultural e uma situação muitíssimo precária no ensino escolar e na educação! Nunca tive medo de dizer o que penso, ainda mais quando exerço além do direito de me expressar, o respeito aos que não pensam como eu! Tamô junto moçada! Democracia! Liberdade de expressão! Verdade! Avante Brasil 45! ${ }^{115}$

O sucesso não foi recebido da mesma forma para os dois. Victor sempre apontou uma espécie de inadaptação à fama, citando a depressão e a solidão: “Há coisas do 'Vitor' e do

${ }^{111}$ UOL Música: Paula Fernandes é a artista que mais regravou músicas de Victor Chaves, 10/04/2015.

112 Outras parcerias de Victor e Leo: "Sonhos e Ilusões em Mim” Paula Fernandes; “Ao Vivo em Floripa”, em Florianópolis/SC. O trabalho contou com as participações de Chitãozinho e Xororó, Gabriel Grossi, Haroldo Ferretti, Marciano, Nando Reis, Nice Silva, Paula Fernandes, Pepeu Gomes, Thiaguinho e Zezé Di Camargo e Luciano; "Viva Por Mim" com três participações de renome: Jorge e Mateus, Bruno e Marrone e Almir Sater; DVD "Irmãos" com as participações de Milionário e José Rico, Henrique e Juliano, Malta, Wesley Safadão, Lucyana Villar e Victor Freitas \& Felipe.

${ }^{113}$ Entrevista de Victor Chaves ao autor, 09 de julho de 2015.

${ }^{114}$ Instagram oficial da dupla.

${ }^{115}$ Instagram oficial da dupla. 
'Victor', mas não sei quantizar. Hoje vivo melhor com isso. Nunca busquei a fama e ela atrapalha minha vida um pouco, no sentido de que você sai do lugar de observador e passa a ser observado. Enfim, vou me adaptando" 116 . Nos últimos anos, a imprensa tem registrado o desgaste pessoal enfrentado pelo compositor e aposta em uma possível carreira solo para Leonardo. "Eu não vejo problema nisso. Muita gente questiona isso como se fosse um grande problema. Problema é não ser feliz e perder a saúde. Se algum dia, um dos dois não estiver feliz na parceria, melhor ficarmos apenas como irmãos. Não quero meu irmão infeliz comigo, se ele não desejar fazer uma música que bata com o que tenho a oferecer. Eu o amo, então, essa coisa de ter que ficar juntos não funciona" ${ }^{\text {117 }}$. Enquanto os acompanhava na pesquisa de campo $^{118}$, ouvi algumas queixas das fãs que não eram recebidas nos camarins dos shows. Elas aguardavam por horas a fio a saída de seus ídolos pelo estacionamento e citavam um comportamento "esnobe" de Victor, que nunca descia de seu automóvel para atendê-las somente Leonardo o fazia. Para o compositor sertanejo:

Artista faz arte. Ele existe no palco, no estúdio, tocando, cantando e compondo. Atender às pessoas pessoalmente é outra coisa, e não se trata de uma obrigação. Permito-me fazer isso quando posso e quando quero. Atendemos muitas pessoas em cada show no camarim. Tem gente que diz: 'não comprarei seu $\mathrm{CD}$, porque você não parou o carro na saída do show para me cumprimentar'. Mas eu não quero vender arte por ter de atender a caprichos pessoais de quem se acha mais fã do que outros. Que ouçam a minha arte quem se sentir bem com ela. Vez e outra, eu até paro e atendo gentilmente a todos, mas não por obrigação ${ }^{119}$.

Mais uma vez, o "poeta" caipira traz à tona a "pureza romântica" da figura social do artista e invoca a autonomia do artista comprometido somente com sua arte, que não deve atender aos anseios de seu público-consumidor. O estudo de Mozart realizado por Norbert Elias $^{120}$ ou o de Flaubert feito por Pierre Bourdieu ${ }^{121}$ contribuiu para que meu olhar ainda inexperiente não naturalizasse tais categorias artísticas, sem antes desconstruí-las.

\footnotetext{
${ }^{116}$ Entrevista de Victor Chaves ao autor, 09 de julho de 2015.

${ }^{117}$ Idem, 09 de julho de 2015.

${ }^{118}$ Estive em quatro apresentações: Terra Country Interlagos (agosto de 2014), Espaço das Américas (outubro de 2014), Citibank Hall (dezembro de 2014) e na gravação do DVD Ao Vivo Irmãos (janeiro de 2015).

${ }^{119}$ Idem, 09 de julho de 2015.

${ }^{120}$ ELIAS, Norbert. Mozart, Sociologia de um Gênio. Rio de Janeiro: Zahar, 1995.

${ }^{121}$ BOURDIEU, Pierre. As Regras da Arte: Gênese e Estrutura do Campo Literário. São Paulo: Companhia das Letras, 1992.
} 
Nas revistas e jornais consultados, a valorização da tradição e da autenticidade musical é uma espécie de mantra no discurso do músico. No cenário atual, Victor Chaves chega a falar em prostituição do sertanejo: "Vejo a música sertaneja mal interpretada e sem identidade. Apesar de ser uma música com uma história linda, que as pessoas deveriam tentar conhecer. Mas hoje, pelo capitalismo, pelo dinheiro, ela vai perdendo um pouco dessa identidade. É muito fácil você dizer que é sertanejo. No entanto, na minha opinião, é um momento de prostituição absoluta do gênero sertanejo" ${ }^{122}$. Essa crítica à "prostituição" da música sertaneja não é novidade. Em Acorde na Aurora: Música Sertaneja e Indústria Cultural, o sociólogo Waldenyr Caldas chega a dizer que: "a nova dupla sertaneja que pretende sucesso, que precisa sobreviver, prostitui-se profissionalmente, aceitando passivamente as condições oferecidas pelo agenciador" ${ }^{\prime 123}$. O livro Acorde na Aurora foi publicado em 1977, portanto, é curioso notar que, quase quarenta anos depois, tal substantivo (prostituição) ainda circule, até mesmo, entre os novos músicos sertanejos. Talvez, a prostituição "denunciada” por Waldenyr Caldas e Victor Chaves seja apenas um sinônimo de êxito comercial à custa de negociação mercadológica entre artista e indústria fonográfica. E, quem não faz uso disso? Independentemente do gênero, o artista que quer o selo do sucesso se submete as regras do jogo. Isso também vale para os irmãos, caso contrário, o dueto Victor \& Leo Chaves sequer existiria. Posteriormente, o compositor mineiro procuraria amenizar a controvérsia de que o "gênero sertanejo vai de mal a pior" usando como exemplo sua própria produção musical:

Acho que o gênero sertanejo, se ele existe, vai de mal a pior. Talvez seja um dos gêneros menos explorados atualmente. Acho que a música sertaneja é a menos ouvida no país. Se você disser, 'Na linha do tempo', que está em primeiro lugar nas rádios, não é música sertaneja. Se alguém disser: 'ah, é música sertaneja evoluída', não, não é. É música romântica pop. Isso tem que ser assumido. Aquilo que traz o sertão e tem uma vestimenta da viola caipira, ou do violão rasqueado, do caboclo, essas coisas todas misturadas, formaram um gênero chamado sertanejo. E depois as duplas vieram cantando outras coisas. Ou continuaram com o romantismo, mas cantando outras coisas, pop, rock, soul. Somos tudo isso, essa mistura. Mas, a gente não tira o pé do sertão e sempre mantemos alguma coisa na vertente ${ }^{124}$.

A confluência do sertanejo com certos tipos de ritmos, como é o caso funk, não é apreciada pelos dois. Chegam a comparar funknejo ${ }^{125}$ a "misturar café com gasolina", mas

\footnotetext{
${ }^{122}$ R7Entretenimento: Com críticas ao sertanejo atual, Victor e Leo lançam o DVD mais dançante da carreira, 26/07/2012.

${ }^{123}$ CALDAS, 1977, p.42.

${ }^{124}$ IG Sertanejo: Victor Chaves: “Acho que o gênero sertanejo, se ele existe, vai de mal a pior”, 13/12/2013.

${ }^{125}$ G1/Globo: Victor e Leo comparam funknejo a "misturar café com gasolina”, 30/07/2013.
} 
outros gêneros são bem-vindos e bem-aceitos na música sertaneja: abusam da sonoridade do rock e do pop ${ }^{126}$. Ganhadores do Grammy de 2014 - maior premiação da música mundial, Victor e Leo criticaram a atual "falta de originalidade" do gênero: "Houve um tempo em que tínhamos referenciais de maior conteúdo. Em nível intelectual mesmo. Interpretação de texto e figuras de linguagem. Acho que a grade escolar vem piorando, então piora também o nível de absorção geral. Não estou me colocando em uma categoria superior, mas tem cara que é considerado cantor hoje que não entraria em um estúdio de rádio anos atrás. É tudo questão de referencial" ${ }^{\text {127 }}$. No programa Globo Rural ${ }^{128}$, o jornalista José Hamilton Ribeiro ${ }^{129}$ levantou duas questões aos irmãos: o quanto traziam de música caipira na bagagem e se eles estavam "traindo a música caipira". Leonardo respondeu a primeira questão: "Não fazemos, definitivamente, uma música pensando só no intuito comercial. O objetivo não é só esse, mas tem que se pensar nisso também. Se quisermos fazer parte desse movimento, temos que nos preocupar com isso. A música caipira vem da nossa infância. Crescemos em contato com o campo, com as fazendas e com gado. Parece que isso nos pegou. Está na veia. Eu e o Victor somos bem mais caipiras fora do palco do que em cima dele"130. Victor complementou: "Música caipira é minha mãe. Então, enquanto filho dela, a música que eu fizer virá dela"131. No início, os irmãos pareciam ter uma postura menos ideológica. Gostavam de frisar as origens sociais humildes e pouco participavam desse debate estético dentro da música sertaneja. Publicamente, eram até discriminados com rótulos como bregapop ${ }^{132}$ : "Não olhamos para isso. O preconceito não é conceito. Sempre fizemos o nosso som e ponto. Até porque fomos aceitos em muitos meios e festivais que jamais estariam abertos ao gênero. Acho que tiveram um pouco de preconceito, mas não estamos nem um pouco interessados"133.

${ }^{126}$ R7 Entretenimento: Victor e Leo lançam música com sonoridade rock e comentam o atual momento do sertanejo, 25/11/2014.

127 Jovem Pan: Ganhadores do Grammy, Victor e Leo criticam falta de originalidade na música, 10/12/2013.

${ }^{128}$ Participação de Victor e Leo no aniversário de 35 anos do programa: Novas duplas de sertanejo moderno preservam as raízes do campo: "Música sertaneja é um negócio que rende milhões de reais por dia. Das 100 músicas mais tocadas nas rádios, 59 são do novo estilo sertanejo", exibido em 11/01/2015.

${ }^{129}$ Cf. RIBEIRO, José Hamilton. Música caipira: as 270 maiores modas de todos os tempos. São Paulo: Globo, 2006.

${ }^{130}$ Entrevista de Leonardo Chaves ao programa Globo Rural, 11/01/2015.

${ }^{131}$ Entrevista de Victor Chaves ao programa Globo Rural, 11/01/2015.

${ }^{132}$ Revista Gloss: Bregapop: Victor e Leo abrem as porteiras da música sertaneja, viram ídolos de mulheres de vários perfis e vendem CD's a rodo. E ainda são lindões, 07/12/2009.

${ }^{133}$ Entrevista de Victor Chaves ao autor, 09 de julho de 2015. 
Presentemente, a dupla mantém uma carreira sólida no cenário musical brasileiro. Já venderam mais de 1.750.000 cópias de CD's e 700 mil cópias de DVD's. Receberam cinco discos de platina pelos CD's: Borboletas (três vezes platina, com 300 mil cópias vendidas), 2008; Amor de Alma (120 mil cópias), 2011; Viva por Mim (100 mil cópias), 2013. Pelos álbuns ao vivo, conquistaram seis discos de platina: Victor \& Leo Ao Vivo (duas vezes platina, com 200 mil cópias), 2006; Ao Vivo em Uberlândia (três vezes platina, com 300 mil unidades), 2007; Ao Vivo e em Cores em São Paulo (100 mil discos vendidos), 2009; e dois discos de ouro: Ao Vivo em Floripa (50 mil cópias), 2012; e Irmãos (50 mil cópias), 2015. Na última semana de outubro de $2014^{134}$, Victor e Leo atingiram dois consideráveis patamares na cena musical: assumiram o primeiro lugar de execução nas rádios brasileiras, por treze semanas consecutivas (ANEXO A) e foram condecorados com um disco de platina (100 mil cópias) pelo álbum Viva por Mim, o mais vendido no mercado fonográfico de 2013 (anunciado em 2014). Uma vendagem alta nos dias de hoje para um mercado discográfico em crise, que se vê obrigado a competir com as novas plataformas de distribuição e consumo digitais $^{135}$. A dupla tinha muito a comemorar: também venceram o maior prêmio da música mundial, levando o Grammy Latino ${ }^{136}$ de "Melhor Álbum de Música Sertaneja", com o DVD Ao Vivo Em Floripa, de 2012. O álbum Viva Por Mim foi o primeiro trabalho produzido nos estúdios Som Livre (contratados em julho de 2013). A gravadora divulgou vigorosamente o novo disco, promovendo-o nos programas radiofônicos e televisivos de norte a sul do Brasil, sobretudo, nos canais e emissoras afiliados à Rede Globo (uma das muitas empresas conglomeradas das Organizações Roberto Marinho). Inclusive, tiveram a música Tudo Com Você na trilha sonora ${ }^{137}$ da novela global Alto Astral. Sem dúvidas, essa nova parceria institucional abriu espaço midiático a Victor e Leo.

$\mathrm{O}$ rádio e a TV continuam sendo importantes meios de comunicação para a consagração do gênero. O sertanejo domina a programação nas rádios como aponta Helder

\footnotetext{
${ }^{134}$ O monitoramento de Victor e Leo e Fernando e Sorocaba foi encerrado no dia 29 de dezembro de 2014. A Crowley não enviou mais os rankings radiofônicos, e o ECAD já fechou os registros fonográficos de 2014. Nas redes sociais, os artistas estão apenas fazendo retrospectivas do ano, sem informações novas. Não há mais apresentações em TV, rádio ou shows.

${ }^{135}$ Pouco a pouco, as parcerias com os serviços digitais como iTunes e Spotify (serviços legais de distribuição de músicas na internet) estão aumentando, permitindo novas apropriações de consumo musical.

${ }^{136}$ Entre 2008 e 2015, eles receberam sete indicações ao prêmio, mas a premiação só chegou em 2013.

137 Temas de novela (em ordem cronológica): Em 2008: "Borboletas" fez parte da trilha sonora da novela Revelação do SBT; "Tem que Ser Você" da novela Favorita, da Rede Globo. Em 2009: "Deus e Eu no Sertão" e "Nada Normal", da novela Paraíso (Rede Globo). Em 2010: "Rios de Amor", da novela Araguaia. Em 2011: "Não Precisa", da novela Morde e Assopra. Em 2012: "Não Mais", da novela Corações Feridos, do SBT. Em 2015: "Eu Vim Pra Te Buscar", da novela Malhação.
} 
Maldonado. Por meio dos índices de monitoramento Crowley, o jornalista faz uma oportuna conclusão: comercialmente, o sertanejo é o mais rentável, hoje, no Brasil:

\begin{abstract}
Nos últimos 14 anos, o sertanejo foi o gênero que mais ganhou notoriedade na execução em rádios, enquanto a MPB se transformou num dos gêneros menos ouvidos no país. As músicas sertanejas foram executadas 838 mil vezes (nas emissoras auditadas pela empresa), enquanto a MPB teve menos de seis mil execuções. Não é novidade que o sertanejo dominou as paradas de sucesso nos últimos anos. Hoje, $60 \%$ da programação das rádios são reservadas à música sertaneja. Em 2013, foram 838 mil execuções de faixas sertanejas contra 625 mil dos gêneros restantes. Em raros mercados, observa-se tamanho domínio de determinado estilo musical. Não à toa, quase todas as cidades do país contam anualmente com pelo menos uma grande festa, feira ou festival sertanejo ${ }^{138}$.
\end{abstract}

Entretanto, as mídias sociais compõem um novo suporte à carreira dos músicos sertanejos. As redes sociais Facebook, Instagram e Twitter são importantes canais de divulgação e interação com o público. Investe-se muito dinheiro para atrair seguidores que compartilhem as fotos, agendas dos shows, bastidores e um sem-número de cenas cotidianas dos artistas. Especialmente hoje, o Facebook é a principal plataforma de divulgação das duplas pequenas. Fernando e Sorocaba e Victor e Leo sabem disso, e todos eles possuem conta oficial nesses veículos. Os fãs sentem-se mais aproximados de seus ídolos, e menos dependentes de mediadores, embora os responsáveis pelas publicações de conteúdo sejam os assessores de imprensa, raramente os músicos em si. Um exemplo clássico desse rearranjo entre produtores e consumidores são os "teasers". Notadamente, Leonardo faz bastante uso dessa prática. A coletânea Perfil foi lançada em outubro de 2014 pelo selo Som Livre. Desde o período de produção do álbum, em meados de setembro, Leo procurou instigar o público, mobilizando o Facebook e Instagram com pequenos trechos (ou "teasers") da nova música em estúdio. Funcionou como uma espécie de chamariz, que atiçou a curiosidade das fãs mais desvairadas. No mesmo ambiente digital, são promovidas espécies de "concursos culturais" entre as seguidoras. Quem escrever uma frase original, por exemplo, pode conseguir entrada gratuita ou acesso ao camarim no próximo show, "uma tarde" em companhia do artista em determinada emissora de rádio ou televisão, brindes promocionais etc. Existe um quadro técnico e especializado cada vez maior nos escritórios administrativos dos músicos somente para gerenciar os conteúdos digitais. Nos dias atuais, tanto os produtores culturais quanto as instituições fonográficas envolvidas com o gênero sertanejo não deixam escapar quase nenhum segmento possível que possa beneficiá-los comercialmente.

\footnotetext{
${ }^{138}$ Portal do Sucesso: sertanejo domina programação das rádios, 20 de maio de 2014.
} 


\section{A moda sertaneja no estilo empreendedor}

Na década de 1990, a crise no mercado discófilo brasileiro, até então, não impediu o sucesso comercial e econômico da música sertaneja - privilégio esse, compartilhado somente com o gênero axé music baiano. No entanto, nessa mesma época, os artistas sertanejos passaram a apostar em outros negócios lucrativos bem longe da música. Ícones do sertanejo romântico como Zezé Di Camargo e Luciano ${ }^{139}$, Chitãozinho e Xororó ${ }^{140}$ e Leonardo ${ }^{141}$ fizeram bons investimentos financeiros na pecuária, no ramo imobiliário e na gastronomia. No início dos anos 2000, Marrone ${ }^{142}$ (parceiro de Bruno) e Fabiano ${ }^{143}$ (da dupla musical Cesar Menotti e Fabiano) - cantores da entressafra do sertanejo romântico para o sertanejo universitário - seguiram os mesmos passos. Atualmente, João Bosco ${ }^{144}$ (do dueto João Bosco e Vinicius), Marcos e Belutti ${ }^{145}$, Gusttavo Lima ${ }^{146}$ e Michel Teló ${ }^{147}$ também abraçaram a prática empreendedora. Sem dúvida alguma nessa lista um nome se destaca: Sorocaba. Fernando Fakri de Assis tem alma de empresário ${ }^{148}$. O artista já teve em seu elenco até jogadores de futebol, como por exemplo, o atacante Victor Andrade que, até 2016, atuou no

\footnotetext{
${ }^{139}$ Os irmãos são sócios em um projeto imobiliário. Zezé é dono também da fazenda $E$ o Amor, onde cria vacas, bois e gado Nelore. O último leilão do cantor, que aconteceu no final de outubro de 2015 , fechou com $\mathrm{R} \$ 4,5$ milhões em vendas. Fonte: Portal Ego/Globo: Sorocaba, Marrone e mais sertanejos têm negócios fora da música, $30 / 11 / 2015$.

${ }^{140}$ É uma das duplas sertanejas mais milionárias, com investimentos há três décadas na pecuária e donos da franquia Montana Grill, com lojas espalhadas por todo o país. Fonte: Portal Cidade Verde: Descubra como os sertanejos milionários investem a grana, 07/11/2014.

${ }^{141}$ Leonardo foi um dos cantores do gênero que mais vendeu discos nos anos 1990 e 2000 . Atualmente, é dono da produtora Talismã, que gerencia carreiras de outros artistas sertanejos como Eduardo Costa. Foi empresário de Paula Fernandes até 2012.

142 Proprietário da Churrascaria Favo de Mel, restaurante homônimo de um dos grandes hits de Bruno e Marrone. É também sócio da Woods Goiânia, franquia de casas noturnas sertanejas.

${ }^{143}$ Fabiano é sócio do restaurante japonês Tokyo Sushi Lounge em Belo Horizonte (MG).

144 O cantor tem investido no ramo gastronômico e mantém uma rede de paleterias, a Mexicoletas, em seis cidades: Uberaba, Palmas, Goiânia, Brasília, Uberlândia e Ribeirão Preto.

${ }^{145}$ Os irmãos são sócios do restaurante Estação Leopoldina Parrilla, em São Paulo e São Bernardo do Campo.

${ }^{146}$ Gusttavo Lima é sócio de uma equipe de Fórmula Truck (competição entre caminhões) e investe em imóveis e terras nas cidades mineiras de João Pinheiro e Pato de Minas.

${ }^{147}$ Michel Teló é dono de uma fazenda de 14 mil hectares em Corumbá (MS), de uma construtora em Campo Grande (MS) e de uma editora de músicas chamada Pantanal.

${ }^{148}$ Portal Cidade Verde, 07/11/2014.
} 
time Benfica de Portugal. Segundo o jornalista musical André Piunti ${ }^{149}$, Sorocaba é o maior case de sucesso do gênero. Seu primeiro investimento nesse seguimento foi como empresário do astro milionário teen da música sertaneja Luan Santana (2006-2013). De lá para cá, Sorocaba vem construindo um verdadeiro império sertanejo ${ }^{150}$. Na atualidade, ele é o responsável por coordenar inúmeras empresas que atuam em diversos ramos da indústria da cultura e do entretenimento. Mas esse é o tema do próximo capítulo.

Em 2015, curiosamente, outro personagem do show business sertanejo tem disputado tal status empreendedor: Leonardo Chaves. Desde 2007, a rivalidade entre Victor e Leo e Fernando e Sorocaba não tem trégua, dentro e fora dos palcos. Concorrência que, aliás, não está restrita somente à arrecadação de direitos autorais ou à autenticidade dos estilos musicais. Para além da competição simbólica e mercadológica entre os dois duetos, há também um conjunto de padrões e afinidades muito compartilhadas entre Sorocaba e Leo Chaves. Uma dessas práticas em comum tem se destacado notadamente nos últimos anos: a construção de um arquétipo do sertanejo empreendedor. Na realidade, essa síntese do artista-empresário não é nenhuma novidade na história social da música sertaneja. Nos dias de hoje, esse papel dúbio é bem desempenhado por Sorocaba. Fernando Fakri de Assis "Sorocaba", no entanto, não é o único a personificar tal figura. $\mathrm{O}$ ingresso de Leonardo Chaves nesse time ainda é recente. Depois que ele e Victor foram para o escritório do Grupo Globo, em 2013 (selo Som Livre), o formato inicial da dupla sertaneja não é mais o mesmo. Enquanto o irmão e parceiro musical quer distância dos holofotes, o protagonismo foi bem aceito por Leo. A revista Forbes ${ }^{151}$ trouxe um título bem ilustrativo dessa dupla atuação do músico: Leo Chaves, o cantor sertanejo dos negócios ${ }^{152}$.

$\mathrm{Na}$ abertura, a reportagem da jornalista Beatrice Teizen traça o perfil multifuncional do sertanejo: "Empresário, produtor, compositor, fazendeiro, atleta, cantor e pai de família.

\footnotetext{
${ }^{149}$ Entrevista de André Piunti ao autor, 22 de novembro de 2014.

150 "Sorocaba também é um dos compositores que mais arrecadam com direitos autorais. O artista chega a faturar mais de R \$ 500 mil por ano como compositor musical. Além disso, ele é dono do escritório FS, que se responsabiliza pelas carreiras de gente como Thaeme e Thiago e Marcos e Belutti (dos quais detém até 30\% da receita). E, para finalizar, ainda é sócio em algumas casas da rede de baladas sertanejas Woods". Fonte: Portal Cidade Verde, 07/11/2014.

${ }^{151}$ Revista de negócios e economia que, tradicionalmente, publica todos os anos duas listas com os nomes das personalidades mais poderosas ou bilionárias do mundo.

${ }^{152}$ Revista Forbes: Leo Chaves, o cantor sertanejo dos negócios, 30/08/2015.
} 
São várias as facetas de Leo Chaves [...]. Hoje, aos 38 anos, tem uma série de projetos fora do mundo da música, que muitas pessoas ainda não conhecem, e a palavra que mais o define é a versatilidade". Por muito tempo, essa "versatilidade" foi atribuída somente ao seu concorrente. Em 2012, a revista $G Q$ fez o mesmo retrato de Sorocaba - portanto, quase quatro anos se passaram até que Leo divulgasse abertamente à imprensa e ao seu público tais projetos fora da música. Esse intervalo de tempo não foi mera coincidência. Em novembro de 2014, Fernando e Sorocaba anunciaram o desligamento com o selo Som Livre, e os músicos foram para o escritório particular de Sorocaba, a FS Produções Artísticas. Na época, os sertanejos até admitiram publicamente que: "Não tem mais pressão para não soltar música" 153. Em outras palavras, as regras da gravadora do Grupo Globo vetavam as estratégias de mercado de Sorocaba. Hoje em dia, as gravadoras são bem menos mandatárias, mas seu formato tradicional ainda não é totalmente dispensável para maioria dos artistas. Sorocaba é uma das poucas exceções. $\mathrm{O}$ artista não depende da venda de discos para manter-se no topo o produto está no show e não na venda de álbuns ${ }^{154}$. O cenário para Victor e Leo é outro. Em julho de 2013, os irmãos mineiros deixaram a gravadora Sony-BMG e foram para Som Livre. O primeiro álbum, Viva por Mim (2013), vendeu mais de 200 mil cópias e foi o CD mais vendido no Brasil naquele ano. O DVD Irmãos (2015) fez arrecadação idêntica à venda de 2013. Em quinze $\operatorname{anos}^{155}$ de carreira profissional, a dupla sertaneja vendeu mais de dois milhões de cópias. Vale a pena destacar que Victor e Leo também dependem quase que exclusivamente das cifras pagas pelos contratantes dos shows. Porém, em oposição a Sorocaba, eles saem em defesa da comercialização legal ${ }^{156}$ dos discos e DVD's para o grande público, e assim, os irmãos são bem-vistos e foram bem-vindos pelo Grupo Globo. Se um dia Sorocaba fez parte do elenco Som Livre, hoje, à frente da FS Produções Artísticas, o artista/empresário é o maior concorrente de mercado de Victor e Leo, mas também das Organizações Globo de Roberto Marinho. Não foi à toa que as instituições ligadas a Globo têm investido tanto em uma atualização da imagem pública de Leonardo Chaves. A figura do

\footnotetext{
${ }^{153}$ IG Sertanejo: Fernando e Sorocaba saem da gravadora e lançam selo próprio: "Não tem mais pressão para não soltar música", 29/11/2014.

154 “Graças a Deus. Estamos muito felizes. Não que antes não estivéssemos, mas existia uma pressão da gravadora, que tem algumas regras de bolo que muitas vezes não se encaixa tão bem para nosso mercado. A gente decidiu estrategicamente experimentar. Mas temos artistas de nosso escritório que estão em gravadora e estão muito bem". Fonte: IG Sertanejo, 29/11/2014.

${ }^{155}$ Nesse mesmo tempo de atividade musical, Zezé Di Camargo e Luciano venderam 22 milhões de discos.

${ }^{156}$ Isso não quer dizer que Fernando e Sorocaba promoveram o consumo pirata. Eles defendiam o acesso livre às músicas disponibilizadas na internet para o público.
} 
músico humilde e simples, que um dia trouxe a adesão popular, cada vez mais tem cedido espaço para um showman sertanejo:

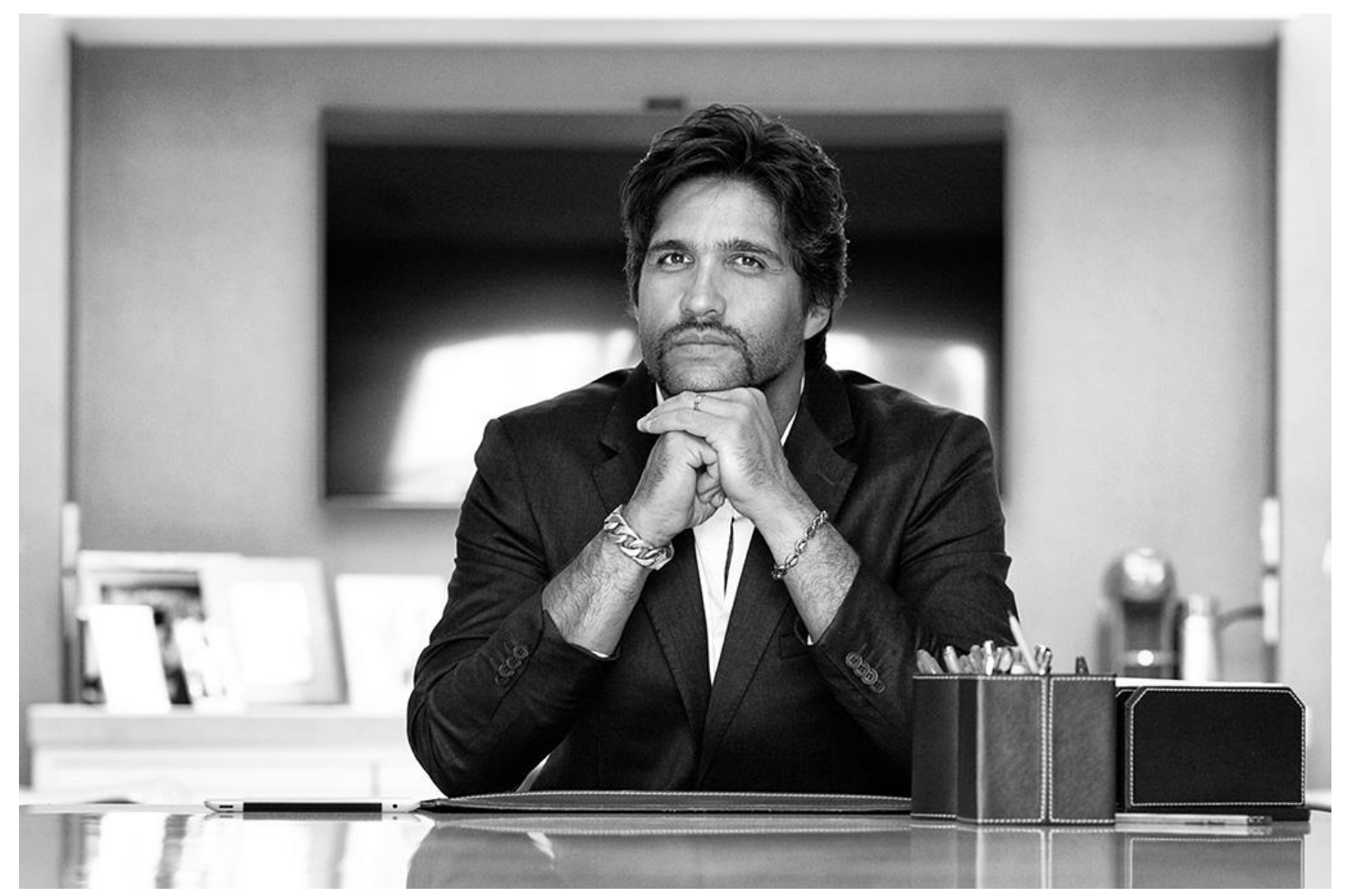

Se no palco sertanejo Leonardo Chaves sabe interpretar o papel do artista virtuose, fora dele o músico tem protagonizado outros personagens: o patriarca exemplar, o atleta-modelo, o fazendeiro refinado e também o talentoso empresário. Leo tem uma personalidade versátil que o torna convincente em todas essas funções. Nos negócios, o músico empreendedor tem atuado nos ramos da pecuária, no setor imobiliário e na produção de outros artistas no show business: "Sempre tive essa característica de criação, de empreender e ter ideais voltadas a objetivos dentro de um universo dos negócios. Esse meu lado veio crescendo à medida que eu e meu irmão nos tornávamos mais conhecidos. Trabalhar nesses meios fora da música me agrada muito, é algo que me preenche", disse o cantor à Forbes. No retrato, a fotografia em preto e branco transmite uma áurea sóbria à imagem jovial do cantor. As mangas curtas do sofisticado terno de linho dão destaque às duas pulseiras de ouro, ao mesmo tempo em que os botões entreabertos suavizam a austeridade do traje. Leo apoia os cotovelos na mesa e eleva os pulsos cerrados até a altura da mandíbula, e assim o queixo quadrado e viril é realçado junto ao desenho do cavanhaque. O visual do cabelo é despojado, com fios repicados e levemente acinzentados. No olhar a revelação de um homem vaidoso, ambicioso, destemido e perspicaz que sabe encarar cada oportunidade de sucesso. Eis o retrato do sertanejo empreendedor. Fonte: Revista Forbes (agosto de 2015). Foto: Cesar Dutra.

Leonardo Chaves é dono de duas fazendas; uma no estado do Pará e a outra na cidade de Uberlândia (MG). Há pouco tempo, tornou-se criador de gado senepol: "É uma raça que vem ganhando espaço e respeito entre os criadores de outras espécies, por se adaptar muito 
bem ao clima tropical" ${ }^{\text {157 }}$. Outro projeto em desenvolvimento é a abertura de uma rede de franquia de leilões, a Leilões Paraíso. Leo quer levá-la até as cidades dos clientes investidores: "É algo inédito ainda. Eu também costumo ir a leilões, e o fato de pertencer à dupla [sertaneja] Victor e Leo ajuda bastante a divulgar nossa marca" ${ }^{\text {158 }}$. Embora a marca "Victor e Leo" beneficie os empreendimentos de Leonardo, Victor nunca participou diretamente de nenhum deles. Se hoje, o slogan da dupla sertaneja oferece prestígio aos negócios de Leo, no passado, tal consagração foi penosa e à custa de mais de 15 anos de estrada, nos bares e casas noturnas do sul de Minas e da capital paulistana. Entre 2006 e 2007, apesar do estrondoso sucesso nacional, o dueto mostrava-se modesto. Os irmãos orgulhavamse e se emocionavam ao citar o avô Tônico, a difícil trajetória musical, as relações de cumplicidade e irmandade e, sobretudo, o projeto de revalorização da música sertaneja/caipira autêntica.

Sorocaba surgiu nesse mesmo cenário. Foi o maior concorrente de mercado dos dois, mas nunca levantou tais bandeiras. O artista/empresário não se mostrou indisposto ao ser rotulado como sertanejo comercial. Porém, tanto para Victor quanto para Leo, a tradição sempre foi defendida fervorosamente. Em 2014, o programa Globo Rural ${ }^{159}$ os anunciou como aqueles que "conservam o velho formato de dupla, e em geral, não se esquecem da sua origem e nem de onde vem o seu sucesso" $" 160$. Logo na abertura da reportagem, Victor manteve o tradicional discurso: "Música caipira é a minha mãe. Então, enquanto filho dela, a música que eu fizer virá dela. Vou continuar assim". Por sua vez, Leonardo não quis ser tão ortodoxo quanto o irmão: "Eu e o Victor não fazemos, definitivamente, uma música pensando só no intuito comercial. O objetivo não é só esse, mas tem que se pensar nisso também. E de certa forma se a gente quiser fazer parte desse movimento tem que se preocupar um pouco com isso também"161. A ida para Som Livre (2013) trouxe uma série de divergências artísticas e comerciais à carreira musical dos dois. Enquanto Victor negou se curvar aos interesses da

\footnotetext{
${ }^{157}$ Revista Forbes: Leo Chaves, o cantor sertanejo dos negócios, 30/08/2015.

${ }^{158}$ Idem, agosto de 2015.

${ }^{159}$ Globo Rural: Novas duplas de sertanejo moderno preservam as raízes do campo, 11/01/2015.

${ }^{160}$ José Hamilton Ribeiro é um feroz defensor da "autêntica" música caipira/sertaneja. O apreço do jornalista pela dupla foi notável: "A demanda por apresentações de Victor \& Leo em todo país tem sido tão intensa que, se quisessem, poderiam fazer um show por dia. Depois de batalhar por 15 anos, cantando em barzinhos, vivem hoje um reconhecimento que não é só do público, mas também de músicos e colegas. Suas músicas misturam o gênero pop com uma pitada de sertanejo-raiz [vídeo de Deus e Eu no Sertão]”. Fonte. Idem, 11/01/2015.
}

${ }^{161}$ Globo Rural: Novas duplas de sertanejo moderno preservam as raízes do campo, 11/01/2015. 
gravadora, Leo os abraçou de bom grado. No capítulo 4, a indisposição teatralizada nos palcos pelos dois irmãos será contextualizada a rigor, pormenorizando assim, os atuais conflitos de interesses existentes ali. Ultimamente, Leonardo tem personificado o mesmo protótipo do sertanejo empreendedor de Sorocaba - um estereótipo comercial similar ao censurado por ele mesmo em um passado recente.

Na reportagem para a revista Forbes, Leo ainda citou outro empreendimento inédito: a compra de uma península a 35 quilômetros de Uberlândia para loteamento de 12 chácaras de alto padrão: "Estamos acordando com investidores e firmando parcerias. Águas do Paraíso será algo nunca visto no Brasil. É realmente incrível. Lá será feito um condomínio luxuoso, em torno de uma represa de água muito limpa, onde é possível andar de barco, nadar e praticar esportes" ${ }^{\prime 62}$. Mas, nessa empreitada, o público-alvo está longe de ser o mesmo daquele visto em um show da dupla. Nos espetáculos ou nas redes sociais, Leo se mostra muito disposto a compartilhar e a reproduzir seus próprios padrões normativos. O cantor sempre defende que a prática esportiva, a valorização da família tradicional, a glorificação de uma crença espiritual e o enobrecimento das atividades trabalhistas são os pilares fundamentais para uma existência prazerosa e saudável. No entanto, quem deseja tal qualidade de vida precisa de um lugar apropriado para usufruí-la, e é claro que o luxuoso condomínio Águas do Paraíso é um desses espaços que pode oferecer todos esses benefícios mas que está reservado apenas para 12 famílias abastadas. Desse modo, o sertanejo empreendedor habilmente reconhece que o público-alvo para os negócios não é o mesmo daquele público pagante dos seus shows - aliás, plateia que, na prática, é a responsável por seu enriquecimento.

Vale a pena ressaltar que esse retrato empresarial do artista é uma criação recente, sendo somente divulgado a partir de 2015. A essa altura, Victor e Leo completavam dois anos de contrato assinado com o selo Som Livre. Entretanto, desde 2014, Victor não fazia questão alguma de esconder sua insatisfação com os rumos da carreira ${ }^{163}$. Não foi à toa que a gravadora adotou a estratégia de oferecer maior protagonismo a Leonardo. No pior dos cenários, caso Victor se desligasse do Grupo Globo, Leonardo estaria pronto para prosseguir

\footnotetext{
${ }^{162}$ Revista Forbes: Leo Chaves, o cantor sertanejo dos negócios, 30/08/2015.

163 Em 2014, registrei três shows da dupla em São Paulo: Terra Country Interlagos (agosto), Espaço das Américas (outubro) e Citibank Hall (dezembro). As fãs que acompanhei informalmente me disseram que Victor não era mais o mesmo. Naquele ano, os episódios de indiferença com o grande público e de atrito com a imprensa se tornaram corriqueiros. Até no palco, Victor não disfarçava o bate-boca com o irmão. Nas saídas dos shows, não era incomum encontrar o compositor embriagado.
} 
sozinho. Portanto, essa atual reciclagem da imagem pública do cantor teve o apoio institucional do escritório Som Livre. Em 2007, o cenário foi o oposto desse. O grande público se identificava com a penosa trajetória vivida pelos irmãos rumo ao sucesso. Nessa época, ao participar de algum programa televisivo, Victor se emocionava ou até chorava ao falar sobre a cumplicidade na vida e na arte ao lado do irmão. Um desses episódios aconteceu em 2011, quando foram convidados para relembrar as histórias difíceis do início da carreira da dupla, em um quadro televisivo do programa Domingão do Faustão ${ }^{164}$. Victor se lembrou de uma ocasião em que os dois estavam no centro de São Paulo (eles moravam em Osasco) para conhecer alguns lugares onde pudessem tocar. Em uma manhã, com R\$13,00, Leo quis comer por ali. "Pegamos um prato feito, e sobrou apenas R\$ 3,00. Mas como existia o CPMF, não tínhamos mais dinheiro para o ônibus da volta, e não conhecíamos ninguém a quem pudéssemos pedir ajuda", disse Victor. Leo resolveu entrar em um boteco e viu uma máquina de caça-níquel, que custava $\mathrm{R} \$ 0,25$. "Na hora em que eu coloquei a moeda, a máquina começou a apitar e saíram 80 moedas de $\mathrm{R} \$ 0,25$. Coloquei tudo dentro da minha camisa e conseguimos o dinheiro da passagem de volta na sorte". E assim, "causos" como esses foram os responsáveis pelo firmamento de um pacto afetivo entre os estratos médios-populares com a dupla sertaneja.

Leonardo e Victor Chaves não nasceram em berço banhado de ouro como Sorocaba. Fernando Fakri de Assis foi cercado desde tenra idade pela atuação bem-sucedida dos pais e dos avós no agronegócio do interior paulista. Na Zona da Mata mineira, a família de classemédia tinha pequenas propriedades herdadas dos avôs imigrantes dinamarqueses e italianos. Os irmãos tiveram uma infância e adolescência modesta. O pai foi funcionário público do Banco do Brasil e a mãe dona-de-casa. Victor e Leo completaram apenas o ensino médio, então, decidiram deixar os estudos de lado para se profissionalizarem no ramo musical. Por certo, foram ajudados financeiramente pela família enquanto o sucesso não bateu às portas. Não há dúvidas de que, ao examinar a fundo a dimensão da história social dos quatro músicos sertanejos, foi notável a assimetria social entre eles. É claro que essas trajetórias heterogêneas foram condicionadas pela origem social particular de cada um deles. No entanto, nota-se que essas mesmas diferenças sociais não foram capazes de determinar um destino social tão equidistante entre Leonardo Chaves e Fernando Fakri de Assis (Sorocaba): ambos lograram êxito na dupla atuação empresarial e artística. Isso só foi possível graças às inúmeras

\footnotetext{
${ }^{164}$ Gshow/Globo: Victor e Leo relembraram histórias do início da carreira, 23/10/2011.
} 
estratégias de reconversão social ${ }^{165}$, acumulação ${ }^{166}$ e retradução de capitais ${ }^{167}$ (econômico, social, cultural e simbólico) que os dois músicos rivais se valeram. Sorocaba herdou grande volume de patrimônio financeiro, porém optou por reinvesti-lo em outro conjunto de bens, decisivo no show business sertanejo: o capital tecnológico/artístico. Leo fez o caminho inverso: nesse ínterim de vinte quatro anos (1992-2016) de atuação profissional na música, reuniu amplo conhecimento artístico que pôde ser convertido posteriormente em títulos econômicos para investimentos bem lucrativos: negócios no ramo da pecuária ${ }^{168}$, setor imobiliário $^{169}$, empresa de loteamento ${ }^{170}$, companhia de imóveis ${ }^{171}$, o estúdio musical BR Chaves Studio ${ }^{172}$, a produtora R. Chaves ${ }^{173}$, o escritório administrativo Vida Boa ${ }^{174}$ e as Editoras Chaves ${ }^{175}$.

Leo concilia ainda dois outros papeis: o artista-atleta e o pai-modelo.

\begin{abstract}
165 "As reconversões traduzem-se por outros tantos deslocamentos em um espaço social que nada tem de comum com o espaço, a um só tempo, irreal e ingenuamente realista dos estudos de 'mobilidade social'. A mesma ingenuidade positiva que leva a descrever como mobilidade ascendente os efeitos das transformações morfológicas das diferentes classes ou frações de classe conduz a ignorar a reprodução da estrutura social pode, em determinadas condições exigir uma hereditariedade profissional, bastante baixa: esse é o caso sempre que, para manter sua posição na estrutura social e as propriedades ordinais que lhe são associadas, os agentes são obrigados a proceder a uma translação acompanhada por uma mudança de condição social" (BOURDIEU, Pierre. A Distinção, 2007, p.122).
\end{abstract}

${ }^{166}$ No artigo, Pierre Bourdieu: A Teoria na Prática, Hermano Roberto Thiry-Cherques esclarece: "Bourdieu deriva o conceito de 'capital' da noção econômica, em que o capital se acumula por operações de investimento, se transmite por herança e se reproduz de acordo com a habilidade do seu detentor em investir. A acumulação das diversas formas de capital se dá por investimento, extração de mais-valia etc. O conceito de capital etimologicamente o mesmo que o cabedal ou conjunto de bens — é complexo. Além do econômico, que compreende a riqueza material, o dinheiro, as ações etc.(bens, patrimônios, trabalho), Bourdieu considera: o capital cultural, capital social e capital simbólico" (2006, p.38).

167 "As formas de capital são conversíveis umas nas outras, por exemplo, o capital econômico pode ser convertido em capital simbólico e vice-versa” (Idem, Questões da Sociologia, 2003, p.114).

${ }^{168}$ Nas fazendas, Leo faz criação de cavalo, engordas de bois e seleção de gado senepol.

169 Águas do Paraíso, um loteamento com 12 chácaras de alto padrão em uma península próxima à Uberlândia.

${ }^{170}$ A nova empresa de loteamento (ainda sem nome) junto de outros sócios.

${ }^{171}$ Libra, sua empresa de imóveis.

${ }^{172}$ Onde a dupla e outros cantores agenciados por Leo Chaves gravam os seus CD’s.

${ }^{173}$ Produtora que reúne elenco de novos artistas.

${ }^{174}$ Empresa particular que administra a carreira da dupla (sede em Uberlândia).

${ }^{175}$ A empresa surgiu quando Leonardo Chaves começou a escrever músicas: “Quem sempre escrevia as músicas antes era o meu irmão Victor. Há uns quatro anos, despertou em mim a vontade de colocar alguns sentimentos para fora. Desde então, venho compondo e escrevendo cada vez mais". Fonte: Revista Forbes, agosto de 2015. 
Em redes sociais, como Instagram e Facebook, o cantor compartilha com seus seguidores, quase que diariamente, fotos da sua rotina atlética, tanto na sala de musculação quanto na natação. É certo que o olhar atento do público sempre está voltado para o seu belo porte físico: o artista tem 1,94 de altura, a pele bronzeada e os músculos bem-definidos. Nos palcos, defende o lema de que: “o esporte é educação para as crianças do nosso país"176 ${ }^{\text {. Na }}$ entrevista dada à revista Forbes, o sertanejo confessou que desde a infância o esporte é uma paixão e hoje é uma prática essencial à sua vida: “É o esporte que me ajuda na agenda atribulada. Já joguei futebol, handebol, vôlei e fiz competição com cavalo. Nos últimos três anos, eu descobri o triatlo, mas ainda não consegui participar de competições devido à falta de tempo. Antes dos shows, faço uma hora e meia de aeróbica para gastar energia, pois sou bastante hiperativo. Também corro, pedalo e faço artes marciais, tudo para dar energia e condicionamento" ${ }^{" 177}$. Outro personagem bem-desempenhado é o pai-modelo - aquele que consegue aliar os projetos profissionais e artísticos sem deixar de lado a função paternalista: "É difícil conciliar tudo [casamento e ser pai de dois filhos e de um terceiro a caminho], tenho muitos compromissos e gostaria de ser mais presente. Mas a minha esposa, mesmo no sexto mês de gestação, consegue lidar bem com a rotina" ${ }^{\text {"178 }}$. Leonardo Chaves consegue desempenhar inúmeros papeis sociais em um único personagem, e ainda assim, não se transformar em uma figura contraditória. Essa institucionalização de um carisma "curinga" foi a mesma receita de sucesso que a apresentadora de TV Hebe Camargo usou com seu público na década de 1970 . Sergio Miceli ${ }^{179}$, ao analisá-la em seu programa de auditório, concluiu que a apresentadora assumia com naturalidade os diferentes papeis sociais da classe-média: a esposa, mulher, mãe, madrinha etc. Assim, Hebe Camargo reproduzia para o seu público os valores culturais e as normas comportamentais da própria classe-média brasileira. Em suma, quatro décadas depois, são os músicos sertanejos empreendedores, como Leonardo Chaves e Fernando Fakri de Assis "Sorocaba", os responsáveis por reproduzir esses padrões culturais junto ao público. Com certeza, nenhum dos dois pertence a esse mesmo estrato social, ao contrário, os músicos são representantes das frações dominantes do polo econômico. No entanto, dentro e fora dos palcos, sabem interpretar e reproduzir as crenças materiais e simbólicas dos seus consumidores.

\footnotetext{
${ }^{176}$ Declaração de Leonardo Chaves no primeiro dia de gravação do DVD Ao Vivo Irmãos, 28 de janeiro de 2015.

${ }^{177}$ Revista Forbes: Leo Chaves, o cantor sertanejo dos negócios, 30/08/2015.

${ }^{178}$ Idem, agosto de 2015.

${ }^{179}$ MICELI, Sergio. A Noite da Madrinha. São Paulo: Perspectiva, 1972.
} 
No último trecho da reportagem, Leonardo Chaves faz um "aviso" no mínimo ambíguo: "No futuro, eu quero ser mais lembrado como empresário do que como músico um desafio a mais para quem começou cantando na noite paulistana, em 2001, e hoje comemora a venda de 1,8 milhões de CD's no Brasil e no exterior”. O público leitor de uma revista como a Forbes não é o mesmo daquele encontrado nos shows do cantor e, em vista disso, que tal declaração pôde ser feita sem inibição alguma. Talvez, seja por esse motivo que Leo tenha omitido por tantos anos seu favoritismo pelo desempenho empresarial. Uma vez que isso fosse posto, seria feito à custa de prováveis prejuízos financeiros na promoção da carreira artística. O sertanejo sabia que o prestígio comercial da dupla "Victor e Leo" era o seu cheque-caução de entrada no mundo dos negócios. Mas, esse novo arquétipo empreendedor trouxe outros questionamentos. Um deles é se ainda existe alguma validade no discurso sobre a valorização da tradição na música sertaneja. Em 2014, Leo garantiu ao jornalista José Hamilton Ribeiro que “definitivamente, ele não faz uma música pensando só no intuito comercial". Nos palcos, aquelas mensagens ditas ao público de que a música: “Transforma a vida das pessoas para melhor. A única forma de retribuir todo esse carinho é se dedicar a ser um músico melhor, e a cada dia que passa fazer uma música melhor para vocês, com mais qualidade, com mais sentimento e verdade musical. É isso que a gente quer: subir no palco e abrir sorrisos. Não tem como retribuir isso! O único jeito é se comprometer em fazer o melhor no palco, no estúdio para que vocês possam se emocionar de com a nossa música e nossa arte" ${ }^{\$ 180}$, na prática, parecem contradizer sua vontade de ser lembrado no futuro mais como empresário do que como músico. Outra questão: Victor não participa dos investimentos financeiros do irmão. Se no futuro Leonardo fosse lembrado somente como empresário, qual teria sido o sentido do legado deixado pela dupla na história social da música sertaneja? Se um dia os dois já compartilharam as mesmas motivações e chegaram de mãos dadas às portas do sucesso, por que agora Leonardo ambiciona conservar a figura de um empresário em vez de um artista-ícone? A resposta para essa pergunta-chave está na relação afetiva-profissional existente com o irmão. Victor pôde desenvolver suas habilidades musicais, ainda na primeira infância, graças às investidas sucessivas dos pais dentro do ambiente familiar. No presente, Victor reproduz a crença de uma ideologia do dom ${ }^{181}$ inato pela arte, mas que é na prática, um produto histórico de sua socialização precoce com a

\footnotetext{
${ }^{180}$ Leo comemorou seu aniversário no show do Espaço das Américas, 03 de outubro de 2014.

181 “A ideologia da percepção ou da interpretação criadora, constituída como uma representação carismática que tende a atribuir à vocação artística seja pela produção criadora ou pela aptidão de entendê-la e conhecê-la, um “mistério" consagrado a alguns eleitos” (Idem, A Economia das Trocas Simbólicas, 2001, p.280).
} 
música: "Eu criei minha própria maneira de tocar instrumento. A primeira composição que escrevi a chamei de invenção, pois não conhecia o verbo compor, muito menos a função de um compositor. Em 1993, em Abre Campo, disse: vou inventar uma música. Chama-se Flor do Campo, que gravamos no álbum Boa Sorte pra Você (2010)",182.

$\mathrm{Na}$ trajetória artística ao lado do irmão, Victor foi o responsável pelo protagonismo musical do dueto, atuando como compositor, arranjador, produtor, cantor (primeira e segunda voz) e instrumentista. Até a ida para Som Livre, o papel de Leo estava restrito apenas ao de vocalista. Mas, o novo formato comercial oferecido pela gravadora trouxe uma série de conflitos de interesses entre os dois. No começo, Victor deu aval para que o irmão pudesse ter maior notoriedade midiática e também apoiou o seu projeto de atuação como compositor. Além disso, Leo passou a participar efetivamente de todas as etapas de elaboração dos CD's e DVD's, convidando inclusive artistas de outros gêneros para parceria musical. Em setembro de 2013, o escritório Som Livre sugeriu a gravação de um videoclipe para a canção Na Linha do Tempo - o primeiro na história da dupla sertaneja. O convite foi aceito cordialmente e os dois apareceram juntos em um luau. Em março de 2014, a gravadora pediu um bis e, nos bastidores, Victor não ficou muito empolgado. Dessa vez, para a faixa O Tempo Não Apaga, eles surgiriam separados em cena e Leo teria que interpretar o papel do "moreno, alto, bonito e sensual" pelas praias cariocas ${ }^{183}$. Para o portal $I G$ Sertanejo ${ }^{184}$, os músicos declararam: “A gente não queria aparecer fazendo posezinha". A jornalista Marília Neves completou: "Eles podem não ter aparecido fazendo pose de cantor, mas Leo mostrou outra faceta em vídeo fazendo a tal 'posezinha'. Desta vez, como ator" ${ }^{185}$. Não poupando modéstia, Leo perguntou: "Você acha? Acho que fui dirigido ali pelo Renato Cabral, ele falava 'faz uma cara assim, agora franze a testa'. Achei que ficou bom até depois. Não estava acostumado a fazer isso não. Enfim, esse lance de não ter participado como cantor foi diferencial. Foi muito bom isso ấ" ${ }^{\prime 186}$. O ofício foi tão bem-recebido que Leo o carregou até aos palcos em 2014. Em pouco tempo, o desapontamento de Victor já estava visível a olhos nus. Talvez, o momento derradeiro de abandonar os palcos e ficar nos bastidores estava próximo - uma aposentadoria tão prematura quanto foi sua precocidade com a música. Entretanto, mesmo que a parceria

\footnotetext{
${ }^{182}$ Victor Chaves. Fonte: do autor (2015).

183 "Desde o início, quando a gente começou a conversar sobre o roteiro da música, falei de cara que eu não queria que a gente fosse cantor no clipe", disse Leo à jornalista Marília Neves. Fonte: IG Sertanejo: Victor e Leo falam sobre o novo clipe: "A gente não queria aparecer fazendo posezinha", 30 de março de 2014.

${ }^{184}$ Fonte: IG Sertanejo, 30 de março de 2014.

${ }^{185}$ Idem, 30 de março de 2014.

${ }^{186}$ Idem, 30 de março de 2014.
} 
profissional andasse em desacordo, Leo poderia chamá-lo de volta, não como músicoparceiro, mas como irmão-parceiro.

Em junho de 2015, Victor anunciou ao programa Fantástico que pretendia interromper a carreira ao lado do irmão em algum momento: "Uma hora ou outra a gente vai ter que dar um tempo, tempo para nós, para a gente descansar, para a mente absorver tudo o que foi vivido. Em algum momento vai acontecer. Não sei quando, se é agora ou se é depois". Leonardo não reagiu bem e desaprovou a declaração do irmão. O cantor disse que para ele, essa atitude de Victor seria muito negativa: “A separação, para mim, é sinônimo de derrota. Então, por isso mesmo que eu sequer cogito essa pausa nem em longo prazo"187. Esse prenúncio feito por Victor Chaves sobre o fim da dupla traduz o contexto fonográfico dos últimos dez anos no Brasil. Em 2005, o estabelecimento do movimento universitário na música sertaneja foi muito significativo para a renovação e o fortalecimento do gênero. Os sertanejos universitários não se deixaram abater pela crise que acometia o mercado da música. César Menotti e Fabiano e João Bosco e Vinícius preconizaram o formato acústico ao vivo, que, até agora, é a fórmula mágica do sucesso de faturamento do gênero. A parafernália de instrumentos eletrificados do sertanejo romântico foi substituída pelo violão em cordas de aço e pelo acordeom. As narrativas melodramáticas foram trocadas pelas temáticas festivas dos jovens urbanos. Por volta de 2007, Victor e Leo já eram experientes músicos de estrada ${ }^{188}$, quando se esbarraram com o sucesso comercial promovido pelo movimento universitário. Nesse cenário competitivo, mas também pouco exigente, não demorou muito tempo para que os dois se destacassem de seus concorrentes. Na bagagem, os mineiros trouxeram a receita para o estrelato: beleza física, repertório próprio, qualidade instrumental/vocal, presença de palco, boa oratória e o formato-padrão do dueto formado por irmãos. Contudo, uma fórmula em particular singularizaria o sucesso da dupla: Victor trazia em suas composições os valores tradicionais da música sertaneja - legado pouco reverenciado entre os músicos universitários. Então, Victor e Leo saíram em defesa do culto à autenticidade da música sertaneja e receberam o apoio irrestrito de Almir Sater e Renato Teixeira. De 2007 a 2013, os músicos deram bons lucros ao escritório da gravadora Sony-BMG, em especial, pelos rendimentos na vendagem de CD's e DVD's. Nesse período, a dupla conquistou prestígio e se firmou no cenário musical brasileiro. Victor estava satisfeito: produzia um álbum inédito por ano e tinha tempo para se dedicar à composição. Porém, os projetos individuais do irmão eram

\footnotetext{
${ }^{187}$ Portal R7: Victor assume que dupla com Leo pode "dar um tempo".

${ }^{188}$ Iniciaram a carreira musical em 1992, na cidade de Abre Campo (MG).
} 
audaciosos. A mudança para Som Livre (2013) pode ter sido consensual, porém beneficiou bem mais os propósitos de Leo do que o bem-estar de Victor. O compositor até que se esforçou para atender as expectativas do novo formato comercial. No entanto, desde 2014, o desgaste pessoal e profissional chegaria até aos olhos do público. Victor não escondia seu descontentamento com o irmão nem fora dos bastidores. Os bate-bocas e mal-entendidos eram resolvidos até dentro do palco ${ }^{189}$. Pouco a pouco, o escritório Som Livre foi transformando Leonardo em um personagem de novela global. Agora, a distância que o separa de Sorocaba é apenas institucional, pois o protótipo do sertanejo empreendedor é o mesmo. A rivalidade entre Victor e Leo e Fernando e Sorocaba não mudou, apenas se institucionalizou. Todavia, se Leo é um mero funcionário do Grupo Globo, Sorocaba é o dono da FS Produções Artísticas, empresa que inclusive está pleiteando as mesmas fatias de mercado que as instituições ligadas a Globo. Mas, esse é o tema do próximo capítulo.

O vulto artístico de Victor Chaves está registrado na história social recente da música sertaneja comercial. O compositor é um personagem quase inexistente na atualidade do gênero. Ele foi o responsável por trazer à tona os valores da tradição caipira/sertaneja, sem abrir mão da originalidade do seu contexto. No atual mercado fonográfico, não há mais espaço para outros "Victors". São bem-vindos apenas rentáveis "Sorocabas". Seja como for, ele ainda é fundamental para os interesses artísticos e comerciais do irmão. Em julho de 2015, um mês depois do anúncio de pausa feito por Victor, o cantor fez uma súplica pública: "Respeito a ideia do meu irmão e entendo porque a carreira tem uma agenda complicada de cumprir. São muitas responsabilidades e isso faz com que o estresse e o cansaço aumentem. Fui contra [a pausa da dupla] porque não consigo ficar sem os palcos, sem trabalhar. Se eu ficar três meses sem o palco, adoeço. É meu combustível. Preciso disso para viver. Mas respeito a opinião dele" ${ }^{\prime 190}$. Faz dois anos que o escritório Som Livre vem se preparando para um possível desligamento de Victor com o irmão. Tanto é que a gravadora vem dissociando vagarosamente a figura artística de Leonardo Chaves com o nome da dupla "Victor e Leo". No entanto, esse intervalo profissional sugerido pelo compositor não é tão promissor quanto

\footnotetext{
${ }^{189}$ Durante a gravação do álbum Irmãos, a dupla debateu no palco alguns detalhes do DVD, mostrando que, mesmo sendo irmãos, existem algumas divergências profissionais: "Quando você trafega em um meio no qual a vaidade, o ego e o assédio das pessoas estão presentes, essa coisa de ser irmão e sócio fica delicada. Mas o tempo e o nosso amadurecimento se encarregam de arrumar isso. Essas coisas que aconteceram no DVD [Irmãos] são normais entre irmãos. Somos pessoas comuns, irmãos normais", entrevista de Leo à jornalista Marília Neves. Fonte: Portal Ego/Globo: Leo Chaves sobre pausa da dupla com o irmão: "Sem o palco, adoeço", 05/julho/2015.

${ }^{190}$ Portal Ego/Globo, 05/julho/2015.
} 
se parece. Leo sabe que tal ruptura poderia afetá-lo na vida e na arte. No mercado econômico, a perda do selo de qualidade que o nome da dupla lhe oferece poderia desvalorizar os investimentos financeiros nos setores pecuários e imobiliários. $\mathrm{Na}$ atividade musical, esse mesmo cenário seria capaz de atingi-lo também. O público devotado e fiel à dupla estranharia ou até rejeitaria acompanhar o percurso solo de Leonardo. E se o carisma atribuído aos dois irmãos não fosse transferido somente a um deles? O cantor teme todos essas hipóteses e, por isso, tenta evitá-las ou retardá-las ao máximo, despistando até mesmo os profissionais da imprensa. Em entrevista dada à jornalista Marília Neves, Leo quis atenuar a polêmica de uma crise profissional ao lado de Victor, sugerindo à repórter que as diferenças entre os irmãos não são provenientes da profissão. Segundo Leo, antes mesmo da carreira musical, a relação entre os dois era bastante conturbada, pois ele sempre foi mais agitado do que Victor ${ }^{191}$. O sertanejo prossegue: "Eu era aquele tipo de adolescente que gostava de movimento, de clube, de todos os tipos de esporte. Mas havia momentos em que nós estávamos juntos, pescando, indo para a fazenda. Antes mesmo de formar a dupla, nós cantávamos juntos. Éramos diferentes como adolescentes, mas havia certos momentos em que estávamos juntos também”192. Na prática, tal crise não aconteceu por uma diferença comportamental entre os irmãos, mas pela não aceitação de Victor das imposições comerciais da gravadora que, a propósito, foram recebidas de braços abertos por Leonardo. O cantor tentou ainda uma segunda jogada, dizendo nas entrelinhas que a atitude de Victor seria egoísta ${ }^{193}$ se comparada à sua própria renúncia familiar frente à responsabilidade artística: “O maior problema na minha vida é administrar minha ausência em casa, com meus filhos. Estou fora em momentos cruciais. Já não estive em aniversário dos dois [Antônio e Matheus]. O maior problema que tenho é isso: eles terem mais minha ausência do que a presença"194.

A trama afetiva surtiu efeito sobre Victor e ele voltou atrás: confirmou a agenda de shows para 2016. No mesmo ano, os dois participaram ao lado de Ivete Sangalo e Carlinhos Brown como jurados do programa The Voice Kids ${ }^{195}$. No dia 3 de janeiro, Victor e Leo

\footnotetext{
${ }^{191}$ Portal Ego/Globo, 05/julho/2015.

192 Portal Ego/Globo, 05/julho/2015.

${ }^{193} \mathrm{Na}$ época, o compositor não estava casado, apenas namorava a empresária Poliana Bagatini. No dia 22 de setembro de 2015, o "cantor Victor Chaves anuncia que será papai”. Fonte: Portal Ego/Globo: Cantor Victor anuncia que será papai, 22/09/2015.

${ }^{194}$ Revista Forbes, 05/07/2015.

${ }^{195}$ Um talent show brasileiro exibido em uma versão infantil (participantes de 9 a 15 anos), aos domingos, pela Rede Globo.
} 
estrearam de forma inusitada: apareceram sentados em uma cadeira conjunta e teriam que decidir juntos se apertariam o botão "Eu Quero Você" para os candidatos-mirins aprovados: “A cadeira só vai girar quando os dois entrarem em concordância. Nós estamos nos dando bem com isto. Na hora a gente se resolve. E ouvir esses talentos vai ser bom demais"196. O convite oferecido aos músicos para participarem de tal programa televisivo indica o quão valoroso é o nome da dupla na atualidade. Na música sertaneja, são raros os exemplos de artistas que mantêm um público dessa faixa etária. Ademais, Victor e Leo são benquistos por ouvintes de outros estilos musicais que sequer apreciam o gênero sertanejo, tudo isso graças à qualidade vocal, instrumental e composicional reunida pelos dois ao longo da trajetória profissional. No presente, Victor e Leo são artistas-ícones dentro do campo da música popular brasileira e bem-vistos aos olhos da crítica musical, dos meios de comunicação de massa e do grande público. Trocando em miúdos: a marca "Victor e Leo" é o grande patrimônio material e simbólico da dupla Victor e Leo. Isso explica porque Leonardo tem resistido tanto sobre a pausa sugerida pelo irmão. Se Victor recuar para os bastidores, o cantor não apenas "adoeceria" sem os palcos, mas também poderia perdê-lo de vez, frente à concorrência feroz de artistas como Sorocaba. Talvez seja por isso que no futuro ele queira ser lembrado mais como empresário do que como músico. Se o compositor deixá-lo, restará a ele, em pouco tempo, somente o protagonismo da atuação empresarial. Leo enxerga isso e, portanto, tem feito o impossível do possível para mantê-lo ao seu lado. Em última instância, se o apelo para evitar o fim da dupla não surtir efeito sobre o músico, o cantor pode trazê-lo de volta ao "cargo" no papel de irmão. Esses laços de codependência tanto afetivos quanto profissionais conduziram toda a experiência social da dupla - algo inexistente entre Fernando Zorzanello e Sorocaba. No final das contas, o êxito na atividade artística dos irmãos foi o produto de um longo investimento familiar. Da infância até a fase adulta, Victor e Leo estabeleceram uma relação de interdependência afetiva ${ }^{197}$ que foi transferida para a música. Essas estruturas psicossociais incorporadas no ambiente familiar, hoje são as responsáveis pelos sentimentos de culpa e compromisso que despertam tanta hesitação na decisão de Victor sobre o fim da parceria musical com Leo. Por enquanto, o compositor sabe atender com resignação aos interesses do seu grupo familiar e, sobretudo, à cobiça individualista do irmão.

\footnotetext{
${ }^{196}$ Gshow/Globo: Victor e Leo explicam novidade da cadeira dupla no The Voice Kids, 30/12/2015.

197 O peso das estruturas familiares foi bem exemplificado por Norbert Elias em seu estudo de caso sobre Mozart. Desde tenra idade, a relação de dependência afetiva do filho com o pai foi o condicionante fundamental para o desenvolvimento precoce das habilidades musicais de Mozart. Mais tarde, a influência paterna seria novamente a responsável pelo êxito do ofício do filho dentro da sociedade de corte vienense.
} 

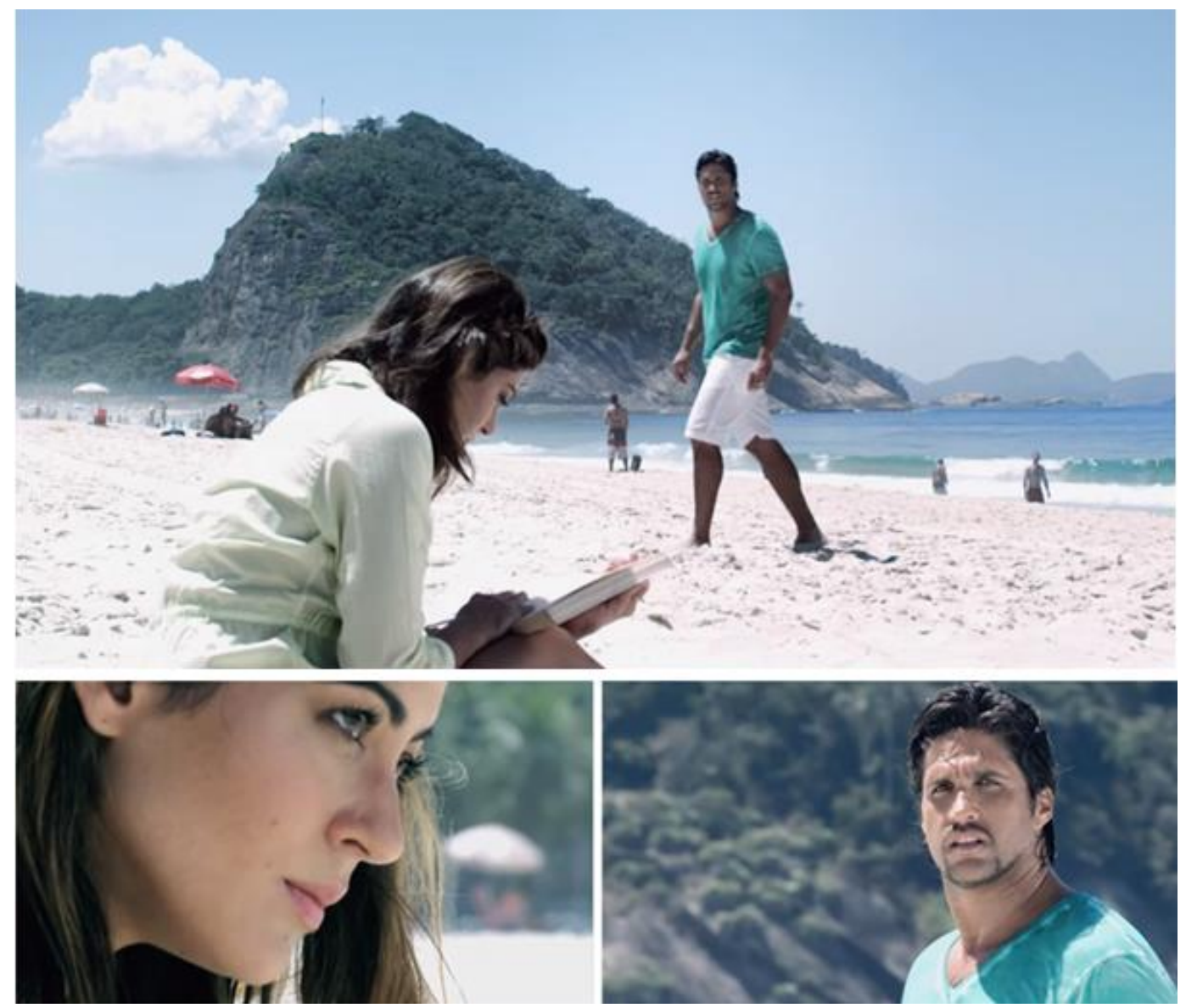

O videoclipe de O Tempo Não Apaga, 2014 (Som Livre). Leonardo Chaves contracena com a atriz global Carol Castro. O mineiro encena o papel do latin lover sertanejo que caminha pelas praias cariocas, exibindo seu corpo atlético e bronzeado no estilo macho-alfa. Nas imagens, o músico tem um excelente desempenho frente às câmeras - Leo fita intensamente os olhos da bela mulher, com precisão quase cinematográfica. Não há como discordar da jornalista Marília Neves - o cantor leva jeito para ser ator também. Foto: divulgação.

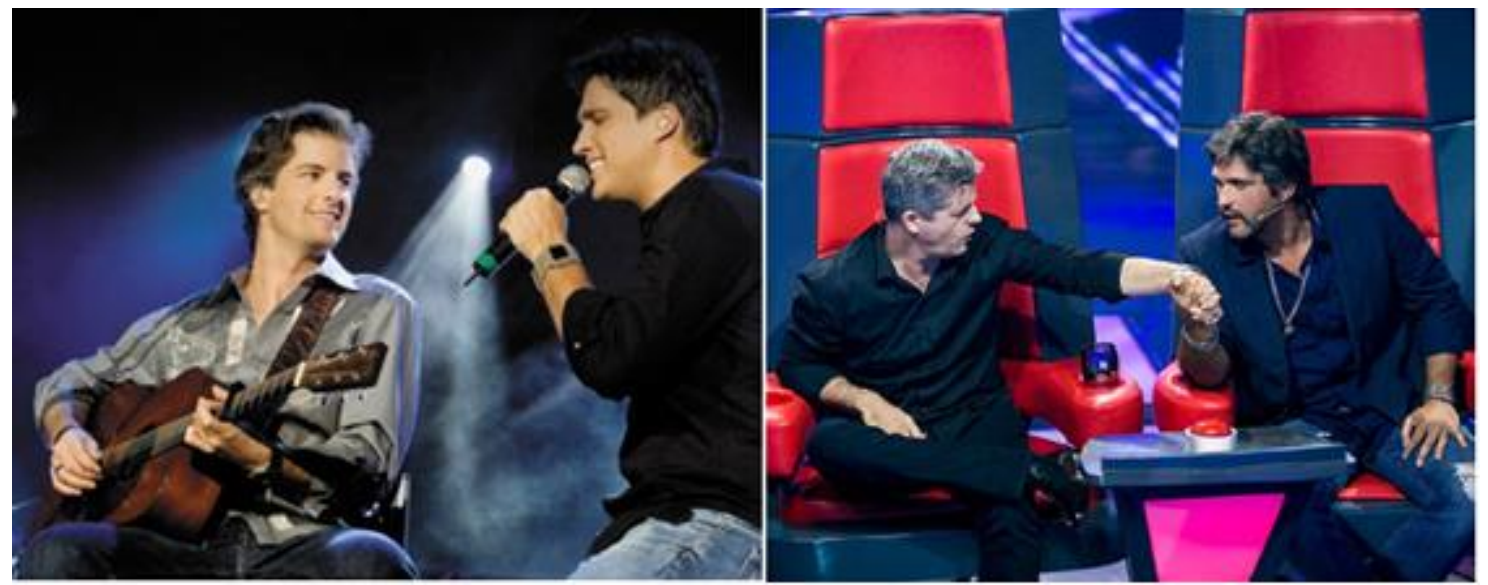

À esquerda, foto da gravação do primeiro DVD Ao Vivo em Uberlândia (2007). Victor transborda felicidade pela conquista junto ao irmão. Nota-se no olhar do compositor a admiração por Leo. Os dois compartilhavam, sem esforço algum, uma afinidade corporal e facial harmônica. Foto: divulgação. À direita, Victor e Leo como jurados do programa The Voice Kids, 2016 (Rede Globo). Quase dez anos depois, o equilíbrio entre os dois é garantido pela cadeira conjunta. No passado, a conexão entre eles era imediata e natural. Hoje é necessário um artefato cênico para efetivar tal associação. Victor é retratado com roupas sociais, as pernas cruzadas e de mãos dadas com o irmão. Leonardo fixa-se seriamente nos olhos do compositor e aparece mais a vontade - de pernas abertas e figurino despojado. Foto: Isabella Pinheiro/Gshow. 


\section{A "dupla" identidade de Fernando/Sorocaba: o artista caubói e o empresário milionário da música sertaneja}

Sou apaixonado por cavalos e pela natureza. Fui criado no haras do meu avô, e todo aquele clima de campo, em meios aos cavalos, tudo isso me aproximou muito da música sertaneja e do country norteamericano, isso é muito visível nas minhas canções.

Algumas das nossas canções receberam arranjos mais modernos e com bases de guitarra, bateria, banjo, mandolin, steel guitar e até elementos eletrônicos. Eu busco inovar sempre, os nossos fãs merecem. O público vai ao show querendo ver música e entretenimento $^{198}$.

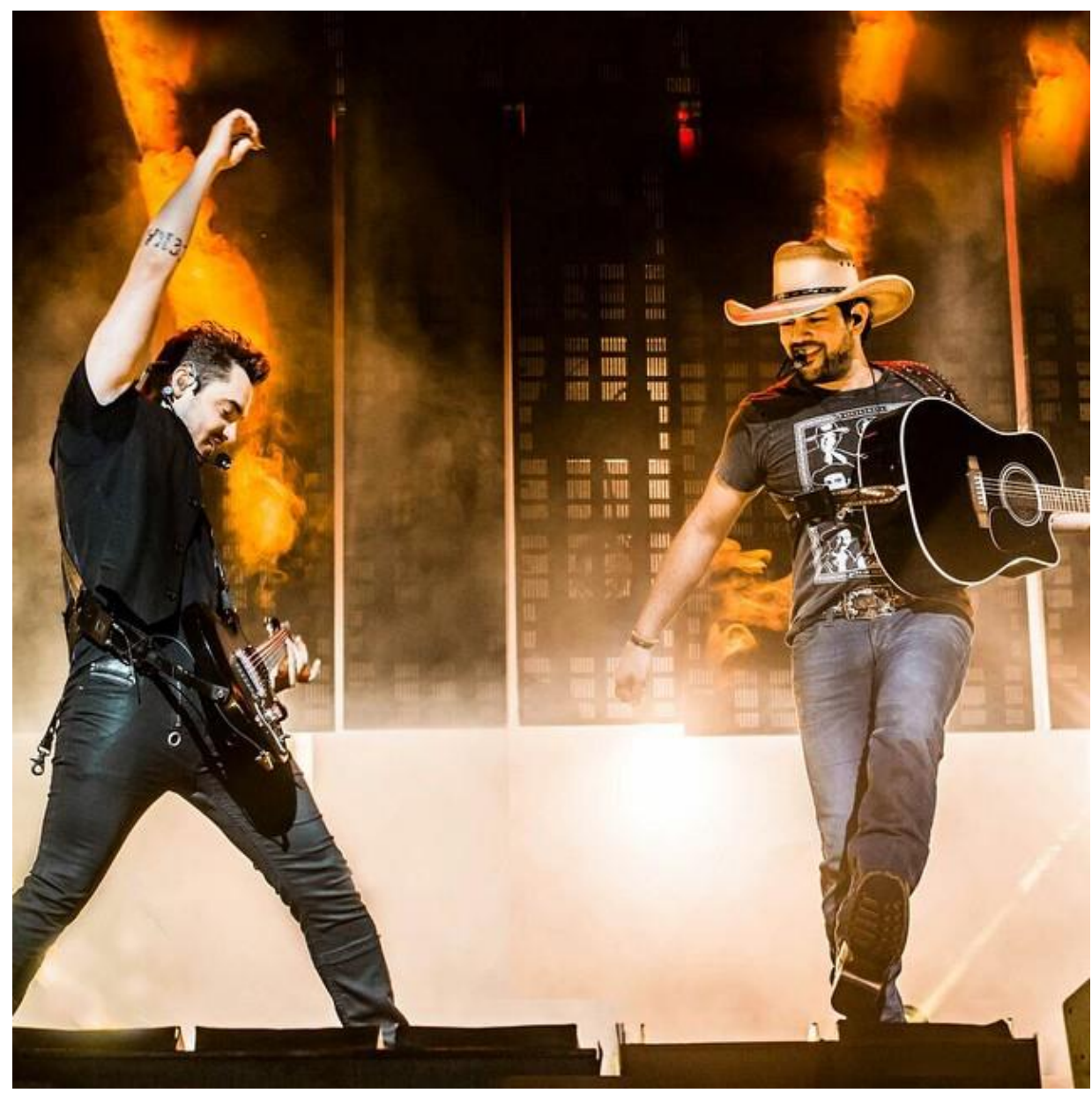

Apresentação no Citibank Hall no dia 27 de setembro de 2014. Fernando Zorzanello com a guitarra à esquerda e Fernando/Sorocaba apoiado no violão à direita. Foto: divulgação.

\footnotetext{
${ }^{198}$ Fernando Fakri de Assis "Sorocaba". Fonte: do autor (2015).
} 
Aos 20 anos, o paulistano Fernando Fakri de Assis (criado na cidade de Sorocaba SP) mudou-se para Londrina para cursar agronomia na Universidade Estadual de Londrina (UEL). Nesse ínterim, não primou muito pelos estudos no ambiente acadêmico, pois sua atenção estava voltada à música. No segundo ano de faculdade, já pagava suas contas graças às apresentações nos bares e festas dos circuitos universitários da cidade. Em outubro de 2006, ele registrou em cartório a marca "Fernando e Sorocaba", mesmo antes da parceria com Fernando Zorzanello. Entre 2005, 2006 e 2007, Humberto Santiago foi o primeiro "Fernando" da dupla. Em setembro de 2006, ao lado de "Fernando", Sorocaba lançou seu primeiro CD e DVD, Ao Vivo em Londrina. O dueto não deu certo. Em 2014, Humberto Santiago chegou a pleitear na justiça os direitos autorais da dupla ${ }^{199}$.

O músico conheceu seu segundo "Fernando" apenas em 2007. No ano seguinte, eles lançaram pela gravadora Universal o CD e DVD Bala de Prata (2008) - o primeiro na atual formação. O álbum foi gravado ao vivo às margens do Rio Bandeirantes do Norte, na cidade de Santa Fé, Paraná. O acústico reuniu um público de dez mil pessoas e o álbum lhes rendeu disco de ouro pela venda de mais de 50 mil cópias. Atualmente, Sorocaba não divide os lucros dos shows com Fernando Zorzanello, visto que o nome da dupla já tinha sido patenteado antes mesmo da formação atual do duo sertanejo. Além disso, o músico tem direito às participações nos lucros de Luan Santana. Sorocaba foi o responsável pelo sucesso do astro teen da música sertaneja - aliás, até a música Meteoro da Paixão (2009), que empurrou Luan Santana ao estrelato nacional, foi escrita pelo compositor-empresário ${ }^{200}$.

Fernando "Sorocaba" é dono do escritório FS Produções Artísticas (com sede no bairro de Moema, São Paulo) que agencia novos artistas sertanejos e de outros gêneros como Lucas Lucco; Laubet; Thaeme e Thiago; Marcos e Belutti; o grupo de pagode, Inimigos da

\footnotetext{
${ }^{199}$ Movimento Country: Primeiro "Fernando" processa Sorocaba por uso indevido do nome, 21/08/2014.

200 "O Luan tem o tipo dele, a forma de cantar dele, tinha um público muito bem definido. Então, aquela música se encaixava perfeitamente nele. Se alguém gravasse e não tivesse esse perfil, provavelmente, não chegaria perto do sucesso que ele conseguiu. Sobre o fato de ele ter se tornado maior que a dupla na época, longe de ter sido um problema. Como eu te disse, eu sempre pensei no segmento 'música sertaneja' como um todo. O Luan Santana agregou muito, trouxe um público muito grande ao sertanejo, ajudou a expandir o mercado. Quantos jovens não foram apresentados ao sertanejo através do Luan Santana, depois conheceram Fernando e Sorocaba, Jorge e Mateus, Victor e Leo, até Chitãozinho e Xororó e até Tião Carreiro e Pardinho? Por isso que a palavra 'concorrência', às vezes, pode passar uma impressão errada. É claro que você quer ser o maior, mas o sucesso alheio, muitas vezes, é muito positivo para os outros artistas". Entrevista de Sorocaba a André Piunti. Fonte: Universo Sertanejo, 13 de maio de 2013.
} 
HP e a cantora Tânia Mara ${ }^{201}$. O cantor ainda é sócio da casa noturna sertaneja Wood's (Vila Olímpia, São Paulo). O artista caubói soube também construir sua imagem pública: ele aparece sempre bem-maquiado, usando chapéu, cintos, fivelas e botas em couro de cobra - no estilo texano. Em uma década de carreira musical ${ }^{202}$, ele tem registrado mais de 100 fonogramas em seu nome. Aos 35 anos de idade, Fernando Fakri de Assis é um exemplo bemsucedido do empreendedorismo artístico no mercado musical brasileiro. Sorocaba tem uma trajetória social muito diferente da realidade de outros músicos sertanejos ${ }^{203}$. Nascido em uma família abastada do agronegócio do interior paulista, aprendeu precocemente o ofício capitalista de investimento econômico. O herdeiro aceitou o patrimônio social do seu grupo familiar, porém, optou por reinvesti-lo - não em commodities, mas na música ${ }^{204}$. Sorocaba foi socializado em meio à moderna agropecuária do universo rural brasileiro, no "clima do campo do haras do avô" e na "paixão pela natureza e pelos cavalos". A figura empreendedora despontou desde a adolescência: "Eu componho desde os 13 ou 14 anos. Comecei a cantar e tocar cedo também. O lado empresarial foi uma consequência desse envolvimento com a música" 205.

A "busca por inovação", "o público que merece música e entretenimento", "os arranjos modernos" e todas as promessas ditas por Sorocaba na epígrafe, de fato, são retraduzidas no próprio show. A “inovação" está presente no investimento tecnológico

\footnotetext{
201 "Viola meu lucro! Os artistas cujas carreiras são administradas por Sorocaba: Luan Santana, descoberto por Sorocaba, que compôs Meteoro, música que o fez estourar. O empresário detém $20 \%$ dos direitos sobre a receita do cantor; Thaeme e Thiago: é considerada a revelação do sertanejo de 2012. A FS Produções Artísticas é dona de 100\% dos direitos sobre a dupla; Marcos e Belutti: o empresário detém 30\% sobre os ganhos da dupla. Um show custa R \$ 120 mil; Inimigos da HP: fora do meio sertanejo, a banda de pagode foi para o escritório de Sorocaba para ser reformulada; Tânia Mara: a cantora, esposa do diretor de novelas da Rede Globo, Jayme Monjardim, tem a carreira administrada pela FS Produções Artísticas". Fonte: Isto é Dinheiro: O sertanejo milionário da capital, 10/10/2012.
}

\footnotetext{
202 “Com seis anos de carreira profissional, a dupla movimentou, em uma estimativa conservadora, R\$ 40 milhões em shows, somente em 2011. Metade desse dinheiro foi embolsada pelos dois. Sorocaba também é o compositor cujas músicas são mais executadas no país: com mais de R \$ 500 mil arrecadados em 2011, de acordo com o ECAD. Ele é o campeão nacional de direitos autorais, superando nomes badalados como Roberto Carlos e Caetano Veloso. Não bastasse isso, ainda se dedica à vida de empresário do ramo musical e esportivo. Com a FS Produções Artísticas, Sorocaba está construindo um negócio lucrativo: descobrir novos talentos e administrar à carreira e imagem de artistas da cena musical brasileira”. Fonte: Idem, 10/10/2012.

\begin{abstract}
203 "Ele nasceu pobre, no interior de Goiás, trabalhava na roça e dedicou anos à música sertaneja até conseguir o tão esperado sucesso. Essa seria a história de muitos cantores desse estilo de música, mas certamente não é o caso de Fernando Fakri de Assis, de 32 anos, o Sorocaba da dupla sertaneja Fernando e Sorocaba, uma das responsáveis por renovar o gênero musical no país. Criado no bairro do Ibirapuera, na capital paulistana, nascido em uma família abastada, o contato do músico com o mundo sertanejo começou ainda criança, quando passou a frequentar o haras do avô, na cidade do interior de São Paulo que inspirou seu nome artístico”. Idem, 10/10/2012.
\end{abstract} ${ }^{204}$ A revista $C Q(24 / 02 / 2012)$ trouxe um título bem ilustrativo sobre o artista: "Ele não nasceu no campo, nunca foi
pobre e nem trabalhou na roça".

${ }^{205}$ Sorocaba. Fonte: do autor (2015). 
administrado pelo artista ano a ano. Suas apresentações são transformadas em espetáculos repletos de efeitos digitais, ilusionistas e pirotécnicos, em um ambiente onde o espectador é convidado para participar da moderna balada pop sertaneja ${ }^{206}$. Um público-consumidor mais jovem, urbano e escolarizado que procura na música uma trilha-sonora para o entretenimento: "Meu segredo como compositor é ter conseguido desenvolver esse filtro popular, eu não nasci sabendo. Minhas primeiras composições eram bobinhas demais, depois passei a pirar demais e errar a mão. Levou tempo pra me ajustar e desenvolver essa espécie de controle. Os acertos vêm quando esse processo deixa de ser racional e passa a ser natural"207. Na prática, as composições musicais do empresário paulista funcionam como verdadeiras alegorias das mudanças econômicas, sociais e culturais ocorridas no Brasil nos últimos quinze anos. Sorocaba soube se ajustar as novas configurações da indústria musical brasileira - um mercado fonográfico que não pode mais depender exclusivamente da vendagem de CD's e DVD's, mas sim do investimento tecnológico no show business.

Então, vamos examinar sua trajetória social e a de seu parceiro Fernando Zorzanello. Fernando (nome artístico de Fernando Zorzanello Bonifácio) é natural de Ji-Paraná Rondônia (21 de abril de 1984) e Sorocaba (nome artístico de Fernando Fakri de Assis) é nascido em São Paulo (15 de setembro de 1980). Este último foi criado entre a capital paulistana (no bairro do Morumbi) e a rotina rural da fazenda da família em Sorocaba (SP). Na graduação, Fernando recebeu dos colegas de república o apelido de "Sorocaba" pelo forte sotaque interiorano. Seus pais são o advogado José Carlos de Assis e a administradora de empresas Renata Nogueira Fakri de Assis. Tem duas irmãs: Karina e Juliana. O primo Fábio Fakri é sócio de Sorocaba e atuou como empresário do cantor Luan Santana entre 2006 a $2013^{208}$. De uma família de classe-média alta, bem-sucedida do agronegócio do interior paulista, Sorocaba possui o título de bacharel em agronomia pela Universidade Estadual de

\footnotetext{
206 "Sorocaba faz o perfil do artista-empresário, sempre planejando cada passo na carreira, a começar pelo nome da dupla. No início, fez par com um cantor chamado Santiago, que topou mudar o nome para melhor se adequar à marca. Seis anos atrás, Santiago foi trocado pelo cantor e guitarrista Fernando Zorzanello Bonifácio. Com efeitos especiais e solos de guitarra, as apresentações de Fernando e Sorocaba estão mais para show de pop rock do que para toada sertaneja". Fonte: Revista Veja: O Brasil virou sertão, p.86, 30/01/2013.

${ }^{207}$ Portal Universo Sertanejo: Entrevista de Sorocaba ao jornalista André Piunti, 13 de maio de 2013.

208 "Nesse empreendimento, é seu sócio o parceiro Fernando, seu primo Fábio Fakri, responsável pela administração da empresa, e Fábio Elias, que faz a venda dos shows. A primeira descoberta de Sorocaba foi o cantor Luan Santana, ícone do circuito sertanejo universitário, que já vendeu mais de dois milhões de CD's e DVD's e cobra aproximadamente R\$ 300 mil por um show, um dos cachês mais caros do país. Hoje, Luan tem sua própria empresa para administrar sua carreira, mas Sorocaba ainda detém $20 \%$ dos direitos sobre suas receitas, que teriam chegado a R\$ 70 milhões nos últimos dois anos". Fonte: Idem, 10/10/2012.
} 
Londrina (UEL): "Eu terminei o colégio e passei na faculdade de agronomia. Como eu passei toda a minha infância no campo, me identifico muito com essa profissão. Foi inevitável escolher essa faculdade, e se eu não fosse músico, provavelmente teria seguido essa carreira" ${ }^{209}$. Inclusive, foi durante seus estudos universitários, que ele iniciou sua carreira musical nos bares noturnos da cidade paranaense de Londrina. No começo, a família encarava apenas como um passatempo, mas quando o filho começou a se bancar sozinho, eles perceberam que o tal hobby se tornou uma rentável profissão: "Eu comecei a tocar em bares e casas noturnas. Cantava grandes sucessos da música sertaneja e apresentava também as minhas composições, isso chamou a atenção das pessoas. Eu tocava quase todas as noites e durante o dia estudava. Era ainda mais difícil quando estava na semana de provas, porém valeu muito a pena. A minha família sempre me apoiou"210.

O avô era dono do haras Rancho das Américas, na cidade de Porto Feliz (interior do estado de São Paulo) e foi o responsável por incentivá-lo, desde cedo, o aprendizado musical. Aos onze anos, Sorocaba ganhou dele seu primeiro violão, mas o avô já o iniciara na música aos sete anos de idade: "Nunca frequentei nenhum tipo de conservatórios ou escolas musicais.

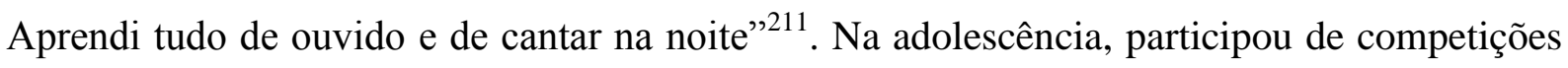
de laço a cavalo, esporte no qual se tornou campeão de várias provas: "Eu sempre morei em São Paulo, mas ia bastante para Sorocaba. Foi no haras do meu avô que tive meu primeiro contato com os cavalos e com a música sertaneja. Ainda na adolescência, eu me apresentava na abertura de eventos organizados por ele. Venci concursos de montaria. Ao sair do colégio, fui cursar agronomia no Paraná. Foi nessa época que a música falou mais alto"212.

Em 2007, enquanto cantava e tocava nos bares noturnos de Londrina foi apresentado, por amigos em comum, a Fernando Zorzanello ${ }^{213}$. No ano seguinte, foram contratados pela gravadora Universal e formaram o dueto Fernando e Sorocaba. Logo, emplacaram nas rádios

\footnotetext{
${ }^{209}$ Entrevista de Fernando Fakri Assis "Sorocaba" ao autor, 08 de abril de 2015.

${ }^{210}$ Idem, 08 de abril de 2015.

${ }^{211}$ Idem, 08 de abril de 2015.

${ }^{212}$ Idem, 08 de abril de 2015.

213 “Apesar do império sertanejo construído, a carreira musical de Sorocaba começou há pouco mais de dez anos. Aos 20 anos, à época em que era mais conhecido como Fernando Fakri de Assis, ingressou na faculdade de agronomia em Londrina e recebeu colegas de república o apelido de Sorocaba. Ainda durante os estudos, ele começou a compor e cantar pelos bares da cidade. Mas faltava um músico para fazer os arranjos e dividir os palcos. Foi então que conheceu Fernando Zorzanello, que tentava a carreira em Cuiabá. Fernando desistiu da capital de Mato Grosso e formou com ele uma dupla que não se cansa de fazer sucesso nos palcos e nos negócios até hoje”. Fonte: Isto é Dinheiro: O sertanejo milionário da capital, 10/10/2012.
} 
duas músicas que deram visibilidade à dupla: Bala de Prata e Paga Pau ${ }^{214}$. Inicialmente, ainda nos primeiros ensaios, os dois se deram muito bem e não só musicalmente: "O Fernando é um cantor excepcional e com um timbre diferenciado. Além de ser um multiinstrumental de sucesso e um produtor musical renomado. Ele produz os nossos trabalhos e também de artistas como Luan Santana, Chitãozinho e Xororó, Rio Negro e Solimões, Thaeme e Thiago e Marcos e Belutti"215. Desde então, a parceria entre eles vingou: "a gente se completa musicalmente e somos grandes amigos"216. Sorocaba é o compositor das canções e primeira voz do dueto. Nos shows, toca instrumentos como o violão, banjo de show, violino e gaita. Fernando é o responsável pela produção musical e aparece como segunda e primeira voz. Toca guitarra, violão, bateria e piano. Os músicos ficaram nos estúdios da Universal, entre 2007 e 2009. Em 2010, transferiram-se para a Som Livre ${ }^{217}$, gravadora responsável pelos músicos até 2014. Hoje, eles são gerenciados pela FS Produções Artísticas, escritório particular do artista. Lá, Sorocaba é também o responsável pelo agenciamento de novas promessas da música sertaneja:

O escritório está sempre em busca de artistas bons, todo escritório está. Artistas que fazem coisas iguais são os que mais têm, isso já não nos interessa. O que interessa é o que eu gosto de chamar de 'artistas conceituais', que trazem novas ideias, novas propostas, novos ares. Quem não queria achar um Luan Santana, que trouxe uma quantidade imensa de jovens para o sertanejo? Quem não queria um Victor e Leo, que trouxe um público que curtia MPB para o sertanejo? Todo mundo quer. O escritório, como eu disse, já está com um tamanho razoavelmente bom, mas artistas diferentes sempre terão portas abertas ${ }^{218}$.

No elenco comandado por Sorocaba, cada "artista conceitual" é destinado a atender um nicho específico do mercado consumidor da música sertaneja: Thaeme e Thiago seguem o estilo teen de Luan Santana e fazem sucesso entre os adolescentes; Marcos e Belutti adaptaram os elementos tradicionais da música sertaneja a um estilo moderno; Lucas Lucco é o galã-sertanejo da novela Malhação, exibida na Rede Globo; e Laubet é o caubói sensual da balada sertaneja ${ }^{219}$.

\footnotetext{
${ }^{214}$ Do álbum: Bala de Prata, 2008; música do CD Vendaval, lançada em 2009.

${ }^{215}$ Idem, 08 de abril de 2015.

${ }^{216}$ Idem, 08 de abril de 2015.

${ }^{217}$ Em 2010 a dupla estreia o CD e DVD ao vivo Fernando e Sorocaba - Acústico (Som Livre).

${ }^{218}$ Idem, 13 de maio de 2013.

219 "O Sorocaba mostrou que a música não é só um dom, mas é também um negócio lucrativo. Ele vai ficar marcado na história da música sertaneja, seja como artista ou como empresário”, André Piunti ao autor (2014).
} 
O contato com a música para Fernando Zorzanello aconteceu ainda na humilde infância: "Quando eu era criança, subia no guarda roupa do meu avô para pegar o violão dele e tocar. Fugia das lavouras para poder ficar tocando violão"220. Aos 15 anos, foi morar com seu pai Pablo Bonifácio, deixando sua cidade natal Ji-Paraná, no estado de Rondônia, para tentar a carreira musical em Cuiabá, no Mato Grosso: "Comecei a tocar profissionalmente aos 15 anos. Toquei muito tempo em banda de baile. Cantava axé, sertanejo, samba e modão de viola" $^{221}$. Zorzanello não tem título universitário, tampouco frequentou um conservatório ou teve aulas de música. Socializado com a profissão desde a infância, ainda na adolescência, passou a viver exclusivamente da música. Sua formação instrumental foi autodidata e na experiência como músico de estrada. Fernando enfrentou percalços até o sucesso bater às portas: fez vários projetos, duplas, bandas, carreira solo etc. Em 2007, conheceu Sorocaba em Londrina, mudando os rumos de sua trajetória profissional.

Nas revistas, jornais e sites pesquisados, os músicos não fazem exaltação de uma música sertaneja "autêntica". Abertamente, admiram Chitãozinho e Xororó. Aliás, eles têm pouca inibição em assumir as influências do rock, pop e country em suas canções. A identidade musical sertaneja aparece sem conflitos. Até mesmo o termo universitário não é repudiado, apenas evitado:

Fazemos música sertaneja, mas aceitamos a confluência de outros ritmos, como o country americano e o pop internacional. Acreditamos que essa junção de ritmos só agrega e quem ganha com isso é o público. A música sertaneja está aberta às misturas. No nosso trabalho Sinta Essa Experiência, gravamos a canção Imagina Na Copa com a participação do Monobloco e a mistura deu certo, e o resultado foi surpreendente. No nosso show atual, a Tour 2015, tem um bloco em que o Fernando canta modas de viola. Essa é a nossa raiz ${ }^{222}$.

No período entre 2007 e 2015, produziram nove discos ${ }^{223}$. O investimento tecnológico sempre foi uma marca registrada da dupla ${ }^{224}$. Em outubro de 2011, na gravação do quarto

\footnotetext{
${ }^{220}$ Entrevista de Fernando Zorzanello ao programa Fantástico (Rede Globo), exibida em: 19/10/2014.

${ }^{221}$ Entrevista de Fernando Zorzanello ao programa Fantástico (Rede Globo), exibida em: 19/10/2014.

${ }^{222}$ Sorocaba. Fonte: do autor (2015).

${ }^{223}$ Discografia em ordem de lançamento: Ao Vivo em Londrina (2006); Bala de Prata Ao Vivo (2008); Vendaval (2009); Acústico (2010); Bola de Cristal Ao Vivo (2011); Acústico na Ópera de Arame (2012); Homens e Anjos (2013); Sinta Essa Experiência (2014); EP Sem Reação (2014) e Anjo de Cabelos Longos (2015).

224 "Uns $90 \%$ pelo menos do que a gente grava e canta nos shows são coisas nossas. O show é muito autoral, então, a fonte principal é a própria dupla. É fato que o Luan tem um papel importantíssimo nessa história, já que grandes sucessos dele são composições minhas e elas tocam muito até hoje, em rádios e em shows. Mas nossos shows e CD's pesam muito, o fato de serem autorais é o que me fez chegar nesse primeiro lugar". Entrevista de Sorocaba ao portal Universo Sertanejo, 13/05/13.
} 
DVD, Ópera de Arame, sediado em Curitiba (PR), eles fizeram um projeto audacioso: mapearam em 3D cada centímetro do local, projetando o cenário com efeitos visuais. Não pararam por ali. Depois, penduraram-se em uma grua a uma altura de vinte metros acima do público. Atualmente, um dos momentos mais esperados pelo público é a bolha: os músicos entram em uma enorme bolha de plástico que caminha no meio da plateia até chegar ao palco. Fora o disco voador que Sorocaba pilota por cima da cabeça dos espectadores: "Eu gosto de inovar sempre, pois nossos fãs merecem. O público vai ao show querendo ver música aliada à diversão"225.

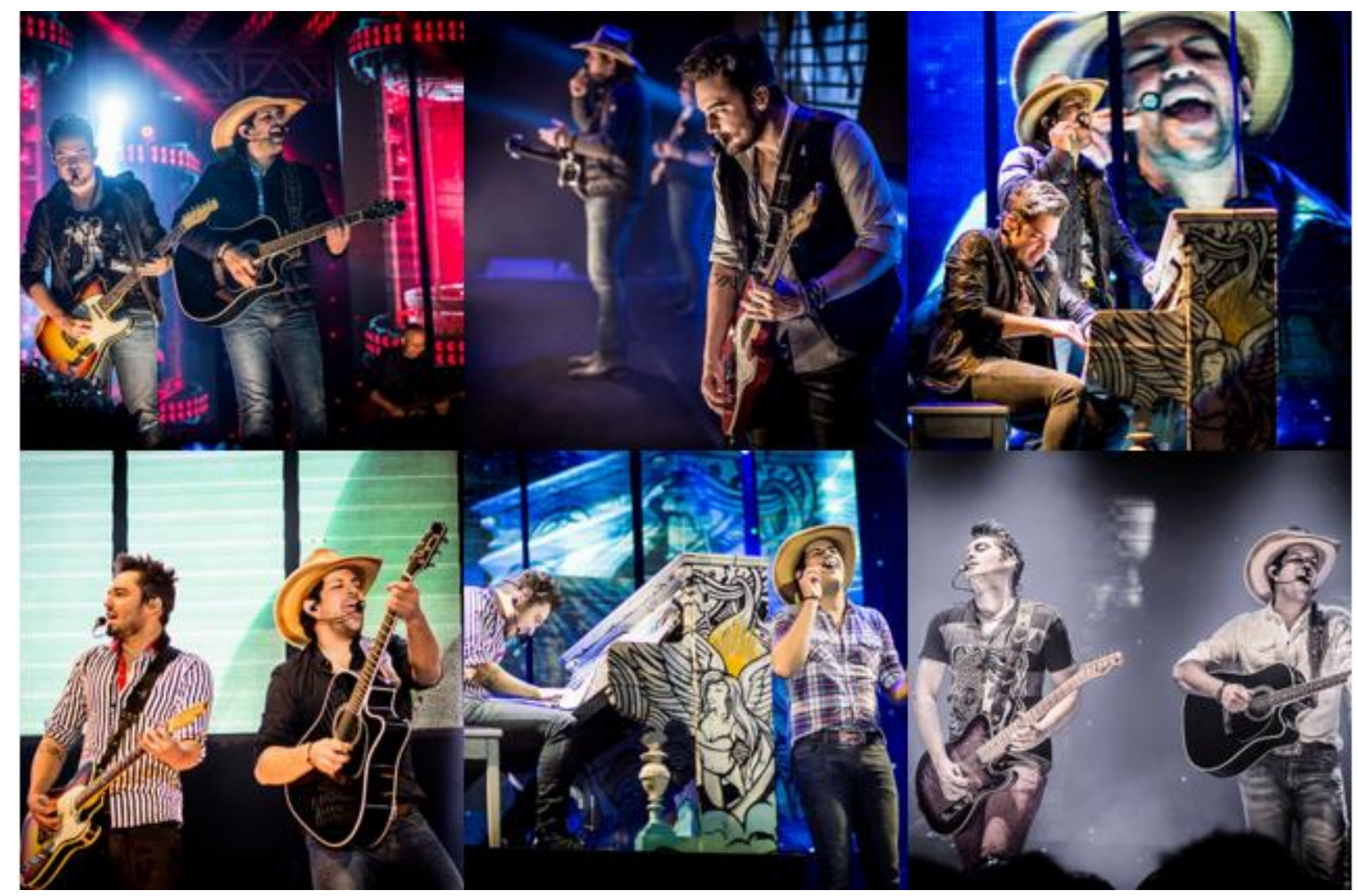

Nos shows, Fernando e Sorocaba não abrem mão dos efeitos visuais e ilusionistas em 3D. Os monitores digitais atraem a atenção da plateia que é convidada a participar do show-balada. Foto: site oficial da dupla.

Estive em duas apresentações da dupla ${ }^{226}$ e notei as “invenções" de Sorocaba: monitores LED's que projetavam efeitos ilusionistas por toda parte, piano psicodélico, videoclipe de abertura com avião aterrissando no palco, bonecos gigantes e caricatos dançando com os músicos, e aparições de Fernando e de Sorocaba no meio da plateia. Também causaram furor em Maringá, no Paraná, com a estreia do projeto FS Loop 360 graus,

\footnotetext{
${ }^{225}$ Entrevista de Fernando Fakri de Assis "Sorocaba” ao autor, 08 de abril de 2015.

${ }^{226}$ Citibank Hall, no dia 27 de setembro de 2014, e Terra Country Interlagos, no dia 10 de outubro de 2014.
} 
no qual dois artistas se apresentam ao mesmo tempo ou de forma intercalada por três horas consecutivas em dois palcos. Sorocaba se gaba: "Ter o seu trabalho reconhecido em todo o Brasil é uma sensação indescritível"227 . Em uma década, o agrônomo conseguiu formar um "império sertanejo". Ocupa as primeiras posições na arrecadação de direitos autorais, possui casa noturna de música sertaneja em São Paulo, tem seu próprio escritório e estúdio comercial $^{228}$, foi o compositor das músicas consagradas por Luan Santana e administrador da carreira de cinco artistas sertanejos. Sorocaba sempre conseguiu administrar muito bem a carreira musical e empresarial $^{229}$. O artista-empresário costuma "profetizar" que uma carreira estável tem três pilares que se sustentam, portanto, ele mesmo se dedica a cada um dos "pilares" da carreira. O primeiro pilar é o repertório, talvez o principal: “Temos a vantagem de nosso trabalho ser muito autoral, ter a nossa cara e estar dentro do nosso controle" ${ }^{\text {230 }}$. O segundo pilar é o show, o qual se investe muito dinheiro atrás de novas tecnologias digitais para inovar os espetáculos. O terceiro pilar é o escritório, o trabalho feito por trás dos palcos, as estratégias pensadas pra manter a carreira do artista: "Se você tem esses três aspectos bem formados, quando um deles não vai tão bem, o outro ajuda a segurar, equilibrar as coisas"231.

No dia 18 de novembro de 2014, a dupla lançou o primeiro EP (sigla em inglês para Extended Play, um espécie de CD com apenas três ou cinco faixas) da carreira: Fernando \& Sorocaba - Sem Reação, pelo iTunes (plataforma digital desenvolvida pela empresa Apple para compra de mídia digital). Em um único dia, eles tiveram mais de 20 mil visualizações no canal Youtube, recebendo 10 mil tweets (seguidores que compartilharam a mensagem) na rede social Twitter. Na semana anterior, o escritório de Sorocaba foi obrigado a mudar a capa sob a acusação de plágio. O desenho era semelhante à capa do CD do cantor norte-americano

\footnotetext{
${ }^{227}$ Entrevista de Fernando Fakri de Assis "Sorocaba" ao autor, 08 de abril de 2015.

${ }^{228}$ Atualmente, a FS Produções Artísticas e a Audiomix são os dois maiores escritórios e competem pela mesma fatia de mercado da música sertaneja: "Não sei se a palavra "concorrente" define bem, talvez passe uma ideia errada. São os dois mais representativos, hoje, mas há outros importantes também. Eu não gosto de falar em concorrência por poder passar algo negativo, a variedade é extremamente necessária. Essa espécie de "disputa" é sadia para o mercado, quando é feita de forma honesta. Já imaginou se não houvesse o nosso ou não houvesse o deles, se existisse um monopólio? Existindo frentes diferentes, fica aquela necessidade de sempre tentar algo novo, querer crescer, querer ser melhor, e quem ganha com isso, no final das contas, é o sertanejo", Fonte: Idem, $13 / 05 / 2013$.

229 “É verdade que nós trabalhamos hoje com muito gás, com o acelerador no talo, e não sei se é possível manter esse nível por anos e anos. Mas sou solteiro e tenho meu tempo todo pra música, então eu trabalho no limite pra conseguir os melhores resultados possíveis". Entrevista de Sorocaba ao portal Universo Sertanejo, 13/05/13.

${ }^{230}$ Entrevista de Sorocaba ao portal Universo Sertanejo, 13/05/13.

${ }^{231}$ Entrevista de Sorocaba ao portal Universo Sertanejo, 13/05/13.
} 
John Mayer (título: Born and Raised). O escritório FS Produções Artísticas, rapidamente, alterou a capa e enviou uma carta oficial à imprensa. A reportagem: "Após acusação de plágio, Fernando e Sorocaba mudarão capa" do site $U O L^{232}$ trouxe a declaração do designer David Smith, responsável pela capa do álbum de John Mayer. Smith disse nas redes sociais que se sentiu "lisonjeado" com a "semelhança".

Em São Paulo, eles se apresentam nos seguintes espaços: Villa Mix (Vila Olímpia), Villa Country (Água Branca), Coração Sertanejo (Socorro), Espaço Fazenda (Alphaville), Rancho da Vila (Vila Madalena), Terra Country (Interlagos), Citibank Hall (Santo Amaro) e Estância Alto da Serra (São Bernardo do Campo). A agenda musical paulistana de Fernando e Sorocaba e de Victor e Leo foi monitorada durante o segundo semestre de 2014 (ANEXO B). Desde 2010, eles participam da Festa de Peão de Boiadeiro de Barretos. Além da capital e da grande São Paulo, a dupla sertaneja faz shows em rodeios por todo o interior do país. O show de Fernando e Sorocaba é considerado, entre os contratantes do mercado fonográfico, como um dos principais do segmento. Em 2014, o portal de notícias Movimento Sertanejo divulgou uma pesquisa apontando que o público elegeu o show da dupla como o melhor do ano (aprovação de 25,92\%). Victor e Leo ficaram na sétima posição $(3,46 \%)^{233}$. O ranking demonstra a centralização do mercado de shows para os primeiros músicos.

Diferentemente de Victor e Leo, Fernando e Sorocaba ainda dependem mais das apresentações, eventos e shows por todo o Brasil. Em um mesmo mês, Fernando e Sorocaba sobem nos palcos de diversos estados brasileiros, vão às festas do peão de boiadeiro do interior longínquo, exibem-se nas renomadas casas de espetáculos metropolitanas e tocam nos bares noturnos da capital paulistana. Isso também quando não aparecem na agenda da indústria do entretenimento norte-americana. Enquanto os irmãos mineiros estão mais presentes nos programas de auditório da TV, são figuras carimbadas na programação ao vivo das rádios ou estampam as capas de revistas de entretenimento, Fernando e Sorocaba submetem-se a uma rotina de shows mais exaustiva, em média, fazem 219 apresentações anuais $^{234}$.

\footnotetext{
${ }^{232}$ UOL Música: Após acusação de plágio, Fernando e Sorocaba mudarão capa de CD, 10/11/2014.

${ }^{233}$ Movimento Country: Show de Fernando e Sorocaba é eleito o melhor show do ano, 08/12/2014.

${ }^{234}$ Revista $C Q$ : CQ investiga a vida de Sorocaba, o milionário músico da nova geração de sertanejos brasileiros, $24 / 02 / 2012$.
} 
Abro espaço para algumas considerações. O investimento pesado em inovações tecnológicas encabeçado por Sorocaba não é novidade alguma no gênero. Na década de 1990, Chitãozinho e Xororó carregaram toneladas de equipamentos em ônibus particulares. No entanto, hoje, essa prática não é mais uma regra para o sucesso dos novos músicos sertanejos. Embora Fernando e Sorocaba tenham uma carreira musical sólida e uma agenda de shows nos quatro cantos do país, o acesso a outros meios de comunicação é mais limitado. As músicas do dueto não foram enredos de novela e eles não aparecem de forma tão assídua nos programas de TV com grande audiência (com exceção das rádios). Entretanto, usam e abusam das novas plataformas digitais. O duo sertanejo depende do mercado de shows e dos subcircuitos da música sertaneja (feiras e festas agropecuárias e festas do peão de boiadeiro). O uso de tecnologias é a grande estratégia artística de Sorocaba. Essa espécie de capital tecnológico/artístico é atraente aos olhos dos patrocinadores da música sertaneja, porque promove shows superlotados e com enorme vendagem de bilheteria. Isso explica o pouco interesse do artista para as questões de direitos autorais ou de reprodução digital das músicas. Se o marketing lucrativo de Fernando e Sorocaba está voltado às apresentações ao vivo, a receita do sucesso econômico de Victor e Leo está tanto no show business quanto no mercado tradicional de CD's e DVD's:

Victor e o Leo são artistas que têm uma postura mais antiga em relação à
gravadora. Fernando e Sorocaba não são assim. Inclusive, eles romperam e
saíram do selo Som Livre por conta própria. Hoje, a Som Livre aposta muito
na carreira de Victor e Leo, afinal eles vendem muito bem e possuem um
discurso que agrada as gravadoras: não promovem a distribuição de discos
gratuitos ou de download ilegal. Então, eles vendem. Lógico que pela
qualidade dos discos, mas eles trabalham para que esses discos sejam
vendidos. Nas entrevistas, defendem um discurso em prol da venda legal dos
discos. Fernando e Sorocaba nunca vão aparecer em certos rankings ou
mídias porque eles são totalmente a favor da música livre ${ }^{235}$.

No portal Universo Sertanejo, André Piunti fez uma oportuna pergunta ao empresário sertanejo: se a renda vinda dos direitos autorais das composições é tão primordial a Sorocaba, por que ele é a favor da chamada "música livre”? "Eu vivo esse dilema. Estamos em uma fase de transição e soluções vão aparecer com o tempo. Há muita gente se mexendo pra que todos possam ganhar e aproveitar os benefícios da internet. Eu realmente não consigo te responder da forma que eu gostaria, pois estamos todos nos acostumando com um cenário novo. O que

${ }^{235}$ André Piunti. Fonte: do autor (2014). 
eu acho importante é que todo mundo possa receber por seu trabalho"236. No início da carreira, Sorocaba divulgava e distribuía CD's promocionais nos shows. Dezenas de artistas da geração do sertanejo universitário se beneficiaram dessa estratégia. No entanto, pouco a pouco, essa prática foi sendo abandonada. E não por uma questão ética: Sorocaba, por exemplo, tornou-se empresário do gênero:

Essa foi uma estratégia que deu muito certo e foi muito importante, mas, em minha opinião, já passou. Eu já não acredito que seja uma boa estratégia para 2013. Eu vejo muita gente olhando para trás, buscando referências, mas não estão percebendo que nosso segmento está mudando as estratégias muito rapidamente. No presente, nosso escritório é muito mais voltado para o digital, acompanhamento do iTunes, Youtube, redes sociais, novas oportunidades. Com uma estrutura digital bem equipada, o escritório tem muito mais força do que se distribuísse $\mathrm{CD}$ na mão das pessoas. Claro que os promocionais continuam aí, nas campanhas de rádio, em alguma premiação em show, alguma divulgação pontual, mas, grosso modo, quem estiver voltado para o digital vai ter mais sucesso ${ }^{237}$.

Esse conceito de "música livre" adotado por Sorocaba trouxe muita dor de cabeça ao escritório Som Livre. Hoje, essa ideologia promovida pelo músico foi se degradando, afinal, ele não é mais um mero artista sertanejo: é também um empreendedor sertanejo ${ }^{238}$.

Dados coletados do ECAD ${ }^{239}$, no período de 2008 a 2015, indicam os nomes de Sorocaba e Victor Chaves entre os maiores arrecadadores de direitos autorais. As avaliações feitas pelo ECAD incluíram diversos segmentos do cenário nacional e internacional. Hoje, os dois compositores não são protagonistas apenas na música sertaneja - estão no rol dos músicos mais bem-sucedidos do Brasil ${ }^{240}$. Por cinco anos ininterruptos, eles disputaram a primeira colocação no índice de arrecadação de direitos autorais, ranking que abarca os itens:

\footnotetext{
${ }^{236}$ Idem, 13 de maio de 2013.

${ }^{237}$ Universo Sertanejo: Bastidores: Entrevista de Sorocaba, 13/05/2013.
}

238 “O mercado sertanejo não conhece crise. Em 2011, a indústria fonográfica comemorou o aumento suado de $8,4 \%$ na venda de CD's e DVD's e música digital em relação ao ano anterior. Embora boa parte desse crescimento se deva ao aumento do poder aquisitivo da classe $\mathrm{C}$, que consome música sertaneja com gosto, a turma do chapelão há muito não depende exclusivamente de vender discos. Uma das estratégias de divulgação propagadas por esse pessoal, aliás, é a doação de CD’s. Foi assim que Fernando Fakri de Assis, o Sorocaba, ganhou seu primeiro quinhão de fãs: Produzia meus próprios CD's, prensava mil cópias e distribuía nas cidades em que ia me apresentar. No dia do show, todo mundo já conhecia as músicas”. Fonte: Revista Veja: O Brasil virou sertão, p.88, 30/01/2013.

${ }^{239}$ O Escritório Central de Arrecadação e Distribuição (ECAD) é uma instituição privada, sem fins lucrativos, instituída pela lei 5.988/73 e mantida pela Lei Federal 9.610/98 e 12.853/13. Seu principal objetivo é centralizar a arrecadação e distribuição dos direitos autorais de execução pública musical.

${ }^{240}$ Os valores repassados não são divulgados pelo ECAD. 
shows, rádio, música ao vivo, casas de festas, casas de diversão e sonorização ambiental. Em 2008, Sorocaba ainda não despontava em nenhuma colocação na lista. Entretanto, Victor Chaves angariou a primeira colocação no ranking de arrecadação em direitos autorais (cobrados com base na receita da venda de ingressos dos shows). O compositor teve um grande número de faixas cantadas por outros artistas também, o que lhe impulsionou o primeiro lugar. Ainda incipiente, a pesquisa não tinha subdivisões claras (com exceção de música executada ao vivo) para esclarecer a divisão de lucros aos participantes. No ano seguinte (2009), Sorocaba surgiu no ranking pela primeira vez, na $13^{\circ}$ ocupação, com apenas um ano de carreira ao lado de Fernando Zorzanello. Novamente, Victor conseguiu a primeira posição como autor com maior rendimento em todos os setores (shows, rádio, música ao vivo, casas de festas, casas de diversão e sonorização ambiental).

O ECAD, então, passou a adotar regras mais estritas para divulgação dos dados musicais, incluindo direitos autorais aos demais subitens. Velozmente, Sorocaba estreou na $2^{\circ}$ colocação em 2010. Esse rápido crescimento se deve à popularização de suas composições por Luan Santana. Já o compositor mineiro conquistou a liderança pela terceira vez consecutiva como o maior titular (compositor, intérprete e músico) na arrecadação de direitos autorais em todos os seguimentos (shows, rádio, música ao vivo, casas de festas, casas de diversão e sonorização ambiental). De acordo com o escritório, nos anos de 2011 e de 2012, as posições se inverteram: Sorocaba foi o primeiro da lista e Victor passou à segunda posição de titulares (compositor, intérprete e músico) com maior arrecadação de direitos autorais em todos os seguimentos já citados. Ao todo, Victor permaneceu por cinco anos no topo da lista: em 2008, 2009 e 2010, na primeira colocação, e em 2011 e 2012, na segunda posição. Sorocaba, que sequer entrou no ranking de 2008, despontou na $13^{\circ}$ posição no ano de 2009 e, drasticamente, passou à vice-liderança em 2010, depois ocupando o primeiro lugar por dois anos consecutivos, entre 2011 e 2012 , respectivamente ${ }^{241 .}$

Entretanto, em 2013, houve um sumiço de Victor Chaves no topo do ranking (as dez primeiras colocações). Atribuo-o ao sucesso relâmpago de Michel Teló com o hit, Aí Se Eu Te Pego, no ano anterior, 2012. Timidamente, o músico mineiro ocupou a $16^{\circ}$ colocação no item rádio, com a canção Quando Você Some. Sorocaba, ainda no ano de 2013, foi o segundo maior arrecadador de direitos autorais. Em 2014, ele ocupou a terceira posição de maior

\footnotetext{
241 "Desde então, o ECAD não divulga quem foi o compositor que mais arrecadou em geral na soma de segmentos, apenas as listas de cada setor, como shows, casas de diversão, casas de festa e rádio". Fonte: Rodrigo Ortega/G1: Sorocaba bate Roberto Carlos e lidera o ranking de direito autoral em shows, 18/01/2016.
} 
titular, enquanto Victor ocupou o $5^{\circ}$ lugar, ambos no item de execução em rádios. Em 2015, pela terceira vez, Sorocaba voltou à liderança no ranking de arrecadação de direitos autorais em shows. No mesmo item, Victor Chaves angariou a $18^{\circ}$ colocação. Certamente, ocupar as primeiras posições no ranking do ECAD destaca o sucesso comercial tanto de Victor quanto de Sorocaba. Ademais, a arrecadação de direitos autorais assinala um marcador de prestígio, que é traduzido no alto valor dos cachês pagos pelos contratantes do gênero:

Minha relação com o ECAD é boa, e eu acredito que ainda não exista uma solução melhor que o ECAD, mas sou aberto a discussões e propostas novas. Acho que essa questão de direitos autorais precisa ser resolvida logo, pois há centenas de compositores que precisam receber de forma justa e rápida, já que dependem disso pra viver. Eu tenho muita curiosidade em saber como funciona essa questão nos Estados Unidos e na Europa. Não apenas o que diz a lei, mas como se consegue fiscalizar de forma eficaz e justa. Que eu saiba, não há essa briga imensa em outros países, é uma coisa muito nossa. Acho que a gente não pode fechar os olhos pra ideias novas, como muitos fazem. Eu mesmo conheço um projeto novo que vai monitorar a execução de músicas em rádios de forma extremamente confiável. A gente tem que estar de olho em propostas novas, justamente, porque é de nosso interesse ${ }^{242}$.

O empresário sertanejo não é dono de um espírito devotado à camaradagem no meio artístico ou tampouco no ramo dos negócios - Fernando Zorzanello que o diga. O relacionamento entre Fernando e Sorocaba é puramente comercial e válido somente no mercado do show business da música sertaneja. Atrás das cortinas, o músico é um mero funcionário contratado pelo escritório FS Produções Artísticas. Sorocaba sequer divide os lucros dos shows ${ }^{243}$ com o seu "parceiro" Fernando, que é pago por uma espécie de salário/cachê acertado entre os dois ${ }^{244}$. De 2005 a 2007, Humberto Santiago foi o primeiro "Fernando" da formação original com Sorocaba. Em 2014, o ex-parceiro foi reconhecido pela Justiça do Amapá como coautor da marca "Fernando e Sorocaba". Humberto alegou que foi dispensado em 2007 por Sorocaba, que registrou apenas em seu nome o uso da marca - que vale atualmente R\$ 70 milhões $^{245}$. Em um comunicado feito à imprensa ${ }^{246}$, a assessora de Fernando Fakri de Assis justificou que: "Sorocaba teve a ideia de criar a marca utilizando a composição do seu nome de batismo Fernando e seu apelido Sorocaba. O músico Humberto

\footnotetext{
${ }^{242}$ Portal Universo Sertanejo: Bastidores: Entrevista com Sorocaba, 13 de maio de 2013.

${ }^{243}$ FM Hits: Os 10 cantores sertanejos que mais lucraram em 2013, 05/06/2014.

${ }^{244}$ Valor desconhecido e não informado.

${ }^{245}$ Portal Ego/Globo: Ex-parceiro de Sorocaba ganha na Justiça direito nome da dupla, 28/08/2014.

${ }^{246}$ UOL Entretenimento: Cantor sertanejo Sorocaba é processado por ex-integrante da dupla, 21/08/2014.
} 
Santiago, quando contratado, tinha ciência da existência da marca e qual função desempenharia no projeto. Seu desligamento ocorreu no ano de 2007 dentro dos trâmites legais e em comum acordo" 247 . Entretanto, o veredicto judicial pôs em xeque essa versão: o empresário paulista teria registrado a marca "Fernando e Sorocaba", em outubro de 2006. Portanto, se o "desligamento ocorreu no ano de 2007", como Santiago "teria ciência da existência da marca", se ela foi patenteada um ano antes do fim da dupla? Nas audiências, o advogado Rivaldo Valente defendeu que Humberto tem baixa escolaridade, não conhecia os direitos dele e confiava muito em Sorocaba. "Temos o DVD deles em Londrina, entrevistas e documentos nos quais Sorocaba reconhece Humberto como o 'Fernando'. Está clara a relação societária dos dois" ${ }^{248}$. Depois da sentença (28 de agosto de 2014), a assessoria de Sorocaba enviou um novo comunicado oficial: "Reafirmamos nossa convicção de que ação proposta é inadequada e improcedente, bem como de que conseguiremos demonstrar que o Sorocaba é o verdadeiro e único criador da marca Fernando e Sorocaba"249. Por fim, eu trouxe essa questão a Sorocaba, durante as entrevistas, mas ele disse não ter permissão dos advogados para falar sobre esse assunto ${ }^{250}$.

Fernando Fakri de Assis foi receptivo ao meu acesso à dupla. Não fez restrições. Permitiu até minha presença no palco, durante o show realizado no espaço Terra Country Interlagos. É um artista carismático, sem histórico de agressividade com o público ou com a imprensa (diferentemente de Victor Chaves). Sorocaba não acumula apenas a função de artista sertanejo: é um dos maiores empresários deste negócio milionário que é a música sertaneja. Um negócio que move cifras anuais acima dos R \$ 370 milhões ${ }^{251}$ - sendo ele um dos maiores faturadores dessa fatia de mercado. Hoje, ele é o responsável por um conglomerado sertanejo que envolve gravadora, escritório, casa de espetáculos e tudo que seja rentável em relação à música sertaneja ${ }^{252}$. Sua figura social é instigante: reúne uma dupla

\footnotetext{
${ }^{247}$ Idem, 21/08/2014.

${ }^{248}$ Idem, 21/08/2014.

${ }^{249}$ Idem, 28/08/2014.

${ }^{250}$ Entrevista de Fernando Fakri de Assis "Sorocaba" ao autor, 08 de abril de 2015.

${ }^{251}$ Entrevista de Marcos Mioto para o programa Fantástico (Rede Globo), exibida em 19/10/2014.

252 "Sorocaba não revela o faturamento da empresa, mas afirma que o mercado sertanejo é um dos maiores da indústria fonográfica do país. "Todos os anos dobramos de tamanho", diz ele sobre o escritório que tem quatro anos de existência. Para promover os artistas do seu próprio escritório, Fernando e Sorocaba usam sua imagem de dupla bem-sucedida. Em seu último DVD, além de Luan Santana, Thaeme e Thiago e Inimigos da HP - que estão no portfólio da produtora - fizeram uma ponta no show. Com o olhar apurado para os negócios, o sertanejo comprou, no mês passado, 20\% dos direitos da revelação dos Santos, Victor Andrade, 17 anos. O jogador está avaliado em 50 milhões de euros". Fonte: Idem, O sertanejo milionário da capital, 10/10/2012.
} 
participação artística e empresarial na música sertaneja, veste-se de forma excêntrica como um caubói norte-americano e encena no show uma balada de rock rural ${ }^{253}$. Em menos de um ano, ele despontou no cenário musical, na esteira do movimento universitário, e logo se esbarrou com o sucesso de Victor e Leo. Os irmãos foram severos críticos da "pouca originalidade" musical dos sertanejos universitários. Na imprensa, os mineiros saíram em defesa de uma suposta autenticidade da tradição sertaneja. Victor e Leo foram recebidos de braços abertos por ícones da MPB-caipira, como Renato Teixeira e Almir Sater - artistas que promoveram as clivagens entre música caipira e música sertaneja, nos anos 1970, 1980, 1990 e, que agora, estavam dispostos a apoiar os músicos, os condecorando como "verdadeiros" artistas sertanejos.

A tradição da música sertaneja universitária, como é bem exemplificada na carreira de Sorocaba, não estava em uma suposta "raiz" de um passado efabulado, mas em trajetórias musicais como Leandro e Leonardo, Zezé Di Camargo e Luciano e Chitãozinho e Xororó nomes do boom comercial da música sertaneja romântica dos anos 1990, que iniciaram um diálogo com um público mais urbanizado. O selo de legitimação na carreira de Sorocaba não está tanto no cunho do simbólico. Sua consolidação musical faz parte de um processo social mais complexo, que tem impulsionado a formação de uma nova classe-média brasileira, surgida progressivamente a partir dos anos 2000. Um novo público-consumidor que passa a ter acesso às universidades - uma instituição que agora coexiste com certos estratos da população, antes excluídos de uma cultura escolar. A produção artística de Sorocaba tem outra legitimidade: a comercial. Não mais garantida na lógica anterior de vendagem de álbuns, mas dos shows ao vivo que embalam as festas, dentro e fora dos circuitos agropecuários $^{254}$. Ivan Vilela está certo: “a balada agora é pop”.

Como já foi apresentado na introdução, o quadro Bem Sertanejo do programa Fantástico reuniu Victor e Leo e Fernando e Sorocaba. O jornalista André Piunti foi um dos

\footnotetext{
253 "Outro destaque da nova geração, Fernando e Sorocaba estão mais para astros do rock que para artistas sertanejos. Os shows da dupla são repletos de efeitos que fazem a alegria dos amantes do hard rock, como solos de guitarra (cortesia de Fernando, confortável no papel de guitar hero) e fogos de artifício. Às vezes, soltam até releituras sertanejas de Pais e Filhos da Legião Urbana e Sweet Child O'mine do Guns N'Roses". Fonte: Idem, p.92, 30/01/2013.

254 “A principal fonte de renda dos artistas sertanejos é essa, a apresentação ao vivo. E como eles se apresentam. Um nome do primeiro - e até do segundo - escalão faz entre quinze e vinte apresentações por mês, com cachês que vão de duzentos mil a trezentos e cinquenta mil reais - ou até quinhentos mil reais: 'Oitenta por cento da agenda de um sertanejo vai para os rodeios, feiras de agronegócio e festas de exposições', diz Marcos Mioto, um dos mais respeitados profissionais do show-biz. Não é para menos: todos os anos, cerca de mil e quinhentos rodeios acontecem no país, eles movimentam algo como dois bilhões de reais" Fonte: Idem, p.88, 30/01/2013.
} 
roteiristas do programa e, claro, pensou nesse conflito entre as duas duplas. O programa reuniu os dois músicos que mais faturam dinheiro com direitos autorais no Brasil desde 2007 - Victor Chaves e Fernando Fakri de Assis “Sorocaba”. Para Piunti, os dois compositores têm perfis completamente diferentes - Victor é o inspirado enquanto Sorocaba é o racional: "Sorocaba é um artista extremamente técnico, realista e frio. Em contrapartida, Victor tem toda aquela aura de poeta inspirado, apesar de não ser tão ingênuo assim. Ele não é um compositor que escreve e compõe num único dia - senta e escreve uma música em cinco músicas. Victor é mais inspirado do que prático, mas tem plena consciência da produção técnica. Sorocaba está num extremo aposto: na realidade" 255.

$\mathrm{Na}$ falta de um consenso bibliográfico ou documental que apontasse a história social do movimento universitário na música sertaneja, busquei respostas em seus próprios produtores. À medida que os assistia, pude compreender então o significado de tal sufixo, em um gênero considerado "menor" aos olhos da elite intelectualizada ou artística brasileira. Em menos de três décadas, uma música antes tida como subalterna, suburbana ou periférica tornou-se "universitária". O termo revelava ser um nicho de mercado pensado pela indústria fonográfica para atualização do estilo. O rótulo universitário auferiu poder simbólico ao gênero e, ao mesmo tempo, simbolizou uma clara estratégia de reconversão social dos novos músicos sertanejos para serem aceitos por plateias que antes não o consumiriam jamais inclusive, o público da classe-média alta da capital paulistana:

Nos últimos tempos, as casas noturnas, reduto das classes A e B, também se renderam ao chacundum. A pioneira foi a Villa Country, na zona oeste de São Paulo. Em uma década de existência, ela não apenas promove o namoro apaixonado entre a juventude abastada e o sertanejo, como revelou duplas de sucesso como Victor e Leo. Neste momento, o universo sertanejo é só alegria, em todas as suas esferas. O consumidor de música sertaneja, por exemplo, é jovem. A média varia de 25 a 44 anos. Gosta de festa e gosta de beber - como gosta de beber: 'Sou o maior vendedor de vodca e energético do país', jacta-se Rafael Setrak, proprietário da filial paulistana da discoteca Wood's, voltada para 'a classe A'. A balada sertaneja também é ideal para a conquista. Mais de $50 \%$ do público pertencem ao sexo feminino e as composições refletem essa alma festeira ${ }^{256}$.

Essa tensão sexual citada na reportagem não está restrita apenas ao ambiente da balada sertaneja. No capítulo 5, examinarei as interações eróticas entre a plateia masculina e feminina no show de Fernando e Sorocaba.

\footnotetext{
${ }^{255}$ Entrevista de André Piunti ao autor, 22/11/2014.

${ }^{256}$ Revista Veja: O Brasil virou sertão, p.88-89, 30/01/2013.
} 


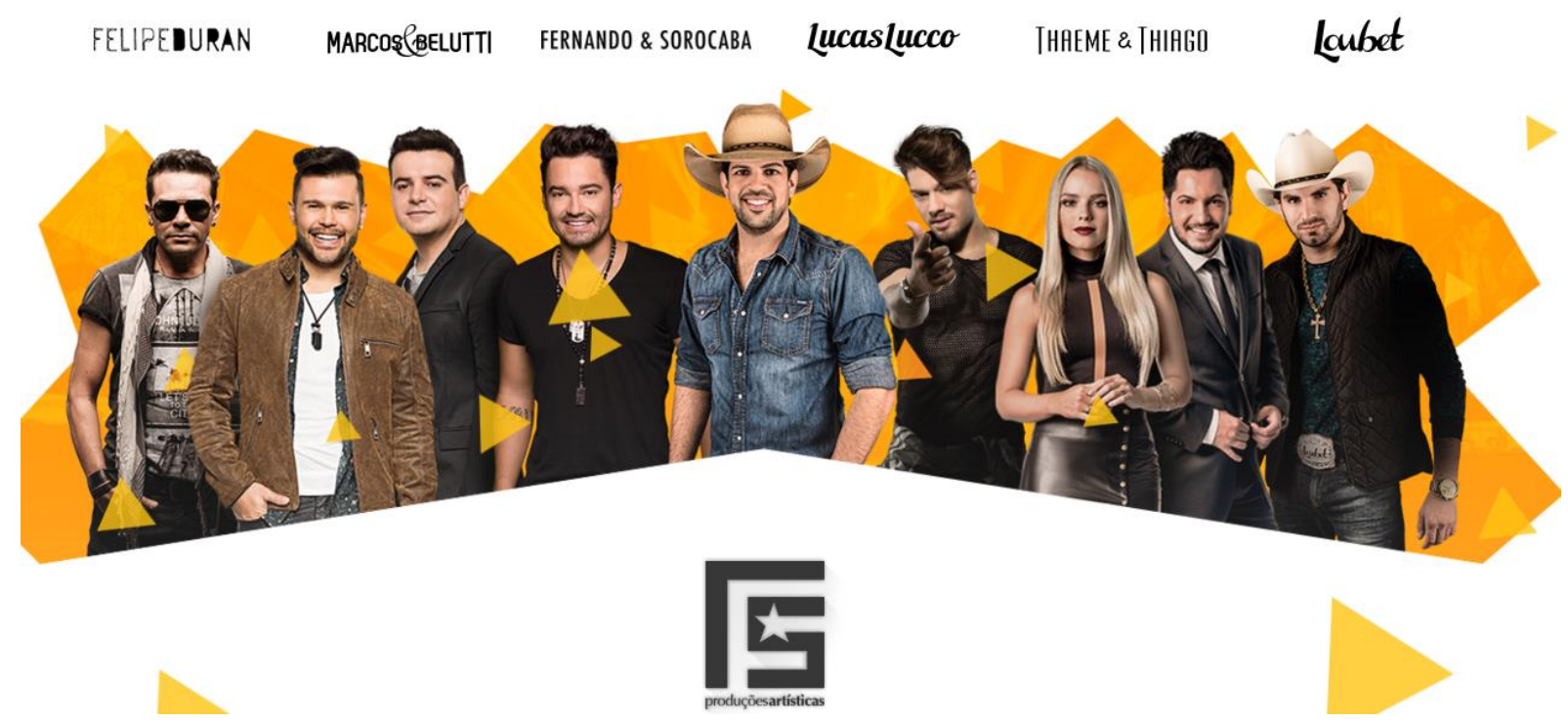

Os sertanejos "conceituais" agenciados pelo escritório de Fernando Fakri de Assis "Sorocaba". A ambição do empresário vai além de "novas ideais, novas propostas ou novos ares". Cada artista do elenco atende uma cota específica do mercado sertanejo: Felipe Duran é apenas o instrumentista folk; Marcos e Belutti são os músicos que não abrem mão de uma pitada de tradição; Lucas Lucco é o galã sensual que exibe o corpo definido; Thaeme e Thiago têm rostos bonitos e agradáveis que chamam a atenção do público adolescente (aliás, esse é o segundo "Thiago" da dupla); e Laubet tem o estereótipo do caubói moderno. Foto: site oficial da dupla.

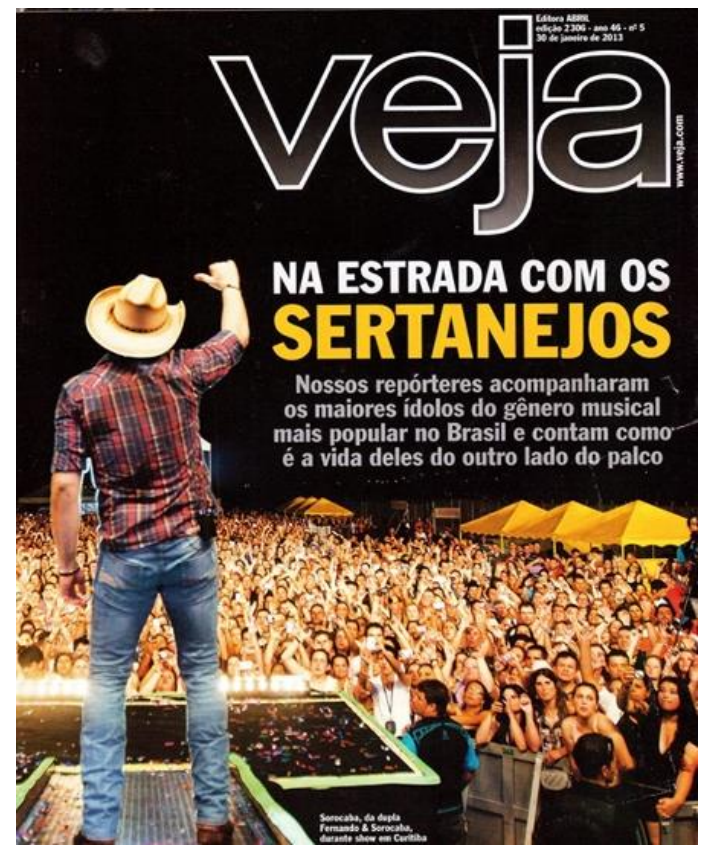

Sorocaba, na capa da revista Veja (30 de janeiro de 2013). Na sessão "Carta ao Leitor", o corpo editorial da revista é enfático: "Está se falando aqui de um negócio com faturamento anual estimado em cerca de R\$ 1 bilhão, computadas apenas as rendas dos maiores vendedores de discos de música desse gênero. Zezé Di Camargo e Luciano, Bruno e Marrone, Fernando e Sorocaba e Michel Teló venderam juntos mais de 45 milhões de discos na carreira. Essa vendagem já seria suficiente para entronizá-los como ícones históricos da cultura de massa no Brasil. Mas, os discos são apenas parte do espetáculo. Se não forem seguidos de shows ao vivo de norte a sul do Brasil, a popularidade do artista cairá vertiginosamente". A reportagem foi assinada pelo jornalista Sérgio Martins: "A ética do trabalho desses artistas é surpreendente. Eles são profissionais exigentes e disciplinados. Pode-se gostar ou não das músicas, mas não há porquê ignorar o fenômeno sertanejo". Fonte: Revista Veja: O Brasil virou sertão, p.11, 30/01/2013. Foto: capa da revista Veja - 30 de janeiro de 2013. 


\section{"Estamos aí e vamos fazer história!"}

Em 2015, Fernando Fakri de Assis mostrou que não estava de brincadeira para o lado das Organizações Globo ${ }^{257}$. Se Leonardo Chaves quer ser lembrado, no futuro, mais por sua atuação empresarial do que musical, o concorrente insiste que seu nome fique registrado na história da música sertaneja. Sorocaba deu as costas para Som Livre, em novembro de 2014, e, em menos de um ano, mostrou que veio à tona para comandar os novos rumos do gênero sertanejo no mercado fonográfico brasileiro. Eis que o primeiro episódio aconteceu em 2015. Em primeira mão, Fernando Zor ${ }^{258}$ e Sorocaba fizeram o lançamento do chamado cine-show projeto inédito que reúne cinema e show musical em uma mesma apresentação. Na préestreia $^{259}$ de Anjo de Cabelos Longos, o empresário caubói não conteve a empolgação: "Está tudo amarrado, pois das histórias das músicas vêm à história de amor que se desenrola com o filme. É um cruzamento de uma história de amor com um DVD convencional de música. Nós inventamos a palavra cine-show"260. O que Sorocaba quis dizer com isso? Que as composições escritas por ele inspirou a contextualização do enredo cinematográfico. Mas, na prática, o telespectador tem a percepção inversa: para cada cena reproduzida no filme, há uma música de pano de fundo no cenário do show. Na entrevista para a revista Billboard, Sorocaba contradiz sua declaração anterior: "O Bruno Caliman escreveu o roteiro do filme e aí começamos a escolher as músicas e também compor algumas canções. O processo foi um pouco diferente dos outros trabalhos. Algumas músicas foram feitas para esse projeto e com um tema estabelecido, pois as canções ajudam a contar uma história"261. Sorocaba sabe diferençar o público-leitor da Quem (revista de entretenimento) com o da Billboard (destinada à crítica musical internacional). Nota-se que o irmão caçula de Victor repetiu essa mesma

\footnotetext{
${ }^{257}$ Em 2014, as Organizações Globo adotaram uma nova marca: Grupo Globo. O presidente da instituição, Roberto Irineu Marinho, disse que o objetivo é reforçar a identidade das empresas ligadas à família. Atualmente, a marca reúne Infoglobo, TV Globo, GLOBOSAT, Globo.com, Sistema Globo de Rádio, Editora Globo, Som Livre, Globo Internacional e Zap. Fonte: Jornal $O$ Globo: Organizações Globo adotam uma nova marca: Grupo Globo, 27/08/2014.

${ }^{258}$ Desde 2014, Fernando Zorzanello tem adotado o sufixo “Zor” em seu sobrenome.

${ }^{259}$ A pré-estreia do filme aconteceu no dia 04 de novembro de 2015, no Shopping Pátio Paulista, em São Paulo. Depois, foram exibidas três sessões: 13 de novembro, às $21 \mathrm{~h} ; 15$ de novembro, às $19 \mathrm{~h}$; e 20 de novembro, às 21h. Nesses três dias de apresentações, a venda de ingressos estava esgotada. Fonte: site oficial de Fernando e Sorocaba.

${ }^{260}$ Revista Quem/Globo: Fernando e Sorocaba lançam projeto que mistura cinema e show: "Vamos fazer história!", 05/11/2015.

${ }^{261}$ Revista Billboard: Fernando e Sorocaba levam a música sertaneja para as telonas, 16/11/2015.
} 
fórmula na entrevista dada à Forbes. Pelo visto, os novos músicos sertanejos da geração empreendedora gostam de impressionar os profissionais da imprensa, ainda que seja à custa de contradição em face ao próprio público-consumidor. No entanto, em poucas palavras, foi o parceiro-funcionário de Sorocaba, o músico Fernando Zorzanello que abriu o jogo: “O roteiro é voltado para o show. Tudo acontece por causa do show em si”.

O cine-show foi gravado em dois planos e os sertanejos não contracenaram com os atores do elenco. A gravação do show foi feita em um estúdio intimista e confortável no estilo lounge, e contou com a presença de poucos figurantes na plateia: "O filme foi feito para não atuarmos, mas depois ficamos com vontade. Quem sabe na próxima oportunidade? Porque vai ter sequência, independe do sucesso. Vai abrir a porta para muita coisa legal. Estamos aí e vamos fazer história" ${ }^{262}$. É evidente que Sorocaba tem planos maiores do que esse. Não é à toa que ele promete um novo cine-show "independente do sucesso" da crítica especializada ou de bilheteria, porque esse projeto "vai abrir a porta para muita coisa legal". Sorocaba quer fazer história sim, mas fora das telonas do cinema. Se o empreendimento do cine-show tiver bom êxito, no futuro, ele teria o benefício exclusivo sobre o projeto. Em hipótese, poderia oferecê-lo e até impô-lo à indústria fonográfica como o sucessor do tradicional formato do DVD ao vivo. Depois da crise discófila dos anos 2000, os escritórios tiveram que promover notáveis rearranjos institucionais para conservar o controle do mercado musical. Se a vendagem de CD's deixou de ceder cifras lucrativas, o formato de gravação acústica (DVD ao vivo) abriu margem à venda de milhares de ingressos, lotando estádios espalhados pelo Brasil. Então, qual seria a estratégia de Sorocaba? Transferir esse vultoso público dos shows sertanejos às confortáveis salas de cinema. Mas, por hora, em uma tentativa de afastar o alarde prévio dos concorrentes, o músico paulista tem sido modesto na publicidade do projeto. Para eles, o cine-show é só mais uma engenhoca de mercado surgida da mente criativa de Sorocaba. Hoje, o maior trunfo para o sucesso do empresário sertanejo é a inovação tecnológica. E dessa vez, o show não seria diferente: os investimentos técnicos e artísticos, vistos nos palcos, foram transferidos para o filme: "De forma geral, ficou bem conciso e conceitual. O público não vai ouvir a gente como está acostumado a ouvir, pois é um projeto paralelo ao que estamos acostumados a fazer. Estou com um frio na barriga do caramba! Mas tenho certeza que vai mexer com a galera" ${ }^{\text {263 }}$.

\footnotetext{
${ }^{262}$ Revista Quem/Globo, 05/11/2015.

${ }^{263}$ Idem, 05/11/2015.
} 
O filme foi estrelado por Luiza Tomé, Bia Arantes, Jonatas Faro e Rodrigo Simas atores do novo time de elenco da Rede Globo ${ }^{264}$. A FS Produções Artísticas definiu que Anjo de Cabelos Longos $^{265}$ seria protagonizado pela atriz e cantora Sophia Abrahão ${ }^{266}$, funcionária recém-contratada pelo escritório de Sorocaba. O show sertanejo contou com a participação de Rio Negro e Solimões ${ }^{267}$, em $O$ Som do Silêncio, e do cantor Felipe Duran ${ }^{268}$, em E.T. A direção do longa-metragem foi assinada por Fernando "Catatau” Trevisan. O nome de Catatau é figurinha carimbada na música sertaneja. O diretor artístico é também o responsável pela gravação do DVD Irmãos, de Victor e Leo $^{269}$. O roteiro de Anjo de Cabelos Longos foi feito sob encomenda por Sorocaba ao compositor baiano Bruno Caliman. Se na agenda fonográfica, esses nomes têm status de protagonistas, fora do ramo da música, eles são meros desconhecidos por muitos. É no bastidor da música sertaneja, longe dos olhos do público ou da imprensa, que figuras importantes como Catatau e Caliman atuam. E não por acaso: os artistas mantêm uma agenda superlotada de shows pelo Brasil afora. São esses personagens que trabalham nas coxias do mercado musical e, assim, asseguram o sucesso dos sertanejos dentro dos palcos. Nos últimos anos, Bruno Caliman foi o autor de dezenas de canções que foram gravadas e popularizadas nas vozes de outros cantores do gênero: Bruno e Marrone ${ }^{270}$, Luan Santana $^{271}$, Marcos e Belutti ${ }^{272}$, Munhoz e Mariano ${ }^{273}$ e Fernando e Sorocaba ${ }^{274}$.

\footnotetext{
${ }^{264}$ Exceto a veterana atriz Luiza Tomé que, em 2006, deixou a Rede Globo pela Record.

265 "Questionado sobre quem seria seu anjo de cabelos longos da vida real, Sorocaba chegou a brincar: 'A gente prefere que seja Sophia Abrahão, mas pode o Rodrigo Simas', disse ele, referindo-se aos cabelos mais compridos do ator para a saudosa novela Boogie Oogie". Fonte: Idem, 2015.
}
${ }^{266}$ Sophia Abrahão fez sua estreia na TV em Malhação (Rede Globo). Depois, na emissora de Edir Macedo, protagonizou a novela teen, Rebeldes. Em 2013, voltou a Globo no horário nobre. Desde 2015, mantém contrato com o escritório de Sorocaba, a FS Produções Artísticas. Fonte: Ego/Globo: Sophia Abrahão assina contrato com escritório de Fernando e Sorocaba, 16/06/2015.

\footnotetext{
${ }^{267}$ Não por acaso, Fernando Zorzanello é o produtor musical dos dois.

${ }^{268}$ Fernando e Sorocaba apadrinharam a carreira de Felipe Duran. Nos capítulos 4 e 5, trago outras informações sobre esse tipo de parceria existente na música sertaneja.

${ }^{269}$ Universo Sertanejo: "Irmãos" Victor e Leo gravam DVD em São Paulo nos dias 28 e 29 de janeiro; haverá promoções para ingressos, 06/01/2015.

${ }^{270}$ Já não sei mais nada.

${ }^{271}$ Sogrão Caprichou, Te Esperando e Escreve Aí.

${ }^{272}$ Poeira da Lua e Domingo de Manhã - música mais tocada nas rádios brasileiras em 2014.

${ }^{273}$ Camaro Amarelo - música do ano de 2012 no Domingão do Faustão.

${ }^{274}$ Mármore e Gaveta.
} 
Ter repertório exclusivo é a regra de ouro para o êxito na carreira desses músicos. Contudo, em um mercado volátil como esse, são raros os exemplos de duplas sertanejas que produzem composições estritamente autorais. Victor e Leo e Fernando e Sorocaba fazem parte deste seleto time e, por isso, foram escolhidos para compor este trabalho. Nos outros casos, é corriqueiro que um único autor seja o dono de dezenas de canções consagradas nas vozes de outros intérpretes. Bruno Caliman, por exemplo, é o compositor de nove entre dez hits sertanejos ${ }^{275}$. Caliman oferta também composições para artistas de outros estilos musicais, como o axé music, pagode, forró e samba ${ }^{276}$. Por fim, há uma terceira atividade, adotada na atualidade, chamada de autoria compartilhada. A canção Gaveta ${ }^{277}$ exemplifica $^{2}$ essa prática de parceria existente entre os músicos sertanejos. Em 2013, o fonograma foi registrado no $\mathrm{ECAD}^{278}$ como propriedade autoral tanto de Sorocaba quanto de Bruno Caliman. Portanto, os dois compositores têm direitos legais sobre a obra. Mas, na prática, é quase impossível definir se houve efetivamente uma associação artística entre os dois para composição da música. Hoje, não são raros os episódios de compositores desconhecidos que escrevem sob encomenda faixas e até álbuns completos para um cantor consagrado. Às vezes, o autor não recebe o valor negociado com o cliente e o impasse vai parar na justiça. Foi o que aconteceu, em 2015, com os cantores Leonardo e Eduardo Costa. Eles foram acusados, pelo compositor Sergio Pinheiro, de plágio pelo projeto Cabaré2 $e^{279}$. Serginho, como é conhecido no meio sertanejo, é o autor de mais de 700 músicas que foram gravadas e vendidas para artistas como Leonardo, Zezé Di Camargo e Luciano, Bruno e Marrone, entre outros ${ }^{280}$. Sem dúvida alguma, a música sertaneja movimenta um comércio lucrativo de compra e venda de composições. São autores anônimos como Bruno Caliman e Sergio Pinheiro que conservam a economia deste mercado cultural ${ }^{281}$.

\footnotetext{
${ }^{275}$ Portal R7: Compositor de nove entre dez hits sertanejos dá a fórmula do sucesso: "Tem que ter sinceridade", 05/07/2013.

${ }^{276}$ Babado Novo e Asa de Águia; Inimigos da HP e Raça Negra; Aviões do Forro; Alcione.

${ }^{277}$ CD: Sinta Essa Experiência, 2013 (Som Livre).

${ }^{278}$ Escritório Central de Arrecadação e Distribuição.

${ }^{279}$ TV UOL: Cantor Leonardo é processado por plágio, 17/12/2015.

${ }^{280}$ TV Foco: Cantor Leonardo é processado por plágio com Eduardo Costa, 17/12/2015.

${ }^{281}$ Segundo Pierre Bourdieu, um bem simbólico se configura quando a um objeto artístico ou cultural é atribuído valor mercantil, sendo consagrado pelas leis do mercado ao status de mercadoria. Para esses objetos é formado um grupo consumidor, bem como de produtores de bens simbólicos (In: A Economia das Trocas Simbólicas, 2007).
} 
Dito isso, o que motivou Fernando Fakri de Assis a escolher um compositor de músicas sertanejas para ser o autor de Anjo de Cabelos Longos, se o empresário poderia ter contratado em seu lugar um roteirista profissional para escrever o longa-metragem? O jornalista Felipe Branco Cruz dá uma intrigante pista: "O roteiro do cine-show tem assinatura de Bruno Caliman que, ao lado do próprio Sorocaba, está se transformando em um dos maiores arrecadadores de direitos autorais do Brasil por causa de suas composições na música sertaneja"282. Vale lembrar que, desde 2007, Victor é o maior rival de Sorocaba na corrida pela liderança do mercado de arrecadação de direitos autorais. Bruno Caliman é um nome recente a estrear nessa lista, mas, nem por isso, o sucesso do compositor sertanejo deixa de ser pouco ameaçador ao reinado de Sorocaba. Então, por que dessa vez, ele convidaria um adversário para participar de um projeto tão ambicioso quanto esse? Sorocaba não deu uma resposta muito consistente sobre a decisão: “A ideia do projeto é minha, mas o Bruno foi um dos criadores da história. Tenho orgulho dele. É um grande compositor" ${ }^{283}$. No entanto, até o título do filme foi emprestado de uma das músicas assinadas por Bruno Caliman que é, aliás, o autor do roteiro e o responsável por outras cinco composições produzidas para a trama ${ }^{284}$. $\mathrm{Na}$ entrevista, o artista rasga elogios à atuação do compositor baiano como roteirista, mas "o Bruno foi um dos criadores da história", sendo assim, ele não foi o único autor do filme, embora Sorocaba não dê créditos para os outros nomes. E mais: define-se como mentor exclusivo do cine-show: "a ideia do projeto é minha". Seja como for, a obra foi idealizada por Sorocaba e o roteirista cumpriu com êxito a encomenda feita pelo cliente. Na pré-estreia do filme, foi dito que Anjo de Cabelos Longos seria uma biografia da dupla sertaneja Fernando e Sorocaba ${ }^{285}$. Mas, essa suposta "biografia" só teria sentido se fosse fictícia, visto que a história social dos músicos não tem conexão alguma com a trama exibida nos cinemas. No máximo, o espectador pôde assistir a cinebiografia da marca de Fernando Fakri "Sorocaba" e não do dueto. Por isso, o estudo sobre a trajetória social das duas duplas sertanejas foi tão

\footnotetext{
${ }^{282}$ UOL Música: Fernando e Sorocaba vai lançar cine-show com Rodrigo Simas e Sophia Abrahão, 16/10/2015.

${ }^{283}$ Idem, 16/10/2015.

${ }^{284}$ Trilha sonora completa do longa-metragem: Seu Herói, E.T, Lápis de Cera, Não Me Compare com Ele, Alívio e Anjo de Cabelos Longos, de Bruno Caliman; Inverno, de Sorocaba e Dan Nascimento; Do Jeito que É, de Sorocaba; Muro de Berlin, de Caco Nogueira e Douglas Cezar; Previsão do Tempo, de Caco Nogueira; O Som do Silêncio, de Sorocaba e Pedro Viana; Sem Reação, de Sorocaba e Caco Nogueira; e Vida no Campo, de Fernando Zorzanello e Paulo Perin.
}

285 “O projeto, uma biografia da dupla sertaneja Fernando \& Sorocaba, trata-se de uma junção de DVD musical com filme”. Fonte: Revista Quem, 05/11/2015. 
fundamental a este trabalho. Sem ele, poderia reproduzir uma mera ilusão de relatos biográficos e autobiográficos dos músicos ${ }^{286}$.

No enredo, Rafael (Rodrigo Simas) é um jovem humilde que vive em Nova Esperança, no interior do Mato Grosso do Sul. Depois da morte do pai, a mãe (Luiza Tomé) vai trabalhar na lavoura da fazenda do antigo patrão do marido para prover o sustento do filho. O cenário da casa dos agregados tem um ambiente modesto e a vista do rancho é bucólica. No final da laboriosa rotina sob o cabo da enxada, a matriarca entra no quarto do filho e se aflige ao vê-lo arrumando as malas. Rafael acaricia as mãos calejadas da mãe e promete oferecê-la um destino melhor e bem-aventurado. Para isso, ele terá que sair daquele fim-de-mundo para "tentar a vida" em São Paulo. Em um primeiro momento, não é bemesclarecido para o telespectador esse tal propósito de vida do rapaz. Só depois, ele confessa ao seu "anjo de cabelos longos" que sonha em trabalhar e estudar na metrópole. A roupagem do personagem é idêntica à usada pelo cantor Sorocaba: camisa social entreaberta, calças justas, botas, cinto e fivela prateada. Para este último adereço, as câmeras deram um enfoque fabuloso, afinal, estava inscrito na presilha, a marca dos patrocinadores do filme: "Fernando e Sorocaba”. A devoção do protagonista aos sertanejos é tanta que até existia um pôster oficial dos músicos na parede do quarto. Antes de se despedir, ele põe na bagagem o tradicional chapéu no estilo caubói, enquanto a mãe "abençoa" os caminhos do filho. Depois de uma longa viagem pelas estradas intermunicipais, o precário ônibus quebra perto da entrada de São Paulo. Sem titubear, o personagem vai até à estrada atrás de uma boa alma que possa lhe oferecer uma carona. Rafael é bonito e tem pinta de bom-moço, mas nenhum condutor aceita seu aceno. Eis que sua fivela prateada com o nome de "Fernando e Sorocaba" é vista por Luiza - o anjo de cabelos longos. Logo, o automóvel modelo esportivo estaciona no acostamento e a porta traseira é aberta para que o desconhecido pegue a carona. No carro, os três amigos também estavam indo à capital, mas para um show particular de Fernando e Sorocaba, na casa do empresário. Portanto, a biografia do selo "Fernando e Sorocaba" é o fio

\footnotetext{
286 "O relato, seja ele biográfico ou autobiográfico, propõe acontecimentos que, sem terem se desenrolado sempre em sua estrita sucessão cronológica, pretendem organizar-se em sequências ordenadas segundo relações inteligíveis. É provável que esse ganho de coerência esteja na origem do interesse que os investigados têm pelo empreendimento biográfico. Essa propensão a tomar-se o ideólogo de sua própria vida, selecionando certos acontecimentos significativos e estabelecendo entre eles conexões para lhes dar coerência, conta com a cumplicidade natural do biógrafo [...] não podemos compreender uma trajetória [...] sem que tenhamos previamente construído os estados sucessivos do campo no qual ela se desenrolou e, logo, o conjunto das relações objetivas que uniram o agente considerado - pelo menos em certo número de estados pertinentes - ao conjunto dos outros agentes envolvidos no mesmo campo e confrontados com o mesmo espaço dos possíveis" (BOURDIEU, Pierre. A Ilusão Biográfica, 2006, p. 183-191).
} 
condutor que garante a narrativa amorosa: Luiza só é capaz de reconhecê-lo, porque sua fivela foi confeccionada com tal assinatura; Rafael teve apenas a oportunidade de conhecê-la, graças ao show (cena A). No enredo, a autoridade simbólica do dueto é tanta que pôde até conciliar o abismo social existente entre os dois personagens (cena B). Vejamos então os diálogos:

\section{Cena A:}

- Luiza: Gostei do cinto!

- Rafael: É! Eu ganhei quando eles fizeram um show lá na minha cidade. Gostei da sua camisa também. Eu adoro o som deles, acho muito legal.

- Luiza: Sério? Então, eu tenho uma coisa para te contar que você não vai acreditar. A gente tá indo para o show deles.

- Rafael: É verdade?

- Luiza: É, mas não é qualquer show. É um show na casa de Sorocaba. Você quer ir com a gente?

- Rafael: Se não for incomodar...

\section{Cena B:}

- Luiza: E aí me fala alguma coisa sobre você...

- Rafael: Eu sou de Nova Esperança, Mato Grosso do Sul. Moro com a minha mãe e a gente trabalha numa fazenda.

- Luiza: E o que você tá fazendo em São Paulo?

- Rafael: Eu vim estudar, trabalhar e passar um tempo na casa de uns tios.

- Luiza: Eu me formei em Direito, mas eu detesto... Os meus pais também são donos de terra.

- Rafael: A gente trabalha na terra, por isso que a gente não é dono de nada não.

- Luiza: Entendi. Meus pais queriam que eu tivesse feito veterinária, que eu morasse lá com eles. Eu sou filha única e sei lá, acho que o meu pai queria que eu tomasse conta daquilo tudo. Pelo amor de Deus! Se existe algo que eu odeio nesta vida mais do que Direito é carrapato! Para o meu pai, eu seria uma típica caipira, assim de bota, chapéu, fivela e uma graminha na boca... Ai, desculpa, Rafa! Eu não falei isso para te ofender...

- Rafael: Não, não tem nada não. Eu entendi o que você quis dizer. Eu penso assim também.

Luiza é infeliz porque não aceitou o destino social reservado por sua família de classemédia alta: a medicina veterinária. Os pais são "donos de terras" e atuam na economia do agronegócio do interior brasileiro, mas a única herdeira não quis "tomar conta daquilo tudo". No futuro, o desinteresse afetivo pela herança lhe custou a amarga experiência na área do 
Direito $^{287}$. Por sua vez, Rafael está insatisfeito com os rumos sociais do seu grupo familiar. Ele e a mãe são membros da classe proletária rural e "trabalham na terra" do patrão fazendeiro, por isso, "não são donos de nada não". São Paulo é o espaço dos possíveis ${ }^{288}$, a "terra prometida" que poderá lhe oferecer acesso às instituições de ensino superior e ao mercado de trabalho. Lá, Rafael terá a oportunidade de "vencer na vida", graças ao suporte dos tios. Se Luiza é filha de um pai proprietário de latifúndio agroexportador, a mãe de Rafael é uma mera trabalhadora rural que, por sinal, faz parte da mesma mão-de-obra empregada pelo empresário. Nas cenas iniciais do filme, Rafael promete para mãe livrá-la daquele destino ingrato e sacrificante da lavoura. Desse modo, o êxito do agronegócio na economia moderna brasileira ${ }^{289}$ está longe de oferecer melhores recursos sociais à classe trabalhadora. Nos diálogos, Luiza e Rafael reproduzem os valores materiais e culturais de seus respectivos grupos sociais. Em um episódio, o "anjo de cabelos longos" exerce o poder da violência simbólica ${ }^{290}$ sobre o rapaz: "Pelo amor de Deus! Se existe algo que eu odeio nesta vida [...] é carrapato! [...] eu seria uma típica caipira, assim de bota, chapéu, fivela e uma graminha na boca...”. Luiza não só reproduz a crença de um caipira estereotipado como também desdenha da própria indumentária vestida por Rafael. O descrédito é acompanhado por um singelo pedido de desculpa: "Eu não falei isso para te ofender...”. Embora Rafael deixe nítida sua

\footnotetext{
287 "Mas há igualmente os herdeiros, com histórias, aqueles que como Frédéric se recusam, se não a herdar, pelo menos a ser herdados pela herança. A transmissão do poder entre as gerações representa sempre um momento crítico da história das unidades domésticas. Entre outras razões, porque a relação de apropriação recíproca entre o patrimônio material, cultural, social e simbólico e os indivíduos biológicos modelados para a apropriação encontra-se provisoriamente em perigo. A tendência do patrimônio (e, por aí, de toda a estrutura social) em perseverar em seu ser apenas pode realizar-se se a herança herda o herdeiro, se por intermédio especialmente daqueles que lhes têm provisoriamente o encargo e quem deve assegurar sua sucessão, o 'morto' (ou seja, a propriedade) apossa-se do vivo (ou seja, um proprietário disposto e apto a herdar)" (BOURDIEU, Pierre. A Questão da Herança. In: As Regras da Arte, 1996, p. 25-26).
}

\begin{abstract}
288 “A relação entre as posições e as tomadas de posições não tem nada de uma relação de determinação mecânica. Entre uma e outras se interpõe, de alguma maneira, o espaço dos possíveis, ou seja, o espaço das tomadas de posições realmente efetuadas tal como ele aparece quando ele é percebido através das categorias de percepção constitutivas de certo habitus, isto é, como um espaço orientado e prenhe das tomadas de posição que aí se anunciam como potencialidades objetivas [...]" (Ibidem, 1996 p. 265).
\end{abstract}

${ }^{289}$ Em 2013, o saldo do agronegócio rendeu US\$ 82,907 bilhões à balança comercial brasileira. Fonte: CONAB / Ministério da Agricultura / Ministério do Desenvolvimento. A importância do agronegócio no Brasil: grande participação no PIB - Produto Interno Bruto (22,15\%, em 2012); cria 37\% de todos os empregos do país; responde por 39\% das exportações; saldo comercial de US\$ 79 bilhões, em 2012; Hoje, 30\% das terras brasileiras são utilizadas para agropecuária. Fonte: Portal Eco Agro: A agropecuária brasileira é um bem gigantesco, um campo cheio de oportunidades de investimento e desenvolvimento, 2014.

290 “A dominação é, em geral, não evidente, não explícita, mas sutil e violenta. Uma violência simbólica que é julgada legítima dentro de cada campo e que são inerentes ao sistema, cujas instituições e práticas revertem, inexoravelmente, os ganhos de todos os tipos de capital para os agentes dominantes. A violência simbólica, doce e mascarada, se exerce com a cumplicidade daquele que a sofre, das suas vítimas" (Idem, Razões Práticas: Sobre a Teoria da Ação, 1999, p. 275). 
expressão de constrangimento, ele dissimula um sorriso amarelo e diz: "Não, não tem nada não! Eu entendi o que você quis dizer. Eu penso assim também”. De todo modo, Luiza (Sophia Abrahão) é o papel da mocinha clássica: meiga, sonhadora e romântica que se encanta pelo jeito humilde de Rafael (Rodrigo Simas).

Dentro do automóvel, ela está na companhia de mais dois amigos rumo ao show privê sertanejo: Guilherme (Jonatas Faro), o playboy irresponsável que dirige com a carteira de habilitação vencida e põe obstáculos à aproximação do casal protagonista, e Paulinha (Bia Arantes), a patricinha moderna que tem o corte de cabelo chanel no estilo retrô, ligada no mundo da moda e popular entre os colegas. A viagem, que tinha tudo para ser tranquila, quase não termina por uma série de imprevistos. Em uma blitz pela estrada, Guilherme "quase" é multado por dirigir com a carteira de habilitação vencida. O policial (Dinho Machado), um contador de piada sem graça, é também "pouco honesto" no trabalho. O rapaz tenta até suborná-lo com dinheiro, porém, o guarda interesseiro faz outra oferta: nada de multa, mas em troca (extorsão), ele quer um convite VIP para o show particular de Fernando e Sorocaba e de quebra uma carona (propina). É inegável que a cena faz apologia à prática de corrupção voluntária de uma autoridade policial. Certamente, a equipe de Sorocaba não se dispôs a revisar o roteiro ou simplesmente foi feito pouco-caso sobre o tema de contravenção penal, um assunto tão discutível na sociedade brasileira ${ }^{291}$. Paulinha tomou o assento do motorista e prosseguiu a excursão sertaneja. No meio da estrada, a gasolina do carro acaba e não existia nenhum posto à vista. Nessa hora, Guilherme quis pôr Rafael em seu devido lugar: "Vai lá pegar". Luiza se revolta, chama o amigo de grosseiro e resolve ir atrás do mato-grossense do sul. No caminho até o posto, inicia-se a história de amor vivida pelos pombinhos apaixonados. Por fim, eles resolvem parar em uma lanchonete à beira da estrada. Na saída, foram surpreendidos por um assaltante, que usou Luiza como refém para saquear o caixa do estabelecimento e roubar os clientes. Sem pensar duas vezes, Rafael entra em luta corporal com o bandido e acaba sendo baleado no ventre. Em estado de choque, estirado sobre o chão, ele entra em uma espécie de devaneio: se vê deitado ao lado de Luiza, segurando uma menina nos braços e pensa: "É como o meu pai costumava dizer: tudo de alguma forma está escrito. Tudo o que tem que acontecer vai acontecer. E, durante o caminho, a gente só precisa encontrar o nosso anjo e ser o anjo de alguém". Mas, o herói saiu ileso graças à fivela prateada do cinto "Fernando e Sorocaba". Depois de tantos contratempos, os cinco personagens chegam até a apresentação dos sertanejos. A música ao vivo embala o clima

\footnotetext{
${ }^{291}$ Revista Veja: Polícia Militar do Rio é a campeã de corrução no Brasil, 08/04/2013.
} 
romântico do primeiro beijo do casal. Pronto! Ficção e show formaram uma combinação perfeita - pelos menos, nas telonas.

Na história, os personagens de Luiza, Guilherme e Paulinha são brancos, escolarizados e filhos da classe-média alta brasileira; em contrapartida, Rafael tem pouca escolaridade, nenhuma qualificação profissional e é integrante de uma família desprovida de recursos econômicos. Todos os anos, ele e centenas de outros jovens migrantes saem desamparados de suas cidades-natais e chegam às grandes capitais atrás da promessa de um futuro melhor. Então, o que reúne esses quatro personagens em um mesmo enredo? O "amor pela arte" de Fernando e Sorocaba? Mas não foi dito que o filme seria uma biografia da dupla sertaneja ? $^{292} \mathrm{Na}$ realidade, a biografia construída no enredo é sobre o público de Fernando e Sorocaba e não sobre eles em si. Como assim? Voltemos à narrativa fílmica: Luiza será a herdeira do pai fazendeiro, ao passo que Rafael é filho de uma humilde trabalhadora rural. Então, tanto ela quanto os amigos mantêm uma posição social completamente contrária à ocupada por Rafael. Só que, na ficção, isso não é um impedimento para que eles se envolvam afetivamente. A "história de amor" vivida pelo casal só pôde ser concebida graças ao "amor pela arte" de Fernando e Sorocaba, tanto partilhado entre os dois - aliás, a única afinidade em comum existente ali. Não nos esquecemos de que "Sorocaba" é um personagem artístico criado pela mente inteligente de Fernando Fakri de Assis. O empresário sertanejo conhece o público que acompanha "Sorocaba" e, por isso, o filme foi pensado para conciliar o ouvinte tradicional (Rafael) e a nova audiência (Luiza e os amigos). Depois de ter deixado o escritório Som Livre (2014), esse tem sido seu maior intuito empresarial: reunir duas classes sociais em uma mesma apresentação. Se a classe-trabalhadora vai aos shows, porque não convidar essa classe-média alta para assistir aos espetáculos também, só que em uma confortável sala de cinema? Voltemos novamente à história:

- Rafael: Eu ganhei [o cinto] quando eles fizeram um show lá na minha cidade [...] Eu adoro o som deles, acho muito legal.

- Luiza: Então, eu tenho uma coisa para te contar que você não vai acreditar. A gente tá indo para o show deles [...] mas não é qualquer show. É um show na casa de Sorocaba. Você quer ir com a gente?

Rafael apenas esteve em um show da dupla em Nova Esperança (Mato Grosso do Sul); Luiza está a caminho de assisti-los, "mas não é qualquer show: é um show na casa de Sorocaba". Ela ainda faz um convite especial: "Você quer ir com a gente?". O conceito 
fundamental do ambicioso formato cine-show é este: "convidar" o público-consumidor jovem e urbano desses dois estratos sociais às salas dos cinemas e, assim, conciliá-los em um mesmo produto audiovisual. Luiza (Sophia Abrahão) reproduz na arte a própria posição social ocupada por Sorocaba: Fernando Fakri de Assis é filho de uma família bem-sucedida do agronegócio brasileiro e, na ficção, ela simboliza essa mesma fração de classe social do artista. Vale a pena repetir que o êxito na economia do agrobusiness tem sido o maior responsável pela promoção dos lucros extraordinários obtidos pelos novos artistas sertanejos $^{293}$. Se Luiza não quis ser herdada pela herança ${ }^{294}$, o paulista aceitou herdar o patrimônio econômico da família para investi-lo no show business da música sertaneja. Hoje, Sorocaba tem em mãos a receita indispensável para o sucesso artístico, o uso tecnológico: "Nós estamos sempre em busca de novas tecnologias e formatos. Pensando nisso, criamos o conceito cine-show para o nosso DVD. Trata-se de um filme longa-metragem com momentos musicais intercalados com a trama" ${ }^{, 295}$. Sorocaba não se refere à dupla ou a Fernando ao dizer "nós", mas sobre a marca empresarial "Fernando e Sorocaba" - selo no qual ele é o único dono. Em suas palavras, o conceito do cine-show não seria nem de um filme nem de um DVD de show e sim uma fusão entre ficção e musical ${ }^{296}$.

O artista é popular por trazer aos palcos um arsenal completo de novas engenhocas tecnológicas, destinadas a levar entretenimento e diversão à plateia da balada sertaneja. Porém, o que Sorocaba quis se referir com "novos formatos"? Para o jornalista Felipe Branco Cruz, ele abre o jogo ${ }^{297}$ : "O formato de DVD sertanejo ao vivo está desgastado. Agora, esperamos renovar a maneira como as pessoas ouvem música sertaneja. O objetivo não é exibir nos cinemas, mas estamos pensando em fazer algumas projeções em cidades menores, como um cinema itinerante. Ninguém aguenta mais ver o DVD ao vivo de sertanejo com painelzão de LED atrás. Queremos renovar o formato e abrir novos horizontes". Então, o

\footnotetext{
293 “O agronegócio é o principal provedor econômico da música sertaneja [...] Esse circuito gira muito dinheiro. O que consegue manter esse gênero ascendente é vitamina - vitamina ali é dinheiro. Os shows e eventos de agronegócios são as molas propulsoras do sucesso financeiro destes novos artistas sertanejos", Prof. Ivan Vilela. Fonte: do autor (2014).

${ }^{294}$ Ibidem, 1996, p. 25-26.

${ }^{295}$ Site oficial de Fernando e Sorocaba.

${ }^{296}$ Rodrigo Amaral da Rocha: [O formato] teve inspiração em produções internacionais, como The Wall do Pink Floyd e The Songs Remains The Same do Led Zeppelin? Sorocaba: Tudo o que a vê e ouve serve de inspiração. Queremos sempre o melhor para o nosso público. Fonte: Revista Billboard, 2015.

${ }^{297}$ UOL Música, 2015.
} 
filme foi apenas a fachada do negócio? Sim. Para o empresário, o alvo não foi o cine-show em si, mas estabelecer um novo formato comercial à música sertaneja. Na atualidade, a gravação do DVD ao vivo é o grande carro-chefe do gênero. O sucesso do movimento universitário no ano de 2005 contribuiu para popularizar esse modelo de show-acústico. O sucesso de Fernando e Sorocaba veio nessa mesma esteira e, até hoje, o duo sertanejo tem se beneficiado desse molde artístico. Então, por que só agora “o formato de DVD ao vivo está desgastado"? Simples. Nesse meio tempo, ele abriu seu próprio escritório ${ }^{298}$ e pôde agenciar a carreira da dupla fora das rédeas do selo Som Livre (Organizações Globo). Essa autonomia lhe rendeu boas oportunidades no ramo do empreendedorismo artístico. Sorocaba, por exemplo, é sócio da franquia Wood's ${ }^{299}$, empresa especializada em baladas sertanejas com 16 sedes espalhadas pelo país e com um faturamento anual de $\mathrm{R} \$ 100$ milhões $^{300}$. Nos últimos dois anos, o êxito logrado pelo escritório particular do sertanejo (FS Produções Artísticas) tem dado dor de cabeça aos concorrentes das gravadoras multinacionais. Por hora, o sucesso de Sorocaba rumo à liderança do gênero sertanejo tem posto em xeque a hegemonia do mercado fonográfico brasileiro. Portanto, ele promete que irá "renovar a maneira como as pessoas ouvem música sertaneja" e que o formato do cine-show poderá "abrir novos horizontes" nessa corrida institucional, pois "ninguém aguenta mais ver o DVD ao vivo de sertanejo com painelzão de LED atrás". No entanto, por que Sorocaba menospreza tanto os monitores digitais de alta qualidade em 3D, se ele usa e abusa dessa mesma fórmula em uma única apresentação? Por enquanto, é esse o formato aceito como legítimo pelo mercado da música sertaneja. Sem o DVD acústico, a carreira artística de Sorocaba não poderia ter ir ido tão longe assim. Mas hoje, o empresário paulista só terá a chance de impor um novo formato se antes for capaz de desvalidar o modelo de gravação tradicional. Não é à toa que as empresas ligadas ao Grupo Globo estão empurrando Leonardo Chaves nessa mesma direção. De dois anos para cá, a disputa artística entre Victor e Leo (Som Livre) e Fernando e Sorocaba (FS Produções Artísticas) está se tornando também institucional. Hoje, Leo e Sorocaba são experientes nomes do sertanejo empreendedor. Para eles, a "universidade" já foi concluída e com "êxito".

\footnotetext{
298 "Faz toda a diferença ter um escritório com estrutura bacana, ter um estúdio e uma gravadora própria! Assim, conseguimos cuidar de perto de todos os processos". Fonte: Billboard: Fernando e Sorocaba levam a música sertaneja para as telonas, 16 de novembro de 2015.

299 "Para Charles Bonissoni, um dos sócios e criadores da rede de baladas Wood's, a receita do sucesso está na explosão do sertanejo universitário no país, que fez com que artistas de renome vissem a Wood's como a referência no gênero. Hoje, diversos artistas como Sorocaba, Cristiano Araújo, Marrone e Michel Teló compraram a ideia e se tornaram sócios das casas em diversos locais pelo país". Fonte: Jornal Gazeta do Povo, $13 / 12 / 2014$
}

${ }^{300}$ Jornal Gazeta do Povo: Wood's chega aos R\$ 100 milhões, 13/12/2014. 

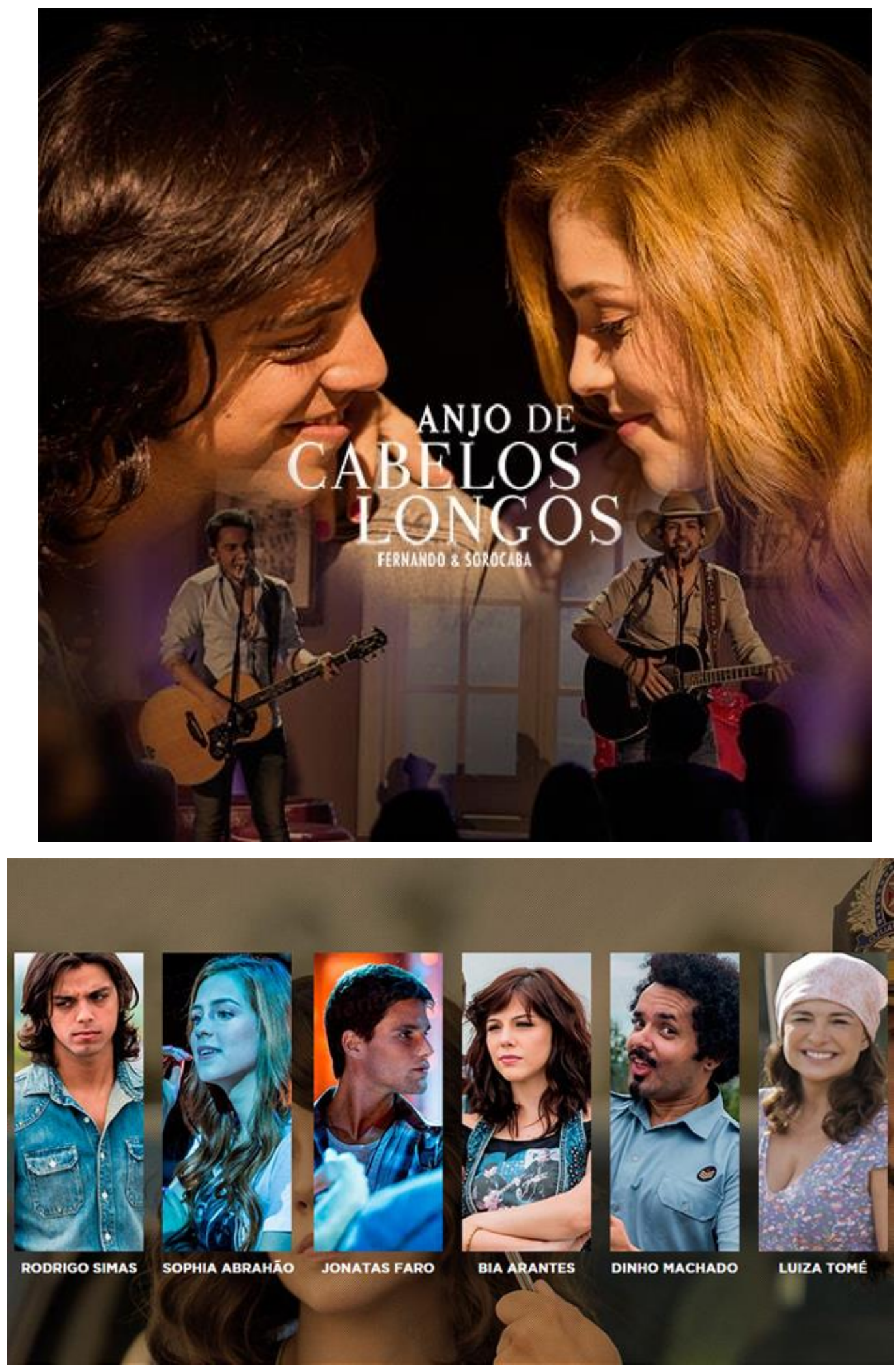

Divulgação oficial da capa (acima) e contracapa (abaixo) de Anjo de Cabelos Longos (2015). O formato foi batizado com o nome de cine-show (fusão de DVD musical e filme). Em nove anos de estrada, esse é o projeto mais audacioso de Fernando e Sorocaba. O longa-metragem foi gravado nos dias 19 e 20 de agosto de 2014, no Hangar Studios, em São Paulo, e apresentado ao público entre os dias 13 e 15 de novembro de 2014, no Shopping Pátio Paulista. O intuito do filme é convidar tanto os estratos populares da classe-média emergente Rafael (Rodrigo Simas), a mãe (Luiza Tomé) e o policial (Dinho Machado) -, quanto os jovens urbanos da classe-média alta - Luiza (Sophia Abrahão), Guilherme (Jonatas Faro) e Paulinha (Bia Arantes) - às plateias dos cinemas. Foto: divulgação. 


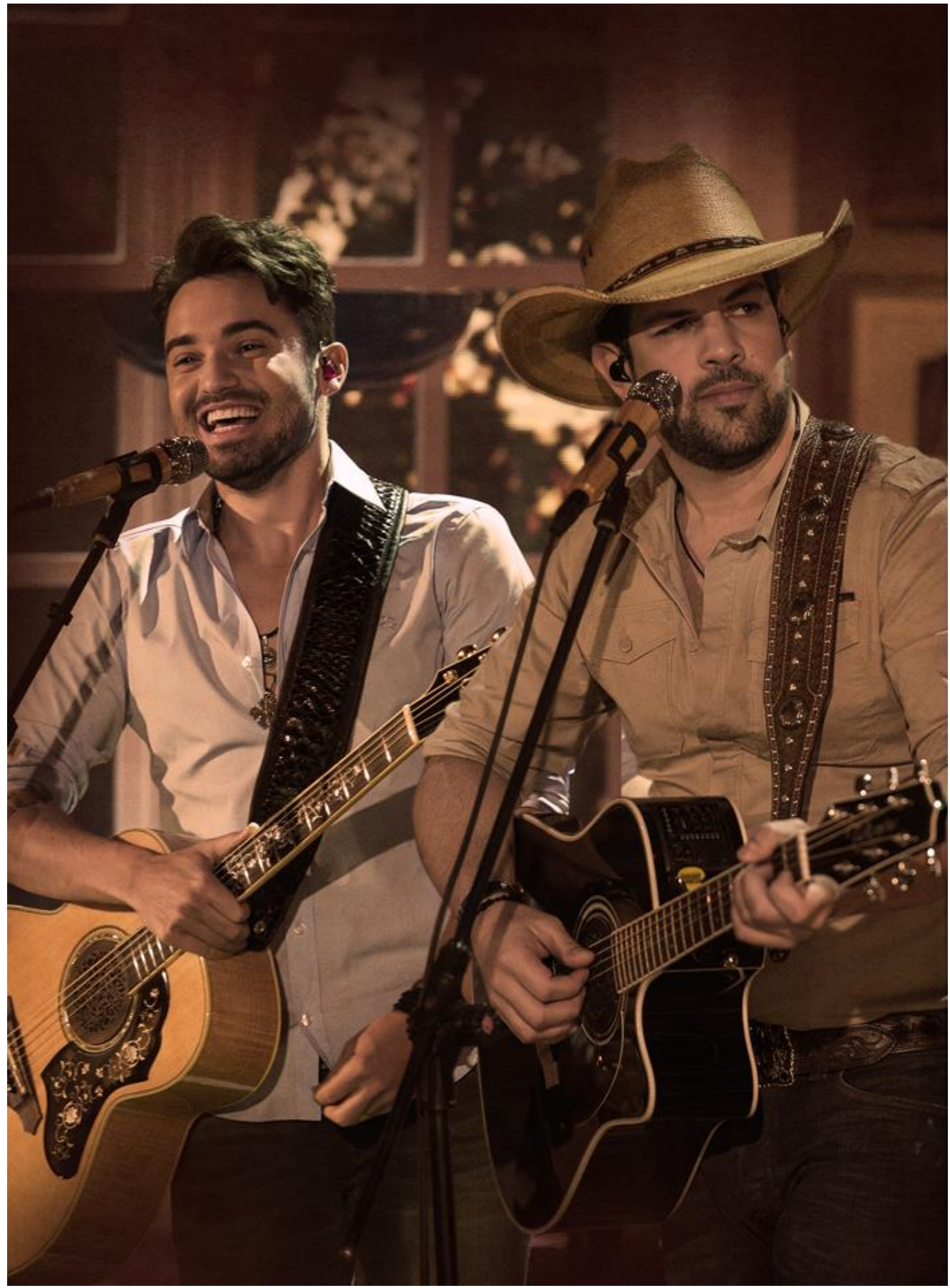

Fernando Zorzanello (à esquerda) e Sorocaba (à direita) no estúdio de filmagem do DVD acústico. Foto: Cadu Fernandes. A gravação do show foi feita em um espaço intimista e na presença de uma pequena plateia figurante. Esse mesmo molde foi adotado por Victor e Leo para o DVD Irmãos (2015). Na década de 1990, o projeto Acústico MTV marcou a trajetória da emissora no Brasil. Na música sertaneja, somente Chrystian e Ralf (1998) e Bruno e Marrone (2001) gravaram nesse formato. Nos anos 2000, a gravação acústica virou febre entre os sertanejos universitários. Hoje, Sorocaba quer inová-lo: "Estou muito feliz com esse projeto. Os nossos fãs estavam muito ansiosos para lançarmos. Gravamos ano passado, mais de um ano para lançar. Levou o tempo de uma produção cinematográfica mesmo. Não tínhamos ideia do resultado final, mas ficou maravilhoso. A ideia era renovar a maneira como as pessoas ouvem música sertaneja e abrir novos horizontes"301. Em 2016, o cine-show rendeu um disco de platina a Fernando e Sorocaba. Em dois meses, o DVD Anjo de Cabelos Longos atingiu a marca de 80 mil unidades vendidas ${ }^{302}$.

${ }^{301}$ Revista Billboard: Fernando e Sorocaba ganham disco de platina, 10 de janeiro de 2016.

${ }^{302}$ Portal Ego/Globo: Fernando e Sorocaba lançam projeto que une DVD musical com filme, 26/10/2015. 


\section{A reinvenção do sertão brasileiro no novo cancioneiro sertanejo}

Saia desse asfalto e vem pra nossa estrada que é de chão

Tem poeira e barro, tem cavalo e boi, preste atenção

Você não vai se arrepender

Pois a paisagem pode crer

É demais, é de babar...

Descalço, sem se preocupar

Se solte e venha para o sertão

O céu no chão parece estar

Sem trânsito, sem avião ${ }^{303}$.

Usa e abusa, faz o que quiser de mim

Pode me ligar quando tiver a fim

Não demora amor, não sabe o que cê tá perdendo

Pode vir com tudo que hoje eu tô um veneno

Veneno, veneno, veneno, veneno Pode vir com tudo que hoje eu tô um veneno

Não me provoca, cê não sabe o perigo que eu sou Eu sou, sou perito na arte de fazer amor Duvida, vai queimar sua língua, não sabe o que diz Não espera, vem pagar pra ver que eu te faço feliz

Sou do tipo de pessoa Que faz e não fala, que não perde tempo

Vem ni mim, tô facin Hoje eu tô um veneno ${ }^{304}$.

\footnotetext{
${ }^{303}$ Victor e Leo: Sem Trânsito, Sem Avião, 2008 - álbum: Borboletas. Composição: Victor Chaves.

${ }^{304}$ Fernando e Sorocaba: Veneno, 2013 - álbum: Homens e Anjos. Composição: Sorocaba/Caco Nogueira/Thiago Servo.
} 
Victor e Leo e Fernando e Sorocaba são artistas que têm um repertório musical estritamente autoral. Ter esse capital artístico em mãos foi fundamental à construção de uma carreira autônoma, pois é um componente diferenciador dentro do mercado sertanejo. Desde 2008, Victor Chaves e Fernando Fakri de Assis "Sorocaba" reúnem centenas de fonogramas registrados no ECAD. Os dois compositores sertanejos têm ocupado a liderança na arrecadação e distribuição de direitos autorais em todos os segmentos e gêneros musicais brasileiros - à frente até mesmo de Roberto Carlos. No auge do movimento universitário, o ineditismo autoral estava longe de ser uma regra consensual dos novos artistas. Essa prática incomodou os ícones do sertanejo romântico dos anos 1990. Zezé Di Camargo foi um dos maiores porta-vozes críticos dessa tendência:

A moda naquele momento era pegar canções clássicas, tocar de forma acelerada, mudar um pouquinho o gênero e requentar músicas dos anos 1990. No começo, existiu uma enorme rivalidade entre o sertanejo romântico e os músicos universitários. Os artistas mais antigos se incomodaram, afinal, depois de duas décadas surgiria uma nova geração que estava tomando conta do mercado, deixando um pouco de escanteio outras duplas consagradas. $\mathrm{O}$ mercado quer novidade e houve uma explosão de duplas novas. O Zezé Di Camargo já explicou essa indisposição, e ele tem algum razão nisso. Na verdade, os caras não estavam fazendo nada novo, a não ser uma roupagem do que eles tinham feito lá atrás. Ele cita muito Menina Veneno, que ele gravou em 1996 e é um baita de um pop. Dez anos depois, os novatos falavam que estavam fazendo roupagem pop ou nova, mas quem fez isso foi o Zezé lá atrás. Tinha disso, certo incômodo de ver uma galera nova dominar o mercado, e também pela postura destes novos músicos em divulgarem uma música falsamente original, que na verdade já era algo requentado e não tinha genialidade alguma. Victor e Leo e Fernando e Sorocaba nunca fizeram isso. As músicas deles eram próprias, inéditas e com outras influências ${ }^{305}$.

Não é mera casualidade que Victor Chaves autovalorize tanto a originalidade de suas composições ou que Sorocaba edifique tanto sua posição de artista inovador e diferenciado. Ter um repertório exclusivo e inédito em um mercado competitivo como é a música sertaneja foi condição decisiva à consolidação e à manutenção comercial. Mas, o trabalho autoral não atuou sozinho na promoção da carreira musical de Victor e Leo e Fernando e Sorocaba. Cada qual soube personificar um estilo artístico que atendesse a um perfil de consumidor específico. Sorocaba, por exemplo, abraçou a linguagem temática do movimento universitário, que atraía o público jovem e urbano: a farra, a diversão, as festas, as baladas eletrônicas, a bebedeira e a embriaguez, e os romances casuais, sem abrir mão do universo romântico apreciado pelos ouvintes mais tradicionais. Já as narrativas de Victor e Leo

\footnotetext{
${ }^{305}$ Entrevista de André Piunti ao autor, 28 de novembro de 2014.
} 
seguiram em uma esteira oposta: eles trouxeram o ambiente bucólico do sertão, a rotina rural do sertanista e a figura simples do caipira. Esse tipo de cancioneiro teve bons frutos e foi bem-acolhido pelos artistas da MPB-caipira. Os enredos românticos não foram abandonados, mas reelaborados em um estilo mais lírico do que melodramático, conquistando plateias de norte a sul no Brasil. Todavia, há pouco consenso entre os novos artistas sertanejos sobre um estilo conceitual ou uma estética temática que os definam. Em sua tese de doutorado, Cowboys do Asfalto: Música Sertaneja e Modernização Brasileira, o historiador Gustavo Alonso esboçou os três principais gêneros:

São elas: (1) uma poética amorosa otimista, na qual os amantes querem efetivar seus sentimentos amorosos e o tom da canção é otimista. Trata-se da "poética do amor afirmativo"; (2) em segundo lugar estão as canções que favorecem encontros fortuitos e breves em festas. Trata-se da "poética da farra"; (3) caso não haja correspondência entre os amantes na lógica rápida dos amores furtivos, impera a lógica do "tô nem aî", ou seja, não se sofre mais por amor e parte-se para outros relacionamentos aparentemente sem culpas. Esta é a "poética do "tô nem aî"”. Somadas as três propostas, percebe-se que, ao menos tematicamente, houve uma mudança de 180 graus no sertanejo universitário. Se os sucessos de Milionário \& José Rico, Zezé Di Camargo \& Luciano, Chitãozinho \& Xororó e Leandro \& Leonardo eram basicamente canções "de corno", que cantavam a distância da pessoa amada e a impossibilidade da realização amorosa, o atual sertanejo universitário subverteu esta lógica. Hoje se busca a concretização do amor; há um hedonismo individualista que faz com que o sujeito não sofra se a relação amorosa não se concretizar ${ }^{306}$.

Essas três estéticas temáticas: (1) a poética do amor afirmativo, (2) a poética da farra, (3) a poética do "tô nem á́" e o hedonismo individualista resumem com exatidão as composições musicais de Fernando Fakri de Assis. Na epígrafe deste capítulo, a canção Veneno (2013) reúne duas poéticas construídas pelo autor, embora haja as três no repertório completo. No entanto, ao examinar a música de Victor e Leo, Sem trânsito, Sem avião (2008), nenhuma dessas três poéticas está presente, ainda que o amor afirmativo esteja presente em outras obras. Como se vê, o cancioneiro do novo sertanejo está longe de ser homogêneo, quem dera padronizado. Assim sendo, o rótulo "universitário" só poder ser lido como um índice terminológico e não como um atributo conceitual definidor da temática ou do estilo musical do gênero sertanejo: “O sufixo universitário marcou a estreia de um movimento específico na música sertaneja, mas nunca será propriamente um gênero ou estilo consensual, somente uma sacada de marketing. Hoje, chamá-los de sertanejos universitários não faz mais sentido, mas é fundamental investigar a importância dessa atualização na música sertaneja"307.

\footnotetext{
${ }^{306}$ ALONSO, Gustavo, 2011, p.439.

${ }^{307}$ Entrevista de André Piunti ao autor, 28 de novembro de 2014.
} 
Encerrada a pesquisa de campo, em janeiro de 2015, logo surgiu outra questão a ser investigada: o valor discursivo das letras das canções das duplas evidenciava uma grande assimetria estrutural entre elas. Nesse quesito, tanto a identidade musical dos retratados quanto as temáticas dos cancioneiros eram discutíveis. É claro que as atuais demandas do mercado fonográfico e os anseios da indústria fonográfica estimulam respostas artísticas heterogêneas. Isso é o esperado. Diversificar uma pequena individualidade é a regra desse negócio. Para além dessas imposições mercadológicas, este capítulo trará uma discussão comparativa das narrativas musicais de Victor e Leo e Fernando e Sorocaba, interpretando, assim, as diferentes apropriações temáticas que compõem o novo cancioneiro sertanejo.

Como proposto na introdução, apresentarei os comentários do violista e professor de música da ECA/USP, Ivan Vilela ${ }^{308}$. No decorrer das apresentações, registrei os instrumentos e também as técnicas de canto exibidas pelos dois duetos sertanejos. Em virtude do meu desconhecimento formal de cada artefato instrumental e dos tipos de timbres vocais, solicitei a contribuição do professor para elaborar uma descrição minimamente técnica. Mesmo sendo uma dissertação sociológica, o objeto de estudo é estritamente musical. Deixar de relatar o papel dos instrumentos ou das modalidades de canto seria uma dose de omissão. Todavia, reconheço que suas interpretações carreguem certo conteúdo normativo. Por isso, integro suas observações apenas como suporte descritivo, evitando tomá-las como categorias sociais analíticas.

Victor e Leo e Fernando e Sorocaba têm estilos instrumentais muito semelhantes aos vistos pelos artistas do cenário pop internacional. Exceto o uso de violão em cordas de aço, que ainda assim, concorre com dezenas de instrumentos eletrificados durante a apresentação dos modões de viola nos shows. O espetáculo cênico se diferencia entre as duplas (tema do próximo capítulo), no entanto, o que basicamente distingue a produção de um e de outro é o valor discursivo das canções ${ }^{309}$. À medida que o estudo de caso avançava, ficava claro que a competição entre os duetos não era somente comercial, mas também simbólica - uma disputa muitas vezes objetivada tanto na letra da canção quanta na identidade musical adotada dentro e fora dos palcos.

\footnotetext{
${ }^{308}$ Professor na Faculdade de Música e no Programa de Pós-Graduação da Escola de Comunicação e Artes da Universidade de São Paulo, na área de Musicologia. Atua como compositor, pesquisador, arranjador e instrumentista.

${ }^{309}$ Essa tríade de análises (discursiva/estrutural, instrumental/tímbrica e cênico/performática) foi uma sugestão do professor Marcos Napolitano. É uma espécie de "tecnização" do objeto estudado que se mostrou adequada ao problema de investigação.
} 


\title{
Victor e Leo: do sertão mineiro místico ao cenário paradisíaco carioca
}

Como sugerido, exibiremos as letras das canções produzidas por Victor e Leo. Depois, analisaremos a estrutura discursiva da canção, ou seja, como os elementos do cancioneiro são elaborados no processo de composição musical. Para tal objetivo, foram selecionadas cinco músicas (elencadas na ordem A, B, C, D, E) escritas em fases distintas da trajetória social dos irmãos sertanejos (apontando possíveis modificações temáticas). O mesmo exame será feito separadamente com Fernando e Sorocaba. Finalmente, será construído um retrato comparativo entre as duplas.

(A-) Victor \& Leo: Vida Boa, 2006 - álbum: Victor \& Leo Ao Vivo.

Composição: Victor Chaves.

\author{
Moro num lugar \\ Numa casinha inocente do sertão \\ De fogo baixo aceso no fogão \\ Fogão à lenha ai, ai \\ Tenho tudo aqui \\ Umas vaquinha leiteira \\ Um burro bão \\ Uma baixada ribeira \\ E um violão e umas galinha ai, ai \\ Tenho no quintal uns pé de fruta e de fror \\ E no meu peito por amor \\ Plantei alguém (plantei alguém) \\ Que vida boa ô ô ô \\ Que vida boa \\ Sapo caiu na lagoa \\ Sou eu no caminho do meu sertão \\ Vez e outra vou \\ $\mathrm{Na}$ venda do vilarejo pra comprar \\ Sar grosso, cravo e outras coisa que fartá \\ Marvada pinga ai, ai \\ Pego o meu burrão \\ Faço na estrada a poeira levantar \\ Qualquer tristeza que for não vai passar \\ Do mata-burro ai, ai
}


Galopando vou

Depois da curva tem alguém

Que chamo sempre de meu bem

A me esperar (a me esperar)

Que vida boa ô ô ô

Que vida boa

Sapo caiu na lagoa

Sou eu no caminho do meu sertão

No quadro Bem Sertanejo 310 , Victor Chaves declarou que: “A música que levou o grande público a conhecer a gente foi Vida Boa. Falei: 'cara, vou fazer uma música de um sapo'. Fiquei lembrando a avó contando a história da carochinha, de um sapo que caiu na lagoa e foi recebido com uma festa no céu". No estudo pioneiro sobre a cultura caipira ${ }^{311}$, Antonio Candido reservou espaço ao dialeto caipira, considerado no português formal como um "erro" pela ausência de concordâncias gramaticais. Esses "erros" são bem salientados tanto na composição de Victor quanto na pronúncia cantada por Leo: “tenho no quintal uns pé de fruta e de fror", “[...] sar grosso, cravo e outras coisa que fartá, marvada pinga" e outros sublinhados no texto. Por certo, ainda é um linguajar típico da região onde foram criados. Em 2006, Vida Boa foi a primeira canção da dupla a chamar atenção da gravadora Sony-BMG. A letra da canção tem como pano de fundo a rotina do caipira. Há inúmeros elementos do universo interiorano: a simplicidade (a casinha inocente do sertão e a venda no vilarejo); a natureza (a lagoa, o ribeirão, as árvores e os pés de frutas e de flores); os animais (o burro trabalhador, o sapo, as galinhas e a vaca leiteira); os artefatos (fogão à lenha); temperos alimentícios e bebidas (cravo, sal grosso e pinga) e, sobretudo, o uso violão, como elemento cultural e socializador. A passagem "que vida boa, sapo caiu na lagoa, sou eu assim no caminho do meu sertão" é uma metáfora do compositor para exprimir seu contentamento com tal ambiente, supostamente igual ao experimentado por um sapo ao se refrescar em uma lagoa.

Hoje, o estado de Minas Gerais é definido por um sistema latifundiário de exportação agrícola cafeeira $^{312}$, diferente do interior paulista ligado ao agronegócio de grande exportação

\footnotetext{
${ }^{310}$ Programa Fantástico (Rede Globo), exibido em 19 de outubro de 2014.

${ }^{311}$ Cf. CANDIDO, Antonio. Os Parceiros do Rio Bonito: estudo sobre o caipira paulista e a transformação dos seus meios de vida (publicado originalmente em 1964) (4ed). Livraria Duas Cidades Ltda. São Paulo. Edição. 1977.

${ }^{312}$ O setor primário da economia mineira na agricultura é formado pela produção de café, cana-de-açúcar, milho e feijão.
} 
mundial de commodities. Portanto, a fazenda mineira da cidade de Abre Campo (MG), espaço em que Victor e Leo cresceram, está longe de ser uma roça. O "sertão místico" dito pelo compositor faz parte de uma efabulação artística, não uma característica geográfica. No entanto, a letra dessa canção se aproxima mais das narrativas bucólicas dos primeiros compositores caipiras (Raul Torres, João Pacífico e Tonico e Tinoco) do que do universo temático do sertanejo moderno dos anos 1970 ou do sertanejo romântico da década de 1990. Aliás, uma música caipira construída pela elite intelectual-artística ligada à academia e à MPB e alinhada ao discurso nacional-popular dos anos 1960 e 1970, como aponta o historiador Marcos Napolitano ${ }^{313}$. Os irmãos têm buscado parcerias com o compositor Renato Teixeira, um dos maiores porta-vozes da distinção entre música sertaneja e música caipira, e Almir Sater, violista renomado. Notadamente, Vida Boa traz a valorização da tradição rural, do sertão e do caipira, em oposição às composições modernas e urbanas do movimento universitário. A canção funciona como espécie de resistência cultural ao cenário musical contemporâneo.

Vitor Chaves Zapalá Pimentel não chegou a estudar em uma universidade e isso também não faria diferença alguma: o destino social como músico foi traçado desde a infância pela família. Hoje, o compositor desenvolveu um estilo lírico tão sofisticado que o público tem que se esforçar para entendê-lo. O uso de metáforas, expressões oníricas e peças abstratas é conciliado nas canções com os elementos culturais e imaginários que compõem a sua própria história social: "água de oceano pra beber"314 "um dia seus pés vão me levar onde minhas mãos não podem chegar"315, "borboletas sempre voltam e o seu jardim sou eu"316,

\footnotetext{
313 "É neste contexto que nasce a ideia de um sertanejo puro e de um sertanejo um pouco mais voltado para o mercado, sobretudo quando se fala em mercado, nos anos 1950, é o rádio voltado para o público urbano [...]. O caipira sempre ficou com uma contribuição residual nesta ideia do imaginário nacional popular. É como se fosse uma espécie de cultura local, localizada e sem pontos de contato. Isso começa a mudar nos anos 1960 com Disparada [Geraldo Vandré], que se torna uma moda de viola e uma moda pensada no contexto da MPB - de uma música nacional popular. Nos anos 1970, é interessante que o caipira é resgatado como alternativa ao nacionalismo da esquerda. Quer dizer, o caipira acaba sendo um representante/depositário da cultura local que, nos anos 1970, é apropriado como forma alternativa de uma cultura popular crítica alternativa do nacional popular de resistência [...]. Tal crítica é iniciada pela Bossa Nova e institucionalizada pela MPB, na década de 1960. A partir daí, começa uma tensão de um sertanejo que vai se encaminhando para uma linguagem de mercado, arranjos padronizados, um gênero mais estabelecido e estruturado e até com seus clichês, e uma tentativa de manter um espaço da viola que, junto da sanfona, passa a ser o centro da música caipira”, Entrevista de Marcos Napolitano ao autor, 07 de novembro de 2014.
}

\footnotetext{
${ }^{314}$ Água de Oceano - álbum: Boa Sorte Pra Você, 2010.

${ }^{315}$ Tem que Ser Você - álbum: Ao Vivo em Uberlândia, 2007.

${ }^{316}$ Borboletas - álbum: Borboletas, 2008.
} 
"vejo minha fada e sua vara de condão tocando o meu coração"317, "maga magia de lua luz e a noite virando dia, água na boca secando na louca chuva de bruxaria, hoje você vem dizia",318, "sapo caiu na lagoa sou eu no caminho do meu sertão",319 " "trabalho cantando a terra é a inspiração, Deus e eu no sertão" ${ }^{320}$.

Ivan Vilela: Esse jeito de cantar [de Leonardo Chaves] é moderno e veio do axé e, depois, em 2002, com aquele programa Fama da Rede Globo. Isso é técnica de canto americano. A letra da canção é do universo caipira, mas no timbre não há nada de música caipira ou sertaneja. Eles têm uma letra que diz uma coisa, mas a sonoridade revela outra coisa. Instrumentalmente, não tem nada de brasileiro. A beleza física claramente os ajuda, assim como para todos nesse segmento. Com exceção do César Menotti e Fabiano, que têm alguma origem de raiz. Eles foram considerados os "pais" do sertanejo universitário, pois estavam na entressafra do sertanejo romântico e esse atual. O uso do vibrato (tremor da voz) em Leonardo é menor se compararmos com os sertanejos românticos. O desenvolvimento do vibrato, na década de 1990, está relacionado ao vibrato da música mexicana. Podemos falar que eles fazem um pop country, mas não do country norteamericano em si. Victor e Leo ilustram uma correlação de como a música sertaneja se travestiu de música caipira. Esse nível de análise proposto no seu trabalho está correto. Avaliar a tríade: discursiva, instrumental e cênica. Mas, Victor e Leo não se diferem dos outros. Por sinal, de todos, quem está mais próximo de uma raiz é o Michel Teló - baseado no pagode caipira (o

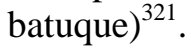

\section{(B-) Victor \& Leo: Chuva de Bruxaria, 2006 - álbum: Victor \& Leo Ao Vivo.}

Composição: Victor Chaves.

Azuis, vermelhas, brancas flores

Pintando o cerro dos meus olhares

Fossem linda garoa em cores

Molhando à tarde de ares solares

Chamam você, bem

Não fique aí, vem

Molhar meu beijo, te beijo também,

Maga magia de lua luz e

À noite virando dia

Água na boca secando na louca chuva de bruxaria

Hoje você vem, dizia

\footnotetext{
${ }^{317}$ Fada-álbum: Ao Vivo em Uberlândia, 2007.

${ }^{318}$ Chuva de Bruxaria - álbum: Ao Vivo em Uberlândia, 2007.

${ }^{319}$ Vida Boa - álbum: Ao Vivo em Uberlândia, 2007.

${ }^{320}$ Deus e Eu no Sertão: álbum: Borboletas, 2008.

${ }^{321}$ Entrevista de Ivan Vilela ao autor, 28 de novembro de 2014.
} 
Hoje você vem, dizia

De cada ponta de folhagem

Cai uma gota dos nossos banhos

Fada, samambaia, miragem

Doces varandas, sonhos estranhos

O que a beleza puser na mesa

Beba sem medo, vem da natureza

Maga magia de lua luzia a noite virando dia

Água na boca secando na louca chuva de bruxaria

Hoje você vem, dizia

Hoje você vem, dizia

Maga magia de lua luzia a noite virando dia

Água na boca secando na louca chuva de bruxaria

Hoje você vem, dizia

Hoje você vem, dizia

Chuva de Bruxaria é uma canção cantada exclusivamente por Victor Chaves (Deus e Eu no Sertão também). Victor tem uma voz mais melódica e suave, se comparada com o timbre grave da voz do irmão e isso lhe dá cadência ao cantar os versos. A narrativa é toda metafórica. A começar pelo título, Chuva de bruxaria, que é uma espécie de chuva de feitiço. Na bruxaria, há uma crença de que é possível adivinhar o futuro a partir da chuva. As gotas das chuvas formariam símbolos e padrões passíveis de predição. Estruturalmente, a canção tem uma licença poética com estrofes bem construídas. No refrão, o compositor invoca símbolos mágicos: “[...] maga (bruxa) magia de lua virando o dia (bruxa que faz a noite se transformar em dia), água na boca secando (está sendo enfeitiçado) na louca chuva de bruxaria (chuva imaginária de feitiço), hoje você vem, dizia (a bruxa maga que o enfeitiçou)".

A temática é predominantemente onírica e abstrata. As estrofes não apresentam um andamento lógico ou contextual. É quase um mergulho no inconsciente do compositor. O predomínio da estética textual (primazia da forma) vai até o final do último verso: “[...] o que a beleza puser na mesa (beleza da natureza), beba sem medo (não possui perigo), vem da natureza (essa beleza)". Se Fernando Fakri de Assis "Sorocaba" soube usar seu patrimônio familiar para investi-lo em capital tecnológico/artístico, Victor Chaves adotou outra estratégia social. A influência familiar da avó poetiza e escritora, o ambiente bucólico do interior mineiro, o contato com a cultura caipira, a iniciação precoce com a música estimulada pela família e a longa trajetória como músico de estrada lhe rendeu experiência musical e 
acumulação de capital lírico/artístico. A imagem "do poeta caipira", do "irmão devotado", do músico que dedilha o violão com "os olhos fechados", o "dom" prematuro da arte e a "genialidade" artística são disposições práticas que foram sendo construídas, atualizadas e naturalizadas ao longo de sua história social e também objetivadas em suas composições.

\section{(C-) Victor \& Leo: Fada, 2007 - álbum: Ao Vivo em Uberlândia.}

Composição: Victor Chaves.

Fada, fada querida

Dona da minha vida

Você se foi

Levou meu calor

Você se foi, mas não me levou

Lua, lua de encanto

Ouça pra quem eu canto

Ela levou minha magia

Mas ela é minha alegria

Vejo uma luz, uma estrela brilhar

Sinto um cheiro de perfume no ar

Vejo minha fada e sua vara de condão

Tocando meu coração

Madrugada de amor que não vai acabar

Se estou sonhando não quero mais acordar

Minha história linda, meu conto de amor

Algo aqui me diz que essa paixão não é em vão

O meu sentimento é bem mais que uma emoção

Eu espero o tempo que for

Minha fada do amor

"A canção Fada é inevitável em todas as apresentações", apontou Leonardo Chaves em um dos shows em que estive presente. O tema da narrativa é o amor, embora em um tom mais lírico e menos dramático ${ }^{322}$. Fada tem um enredo que prima pelos sentimentos, pelas emoções e por um romantismo marcado pela autoafirmação do narrador. É uma história sem resolução, uma construção imaginária com uma linguagem metafórica. Victor apresenta um cenário onírico/inconsciente: a relação entre os amantes é mediada pela fada (conto fictício histórico). Somado a isso, há elementos da natureza (não sui generis como na primeira

322 O melodrama foi comum ao sertanejo romântico dos anos 1990. Na época, as composições foram rotuladas pela crítica musical como "canção de corno" pelo uso excessivo de narrativas amorosas melodramáticas malacabadas. 
canção), mas de uma natureza que compõe elementos emotivos (a lua, a estrela e a madrugada). Frequentemente, o compositor vai à mídia justificar sua solteirice: a depressão, a personalidade introspectiva, a fama, a solidão e o não êxito nas relações afetivas e amorosas. Em Fada, o "artista Victor" reelabora os anseios do "homem Vitor", intercedido pela "fada do amor" imaginária, que um dia "com sua vara mágica de condão" tocará o seu "coração" e que ele "espera o tempo que for pela fada" que lhe trará o amor. Esse amor lírico é um estilo comum ao autor. Está presente em Amigo Apaixonado (o homem que mantém em segredo o amor a uma personagem e que só pode ser vivenciado por uma angustiante amizade). Há certa inadaptabilidade do artista em relação ao sucesso (uma manifestação quase anômica à fama). Em compensação, Victor sempre busca sossego na fazenda em Uberlândia (MG). Sua relação com o irmão mais novo é muito intensa. O compositor emociona-se publicamente ao falar da parceria com Leonardo na vida e na arte.

Ivan Vilela: Há toda uma emocionalização na gravação acústica - os ruídos e gritos da plateia. Ele [Victor Chaves] usa violão em cordas de aço, mas a banda também usa. Tem bateria, baixo e teclado. A banda é altamente profissional. $\mathrm{O}$ violão dele é elétrico, o qual tem um som comparado à guitarra. Nem "mão" tem o violão, se você olhar o corpo do instrumento. Esse violão é uma guitarra. Victor tem uma boa acuidade instrumental, mas é muito fácil o que ele está fazendo. A música é boa, mas tem sonoridades do pop: uma bateria gigantesca. Não tem nada de música sertaneja/caipira, ao menos, instrumentalmente ${ }^{323}$.

(D-) Victor \& Leo: Deus e Eu no Sertão, 2008 - álbum: Borboletas.

Composição: Victor Chaves.

Nunca vi ninguém viver tão feliz

Como eu no sertão

Perto de uma mata e de um ribeirão

Deus e eu no sertão

Casa simplesinha, rede pra dormir

De noite um show no céu

Deito pra assistir

Deus e eu no sertão

Das horas não sei, mas vejo o clarão

Lá vou eu cuidar do chão

Trabalho cantando, a terra é a inspiração

${ }^{323}$ Entrevista de Ivan Vilela ao autor, 28 de novembro de 2014. 
Deus e eu no sertão

Não há solidão, tem festa lá na vila

Depois da missa vou, ver minha menina

De volta pra casa

Queima a lenha no fogão

E junto ao som da mata

Vou eu e um violão

Deus e eu no sertão

Deus e eu no sertão

Deus e eu no sertão...

Nas entrevistas ou nos discursos de encerramento dos shows, Victor sempre deixa uma mensagem apoiada na família, na espiritualidade ou na estética da simplicidade. A canção Deus e Eu no Sertão foi música de abertura da novela Paraíso - Rede Globo (2009). Assim como em Vida Boa, o compositor traz à tona a rotina de um sertanista que vive em um ambiente rústico e é feliz ali por estar em contato direto com Deus. A narrativa aponta a presença da natureza (a mata, o ribeirão e o sertão); da simplicidade da casa; dos artefatos (fogão à lenha, rede para dormir); dos rituais católicos (missa); da música como inspiração para a lavoura: "trabalho cantando e a terra é a inspiração" e da viola como elemento cultural: “de volta pra casa, queima a lenha no fogão e junto ao som da mata vou eu e um violão". O uso da viola/violão como elemento socializador do caipira nos bairros rurais (nos ritos profanos - festas - e nos ritos sagrados - missas) cruza todo o enredo. Inclusive, uma narrativa muito próxima à registrada por Antonio Candido na coleta etnográfica de $O s$ Parceiros do Rio Bonito. No documentário Nada És Normal (2008), é filmada a casa e a fazenda dos bisavós paternos, nas quais os irmãos foram criados. Mesmo com a rusticidade e simplicidade do local, embora de geografia espacialmente vasta, esse ambiente promovido na canção é pouco conciliável com a história social dos músicos. Como hipótese, trata-se de uma forma de valorização de tal cultura tradicional no enredo da canção: a exaltação de um passado idílico, bucólico e quase irrecuperável. O reconhecimento nacional da dupla ocorreu junto ao auge do sertanejo universitário. Vida Boa e Deus e Eu no Sertão sinalizam respostas contrárias ao cenário pop da nova música sertaneja, que aos olhos do compositor, não reverenciava a "verdadeira" tradição da música caipira e nem tinha legitimidade cultural para 
representá-los. Posteriormente, Victor e Leo declarariam repúdio (sem apontar nomes ou duplas) ao novo cenário musical e chegaram a falar em "prostituição do sertanejo".

Ivan Vilela: A balada é americana. A afinação vocal deles é boa, mas hoje em dia não dá mais para avalizar isso com grandeza. Existe um aparelho chamado autotune que afina em tempo real - inclusive em um show ao vivo. Discursivamente, isso é uma picaretagem, porque não tem nada a ver com o que eles fazem e o tempo deles. Um só canta: na música caipira há duas vozes simultâneas. É uma balada romântica - música próxima à Jovem Guarda. Por sinal, isso é algo que se deve reconhecer, que o segmento que mais deixou marcas posteriores na música brasileira foi a Jovem Guarda. $\mathrm{O}$ rock dos anos 80, o sertanejo romântico ou universitário é tudo Jovem Guarda $^{324}$.

(E-) Victor \& Leo: O Tempo Não Apaga, 2013 - álbum: Viva Por Mim.

Composição: Leonardo e Victor Chaves.

Olhando o céu

Lembrei que tudo que vivemos não passou

E pra dizer mais

Pensei que temos outra chance de fazer

Nosso sol brilhar em mim

Em você

O tempo não apaga, não desfaz

$O$ beijo que eu desejo sempre mais

Não posso esquecer o seu olhar no meu

Eu sei que o nosso amor ainda não morreu

Olhando o céu

Lembrei que tudo que vivemos não passou

E pra dizer mais

Pensei que temos outra chance de fazer

Nosso sol brilhar em mim

Em você

O tempo não apaga, não desfaz

$O$ beijo que eu desejo sempre mais

Não posso esquecer o seu olhar no meu

$\mathrm{Eu}$ sei que o nosso amor ainda não morreu

O Tempo Não Apaga é uma faixa do álbum Viva Por Mim, lançado pela dupla em 2013. O CD marca a estreia de Leonardo Chaves como compositor, no caso, de oito das treze canções do disco (a função de compositor antes era destinada somente a Victor Chaves).

\footnotetext{
${ }^{324}$ Entrevista de Ivan Vilela ao autor, 28 de novembro de 2014.
} 
Outro ineditismo é o formato de videoclipe. Anteriormente, todas as gravações da dupla eram acústicas e ao vivo. $\mathrm{O}$ novo clipe conta com a presença da atriz global Carol Castro. $\mathrm{O}$ ambiente não é mais a roça ou o sertão: o cenário agora é o Rio de Janeiro. No clipe, Victor aparece apoiado em uma guitarra elétrica, não mais no violão. Leo Chaves interpreta ele mesmo: bronzeado, com os músculos definidos à mostra, caminhando pelas praias cariocas. Entre 2013 e 2014, Victor Chaves deixou o irmão carismático liderar o dueto. Antes, havia um equilíbrio nítido entre as funções musicais: Victor era o compositor, arranjador e músico, e Leo apenas assumia o canto. O cansaço e desgaste de seu irmão eram evidentes, dentro e fora dos palcos. A mudança para o selo Som Livre deixou a dupla em um formato mais comercial, Leo Chaves ocupou maior centralização e, com ela, teve que explorar mais seus atributos físicos. No início da carreira, o visual de Leonardo era muito diferente: usava camisa social, jeans e sapatos básicos (no próximo capítulo, deter-me-ei mais sobre a mudança da indumentária do artista). Há um consenso entre fãs e produtores musicais de que Victor está preparando o irmão mais novo para uma carreira solo - nada oficial até o momento.

Estruturalmente, essa canção não se difere muito das letras dos músicos sertanejos românticos da década de 1990: o amor impossibilitado pela morte, as lembranças afetivoemocionais e a não temporalidade de uma paixão. É uma música mais simples discursivamente se comparada ao repertório antigo da dupla e com refrãos redundantes e repetitivos. O apelo corporal apropriado por Leo Chaves e a mudança contextual das canções mereciam um capítulo à parte: o discurso dos irmãos de que a "música sertaneja vai de mal a pior" e "a falta da verdadeira música sertaneja de raiz" ficou um tanto quanto contraditório, examinando em sua prática. Provavelmente, os irmãos estejam cedendo às demandas do mercado fonográfico, assumindo cada vez mais um status musical pop.

Ivan Vilela: O modelo acústico é substituído pelo videoclipe, com cenários planejados e a presença de uma atriz global. Victor Chaves abre o vídeo, afinando uma guitarra elétrica. Ao tocar com os olhos fechados, ele quer passar a imagem de um artista romântico ou um gênio artístico [algo que o Bruce Springfield fazia]. Lembra letra do sertanejo romântica, mas não soa como música brasileira - nem no arquétipo musical: está muito mais para o pop americano. Essa música sequenciada é muito fruto da Jovem Guarda. Toda música ou obra de arte tem uma porção de informação e outra de redundância. Uma música como essa, o problema é o excesso de redundância e quase nada de informação. É uma música absolutamente redundante, pois você já sabe como se dará o curso da melodia, criando uma empatia com o público. Isso é uma virada pop na carreira dos irmãos! $!^{325}$

\footnotetext{
${ }^{325}$ Entrevista de Ivan Vilela ao autor, 28 de novembro de 2014.
} 


\section{Para um amor distante? Fernando e Sorocaba levam os amigos de caminhonete para balada}

Atendendo ao formato estipulado na introdução deste capítulo, mostrarei as canções produzidas na carreira de Fernando e Sorocaba. O intuito é analisar a estrutura discursiva e estrutural das canções, selecionando cinco músicas (ordenadas por A, B, C, D, E) produzidas em diferentes etapas na trajetória social dos artistas. Como foi realizado anteriormente com a primeira dupla, após a exposição e exame das letras das canções, incluirei a análise tímbrica e instrumental dos artistas, realizada pelo professor de música Ivan Vilela. No próximo item, discuto a identidade musical dos dois duetos sertanejos por meio de um retrato comparativo.

\section{(A-) Fernando \& Sorocaba: Paga Pau, 2009 - álbum: Vendaval.}

Composição: Fernando Fakri de Assis “Sorocaba".

Você diz que não me ama você diz que não me quer

Mas fica pagando pau, qual é que é

Todo dia seu teatro é exatamente igual

Você finge que me odeia, mas no fundo paga pau

Ela é atriz, ela faz cena, ela mete uma pressão

Se joga na minha frente, me engana não

Feito cobra mal matada, ela rebola, eu passo mal

Com o nariz empinado, ela é a tal

Se eu mando um xaveco, ela finge não ouvir

Mas se eu grito: "Olha a bruxa!", vem discutir

Sua psicologia tá um tanto quanto errada

Ou me aceita de uma vez, ou tá danada!

Você diz que não me ama, você diz que não me quer

Mas fica pagando pau, qual é que é

Todo dia seu teatro é exatamente igual

Você finge que me odeia, mas no fundo paga pau

A expressão "Paga Pau" pode ser definida como um indivíduo que gosta de adular ou "puxar o saco" de alguém com a intenção de conseguir algum tipo de benefício. Ao lado de Bala de Prata, Paga Pau foi a música responsável pelo boom comercial da dupla a partir de 2008. É embalada por um ritmo animado e dançante. No enredo, o personagem se irrita com essa atuação da pretendente afetiva, que ao mesmo tempo o esnoba, "mas no fundo paga pau". 
Sorocaba ainda solta umas onomatopeias como "uhu" e "yahoo" no final da frase. Os shows da dupla parecem uma verdadeira festa pop. Há quem dance em volta das mesas ou pule alto na pista única do espetáculo. Paga Pau é uma espécie de "estética da farra". O personagem é autoconfiante (o "rei do camarote") e faz questão de destratar a encenação da moça: "ela é atriz, ela faz cena, ela mete uma pressão, se joga na minha frente, me engana não, feito cobra mal matada, ela rebola, eu passo mal, com o nariz empinado, ela é a tal”. Há pouca preocupação na narrativa com o uso de estereótipos machistas: "se eu mando um xaveco, ela finge não ouvir, mas seu eu grito 'olha a bruxa', vem discutir" ou de clichês machistas: "sua psicologia tá um tanto quanto errada ou me aceita de uma vez, ou tá danada”. Discursivamente, a música é muito semelhante à produzida pela nova geração do sertanejo universitário. A temática (depreciada) do sertanejo romântico dos 1990 trazia uma estética mais voltada ao sofrimento da relação amorosa do que estereótipos sexistas. Piunti esclarece: “A temática do sertanejo universitário traz essa ideia do 'rei do camarote': um cara que gosta de ostentação, que passa a ouvir música sertaneja, porque as meninas gostam do estilo"326.

\section{(B-) Fernando \& Sorocaba: Madrid, 2010 - álbum: Fernando \& Sorocaba Acústico.}

Composição: Fernando Fakri de Assis "Sorocaba".

Que saudade, amor

Estou sabendo que aí na Espanha tudo é lindo

Você me deixou

E aqui dentro meu coração ficou partido

Nessa cidade, não vou mais sorrir

Que bom seria

Se São Paulo fosse do lado de Madri

No puedo más mi corazón

Tá doendo aqui na solidão

No puedo más vivir sin ti

Volta logo pra São Paulo

Ou eu vou pra Madri

Que saudade, amor

Volta logo pro hemisfério sul do mundo

Ficar sem você

Me mostrou o quanto é bom estarmos juntos

Sonho tão lindo é ter você aqui

Que bom seria

Se São Paulo fosse do lado de Madri

\footnotetext{
${ }^{326}$ Entrevista de André Piunti ao autor, 28 de novembro de 2014.
} 
No puedo más mi corazón

Tá doendo aqui na solidão

No puedo más vivir sin ti

Volta logo pra São Paulo

Ou eu vou pra Madri

A canção Madri (ou Madrid) de Fernando e Sorocaba foi um grande sucesso nacional em 2010. Sorocaba costuma ser a primeira voz da dupla. No entanto, aqui, Fernando Zorzanello faz dueto em terça com o companheiro - acompanhado por um violão em cordas de aço. A estrutura discursiva da música é predominada por elementos urbanos que cruzam a narrativa: a amada vai para Madri na Espanha, mas o personagem continua a morar no Brasil (em São Paulo), cerceado pela distância entre os dois continentes (ambos estão em uma metrópole), vivendo a saudade reprimida, inconformado e deprimido com o rompimento temporário da relação amorosa. É uma narrativa muito próxima à realizada por artistas como Chitãozinho e Xororó, Leandro e Leonardo, Zezé Di Camargo e Luciano e João Paulo e Daniel - ícones do sertanejo romântico da década de 1990. Nos shows, após a canção Madri, Sorocaba sempre pergunta ao público: "Quem nunca viveu um amor à distância". O intercâmbio internacional é uma eficiente isca no pano de fundo do enredo amoroso. Traduz as relações de fusão e fissão (amor à distância) vivenciadas pelos jovens que compõem a nova classe-média brasileira. Há uma característica importante dessa música, que deve ser destacada: o uso do canto em castelhano - forma mercadológica almejada pelos artistas para conquistar o público sul-americano.

Ivan Vilela: Os outros estão caindo em venda. Então, eles estão querendo criar uma nova indexação para o trabalho, como é o caso do acústico. Quando um artista grava um CD acústico é porque as vendas estão caindo. Isso que o Fernando e Sorocaba apresentam não é um formato acústico: tem uma baita banda atrás. Acústico é o artista e o instrumento. Esse aparato performático é pop. O Fernando usa violão em cordas de aço. O tipo de impostação vocal do Fernando é semelhante ao Rick Martin, mas ele canta bem. Há uma semelhança de letra com o sertanejo romântico. E também uma balada romântica. Esse é o milionário [se referindo a Sorocaba quando inicia a apresentação]. A voz dele é imposta, como dos programas musicais como o Fama e The Voice. Não tem um nome para isso, mas é igual a todos. Este Sorocaba é o dono da banda. Ele já arrumou vários "Fernandos"”27.

(C-) Fernando \& Sorocaba: A Casa Caiu, 2010 - álbum: Fernando \& Sorocaba Acústico.

Composição: Fernando Fakri de Assis "Sorocaba".

\footnotetext{
${ }^{327}$ Entrevista de Ivan Vilela ao autor, 28 de novembro de 2014.
} 
Eu tenho mais o que fazer

Será que você me entende?

Quero um amor decente

Nossa paixão desmoronou

E só você não viu

Sua casa caiu

Tô grilado, encanado

Por que armou isso comigo?

Tô pirado, revoltado

Não vou ser mais seu ombro amigo

Para, para, para, tá louca

Tá tudo errado, fica longe da minha boca

Para, sua casa caiu de vez

Eu sei do seu passado

Você faz tudo errado

O amor tá acabado

Eu já tô cansado

Da sua estupidez

Eu tenho mais o que fazer

Será que você me entende?

Quero um amor decente

Nossa paixão desmoronou

E só você não viu

Sua casa caiu

A Casa Caiu é um título metafórico (quer dizer, deu tudo errado, nossa história acabou etc.). Existe o recurso de perguntas retóricas (cobranças afetivas da mulher, um dia amada por ele). A canção tem uma linguagem de valorização de um amor pessoal positivo: ele que decide os rumos ou o término do relacionamento. A mulher, ao tomar conhecimento do rompimento, fica em uma situação subordinada à decisão masculina e é apresentada, em um tom machista, como sendo desequilibrada ("para, para você está louca”). Ela também é destratada ("eu sei do seu passado") por uma provável traição ("você fez tudo errado"). Mas o homem parece estar bem decidido: "meu amor está tudo acabado!". Em vez de sofrer dramaticamente, ele exala uma autoconfiança com sua decisão (mesmo que haja briga ou a “casa caia"). Utilizam-se expressões informais, como "pirado, grilado e encanado". A modernização do universo temático é comum na obra de Sorocaba. Aliás, uma das marcas registradas do sertanejo universitário. Esse vocábulo moderno é projetado a um público mais jovem e urbano, permitindo identificação do artista com seu consumidor. 
Ivan Vilela: Se você assistir ao primeiro Rock in Rio com o Red Hot Chili Peppers é a mesma coisa: um palco gigantesco, com luzes, os artistas pulam. Só que isso é pop, não tem nada de sertanejo ${ }^{328}$.

\section{(D-) Fernando \& Sorocaba: Livre, 2013 - álbum: Sinta Essa Experiência.}

Composição: Fernando Fakri de Assis "Sorocaba".

\section{Vamos girar, girar}

Até o dia clarear

A vida é muito curta, não vou parar

Aumenta o som da camionete põe no 12 sem ter dó

Toca um Tião Carreiro um Chitãozinho e Xororó

Sou metade santo, outra metade malandragem

Estiloso na fazenda e selvagem na cidade

Esse é meu jeito e ninguém consegue me mudar

Acordo em um canto e vou dormir em outro lugar

Livre, é o meu jeito de ser, nasci fui criado desse jeito

Meio louco imperfeito, não queira entender

Livre, é o meu jeito de amar, eu quero ser a sua liberdade

Seu segredo mais selvagem, quem te faz sonhar.

Vamos girar, girar

Abra as asas pra voar

Não existem limites, vem se entregar

Eu acelero na balada, e no meu rancho encontro a paz

Não perco tempo pra dormir, eu quero é mais

Desligo o celular e ouço a voz do coração

$\mathrm{Eu}$ quero ouvir mais sim e menos não

Esse é meu jeito e ninguém consegue me mudar,

Acordo em um canto e vou dormir em outro lugar

Em redes sociais, como o Facebook e o Instagram, Sorocaba faz questão de mostrar sua vida particular: fotos do dia a dia e da sua própria rotina pessoal (a pesca, o churrasco junto dos amigos, montaria a cavalo, o haras, a fazenda, os hobbies etc.). Pode-se considerar que a canção Livre seja sua própria autodescrição: o artista sertanejo e empresário que divide seu cotidiano entre a fazenda (denominada aqui como "rancho") e a movimentação urbana frenética da cidade (referida como "balada") mediada por sua caminhonete (sucesso econômico e símbolo de status da classe-média ascendente). A passagem "sou metade santo e outra metade malandragem" soa como uma alusão à sua dupla participação como artista (santo) e empresário (malandragem). Esses pares de oposições semânticas continuam: “estiloso na fazenda e selvagem na cidade". Ou seja, uma personalidade excêntrica, que o

\footnotetext{
${ }^{328}$ Entrevista de Ivan Vilela ao autor, 28 de novembro de 2014.
} 
permite ser estiloso em um ambiente mais interiorano e mais rústico em um espaço urbano. Esses traços individuais ("é o meu jeito e ninguém consegue me mudar") de Sorocaba fazem parte de sua condição econômica privilegiada que o possibilita "acordar em um canto e dormir em outro lugar", sem se preocupar com as condições objetivas de existência social. O artista como representante do novo sertanejo parece ter suas próprias tradições. Ao aumentar o som da caminhonete: "põe no [volume] 12 sem ter dó [do barulho que ecoa do carro] e toca um Tião Carreiro e um Chitãozinho e Xororó”, o compositor valoriza os artistas, a ponto de escutá-los no interior de sua caminhonete, em alto volume, não se importando com a apreciação do som que vaza explicitamente das potentes caixas de reprodução musicais alocadas na traseira do veículo. O autor também reafirma o estilo da nova classe-média universitária brasileira, que tem o convívio permeado pela tradição (cidade de origem e família) e a urbanização (o acesso às universidades e a nova residência em uma cidade grande). Nos últimos anos, com a extensão do ensino superior de educação, parcelas significativas desses jovens espalhados pelo vasto território brasileiro foram às cidades metropolitanas, em busca dos estudos universitários. Um jovem "que quer ouvir mais sim, e menos não", e "não perde tempo para dormir", afinal, concilia os estudos, o trabalho e a diversão "na balada", encontrando a "paz no rancho" ou no interior, quando está cercado de sua família, pois "desliga o celular para escutar a voz do coração". A narrativa é construída por elementos de autoafirmação desse jovem urbano que almeja ser "livre", porém que aceita as contradições da sua experiência social.

Ivan Vilela: Isso é pop! Tem patrocínio da Chevrolet e tudo. É uma música pop cantada em terça. O cara [Fernando] se ajoelha para fazer um solo, um desempenho do pop rock internacional, embora não haja movimentação e ambos não mudam de posição nunca. O clipe é um distúrbio ${ }^{329}$.

\section{(E-) Fernando \& Sorocaba: As Mina Pira, 2013 - álbum: Homens e Anjos.}

Composição: Fernando Fakri de Assis "Sorocaba" e Thiago Servo.

Dá balão no namorado

Desliga o celular

Pode vir, vem festar

Tá tudo programado no apê do Guarujá

Hoje não vai prestar

O churrascão vai comer solto

A champa não pode faltar

Liga pra quatro ou cinco amigas

\footnotetext{
${ }^{329}$ Entrevista de Ivan Vilela ao autor, 28 de novembro de 2014.
} 
Traz o biquíni

Que hoje o sol tá de rachar

As mina pira, pira

Toma tequila

Sobe na mesa

Pula na piscina

As mina pira, pira

Entra no clima

Tá fácil de pegar

Pra cima!

O cenário do videoclipe é o mesmo descrito na canção: rapazes ricos preparam uma festa particular em um luxuoso apartamento no Guarujá (SP). Enquanto bebem champanhe à beira da piscina, no estilo "rei do camarote", belas e atraentes moças dançam de biquíni para os anfitriões. As convidadas se embebedam com tequila, brindam e caem na piscina. No clipe ainda, um senhor viúvo e solitário de setenta anos se sente perturbado com o barulho da festa do apartamento acima. Ele faz de tudo para que a moçada pare com a baderna, mas sem êxito. Irritado, resolve bater à porta para pedir silêncio, mas acaba ficando bêbado e rodeado por sete mulheres sensuais de biquíni. As Mina Pira (a grafia errada é premeditada pelo autor) foi lançada em 2013 e se popularizou como um dos grandes hits da dupla até hoje. Entre 2007 e 2015, as temáticas festivas da farra masculina não foram abandonadas por Fernando e Sorocaba. De lá para cá, o teor apelativo-sexual e a reprodução de estereótipos machistas só encorpou. Em músicas como A Casa Caiu (2010), o discurso sexista coexistia sutilmente apenas na cobrança afetiva da parceira (“eu já sei do seu passado"). Mas, Sorocaba soube, pouco a pouco, ir retraduzindo o senso comum partilhado por seu público masculino nas composições. Aliás, os erros gramaticais ou ortográficos não têm a mesma função estratégica de "caipirizar" a canção como faz Victor Chaves. O artifício de Sorocaba tem outros dois fundamentos: um deles é trazer o "internetês" - linguagem usada no meio digital pelos jovens, para que as letras das canções se tornem fáceis de "pegar" e, assim, tenham adesão desse mesmo público usuário/consumidor. A segunda tática é tênue, embora persuasiva: o desrespeito à norma culta da língua é usado intencionalmente para tornar o ritmo da música mais acelerado e permitir que os refrãos repetitivos camuflem a compreensão textual da letra da canção. O resultado é visto no show-balada promovido pelo artista/empresário: o enredo vulgarizado de As Mina Pira faz com que o público feminino dance sem sequer notá-lo. Se em outras canções, o personagem não aceita a traição da companheira, nessa trama, ele tem 
outra postura com "a mulher dos outros". Pede que ela dê "balão no namorado" e que "desligue" o celular para não se estressar com cobranças, afinal, tem uma festa programada no "apê do Guarujá". Mas, o convite da "festa sexual" não é omitido: "hoje não vai prestar, o churrascão vai comer solto, a champa [champanhe] não pode faltar". Ou seja, ela pode se "divertir" porque estará bêbada e cederá ao apelo do sexo casual. O personagem faz um último pedido: "liga pra quatro ou cinco amigas, traz o biquíni, que hoje o sol tá de rachar". Portanto, a convidada já sabe que não vai à praia no Guarujá e sim para uma festa privê à beira da piscina para trair o parceiro e ainda de quebra levar as amigas para uma orgia sexual. Só que não é fácil "o churrascão comer solto". A promessa de que "a champa não pode faltar" é reservada somente aos homens, afinal, eles devem ficar sóbrios para "outra festa". O champanhe caro faz parte do ritual de ostentação da festa exclusiva masculina. A bebida alcoólica destinada às mulheres é a tequila. Lentamente, depois das primeiras doses inofensivas, as convidadas ficam embriagadas para o bel-prazer dos anfitriões ricos. No começo da festa, apenas se alegram e dançam, depois sobem na mesa. No final, elas estão bêbadas e como "o sol tá de rachar" pulam na piscina. Então, elas "entram no clima" e os rapazes podem atacar "porque tá fácil de pegar" e todos mergulham na piscina "pra cima" delas. A narrativa prima pelo hedonismo individualista do personagem "playboy", enquanto a figura social feminina é transformada em uma mera peça do utilitarismo sexual masculino. À primeira vista, o ritmo acelerado da balada até chega a dissimular a temática machista do repertório, tornando o ouvinte vítima da alodoxia cultural ${ }^{330}$, ou seja, levando-o ao engano proposital no entendimento do enunciado. Tomemos o exemplo do jornalista André Piunti: "Sorocaba faz músicas mais felizinhas e bobinhas para agradar as mulheres [...] Ele coloca a mulher como vencedora nas disputas das músicas, e os homens não aparecem mais como o bonzão. Agora é a mulher quem dita a relação ou é o homem que se dá mal"331.

Ivan Vilela: Esse hibridismo tímbrico é coisa da música pop ou do Elton John. O instrumento é apenas uma peça de encenação e diferenciação. Tudo cheira a lucro. Não consigo ver valor artístico ou instrumental nisso. Tem um pouco do que o Martins fala, da diferença da música caipira para a sertaneja: a força motriz é o lucro ${ }^{332}$.

\footnotetext{
${ }^{330} \mathrm{O}$ pequeno-burguês é ansioso em relação à inclusão, [ele] faz a reverência ao acaso diante de tudo o que possa se parecer com cultura [...]. Essa boa vontade, desprovida dos referenciais ou princípios indispensáveis à sua aplicação [...] e o transforma na vítima proposital da alodoxia cultural, ou seja, de todos os equívocos de identificação e de todas as formas de falso-reconhecimento [...] além de encontrar nessa falsa-identificação [...] o princípio de uma satisfação ainda tributária (Ibidem, 2007, p. 300).

${ }^{331}$ André Piunti ao autor, 28 de novembro de 2014.

${ }^{332}$ Entrevista de Ivan Vilela ao autor, 28 de novembro de 2014.
} 


\section{Os retratos de uma identidade musical: o caipira Galdino e o sertanejo empreendedor}

O intuito fundamental deste capítulo foi examinar as temáticas do cancioneiro dos novos artistas da música sertaneja e, concomitantemente, interpretar o valor discursivo da obra musical articulado à história social dos seus produtores. Além disso, foi realizada uma apresentação mínima dos artefatos instrumentais dos artistas. Foram selecionadas cinco canções de cada dueto referentes a fases distintas da trajetória social, detectando possíveis transformações nas narrativas. Faz-se oportuno, então, um quadro comparativo entre as produções musicais de Victor e Leo e Fernando e Sorocaba. Entre 2005 e 2006, a indústria fonográfica brasileira enfrentou o aumento da comercialização, distribuição e consumo do mercado musical ilegal. Na prática, desde o início dos anos 2000, as gravadoras já lidavam com a expansão das novas tecnologias de reprodução e compartilhamento de conteúdos digitais. Esse cenário alterou radicalmente o formato musical tradicional, baseado na compra e venda de CD's e fitas cassetes. Uma parcela dos artistas sertanejos se beneficiou desse rearranjo, passando a usar as novas plataformas digitais para divulgação do trabalho. Não foi à toa que o formato acústico se popularizou rapidamente. O sucesso econômico dos músicos tornou-se dependente das apresentações ao vivo com plateias numerosas. A rentabilidade comercial viria da venda dos ingressos e dos cachês pagos dos contratantes. Em meio a esse inóspito contexto, surgiria o movimento universitário na música sertaneja.

A consagração nacional de Victor e Leo aconteceu concomitante à ascensão da vertente universitária. Nunca refutaram tal rótulo, mesmo no início, mas também nunca o assumiram. A nova música sertaneja tinha como teor cancioneiro as baladas, as festas e a vida urbana. Em 2007, os experientes músicos mineiros (ainda quase anônimos) souberam alterar tal cenário: trouxeram os elementos do universo caipira para destacarem-se de seus concorrentes musicais. Essa valorização da estética caipira liderada pelos irmãos lhes ofereceu legitimidade no âmago da música popular brasileira. No entanto, as temáticas das canções de Victor e Leo alteraram-se com a consolidação fonográfica. Como apontado na análise de O Tempo Não Apaga, 2013 (quadro E), os irmãos passaram a optar por letras mais próximas do pop mundial. O discurso de revitalização do caipira foi sendo substituído, gradualmente, por elementos mais modernos (as relações de amor, a vida urbana e os cenários 
paradisíacos). O formato acústico foi incrementado com novos videoclipes e o uso predominante do violão por Victor Chaves ganhou paridade com a guitarra elétrica.

A partir de 2007, Fernando e Sorocaba também se firmaram nacionalmente. Com enredos voltados para o ambiente tecnológico e urbano (festas, baladas, bebidas, paixões e carros), os músicos alcançaram plateias e públicos numerosos. Sorocaba esteve cercado desde cedo com o universo do agronegócio. Acompanhou de perto os circuitos agrícolas do interior do estado de São Paulo, fortemente espelhado no modelo de prosperidade rural norteamericana (um interior que coexiste com o urbano). Fernando Fakri possui uma dupla identidade na música sertaneja: artista e também empresário do gênero. Suas letras são consideradas mais "comerciais e modernas" voltadas para o consumo em festas e baladas dos jovens urbanos. As narrativas do compositor funcionam como alegorias das mudanças econômicas, sociais e culturais ocorridas no Brasil, desde o início dos anos 2000: a formação de uma nova classe-média, a extensão do sistema de ensino universitário e o fortalecimento econômico do agrobusiness. Esse último responsável por injetar cifras milionárias nos circuitos da música sertaneja - sendo a Festa do Peão de Boiadeiro de Barretos seu maior exemplo. Um novo público com acesso às mídias digitais que praticamente não compra mais CD's ou DVD's. Preferem assistir seus ídolos em shows ao vivo e participar de rodeios e festas que compõem o gênero sertanejo. Sorocaba não abre mão do seu chapéu de caubói norte-americano no estilo texano. Seus dispositivos de representação musical estão mais próximos da geração do sertanejo moderno dos anos 1970 (influenciada pela Jovem Guarda), como Milionário e Zé Rico, Leo Canhoto e Robertinho, Sérgio Reis e também dos ícones do sertanejo romântico dos anos 1990, como Zezé Di Camargo e Luciano, Chitãozinho e Xororó, Leandro e Leonardo e João Paulo e Daniel. Em suas composições, não existe um caipira ou um sertanejo. Somente um jovem urbano que coexiste com tal tradição. No máximo, um caubói moderno da cidade grande.

No programa Fantástico ${ }^{333}$, o artista não abriu margem à dúvida do seu contraste com Victor Chaves: "Se você compor [sic] algo muito rebuscado, que só você entende, não dá certo. Se você compor [sic] algo muito popular, você é muito bobinho". O adjetivo "bobinho" atuou como sinônimo de ingênuo, insinuando certa inocência na resposta anterior de Victor: "Fiquei lembrando a avó contando história da carochinha, história de um sapo que caiu na

333 Bem Sertanejo, quadro apresentado no programa Fantástico (Rede Globo), exibido em 19 de outubro de 2014. Convidados: Victor e Leo e Fernando e Sorocaba. 
lagoa e é recebido com uma festa no céu". O quadro Bem Sertanejo, apresentado pelo cantor Michel Teló, resolveu reunir as duas duplas para "mostrar esse negócio milionário que é a música sertaneja". Mostrou mais. Foi uma clara ilustração dos conflitos simbólicos existentes no interior do gênero. Inclusive, as disputas reveladas no discurso de um e de outro.

Instrumentalmente, Ivan Vilela não vê diferença alguma entre as duplas Victor e Leo e Fernando e Sorocaba:

Eu refuto também qualquer semelhança com a música caipira ou sertaneja, usando argumentos musicais. Não é uma questão normativa ou ideológica. É música feita para vender. Quando cessar, renova-se e outros surgem. Todos são estrelas cadentes. Eles vêm, aparecem e somem. É isso com outros gêneros da música popular brasileira, e com eles não é diferente. A música sertaneja de Victor e Leo é igualzinha a essas produzidas pelos universitários. Ainda que discursivamente as letras compostas por eles remetam ao universo caipira, isso não ocorre instrumentalmente. Muda-se a embalagem, mas o produto é o mesmo. Não há nada de música caipira na sonoridade instrumental deles. Essas apropriações têm como objetivo a alta vendagem da música pop. Chitãozinho e Xororó e os sertanejos dos anos 1990 estão mais próximos do gênero romântico. Não são propriamente pop. Estão mais pertos de Roberto Carlos e Fábio Júnior - música romântica de alta vendagem é claro. Há algum traço da música caipira para os casos que analisei, mas quase nada. Talvez, apenas no jeito de cantar, mas um cantar com vibrato exagerado. A impostação vocal deles está mais para o pop americano. Mesmo que a letra de Victor e Leo se rotule caipira, o produto é outro. Tenha o exemplo da alegoria do homem Galdino: se o discurso é contraditório, observe o que as mãos revelam ${ }^{334}$.

Independentemente se Victor e Leo e Fernando e Sorocaba fazem música caipira/sertaneja ou não, ambos os duetos são produtores culturais estabelecidos fonograficamente. A identidade musical caipira ficou guardada apenas na história social do gênero. Tais representações reafirmam a coexistência desse personagem somente no discurso, como um recurso estratégico temporal na carreira dos novos músicos sertanejos. Há quase um século, o uso da figura caipira na música popular brasileira é apenas sintomático: grupos que querem se distinguir, apoiados no discurso da "autenticidade artística", contra uma arte supostamente comercial produzida, quase sempre, por seus concorrentes diretos de mercado fonográfico. Esse fundamento, mesmo que reatualizado, persiste até os dias de hoje. A contestação de Victor e Leo ou a aceitação de Fernando e Sorocaba sobre a validade (ou não) do movimento universitário exemplifica o atual contexto da música sertaneja: em um mesmo gênero, existem duas identidades musicais e também dois diferenciadores mercadológicos (vide página):

\footnotetext{
${ }^{334}$ Entrevista de Ivan Vilela ao autor, 28 de novembro de 2014.
} 


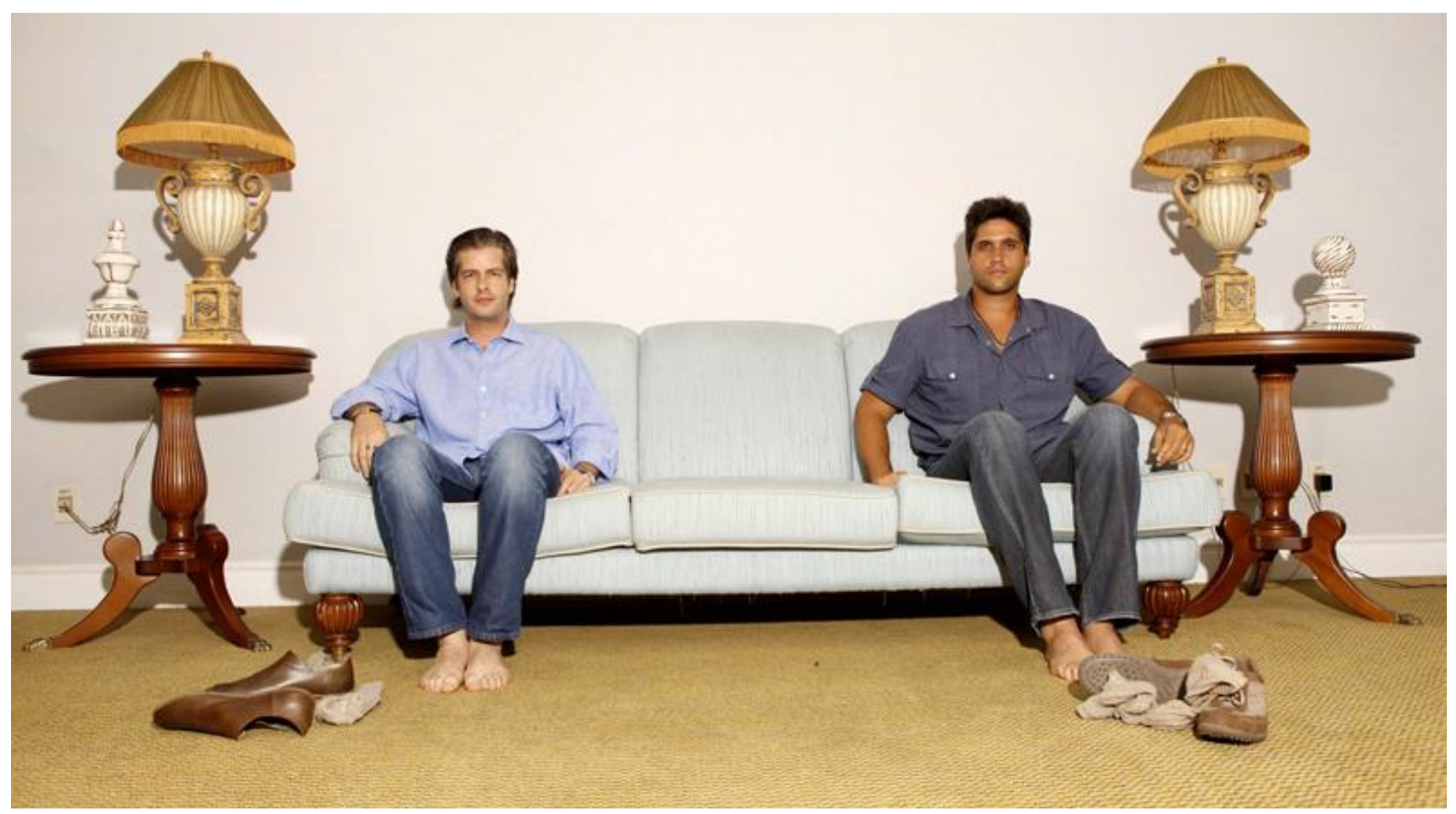

Título original: Bregapop. Fonte: Revista Gloss, outubro de 2010.

O caipira Galdino: Victor e Leo assumem a figura imagética do homem do campo com os pés descalços. Uma identidade muito próxima ao quadro Abaporu de Tarsila do Amaral e de todo movimento antropofágico modernista.

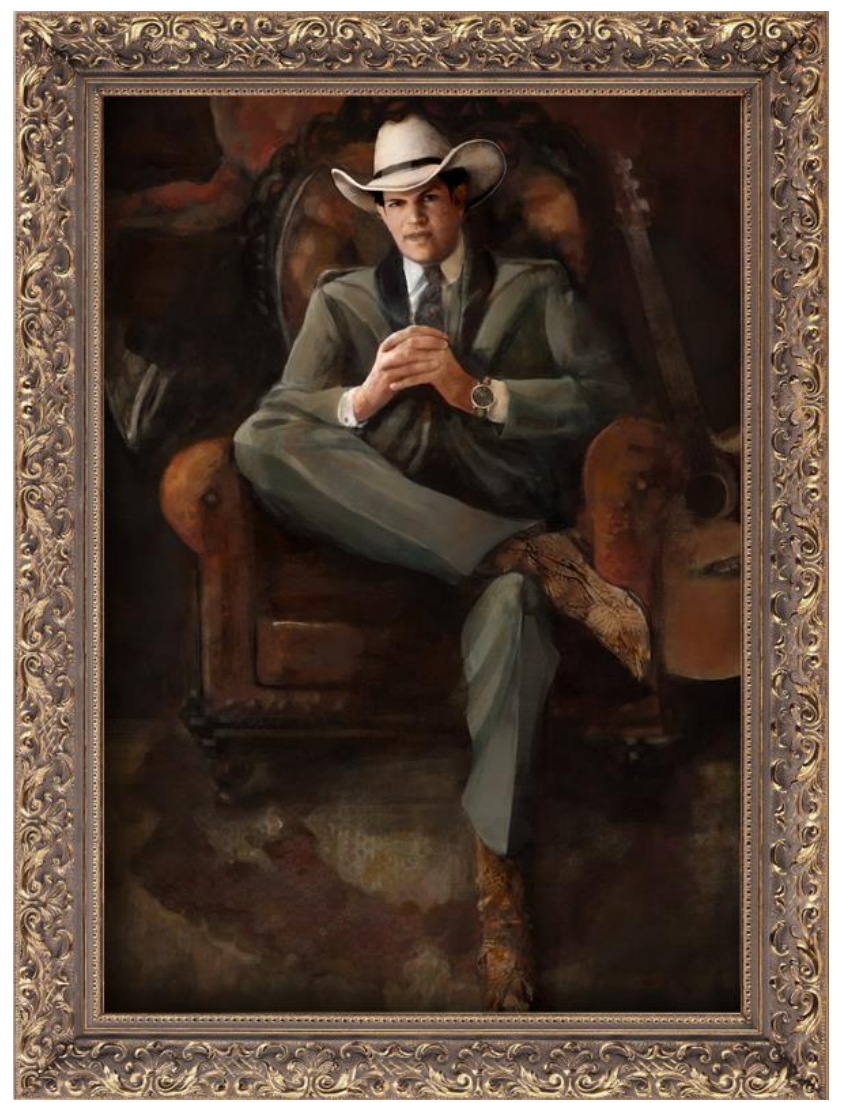

Fonte: Revista $G Q$, fevereiro de 2012.

O sertanejo empreendedor: o retrato de Fernando Fakri de Assis "Sorocaba" acena à identidade moderna do universo rural brasileiro. Um interior agrícola próspero, urbanizado e rico exportador. Na abertura original da reportagem, anunciava-se: "Ele não nasceu no campo, nunca foi pobre, nem trabalhou na roça". 


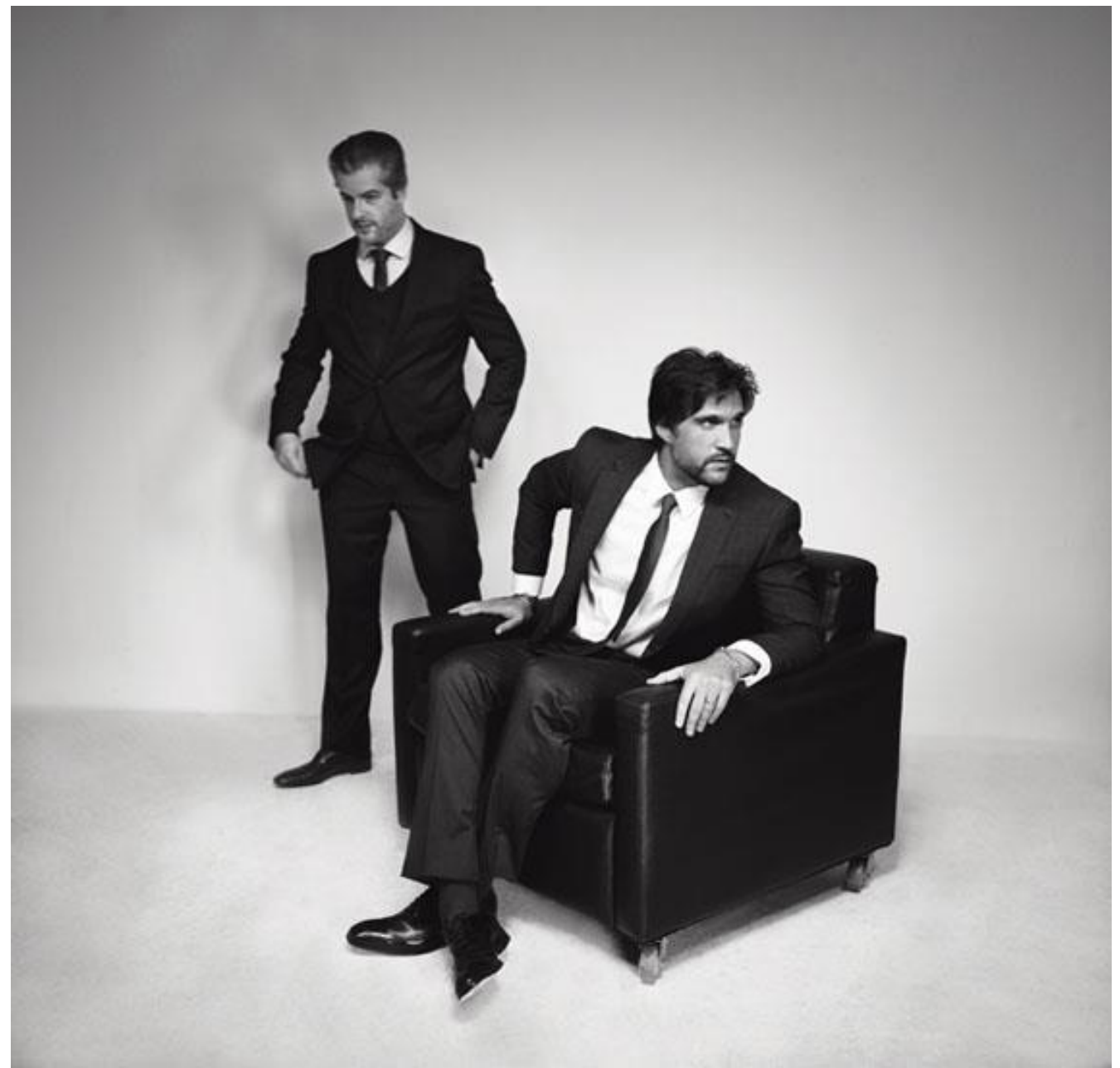

Fonte: Portal Glamurama/UOL, 30 de agosto de 2015. Foto: André Schiliró/Revista Poder.

Título original: Revista Poder ressalta as semelhanças - e muitas diferenças - de Victor e Leo.

"Vitor é notívago, sedutor, cita Platão e Aristóteles. Ele mora sozinho em um apartamento, tem livros, filmes, música, pôquer e o gosto por charutos como hobbies. Já Leonardo é do dia, tem esposa e dois filhos, é fã de Michael Jackson, Axl Rose e Freddie Mercury, passa mais tempo na fazenda do que em casa e pratica quase todos os tipos de esporte".

Esse é o novo retrato de Victor e Leonardo Chaves. Em 2013, os músicos foram contratados pelo escritório das Organizações Globo (Som Livre) e, desde então, a figura social "caipira" dos irmãos mineiros foi sendo modernizada pela gravadora a fim de atender a nova configuração pop do mercado musical sertanejo. Leo (sentando à direita) vestiu o modelo comercial do sertanejo empreendedor e, hoje, ele não está muito diferente de seu concorrente, o cantor Sorocaba. Victor (em pé e à esquerda) ilustra com exatidão a parábola do homem Galdino: tanto no plano do discurso quanto na letra da canção, o compositor louva a herança caipira, mas na prática, a héxis corporal do músico confessa uma inerente contradição. Nos palcos, suas experientes mãos revelam os acordes feitos na guitarra eletrificada. Nem mesmo usando um terno sofisticado para a foto, ele mantém uma linguagem corporal concordante. No entanto, vestindo terno ou não, o olhar de Leonardo não deixa dúvida: ele quer o Olimpo. Mas, para isso, a presença do irmão primogênito é ainda essencial - é o seu diferenciador mercadológico. Para Victor: "O que nos mantém juntos é o amor de irmão. Se não fosse isso, não estaríamos aqui". Esses laços afetivos e sociais são os responsáveis por mantê-lo ainda "aqui”, ao lado do irmão. Digo "aqui" até mesmo para ser registrado nessa fotografia. Nesse novo retrato musical, o compositor mal sabe para onde olhar e nem mesmo consegue situar a posição das pernas e das mãos. 


\section{O palco é folk: o show sertanejo de Victor e Leo}

A música melhora a vida das pessoas. A única forma de retribuir, tanto para mim quanto para o Victor, é nos tornarmos músicos melhores. A cada dia que passa, fazer uma música de melhor qualidade, com mais sentimento e verdade musical. É isso que a gente quer: subir no palco e abrir sorrisos e transformar a vida das pessoas. É a nossa missão aqui. Eu só tenho a agradecer a todos vocês que atravessam quilômetros e quilômetros para estarem aqui. Não tem como retribuir isso! A única forma é se comprometer em fazer o melhor no palco, no estúdio, para que vocês possam se emocionar de alguma forma com a nossa música e a nossa $\operatorname{arte}^{335}$.

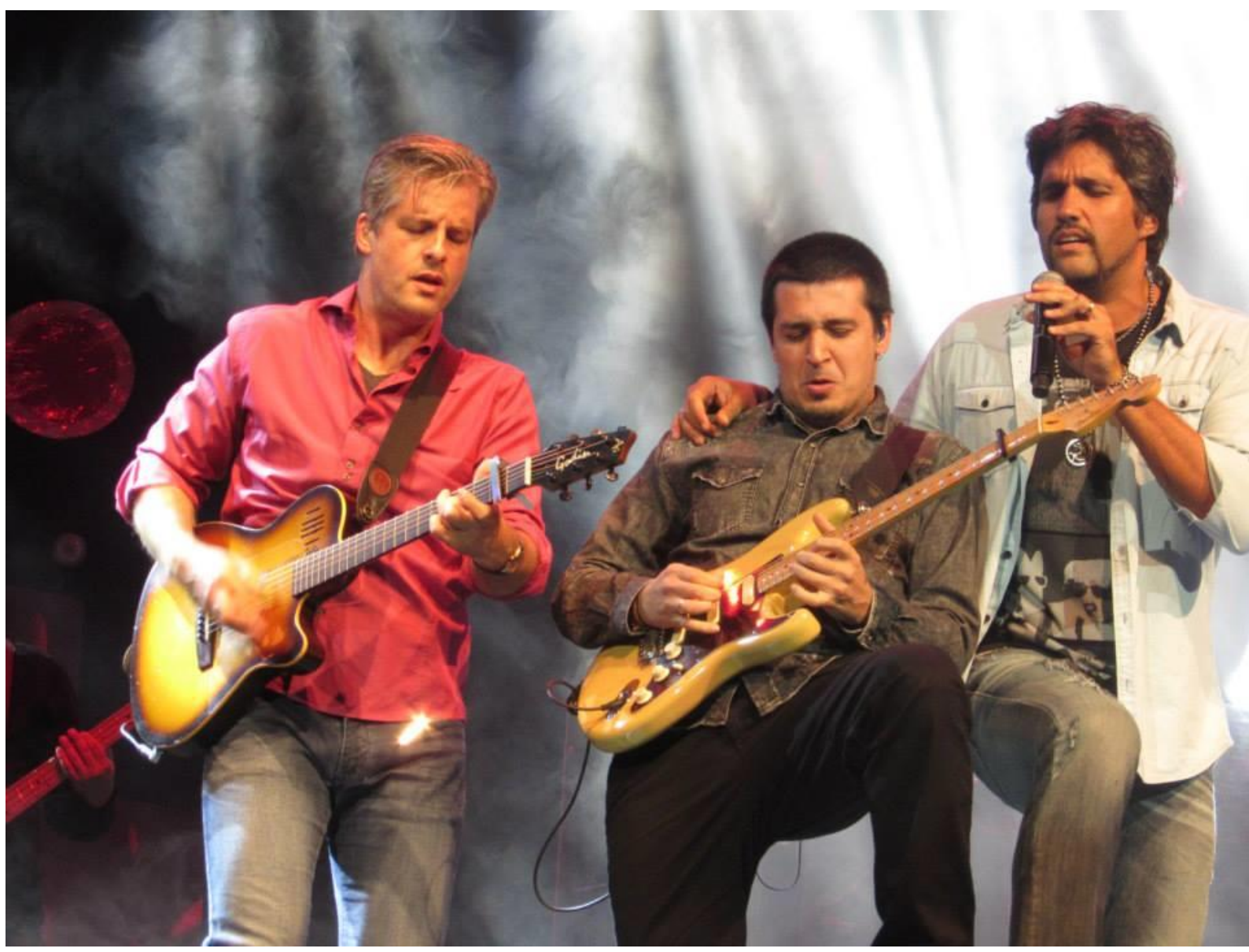

Show no Espaço das Américas: Victor Chaves (à esquerda) apoiado no violão em cordas de aço, o guitarrista Beto Rosa (ao centro) e Leonardo Chaves nos vocais (à direita). Os solos instrumentais têm espaço central nas apresentações dos irmãos. Victor convida os instrumentistas da banda a participarem do espetáculo. Usualmente, é o próprio quem dedilha a guitarra e o violão, por minutos a fio e sem o acompanhamento da voz do parceiro. $\mathrm{O}$ empenho cênico é bem distribuído entre os dois: Victor assume a figura do artista romântico ou do músico "poeta", enquanto Leonardo é o cantor virtuose que impõe a voz, o corpo e os jogos teatrais com o público. O contato visual com a plateia também é do vocalista. O irmão primogênito sempre mantém os olhos fechados. $\mathrm{E}$ não adianta o apelo gritante das fãs: Victor não abre mão do personagem. Foto: Edy Betty.

${ }^{335}$ Leo Chaves, na véspera de seu aniversário, comemorado no palco do Espaço das Américas, 03 de outubro de 2014. Fonte: do autor (2014). 
Neste capítulo, versarei sobre o desempenho cênico de Victor e Leo nos palcos. Foram registrados quatro espetáculos na capital paulistana:

(A) Terra Country Interlagos (28 de agosto de 2014): lotação máxima para mil pessoas. Em média, o preço do ingresso girava em torno de $\mathrm{R} \$ 40$ a $\mathrm{R} \$ 100$. A casa noturna foi selecionada por ter uma infraestrutura interna mais modesta e pequena, além de ser afastada dos bairros centralizados que abrigam os shows para um público de maior poder aquisitivo.

(B) Espaço das Américas, Barra Funda (03 de outubro de 2014): capacidade para nove mil pessoas. O valor do ingresso estava entre R\$ 150 e R\$ 250. É um espaço privilegiado que recebe artistas consagrados do cenário musical nacional e internacional. Possui uma estrutura técnica sofisticada com palcos tecnológicos, pista de dança, mesas, camarotes e mezaninos ao público.

(C) Citibank Hall, Santo Amaro (13 de dezembro de 2014): comporta sete mil espectadores. Foi cobrado um ingresso de $\mathrm{R} \$ 250$. Estive nesse show, mas não o registrei. Interessava-me encontrar os artistas a fim de acertar a data da entrevista final.

(D) Gravação do DVD Ao Vivo Irmãos, São Paulo, Estúdio Quanta, Vila Leopoldina (28 de janeiro de 2015), 1.200 convidados. Não houve venda de ingressos. A gravação do DVD ao vivo é o carro-chefe da nova música sertaneja. É um negócio atrativo: os artistas têm o coro garantido do público cativo e os contratantes, a venda antecipada de milhares de ingressos. Os assessores podem centralizar a recepção da imprensa, enquanto os produtores "carregam os pianos" do megaevento em um único dia. Especificamente nesse, a entrada foi gratuita, e o show gravado em dois dias em um espaço ínfimo, se comparado aos grandes estádios. Mas foi uma oportunidade imperdível de entender esse novo rearranjo fonográfico.

A pesquisa de campo foi essencial à dissertação. Tive a oportunidade de acompanhar a trajetória dos novos músicos sertanejos e observar a institucionalização do carisma ou de um imaginário afetivo junto ao público espectador. Ademais, permitiu-me uma caracterização espacial dos cenários e bastidores que ambientam a produção cultural do gênero. Aqui, dedicar-me-ei a examinar o empenho cênico dos artistas - a héxis e o apelo corporal ${ }^{336}$

\footnotetext{
336 “A héxis são os princípios interiorizados pelo corpo: posturas, expressões corporais, uma aptidão corporal que não é dada pela natureza, mas adquirida" (BOURDIEU, Pierre. Meditações Pascalianas, 1984, p.133).
} 
mobilizado sob o palco, as indumentárias, as teatralizações encenadas pelas duplas, os diálogos entre palco-plateia - do mesmo modo que ilustrarei tais performances com as fotos coletadas do show. O mapeamento etnográfico foi extenso e exaustivo. Enquanto o gravador portátil captava a ruidosa ambientação sonora, eu me esforçava para narrar (ou "berrar") o que considerava relevante à análise posterior. Confesso que as fãs veteranas me orientavam em meio ao tumulto. Sem a expertise do público feminino, a minha inexperiência não me deixaria ter ido muito longe.

O escritório não acenou tanta disposição. Os acessos que Leonardo Chaves permitiu no primeiro encontro não vingaram. Foi negada a presença nos programas de rádio e TV, a entrada nos bastidores e a participação nos ensaios da banda. A primeira autorização só aconteceu porque o esperei por horas no estacionamento, após o show de Terra Country Interlagos. Gentilmente, o músico disse que colaboraria com o estudo. No outro dia, a assessora de impressa Juliana Chiavassa deu um aval mínimo para o prosseguimento ${ }^{337}$. Ela sempre repetia o mantra: "Victor e Leo são artistas diferenciados". Realmente, há uma dezena de profissionais que os "protegem" da imprensa e das fãs mais insistentes. Elas tentam criar empatia até com os seguranças particulares, Clóvis e Erlei. Porém, o cerco é fechado e isso não seria diferente para um pesquisador.

Para redação deste capítulo, optei somente pela descrição completa da gravação do DVD ao vivo. Os outros shows contêm episódios rentáveis à análise. Porém, em face de uma economia textual, não irei prossegui-los aqui, mas sem hesitar, todos eles amadureceram meu olhar sobre o objeto. Na produção do DVD ao vivo, a relação entre palco-bastidor-plateia esteve mais evidente, bem como a movimentação da equipe técnica envolvida. A presença de artistas convidados trouxe à tona o diálogo de Victor e Leo com outras produções musicais. Não participei do segundo dia de gravação do acústico. Lamento, pois Milionário e José Rico estiveram por lá. Era a última apresentação de José Rico, que morreu em março de 2015. Por fim, Victor e Leonardo Chaves estavam bem à vontade no ambiente intimista do estúdio. Respeitaram as singularidades de um e do outro, ainda que seus personagens entrassem em atrito no palco. Animosidade não faltava entre os irmãos, na música ou no discurso. Souberam aproveitar as longas três horas de intensa gravação para projetarem seus anseios artísticos e pessoais. Para além das cobranças profissionais e afetivas existentes entre os dois, os laços de irmandade e os anos de estrada falaram mais alto.

\footnotetext{
${ }^{337}$ Depois desse episódio, eu recebi ingressos gratuitos em dois shows: Espaço das Américas e Citibank Hall. Na gravação do DVD, deram-me uma pulseira de "profissional da imprensa" para circular pelo estúdio.
} 


\section{A gravação do DVD em São Paulo}

Eu quero ver gol! Gol, gol, eu quero ver show! Gol, gol, contagiou! 338

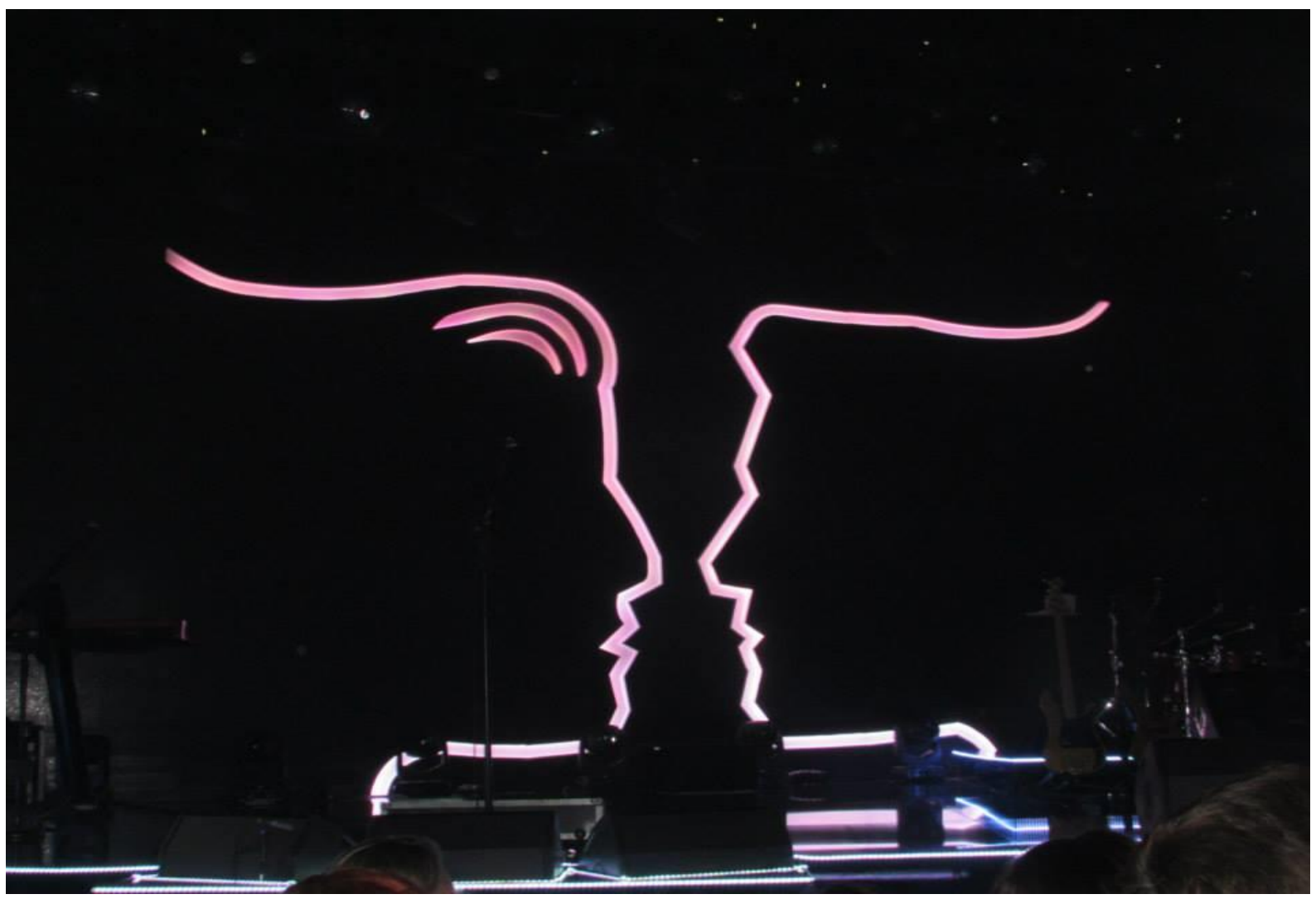

No palco, o desenho do perfil facial dos irmãos foi contornado por luzes fluorescentes de neon. O moderno estúdio tinha uma infraestrutura técnica e operacional sofisticada. Mais de $2.400 \mathrm{~m}^{2}$ divididos em quatro estúdios com $1.000 \mathrm{~m}^{2}$ de áreas de produção. O DVD foi produzido em dois dias de gravações ( 28 e 29 de janeiro de 2015). O cenário foi usado como capa do álbum. Foto: Edy Betty.

A música sertaneja tem como eixo de estabilidade comercial e financeira a venda de ingressos para os shows ao vivo e também para a gravação acústica dos DVD's. É um formato convidativo aos contratantes. Este é o quarto DVD na carreira de Victor e Leo: Ao Vivo em Uberlândia (2007), Ao Vivo e em Cores em São Paulo (2009), Ao Vivo em Floripa (2012) e o DVD Irmãos (2015). Sediar o evento duas vezes em São Paulo, uma vez em Florianópolis (SC) e outra em Uberlândia (MG) foi uma escolha estratégica. São metrópoles que

\footnotetext{
${ }^{338}$ Guerreiro, álbum Viva Por mim (2013) de Victor e Leo.
} 
concentram o maior número de espectadores da dupla, fora a megaestrutura dos ginásios encontrados nessas cidades. Essa é a primeira gravação de DVD da dupla em estúdio. Antes, os eventos aconteceram em estádios e locais que comportavam milhares de pessoas.

O primeiro dia de gravação aconteceu no dia 28 de janeiro de 2015, no Estúdio Quanta $^{339}$ (Vila Leopoldina, zona oeste de São Paulo). O estúdio tinha um espaço intimista e moderno, pista única com capacidade para 800 pessoas, quatro arquibancadas (setores Vips ou camarotes) e acomodações para 400 convidados. A gravação de um álbum acústico em estúdio garante um produto final mais refinado e menos ruidoso. É também um sinalizador de consagração artística à carreira de Victor e Leo que não despontam mais na cena fonográfica como "promessas", mas sim como músicos profissionais de prestígio. Um cenário muito distante daquele encarado pelos novos músicos sertanejos, que se submetem a ambientes mais hostis, palcos amadores e a plateias que procuram diversão e pouco a apreciação de suas canções.

A produção do DVD ao vivo em São Paulo foi um projeto audacioso. Dessa vez, não houve venda de ingressos. O público teve que concorrer em sorteios no site oficial ou nas redes sociais para ter acesso à entrada no evento. Victor e Leo tiveram que se arriscar em divulgar 12 canções inéditas em uma gravação ao vivo. As músicas só “vazaram” à imprensa e às redes sociais a uma semana do evento ${ }^{340}$. As novas canções não tiveram tempo de se popularizar entre as fãs e o coro do público foi bem limitado ${ }^{341}$. O primeiro dia de gravação não foi propriamente "ao vivo", apenas acústico. Adiante, pormenorizarei esses percalços ${ }^{342}$. Assim como no CD Viva por Mim (2013), Leo foi o autor de boa parte das composições, dividindo a tarefa antes restrita somente ao irmão.

Victor e Leo trouxeram seis convidados: Victor Freitas e Felipe e Henrique e Juliano (sertanejos universitários), Lucyana Villar (apadrinhada da dupla), a banda de rock Malta, Wesley Safadão (forró) e o sertanejo tradicional de Milionário e José Rico. A abertura dos portões estava prevista para $18 \mathrm{~h}$, mas foi adiada para $19 \mathrm{~h} 45$. Um pouco antes, o guitarrista

\footnotetext{
${ }^{339}$ Em 2014, foi gravado no mesmo estúdio, o DVD ao vivo do sertanejo universitário Luan Santana.

${ }^{340}$ No dia 20 de janeiro, onze músicas foram divulgadas, exceto Estrada Vermelha (28 de janeiro de 2014).

${ }^{341}$ Salvo as fãs mais antigas que já sabiam de cor as letras inéditas.

${ }^{342}$ Portal IG Sertanejo: Entre atritos e ótima música, Victor e Leo gravam DVD, 30/01/2015.
} 
Beto Rosa e o sanfonista Jander Paiva pararam em frente à fila de espera e fizeram uma “palinha” à capela de Escuridão Iluminada. Os músicos que acompanham a dupla são muito solicitados. As fãs sabem de cor e salteado os nomes de André Campagnani (bateria), Alexandre de Jesus (percussão), Jander Paiva (acordeom), Ricardo Fagundes (violão e guitarra), Thiago Corrêa (contrabaixo) e Beto Rosa (guitarra). Dentre os seis músicos, o último é o que mais atrai os flertes e os gritos do público feminino. Embora minha entrada fosse no portão lateral (o mesmo da imprensa e convidados), aguardei na fila de espera ao lado das fãs.

O show estava previsto para começar às $21 \mathrm{~h}$, mas como o atraso é prática habitual dos artistas, a abertura só ocorreu às $22 \mathrm{~h} 35$. No fim da tarde, aproximadamente cem fãs estavam na fila de espera. Algumas estavam ali desde as $6 \mathrm{~h}$. Todas estavam bem vestidas, com minissaias e blusas decotadas, maquiadas e de salto alto. As moças aparentavam ter entre 18 e 30 anos. Algumas são casadas, porém a maioria é solteira. Em geral, elas residiam nos bairros mais afastados ou nas cidades da grande São Paulo. Algumas eram donas de casa e outras trabalhavam no setor terciário, e se esforçavam para conciliar a intensa rotina de trabalho com as apresentações $^{343}$. Sonhadoras, as jovens compartilhavam seus anseios sobre os irmãos e comentavam os atributos físicos dos ídolos entre si. Rivalidade também não faltava. Havia aquelas que disputavam quem era a mais galanteada por um, a mais abraçada por outro ou demais contos do imaginário do público feminino. As agressões físicas também não são incomuns. Os seguranças têm que apartar as fãs briguentas que saem na mão. Mas ali, eu era o único homem. O público de Victor e Leo é composto majoritariamente por mulheres. Em Terra Country Interlagos, as características eram as mesmas. No entanto, notei uma diversidade de faixas etárias e de gênero nos shows do Citibank Hall e Espaço das Américas. Nesses últimos, homens acompanhados por suas parceiras estavam na plateia. A existência de mesas é outro fator diferenciador, pois tornava o acesso familiar mais convidativo. Porém, se o show é na pista de dança, o reinado absoluto é feminino.

Ingressei no estúdio após a revista dos seguranças ${ }^{344}$ e acompanhei por uma hora a assessora de imprensa Juliana Chiavassa e o produtor musical Paulo. Interessava-me observar como um evento desse porte era estruturado. Para ter acesso livre a todos os setores,

\footnotetext{
${ }^{343}$ O que constata a última pesquisa do IBOPE (2013) sobre o perfil dos consumidores da nova música sertaneja.

${ }^{344}$ A entrada foi controlada por uma lista de nomes, mediante apresentação de um documento com foto.
} 
conferiram-me a pulseira de "profissional da imprensa". Dessa vez, a assessora de imprensa vestia uma camiseta comum com a estampa da dupla. Em outras ocasiões, ela trajava vestidos longos, maquiagem e salto alto. A valorização da beleza feminina é uma espécie de nomos ${ }^{345}$ da música sertaneja. O ethos viril e masculino está presente entre os músicos e os artistas, já a simetria corporal feminina está nas espectadoras e nas profissionais do segmento. No interior da casa, havia um forte esquema de segurança. Clóvis, segurança particular de Victor Chaves, também circulava pelos ambientes, assim como os produtores, os recepcionistas e os bombeiros $^{346}$. No set de filmagem do acústico, os convidados nas arquibancadas e o público na pista se acomodavam em suas posições. Garçons serviam refrigerante, guaraná, água e também cerveja (essa bebida merecerá atenção especial adiante). Porções alimentícias só eram servidas aos convidados e as bebidas eram distribuídas aos dois setores. O ambiente era acolhedor, organizado e sofisticado. O palco (já descrito) trazia os perfis de Victor e Leo cobertos por um degrau em azul fluorescente. Os roadies (assistentes técnicos responsáveis por testar os instrumentos e a acústica do local) já estavam por ali. Os fotógrafos e cinegrafistas contratados pelo escritório circulavam pelos ambientes (no interior do estúdio, deslizavam por um trilho mecânico para gravação e fotografia oficial do show).

Por volta das $22 \mathrm{~h} 20$, o estúdio já estava completo e os músicos da banda tomaram seus lugares. Eis que o produtor Paulo surgiu no palco para dar "alguns avisos" ao público: "Boa noite, sejam bem-vindos! Em nome de Victor e Leo agradeço pela presença de todos vocês. Mas, eu tenho alguns recadinhos para passar. Vocês sabem que é uma gravação de DVD. Eu sei que todo mundo quer tirar foto e filmar, mas eu pediria que evitassem levantar o celular para o flash não interromper a gravação. Está bem? É para ser como se fosse um show normal. Outra coisa: tem espaço ali [referindo-se ao setor à direita da plateia]. Se o pessoal estiver apertado ai [aponta à esquerda e o centro da plateia] tem bastante espaço deste lado. Mais um recadinho, por favor. Como a bebida [alcoólica] está liberada durante o show, mas, por gentileza, não fiquem levantando o copo. Vamos curtir da melhor maneira possível. Eu acho que é um grande presente para todos vocês e um grande show. O que a gente puder colaborar para sair mais bonito ainda será melhor. Em suma, é isso, só vou reforçar sobre o celular, para que não fiquem levantando o aparelho e as mãos, senão a gente vai ter que ser obrigado a parar a filmagem. Para que a gente não fique interrompendo e atrapalhando uma

\footnotetext{
345 “Tais nomos são leis derivadas do uso, do costume, têm validade espaço-temporal e são estabelecidas e sustentadas por quem delas se beneficia: os agentes e as instituições dominantes” (Ibidem, 1984, p.45-46).

${ }^{346}$ A casa contava também com uma equipe médica de bombeiros e duas ambulâncias.
} 
apresentação tão bonita, vamos todo mundo colaborar, está bom? Obrigado e um bom show a todos vocês". As luzes se apagaram, mas Paulo retornou novamente ao palco: "Gente é o seguinte, rapidinho. A gente precisava realmente preencher um pouco mais o lado de lá [à direita] para o DVD ficar bonito. Então, quem está ai no fundão e está um pouco apertado pode ir para lá para ficar uma linha visual legal. A gente precisa da ajuda de vocês. Se tiver lotado vai parecer melhor, se aparecer vazio, o que acontece, as câmeras vão acabar pegando... [não terminou a sentença] Se algumas pessoas puderem vir mais para cá [insiste Paulo para que haja mais pessoas à direita] vai ficar melhor para todo mundo. Outra coisa: vamos fazer um teste de aplaudir. No 1, 2 e 3 faz de conta que é o Victor e Leo que está aqui. Mais forte. Está bom. Obrigado pela colaboração". Alguns minutos depois, pela terceira vez, Paulo terminou os "recadinhos": "Oi, galera, por favor, não coloquem bolsas ou copos no palco, muito obrigado".

"Os recadinhos" do produtor merecem atenção. O DVD da dupla foi anunciado como sendo ao vivo, embora gravado como se fosse um "show normal". Em uma filmagem profissional, o uso de flashes e aparelhos fotográficos daria trabalho ao cinegrafista. Copos plásticos e bolsas também atrapalhariam a movimentação dos artistas. O produtor se refere à gravação como um presente da dupla ao espectador. Tinha outra "cortesia" que o preocupava - a cerveja: “A bebida [alcoólica] está liberada durante o show, mas, por gentileza, não fiquem levantando o copo. Vamos curtir da melhor maneira possível". Esse "curtir da melhor maneira possível" foi um aviso para evitarem possíveis abusos de "bêbados" na gravação. No entanto, a insistência técnica para preencher um lado do auditório soou como um recurso artificial em um show acústico. Primeiro, ele tenta convencer sutilmente "para quem estivesse apertado" à esquerda fosse para o outro lado do estúdio: “Tem espaço ali [à direita] e se o pessoal estiver apertado ai [à esquerda e ao centro da plateia] tem bastante espaço deste lado". Mas ninguém se mexeu. Então, ele retomou em um tom mais enfático: para o DVD ficar "bonito", não poderia deixar um espaço vazio. Ou se "estiver lotado vai parecer melhor" e caso apareça espaço vazio “as câmeras vão registrar". No final, Paulo ainda ensaia um teste de aplaudir: "faz de conta que é o Victor e Leo que está aqui”. Com esses pequenos ensaios teatrais, o produtor tentou treinar o público a "colaborar com esse enorme presente". Tudo para que na edição final o "filme" fosse bem dirigido e comercializado como um produto natural e casual, ainda que houvesse coreografia técnica com o público para que nada saísse do roteiro. Porém, os futuros improvisos e erros viriam dos próprios artistas e não do público. 
Às $22 \mathrm{~h} 35$, os primeiros acordes foram ponteados e com forte aplauso e histeria Leo foi recebido no palco. Vestindo uma regate estampada e calça jeans desfiada, o cantor ostentava os braços bronzeados e musculosos e o contorno das pernas salientes, assemelhando-se às figuras do pop rock internacional. Minutos depois, Victor estaria ao lado do irmão, segurando a guitarra. O compositor trajava uma camisa social preta e uma calça jeans tradicional. A música de abertura da apresentação foi Na Linha do Tempo ${ }^{347}$. No visor, sob a face dos dois irmãos em formato de perfil, imagens da carreira foram projetadas em uma tecnologia de alta qualidade. Encerrada a música de abertura, Victor e Leo passaram para o novo repertório. Eu estava bem ao fundo do estúdio e notei à frente do palco um monitor teleprompter (coberto por uma cortina) com as letras das canções. O letreiro só despontava as músicas inéditas (exceto em Borboletas e Sou Guerreiro, que teve a participação do roqueiro Bruno Boncini). O recurso seria usado principalmente pelos convidados. Sabor dos Ventos (2015) foi a segunda faixa executada. Victor ainda optou pela guitarra, mas o violão em cordas de aço ganharia paridade adiante. $\mathrm{O}$ coro dos espectadores ficou mais tímido e fraco. Se até os artistas não memorizaram as novas letras, as entusiastas muito menos. Logo, Victor tomou a palavra: “Teoricamente, agora, seria um 'boa noite'. Teoricamente sim, como foi combinado. Porém, antes de dar boa noite, eu queria dar um beijo numa pessoa aqui”. Os irmãos se abraçaram no centro do palco. Leo aproveitou e deu uma batidinha no bumbum do irmão e a plateia soltou "eu também quero". Emocionado, concluiu: "Fica sendo este o meu 'boa noite".

O compositor retomou a posição, agora usando o violão e prosseguiu com Escuridão Iluminada. Com uma letra pouco usual no estilo musical da dupla, eis que dois pares de dançarinos de tango apontaram no palco. Porém, a apresentação parecia estar travada. Rapidamente, Leo explicou: "Essa música especialmente a gente vai gravar amanhã junto com o Wesley Safadão [vocalista da banda nordestina de forró Garota Safada]. Hoje, ele não pôde estar conosco na gravação. Então, a gente fez hoje com vocês, mais para ensaiar mesmo. Amanhã é para valer. Hoje já está tudo avacalhado mesmo. Mas, vamos continuar. O show não pode parar!”. Na realidade, outros tropeços acompanhariam a gravação do DVD. Pelas reações do empresário, da assessora de imprensa, dos produtores musicais e dos intérpretes, a gravação não estava caminhando bem (isso na terceira faixa). Ao soltar um "hoje já está tudo avacalhado mesmo", Leo apontou seu descontentamento com Wesley Safadão e também com os rumos da gravação. Sagaz, o experiente vocalista exploraria outros substitutos: o falsete na voz e a volúpia do corpo.

\footnotetext{
${ }^{347}$ Música de trabalho de 2014, do álbum Viva Por Mim (2013).
} 
Em janeiro, a dupla lançou o terceiro videoclipe da carreira: Caminhos Diferentes. Na gravação do DVD, as cenas do clipe eram exibidas nos telões e o público podia acompanhálos encorpando o coro. Não demorou e Victor reclamou da afinação do instrumento: "Esse violão é sempre um sucesso. Vocês gritam 'lindo, lindo e lindo' e ele não sabe agradecer. Agradeço por ele. De nada”. Leo aproveitou e entrou no camarim para a primeira troca de roupa, enquanto o outro foi deixado sozinho no palco. Se o cantor tem bom controle da voz durante o canto e sabe qual figurino que lhe cai bem, Victor usa e abusa da arte da persuasão: "Hoje, as pessoas são de vários lugares. Vieram de vários lugares para trazer essa energia. Obrigado pela presença de cada um de vocês, por terem saído de suas casas para dividirmos isso. Saibam que as pessoas que assistirem a esse DVD um dia, a partir de uma pessoa, esse DVD passa a fazer sentido. Toda vez que alguém se emocionar, esse DVD faz sentido. Se daqui a muitos anos alguém tiver acesso a esse DVD e sentir a nossa energia, ele vai fazer mais sentido ainda. Porque podemos passar. Mas, a nossa energia não passa. É de verdade que a gente agradece a presença de cada um. Isso daqui é um encontro de pessoas que aprenderam a nossa filosofia, ideológica sonora e qual é a nossa ideia artística para este mundo de Deus. É óbvio que a vida da gente passa muito rápido. E quanto mais ela vai passando, mais a gente sente isso. De forma que só fará sentido se a gente fizer algo por amor. O que fazemos aqui é por amor a vocês. Então, muito obrigado de coração”.

Victor sabiamente encena o poeta. Singulariza sua arte em energia, já que "isto não passa". O compositor personifica essa aura romântica do artista puro para convidar os seus pupilos: "a aprenderam nossa filosofia, ideológica e sonora" lhes ensinando: "qual é a nossa ideia artística para esse mundo”. Essa emocionalização da arte adoça os corações das fãs. O dueto de irmãos, as narrativas caipiras, o sotaque mineiro e a beleza estética garantem à adesão do grande público. Engana-se quem pensa que os "bons moços do interior" atuam da mesma forma: eles se complementam. Um abusa da sensualidade viril em seus jogos cênicos. O outro carrega o semblante afetivo e emocional do moço já grisalho que tem o "dom" das palavras do coração, o artista que frui enquanto toca o violão de olhos fechados e o homem que retraduz sua solidão em belas composições. Esse imaginário pactuado com as fãs justifica a espera e o longo caminho até vê-los ou abraçá-los. Uma verdadeira maratona.

Assim como nos outros shows, novamente, trouxeram aos palcos "a nova promessa da música sertaneja", a cantora apadrinhada Lucyana Villar. Ela participou da canção Sem Limites para Sonhar ao lado de Leonardo, cantando trechos em inglês com uma batida do 
country music norte-americano. Lucyana estava de visual novo: dreads nos cabelos. Trajava uma minissaia jeans, botas de cano alto e uma miniblusa estilo safari que ressaltava o belo contorno de seu corpo. Geralmente, ela é quem encena os modões nas apresentações ${ }^{348}$. Mal a música acabou, Leo fez outra pontuação: “A gente vai ter que repetir essa música. Vou trocar meu fone de ouvido, porque o lado direito pifou". Certas faixas foram regravadas mais de uma vez. Não consegui identificar se houve falhas técnicas do estúdio ou problemas com afinação instrumental dos músicos. Suponho que essa repetição nas performances fosse pelo pouco tempo de ensaio do álbum inédito. Seja como for, a gravação em estúdio não saiu como o esperado. Embora acústico (com presença de plateia), o DVD tinha pouco de um show ao vivo sem interrupções, como anunciou o produtor em seu início . O incômodo de Leo era nítido. Então, Lucyana interpretou uma despedida, agradeceu ao público e classificou seu novo visual de "maloqueira". Os dreads que a moça exibia são comuns entre os descendentes africanos da América. Ainda assim, o termo "maloca" ou "maloqueira" não me pareceu preconceituoso, e sim uma expressão equivocada para "bagunçada" ou "alternativa". Tudo seria repetido. Nossa Trilha também contou com a participação da moça. A iniciante agradeceu, mas Victor Chaves entregou: “Acho que a gente podia repetir". Leo acrescentou: "Aliás, a gente podia repetir todas as inéditas. Vocês também acham? Agora é para valer. A outra foi ensaio". De fato, a gravação estava truncada. A réplica de Leo soou como uma resposta irônica ao pedido do irmão. Depois de fazer dois agradecimentos iniciais e duas despedidas, finalmente a cantora despediu-se do público "agradecendo a oportunidade".

O show prosseguiu com a música Noite Fria. Desde então, Leo Chaves passou a abusar do falsete (quando o registro natural da voz é alterado). A tensão em suas cordas vocais era nítida nos telões tanto quanto o seu desgaste físico. Nos últimos anos, ele tinha minimizado o uso do falsete e do vibrato (tremor da voz). De um modo geral, essa foi uma prática adotada por todos os sertanejos universitários, numa tentativa de deixar o som mais acústico e menos estridente. Essa apropriação do cantar foi comum ao sertanejo romântico dos anos 1990 (Zezé Di Camargo é o maior representante). O cantor enxugou-se na toalha,

\footnotetext{
348 Trecho do show em Terra Country Interlagos: Lucyana Villar cantou alguns clássicos do sertanejo ao lado dos irmãos: "A energia daqui é realmente diferente". A apadrinhada seguiu com a moda de viola Liguei Pra Dizer que Eu te Amo, de Alan e Aladin (1987), Amor de Primavera, de Di Paullo e Paulino (escrita por Raul Torres e José Rielli): "É muito pé no barro, é muito bom”. Leonardo diz que há um ano e meio estão produzindo um disco juntos, que será lançado em breve: "Música pura, saída diretamente da alma e do coração", acrescenta a cantora sertaneja. E continuam com Milionário e Zé Rico, Vontade Dividida (1991). Leo: “Agora, Chrystian Ralph para lembrar os nossos bons tempos de bares". Victor hesita, parece não lembrar mais o tom da música. Leonardo insiste "Bora, bora, puxa aí, negócio bom é improvisado" e pede para um membro da banda ajudar Victor. E sai: Esse amor me mata (1995). Fonte: do autor (2014).
} 
enquanto Victor conversava com os membros da banda sobre a má afinação do violão. Leo saiu e entrou no palco, agora, vestido com outra regata estilizada para cantar Sou Guerreiro, música tema da Copa Mundial FIFA (2014). Para encenação, seis crianças (apenas uma branca e as demais pardas ou negras) vestidas com a camisa do Brasil subiram ao palco, chutando bolas de plástico coloridas à plateia, que se contorcia para pegá-las: "Esse é o esporte brasileiro. Que a gente possa ter um pouco mais de incentivo para que nosso país tenha um esporte nacional, independente do futebol ou não. Esporte é educação para as crianças do nosso país. Além disso, dedico essa música para meus dois filhos [Matheus e Antonio] que não estão aqui, mas são apaixonados por essa música. Vocês estão representando meus filhos e todas as crianças do Brasil, muito obrigado". Terminado o discurso e a teatralização, Leo fez menção à possibilidade de repetir a música, como se alguém tivesse pedido para fazer "mais uma vez". Claro que ninguém pediu: era apenas uma desculpa para regravação. Então, os produtores pediram para que o público "devolvesse" as bolas arremessadas. Novamente, tudo recomeçava. Foi um episódio embaraçoso: a fala de que "aquelas crianças representam meus filhos e todas as crianças do Brasil" não atenuou o componente racial dos atores mirins. Sinceramente, reproduziu mais um estereótipo do que a valorização do esporte supostamente nacional.

A gravação do DVD continuou com $15^{\circ}$ andar e Leo Chaves fez sua terceira troca de roupa: vestindo uma camisa preta social. Agora, quem subiu ao palco foram os convidados Victor Freitas e Felipe. Os irmãos gêmeos de 23 anos são de Uberlândia (MG) ${ }^{349}$ e fazem um som mashup ${ }^{350}$ (mistura de pop internacional e música sertaneja) que Victor e Leo apreciam. Aliás, o sertanejo "místico" da dupla aceita de bom grado confluências com o rock e o pop mas não com o funk. Como declararam anteriormente: "funknejo é como misturar café com gasolina”. Juntos cantaram Vai me Perdoando. Dessa vez, foi a plateia que pediu "de novo" 351 . Em dezembro de 2014, o selo Som Livre lançou o CD Perfil - coletânea com as músicas famosas na carreira de Victor e Leo. As faixas: Caminhos Diferentes e Como Eu Amei foram as únicas inéditas. Na gravação do DVD, elas foram apresentadas pela primeira vez ao vivo. O coro da plateia estava garantido. A segunda canção foi acompanhada por solos de guitarra de Victor e pelos falsetes do irmão. A voz grave de Leonardo alcançava notas tão agudas que

\footnotetext{
${ }^{349}$ Cidade atual de Victor e Leo.

${ }^{350}$ Universo Sertanejo: Victor Freitas e Felipe e um “mashup” elogiável, 28 de julho de 2014.

${ }^{351}$ Pela quarta vez consecutiva, uma música seria regravada para o DVD. O episódio se repetirá até o final do show.
} 
era quase impossível reconhecê-la. "Como já estava tudo avacalhado", Leo optou pelo canto operístico em alto vibrato ${ }^{352}$ e assumiu o papel do artista virtuose, exaltando todo seu domínio técnico. Próximo à meia-noite, observei uma leve dispersão do público. Não conseguiam mais disfarçar o cansaço e a frustração. Se no início as bebidas alcóolicas foram servidas a todos, agora seria reservada apenas aos convidados. Mais tarde, a cerveja voltou a circular na pista comum. Estranhei tal tipo de bebida em uma apresentação dos irmãos. Tanto nos shows quanto nas redes sociais, Leonardo sempre exibiu a malhação, a prática de esportes e o apreço pelo bem-estar do corpo. A cerveja foi fornecida pelo estúdio, o que não isenta a responsabilidade do escritório, uma vez que o estúdio contratado cumpre a lista dos itens exigidos e pagos pelo escritório da dupla. Na saída, havia um esquema de frotas de táxis. Logo, Victor criaria outra polêmica.

Por enquanto, o show seguia com Simples Assim. Leo pediu a palavra: "Antes da próxima música, eu só queria fazer um comentário básico. Essa próxima canção é minha e de um companheiro antigo de parceria de composição e de música Marcelo Martins, do dueto João Lucas e Marcelo. Obrigado pela parceria”. 10 Minutos Longe de Você foi conduzida com a dupla Henrique e Juliano, a terceira participação de convidados na noite. Seria a quarta, se Wesley Safadão não tivesse faltado. Nessa canção, a plateia tinha a letra na ponta da língua. Henrique e Juliano são conhecidos no circuito da música sertaneja universitária de Palmas (TO). Músicas como Vem Novinha, Recaídas, Mistura Louca, Não Tô Valendo Nada e Gordinho Saliente atraíram mais de 25 mil pessoas no Estádio Nacional de Brasília Mané Garrincha. A temática festiva dos irmãos fez sucesso entre os jovens. A exibição mal acabou e o perspicaz cantor fez uma "nova proposta": "Essa aqui quem vai escolher se quer repetir são vocês. Para mim e para o Victor, foi tudo bem. Quem manda aqui é vocês". Claro que aceitaram. O público tinha que aplaudir como se fosse a primeira execução. Até os diálogos no palco eram repetidos. Parecia gravação de novela. Os irmãos tinham pequenos atritos: Leo pedia para acelerar o ritmo da gravação e Victor convidava os cansados a irem embora já que o ritmo parecia "travado". Então, o compositor pediu uma pausa breve de cinco minutos. Às 00h15, com quase duas horas de gravação, houve uma segunda dispersão, dessa vez maior. Leonardo notou. Enquanto o irmão e os membros da banda iam para o camarim, o hábil e

\footnotetext{
${ }^{352}$ Ivan Vilela explica: "Vibrato é o tremor da voz. Na verdade, na ópera, o cantor tem o desenvolvimento, a partir da Renascença do aparelho vocal. Ele precisa ganhar potência para competir sonoridade com a orquestra. Há um trabalho de impostação da voz de modo que ela se potencialize. Agora, o vibrato da música sertaneja pode ser chamado de vibrato caprino - um tratamento quase depreciativo - porque o som é quase de um carneiro. Então, um canto operístico em alto vibrato é a potencialização da voz seguida de tremulação". Fonte: do autor (2014).
} 
experiente vocalista soube chamar a atenção: sozinho e à capela soltou a voz: "Pensando bem, eu gosto mesmo de você. Pensando bem quero dizer que amo ter te conhecido". A música Amigo Apaixonado foi uma das responsáveis pela popularização nacional da dupla, em 2007. Se o irmão é "poeta", Leo é engenhoso. E não parou por ali. Cantou sem acompanhamento instrumental Fada (2007), Lembranças de Amor (2007), Cuidador de Fogo (2007) e Meu Eu em Você (2007). A banda estava voltando e, então, ele finalizou a sessão com uma música clássica do repertório: Vida Boa $(2006)^{353}$.

Eis que Victor, vestindo uma camisa branca e um chapéu estilo panamá branco (visual comum entre os pioneiros do samba carioca), surgiu com um charuto na boca na ponta do palco. Nas primeiras tragadas, o compositor justificou o consumo do tabaco: "Me sinto melhor do que você [olhando para o irmão com semblante de descontentamento]. Um charutinho de vez em quando não faz mal. Eu estou entre amigos. Eu posso fazer isso, pois não estou no meio do meu público, estou com meus amigos. É uma coisa que eu faço em casa. Como estou me sentindo em casa, eu faço isso junto de vocês". Leo, que estava mudo até então, rebateu o irmão: "Fica calma negodu, que aqui ninguém tem direito de julgar ninguém, fica tranquilo, está tudo certo. Isso é até bom. Dá um clima”. No entanto, a expressão facial de Leonardo indicava sua total desaprovação. Tanto que ele já franziu a testa quando o irmão entrou soltando fumaça. A presença do charuto ${ }^{354}$ estava longe de ser um consenso ou um objeto cênico coreografado por ambos. A encenação de rebeldia de Victor soou como ato de reprovação frente aos rumos musicais da dupla. Se comercialmente o selo Som Livre é vantajoso à carreira dos dois, o compositor parece não aprovar o atual rearranjo artístico. Ao dizer "Me sinto melhor do que você", as palavras de Victor Chaves refletiram essa rejeição da nova imagem do irmão. A lei antifumo (2013) proíbe o consumo de tabaco em locais fechados. A multa pode chegar à cifra de um milhão e meio de reais. Mas, não fiquei sabendo se ele ou o estabelecimento foram punidos.

\footnotetext{
${ }^{353}$ As faixas Tem Que Ser Você, Fotos, Borboletas, Fada e Vida Boa é o quinteto que nunca pode faltar, por mais que as novas músicas vão surgindo, e também se consagrando, o público sempre pede pelas canções que os tornaram ícones da nova música sertaneja. Nos shows, existe um consenso entre eles: a cada ano, há um novo álbum com turnê repaginada. À medida que as canções se popularizam (ao longo dos anos, umas "pegam mais que outras"), tornam-se uma espécie de repertório clássico que não pode faltar.

${ }^{354}$ A polêmica do charuto foi anterior à gravação do DVD. Em novembro de 2014, Victor recebeu críticas por publicar uma foto fumando tal tabaco na rede social Facebook. Um charuto considerado "suspeito" pela grande mídia. O compositor sempre foi recatado e evitava que sua vida particular fosse invadida pela imprensa. É a primeira polêmica pública de sua carreira. Na foto, há uma mão feminina referida como "boa companhia" e uma legenda provocativa. Dezenas de fãs se indignaram com a postura excêntrica do músico, pois eles têm um grande público infantil. $\mathrm{O}$ artista gostou da repercussão. Dois meses depois, mostrou sua pequena rebeldia em um show ao vivo.
} 
Em seguida, o tal charuto foi retirado por um membro da produção. Então, sentaramse à beira do palco com mais dois músicos. Leo continuou: "Olha só Catatau [diretor artístico do DVD], nós decidimos fazer esse DVD aqui um pouco mais intimista [se comparado com o DVD Ao Vivo Em Floripa, vencedor do Grammy, de fato, Leonardo foi coerente na escolha do adjetivo "intimista"], para que realmente a gente pudesse reunir aquelas pessoas que nos acompanham nestes sete anos pelo Brasil inteiro, nas madrugadas, e são vocês que estão aqui. Então é isso. São sete anos, quase oito". Victor usando os nove dedos da mão o retificou: "São nove anos, você errou por dois". O compositor assumiu a primeira voz em Tempo de Amor. Apesar de inédita, o público fez coro, e claro, a regravaram: "Vamos cantar de novo, para vocês cantarem para seus amores”. Logo, os irmãos anunciaram que fariam um crunch (algo informal) para cantar Momentos. Antes, Victor citou o avô: "Eu e o Leo tivemos uma convivência muito grande com nosso avô materno, nosso avô Tonico. Ele falava muito pelo silêncio. Hoje, eu tive um sonho com ele. Ele estava numa casa bem velhinha. Chegava uma senhora que não a conheço e me chamou pelo nome: 'vem aqui Victor que ele chegou'. Eu não entendi, mas quando passei para outra salinha eu o vi. Eu não acreditava que estava o revendo. Faz muito tempo que ele passou para o lado lá. Mas, ele me abraçou bem apertado e confortavelmente. Acordei emocionado com a ideia de que o silêncio fala mais do que mil palavras. Quando ele é sagrado e bem intencionado. Daí, veio essa música [Momentos] umas 04h30 da manhã. Pensei naquilo tudo para expressar o sentimento desta música e, às 08h da manhã, eu já estava indo dormir com isso pronto”. Emocionado, Victor erraria duas vezes o tom dos acordes do violão. Dessa vez, a plateia pediu bis. O músico mineiro gosta de enaltecer sua origem social e a influência cultural do avô Tonico. Esse ethos de estima pelo "silêncio sagrado" ou pelo "silêncio que fala mais do que mil palavras" é uma espécie de dispositivo $^{355}$ cognitivo de reprodução de certas categorias sociais em que Victor foi socializado na esfera familiar ${ }^{356}$. Do mesmo modo, isso se repete na valorização da estética da simplicidade descrita na "casa bem velhinha". E assim, o compositor retraduz os valores sociais em sua arte: "O silêncio representa o sentimento desta música”.

\footnotetext{
${ }^{355}$ O conceito de habitus ou dispositivo é definido por Pierre Bourdieu como um: "Sistema de disposições duráveis e transferíveis que, integrando todas as experiências passadas, funciona a cada momento como uma matriz de percepções, apreciações e ações, e torna possível a realização de tarefas infinitamente diferenciadas, graças às transferências analógicas de esquemas que permitem resolver os problemas da mesma forma e graças às correções incessantes dos resultados obtidos, dialeticamente produzidas por estes resultados" (BOURDIEU, Pierre. Esboço de uma Teoria da Prática, 1983, p.261).

356 “Assim, as disposições associadas a certa origem social não se consumam senão especificando-se em função, de um lado, da estrutura dos possíveis que se anunciam através de diferentes posições e tomadas de posições de seus ocupantes e, do outro lado, da posição ocupada no campo que (através da relação com essa posição como sentimento do sucesso ou do fracasso, ele próprio ligado às disposições, portanto, à trajetória) orienta a percepção e a apreciação desses possíveis: as mesmas disposições podem conduzir, assim, a tomadas de posição estéticas ou políticas [...] Os habitus, enquanto sistemas de disposições, só se realizam efetivamente em relação com uma estrutura determinada de posições socialmente marcadas [...]" (Ibidem., 1996, p.299).
} 
Os músicos retomaram o centro do palco e Victor substituiu o violão pela guitarra elétrica. Os produtores correram para retirar os artefatos cênicos do tal crunch realizado à beira do palco. Leo assumiu que houve falhas, mas afirmou: "definitivamente, não vamos repetir três vezes Tempo de Amor e Momentos". O compositor reconheceu o apelo inicial do cantor que: "A gente deveria acelerar, pois está quase terminando". Os irmãos sabiam que não poderiam repetir os mesmos tropeços no segundo dia de gravação. Não é para menos: não era um ensaio em estúdio, mas a gravação de um DVD acústico vendido como "ao vivo". Leo trocou o blazer por uma regata: "É o seguinte: a gente resolveu fazer esse show junto de vocês, porque são as pessoas que nos acompanham de madrugada a madrugada, durante esses sete, oito ou nove anos, assim como meu irmão disse. Não interessa. Interessa é que vocês esperem mais madrugadas e noites para ouvir a gente cantar para vocês. O que interessa mais ainda é que vocês não estejam cansados ainda. É muita energia nesta porra aqui. Quem estiver cansado pode ir embora. É por isso que a gente resolveu convidar vocês. Isso não vai para o DVD, ok? [o palavrão]". Essa retórica de "quem estiver cansado pode ir embora" não é ocasional. Em Terra Country Interlagos, ele repetiu esse discurso excêntrico de desprezo ao cansaço do público $^{357}$. Então, cantaram sucessos nacionais como Primeiros Erros do Capital Inicial e Vamos Fugir da banda mineira Skank. O vestuário (regata e calça jeans desfiada) e os trejeitos contorcidos do cantor lembrava o empenho performático da banda de rock Rolling Stones. Em seguida, receberam a quarta e última apresentação convidada para o DVD: a banda roqueira Malta. Leo fez dueto com Bruno Boncini, em Anjo ou Fera. O uso intenso do falsete deixou sua voz quase irreconhecível. Acompanhado por quatro guitarras, o show sertanejo se transformou em rock. No primeiro DVD da carreira, Ao Vivo em Uberlândia, a imagem do cantor era outra: o cabelo curto e bem cortado, barba feita, calça jeans tradicional e uma camisa social. O selo Som Livre o ajudou a reelaborar outro personagem: o corpo definitivo e bronzeado, regatas provocativas, calças desfiadas, a barba por fazer, o cabelo desgrenhado, chapéu e óculos escuros estilo mariachi, crucifixos e outros assessórios. Em cena, o intérprete folk da dupla sertaneja Victor e Leo. Para variar, o "tom" não saiu certo.

\footnotetext{
${ }^{357} \mathrm{O}$ vocalista se mostrou contrariado com a equipe técnica da casa. Há todo um protocolo no encerramento, não sendo aceitável a reprodução musical de concorrentes, enquanto o artista tece as palavras de agradecimento e ouve o clamor do público. Ao dizer as palavras finais para o público, sai no som de fundo da casa "o, o, o uouo", música Flor, de Jorge e Mateus. Leonardo assume a personalidade do ator protagonista: "O, espera aí, mais uma, parceiro! Uma coisa muito importante para se aprender. É muito cedo ainda, e não sei se foi aqui [a equipe técnica da própria casa]. É um desrespeito grande com a plateia. Antes que um artista se despeça da plateia, não pode botar som. Não pode pôr! E o artista vai cantar mais uma, porque a plateia está boa demais. Se a palma da plateia não saiu do palco, não põe o som não, senão a pipoca estoura. Só por isso nós vamos fazer pelo menos mais duas". Não satisfeito continua: "Alguém está com pressa de ir embora para casa aí? A gente vai até amanhecer, quem tiver com sono pode ir embora para casa, a gente vai até o dia nascer". O seu orgulho não parecia cansado: "Mais uma, ou mais duas?". Fonte: do autor (2014).
} 
Bruno fez um desabafo: “Que letra difícil bicho. É muito poeta para pouca pessoa”. Anjo ou Fera foi regravada três vezes. A banda Malta recebeu outro convite: cantar Borboletas (canção famosa da dupla). As fãs gritavam freneticamente a letra, acompanhando os ídolos. Claro, o público pediu "mais uma". Por fim, Leo teceu seus agradecimentos próximos ao encerramento: "A gente queria aproveitar e agradecer aos colegas da gravadora: Som Livre, muito obrigado". O primeiro dia de gravação do DVD estava chegando ao fim. Ainda, por dez minutos, os irmãos ficaram conversando com os produtores à beira do palco. Saiu Conheço pelo Cheiro, música com um ritmo mais próximo à rancheira mexicana, e Leo colocou óculos escuros e um chapéu estilo mariachi. Fecharam o show com a música de trabalho de 2014: Tudo com Você (que ficou por treze semanas consecutivas como a mais tocada nas rádios brasileiras). Às $2 \mathrm{~h}$, despediram-se com um "muito obrigado, galera, boa noite" e saíram abraçados $^{358}$.

É importante ressaltar que o monitoramento de Victor e Leo foi feito entre julho de 2014 a janeiro de 2015. Em seis meses, estive em quatro shows dos irmãos mineiros em São Paulo. Mas, sem hesitar, o registro da gravação do DVD ao vivo foi um marco determinante para os rumos da pesquisa. Não é à toa que decidi trazê-lo no texto, em vez de descrever os shows tradicionais. Desde a disseminação digital das músicas e da distribuição pirata do mercado ilegal, são os shows e os DVD's ao vivo que garantem os lucros extraordinários à música sertaneja. Com a exceção desse, com entrada gratuita (conferida por sorteios e aos convidados), nos demais, os ingressos são cobrados e as gravações arrastam milhares de espectadores para os estádios brasileiros. Ademais, a gravação de um DVD ao vivo tem outra estratégia: a aproximação do público com o artista por meio do formato acústico. De 2005 para cá, a produção fechada em estúdio foi praticamente abandonada pelos novos artistas sertanejos $^{359}$. Na gravação do DVD acústico de Victor e Leo, pude observar a relação dos artistas com os empresários, os produtores, os assessores, os patrocinadores e, sobretudo, com o público - tudo isso ao mesmo tempo e em um único ambiente. Mas é importante destacar que o sucesso no mercado do show business não atua sozinho na promoção comercial da música sertaneja. Tal estilo só pôde se manter ascendente graças às apropriações de outros gêneros musicais (pop, rock, country music etc.), tanto na linguagem instrumental quanto no

\footnotetext{
${ }^{358}$ No total, foram $3 \mathrm{~h} 25$ de gravação, 27 músicas executadas (9 regravadas), somando 36 canções apresentadas: 12 faixas inéditas (exceto Estrada Vermelha, cantada no dia seguinte com a participação de Milionário e José Rico), duas composições do CD Perfil (dezembro de 2014); duas de bandas nacionais; quatro músicas do álbum: Viva por Mim (2013) e sete cancioneiros clássicos da dupla.

${ }^{359}$ Essa é a realidade também para artistas de outros gêneros nacionais.
} 
desempenho cênico. No caso de Victor e Leo, ainda nos primeiros anos de reconhecimento midiático, o cancioneiro manteve alguma resistência tradicional. A ida para o selo Som Livre "modernizou" até mesmo as narrativas das canções. A mudança na imagem pública de Leonardo Chaves é o índice maior dessa translação. Um comentário do professor Ivan Vilela me chamou a atenção: a música sertaneja, enquanto um gênero com propriedades singulares, praticamente não existe mais. Se existe, está fragmentado em algumas letras de canções atuais. E o compositor Victor Chaves é o maior exemplo de algum domínio de "resistência cultural", mesmo que apenas no discurso.

A música sertaneja universitária ou a nova música sertaneja teve que adaptar-se aos estilos do rock e pop para ganhar novos públicos urbanos e manter-se crescente na indústria fonográfica. Entretanto, essas estratégias de reconversão social não estão restritas somente à atualidade do ritmo. O processo é mais antigo: Raul Torres trouxe as harpas e as guarânias mexicanas no final dos anos 1940 à música caipira; Milionário e Zé Rico, Leo Canhoto e Robertinho e Sérgio Reis incorporaram o rock da Jovem Guarda, modernizando a música sertaneja dos anos 1970; os artistas do sertanejo romântico dos anos 1990 trouxeram o country music e popularizaram o gênero, conquistando até mesmo o público urbano. Esse rearranjo na música rural não é um exemplo isolado ao Brasil - o mesmo aconteceu em países como os Estados Unidos. Em 1978, o sociólogo norte-americano Richard Peterson concluiu em seu estudo The Production of Cultural Change: The Case of Contemporary Country que, entre os anos 1960 e 1970, o gênero country teve que enfrentar uma modernização da roupagem sonora. Sendo o gênero rural do país, o country teve que incorporar as sonoridades do rock e pop para manter-se na indústria fonográfica norte-americana. Lá, o country rural se transformou em um folk urbano. A trajetória social dos irmãos exemplifica bem esse paradoxo entre modernização e tradição no novo cenário cultural da música sertaneja. Essa espécie de "resistência simbólica" defendida nas composições iniciais de Victor cede espaço, pouco a pouco, às temáticas do pop internacional. Leonardo prontamente abraçou o novo espetáculo. Fernando e Sorocaba não só aceitaram o formato atual como estão empenhados em ampliá-lo. Sorocaba, o artista/empresário sertanejo, soube como ninguém garantir boas doses de entretenimento ao show. A seguir, seguem as imagens que foram fotografadas ${ }^{360}$ na gravação do DVD. Deixei para trazê-las à parte do corpo do texto, embora o registro fotográfico esteja articulado com a análise sociológica feita durante todo o capítulo.

\footnotetext{
${ }^{360}$ Colaboração de Edy Betty.
} 


\section{Victor e Leo ao vivo e em cores}

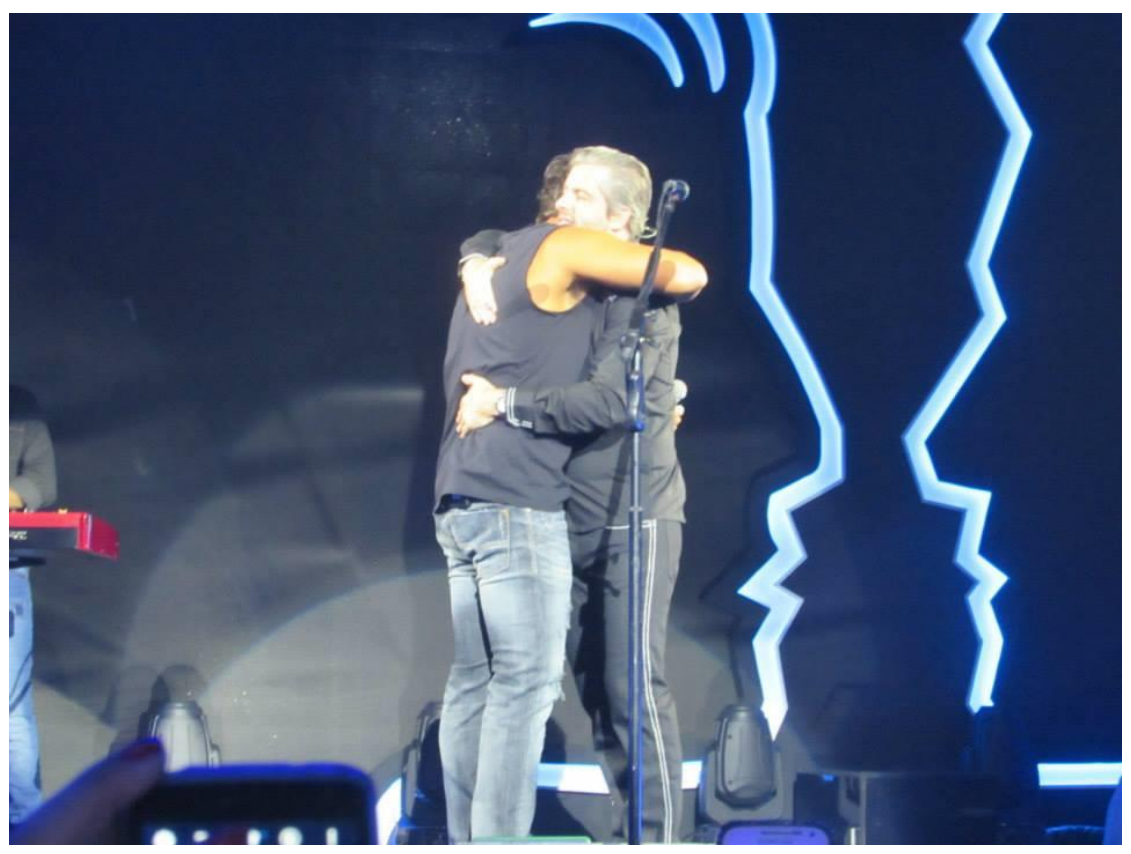

Victor e Leo selam um abraço na abertura do DVD. A composição coreográfica foi estratégica: a posição corporal dos dois é acompanhada pela ilustração facial do cenário. O companheirismo musical e familiar é sempre prezado publicamente. Aliás, o dueto entre os irmãos garante a empatia e a adesão de um público mais tradicional. É também uma das marcas registradas da história social da música sertaneja. Cornélio Pires foi o responsável pelas primeiras gravações em CD do gênero e o sistematizador desse formato. Foto: Edy Betty.

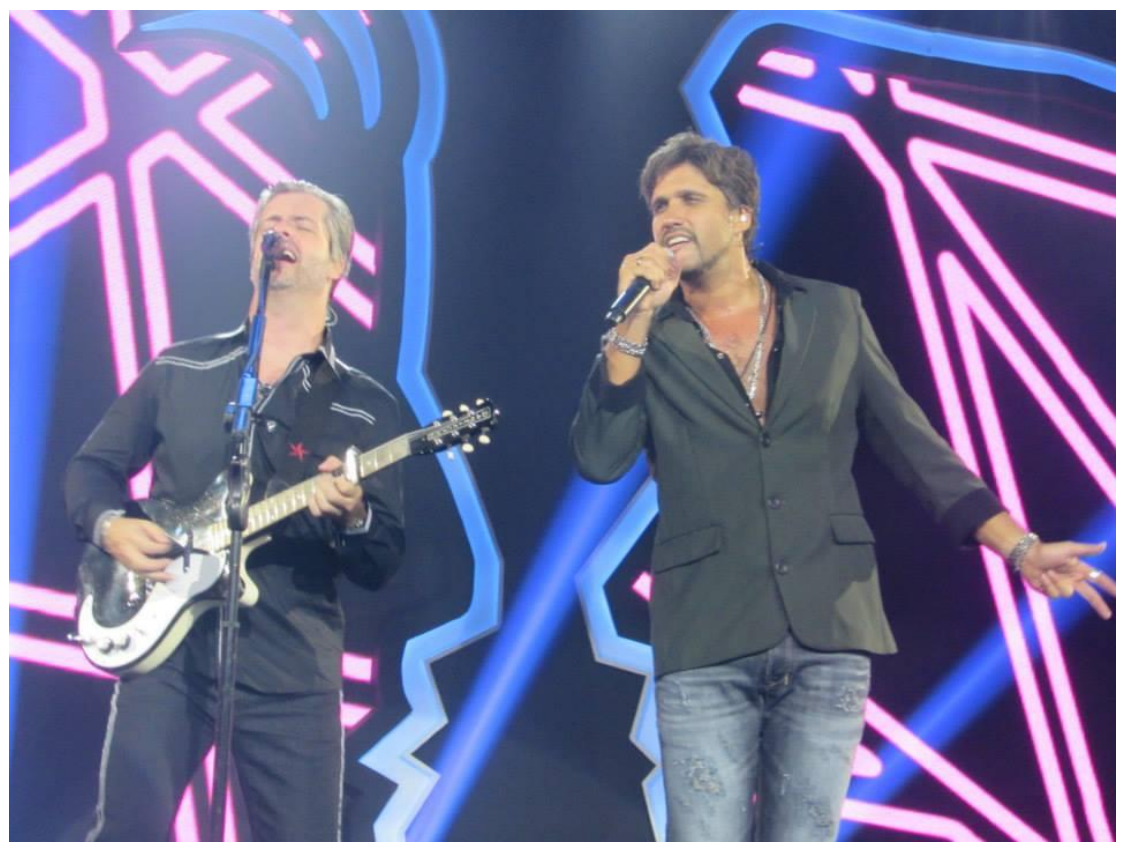

Victor na guitarra (à esquerda) e Leo nos vocais (à direita). A beleza é um capital bem investido na carreira artística. A estética europeia é herança paterna: são bisnetos de dinamarqueses e italianos. Se os cabelos grisalhos do compositor lhe auferem "charme", o irmão tem outros atributos físicos apreciados pelas espectadoras: Leo é alto, mede 1,94 m e tem um corpo atlético e bronzeado. Foto: Edy Betty. 


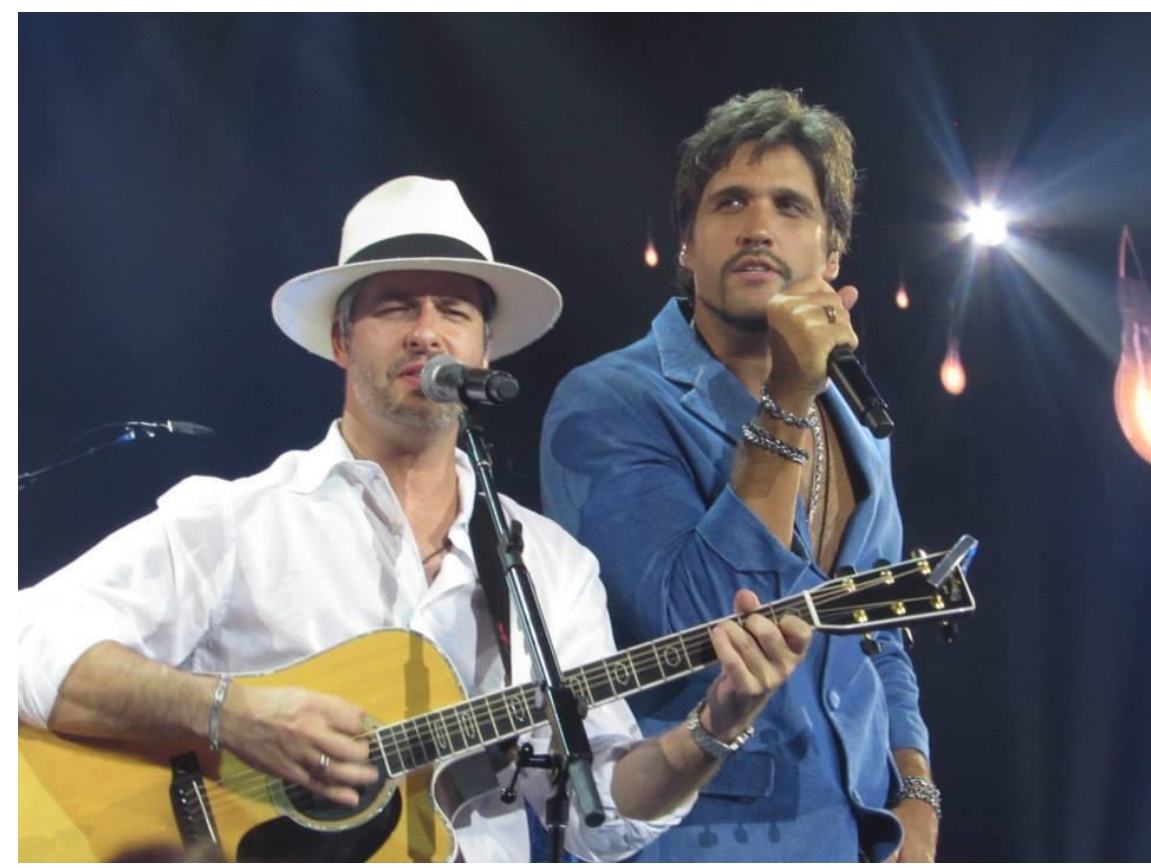

A personalidade introspectiva de um se integra à figura carismática do outro. No palco, cada um abraça seu papel: o "poeta" cândido de Victor e o cantor "virtuoso" viril e magnético de Leo. Enquanto um sempre aparece com os olhos semiabertos, o outro é provocativo e encara o público. Essas singularidades são traduzidas nas roupagens. O compositor (à esquerda) usa camisa social e chapéu panamá branco, enquanto Leo (à direita) investe em um traje mais despojado: um blazer azul com os botões abertos, exibindo o dorso e os acessórios. O selo Som Livre soube reelaborar a imagem comercial de Leonardo. Hoje, as estratégias de apelo corporal também fazem parte da encenação de Leo nos shows. Foto: Edy Betty.

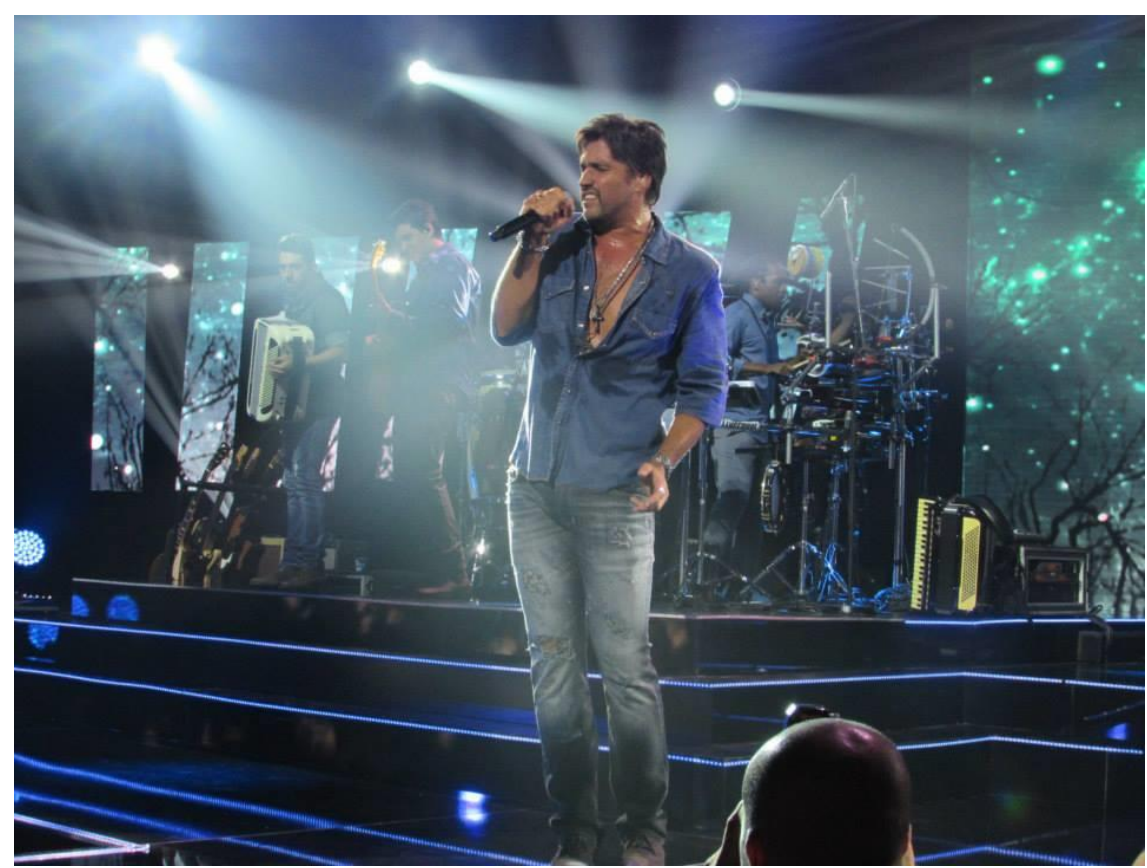

No palco, Leo se reinventa. De acordo com o enredo, o cantor assume uma personalidade específica. Em Primeiros Erros, os trejeitos do intérprete mudam: ele retorce o corpo, abusa do canto em falsete e faz cara e bocas para transmitir emoção à balada pop rock. A camisa social semiaberta deixa à vista o contorno do tórax e dos medalhões que o adorna. A transpiração faz com que as roupas justas e decotadas realcem o corpo atlético. Foto: Edy Betty. 

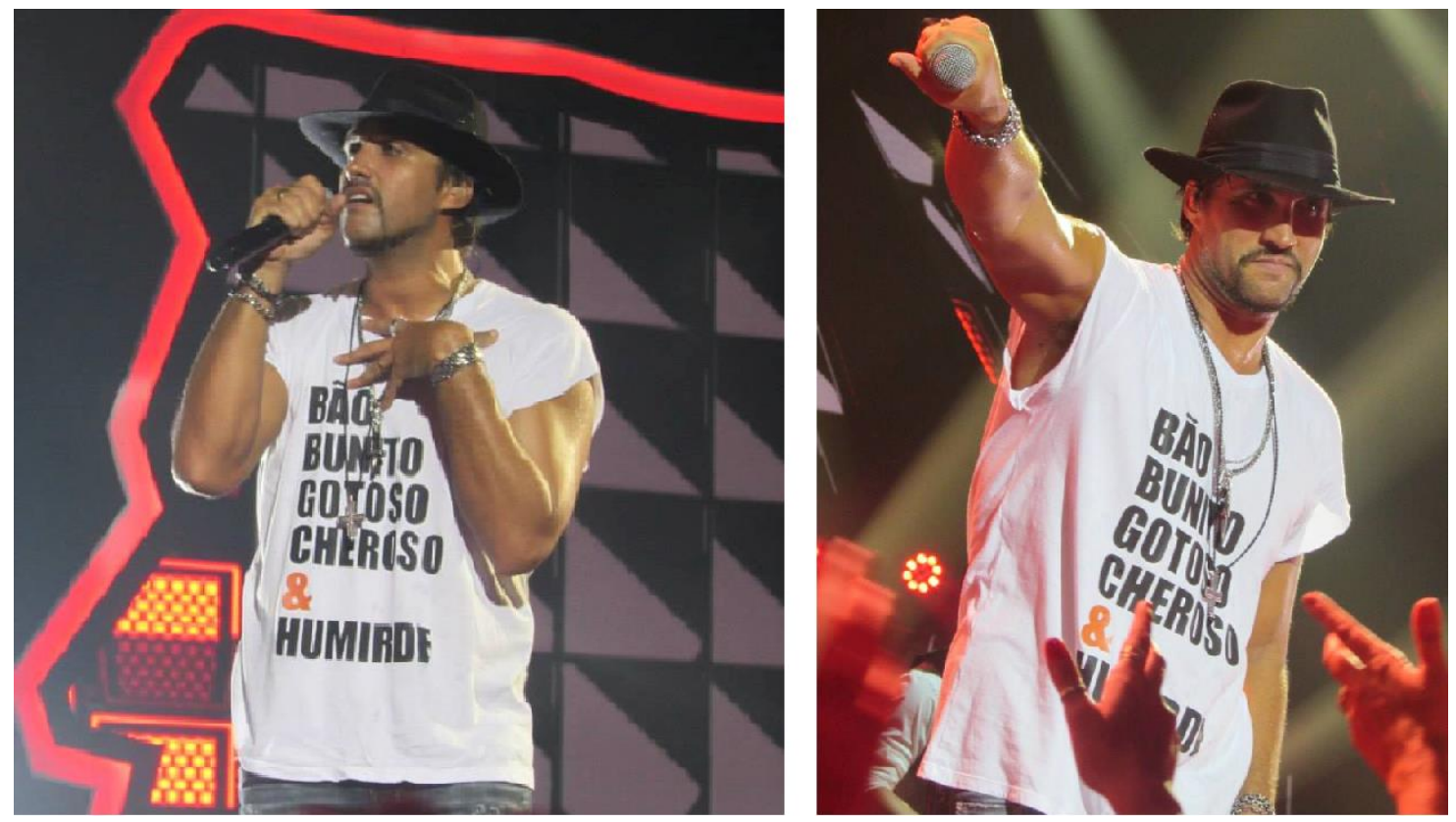

$\mathrm{O}$ artista não dispensa o uso de acessórios. O chapéu estilo mariachi sempre está presente em suas apresentações.

O figurino também é uma peça fundamental para o cantor. Na gravação do DVD, escolheu uma regata estampada: "Bão, Bunito, Gotoso, Cheroso e Humirde". A grafia propositalmente errada e a mensagem excêntrica fazem parte do seu personagem. Mas, Leo sabe dosar sua sensualidade. Se em uma cena, ele chega a desmunhecar, abrindo os pulsos e deixando as mãos soltas (à esquerda), em outra, ele firma os punhos, até ressaltar os músculos torneados do braço (à direita). A conciliação entre "afeminação" e "virilidade" é bem construída em sua imagem. Mas, não somente nela. Enquanto apresentava Conheço Pelo Cheiro (as duas fotos foram registradas na exibição dessa música) outra polaridade surge: "romantismo" e "sensualidade": "Então saímos pela rua/Naquela noite escura/O Cheiro dela tinha luz, encanto e ternura/ Como sabia que era eu?/Ela me perguntou/Eu disse: meu bem conheço pelo cheiro quem é o meu amor". Leo ajusta o tom sensual com o romântico em uma mesma interpretação. Foto: Edy Betty.
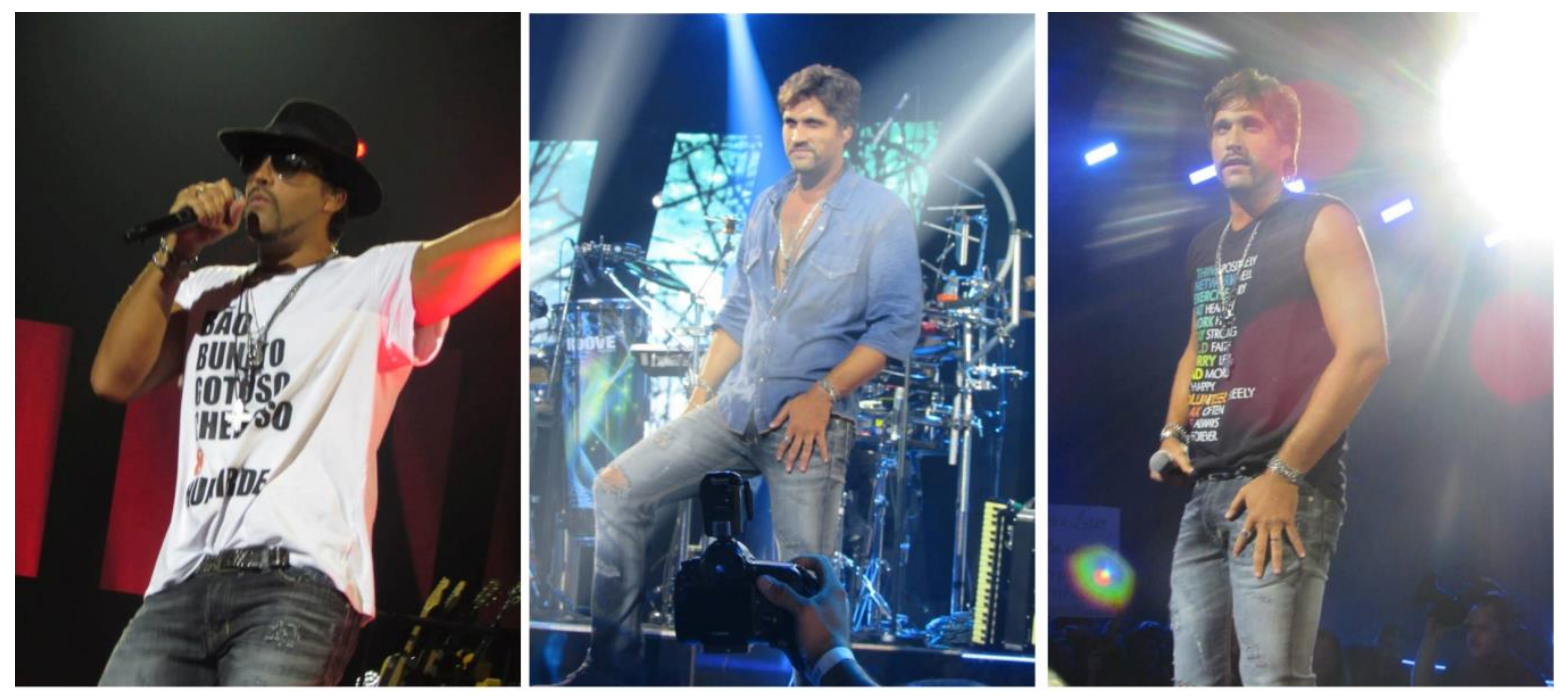

Na escolha do figurino, o cantor é democrático. Se o cenário ou a canção pede mais dramatização, ele usa acessórios exóticos e aposta no molejo dos quadris. Para o ritmo mais pop, arrisca um jeans desfiado com uma camisa social entreaberta e faz um meio sorriso. Agora se for rock, investe em uma regata estilizada e assume uma postura corporal ereta e uma expressão facial mais fechada. Porém, o contato visual com a plateia nunca cessa. Foto: Edy Betty. 


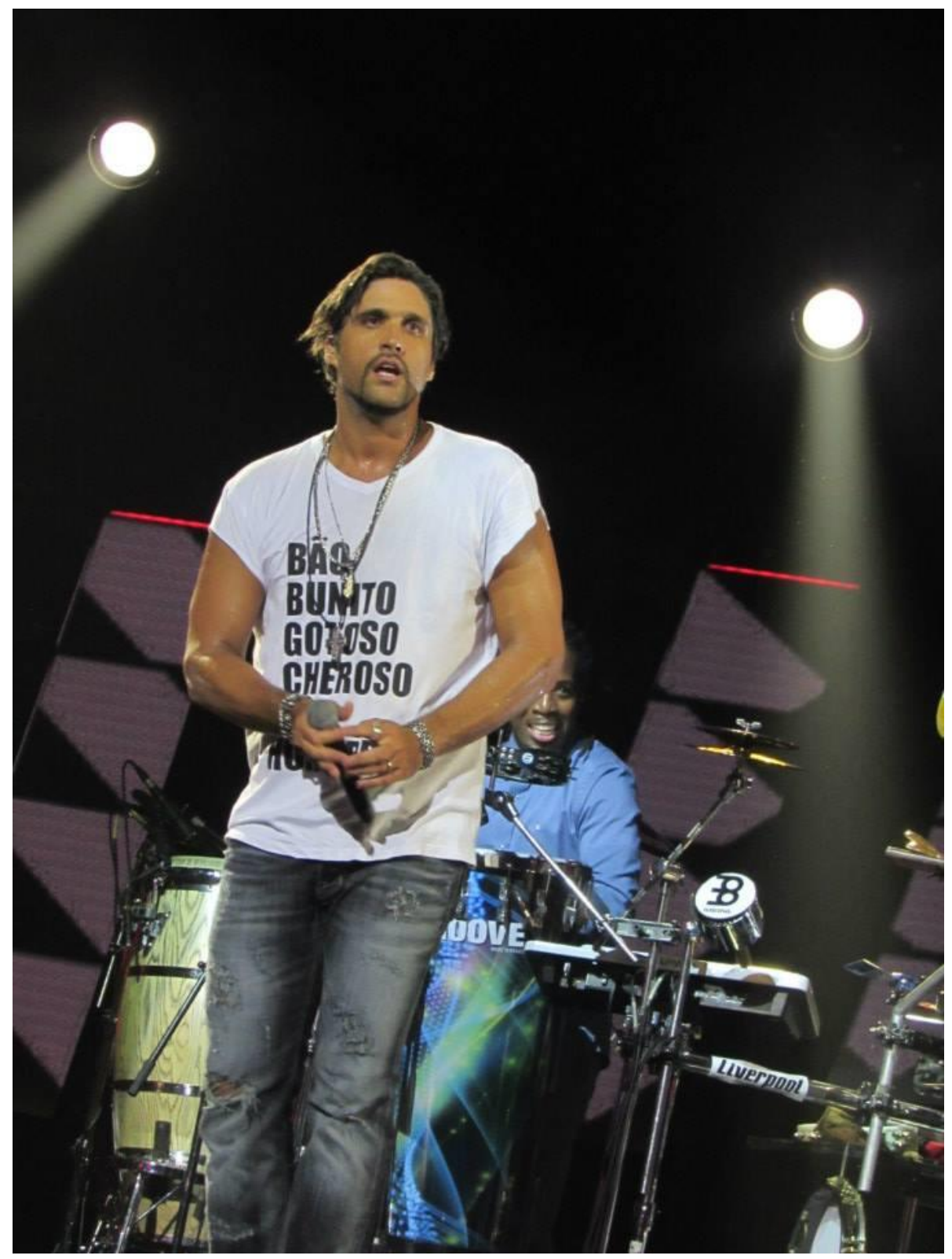

Leo é o protagonista da cena. $\mathrm{O}$ artista-atleta com agilidade e sagacidade para fazer o enredo do show se transformar em uma maratona. No final, a transpiração é inevitável. O suor que bagunça os cabelos traz à tona a robustez do seu porte físico. Os dizeres "bom, bonito, gostoso, cheiroso e humilde" não resiste a tanta movimentação. Mas até a naturalidade do cansaço lhe cai bem: mostra o vigor do atleta-artista. A personalidade perspicaz de Leonardo é assumida por todos os seus personagens. Ele sabe a hora de acelerar a apresentação, de dar bronca no irmão sem parecer grosseiro, de se irritar com o contratante no meio da exibição sem ofendê-lo diretamente, ou até mesmo de criticar o artista que lhe dá um cano no dia da gravação. "Humirde" é um adjetivo apropriado para designá-lo. Não que ele seja propriamente humilde, mas sabe conciliar carisma e excentricidade em uma mesma figura cênica. Ser popular sem se fazer comum. O cantor que chama o público para vê-lo brilhar no palco. Que nota a dispersão da plateia e de prontidão dispensa os minutos de descanso para trazê-la de volta ao auditório - à capela e sozinho. O atleta-artista que "convida" as fãs para aguardarem longas horas por ele do lado de fora, em um ambiente inóspito, apenas para abraçá-lo e receberem de volta um sorriso de agradecimento. Leo não apenas "pede" que participem do espetáculo, mas também que façam parte da sua maratona. Foto: Edy Betty. 


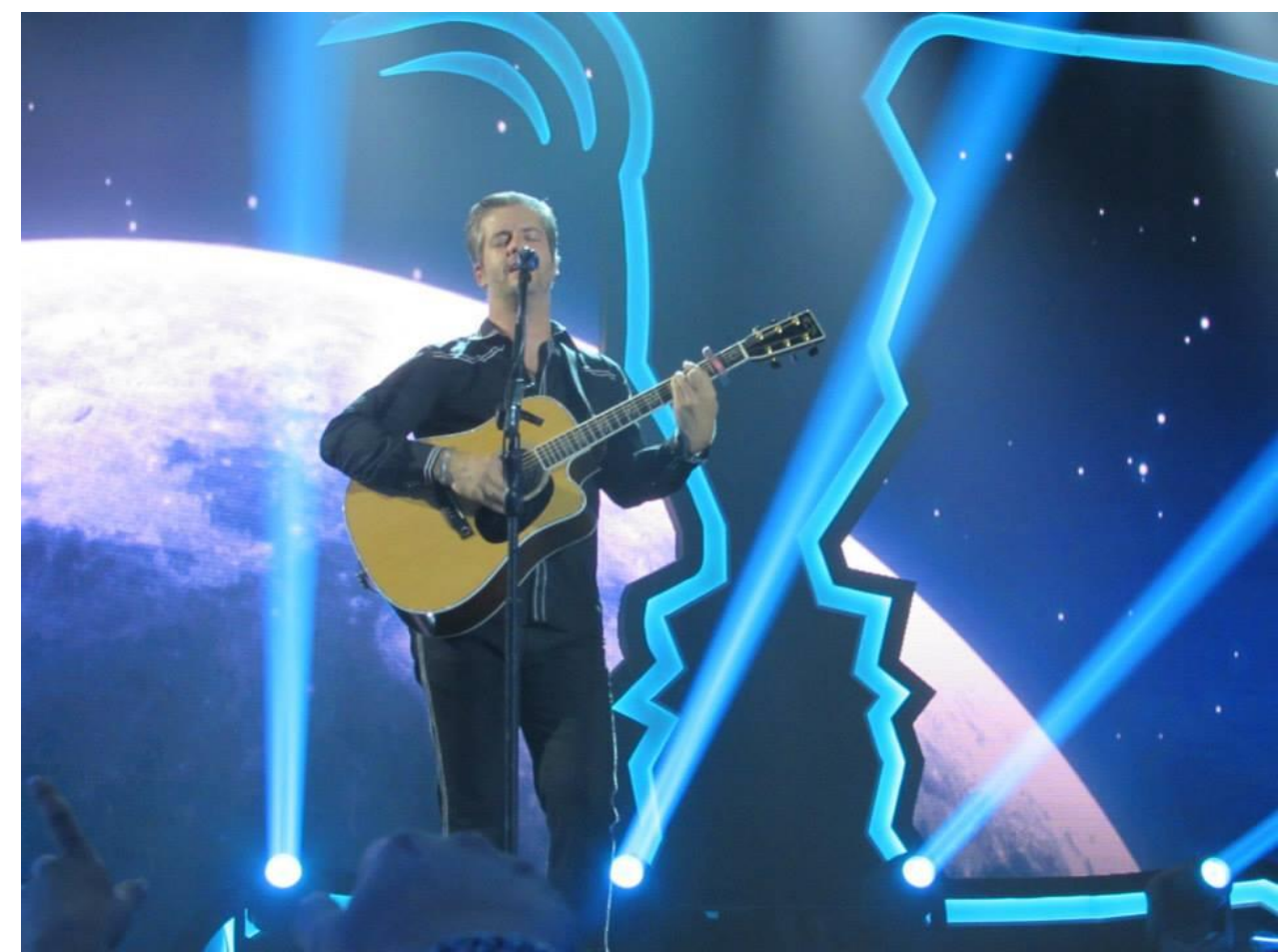

As cores das lâmpadas e as projeções do cenário enriqueciam a apresentação. Elas marcavam o ritmo e a personalidade de um e de outro. O compositor é conduzido por luzes azuis e pela imagem da lua. Dessa vez, ele assume centralização no palco. Enquanto mantém os olhos fechados, as mãos manejam o violão com leveza e naturalidade. Seja como músico ou como intérprete, o tom de modéstia e despretensão o acompanha sempre. Toda essa áurea do artista romântico faz parte do seu personagem principal - o poeta. Uma figura cênica que toca e canta para si mesmo, desejando apenas fruir a sua própria arte e sem despontar interesse em cativar o público-consumidor. A ideologia carismática do "dom" é incorporada tanto no seu discurso quanto na sua héxis corporal. A simplicidade e a sutileza dos movimentos dão gracejo e singeleza à interpretação da trama. Foto: Edy Betty.

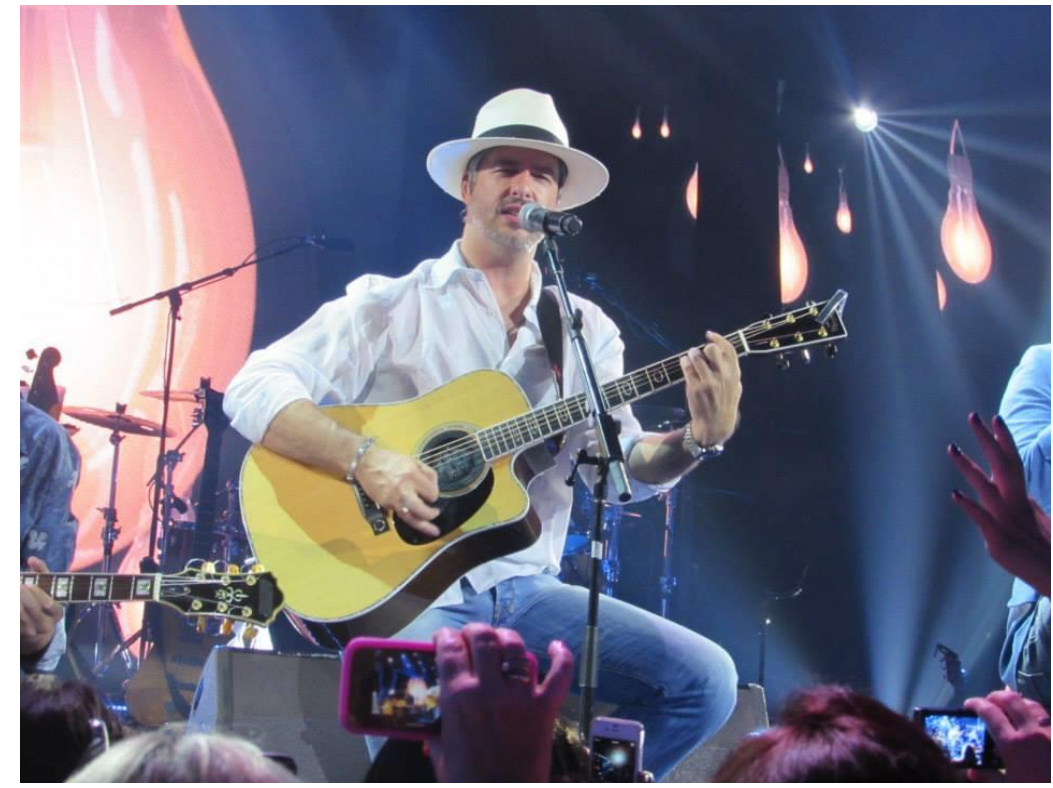

Com olhar cândido, Victor senta-se à beira do palco, vestindo chapéu e camisa branca. Cuidadosamente, dedilha o violão e solicita o "sertão místico" que compõe seu personagem. Mas, Victor sabe a hora de encarar a plateia e fazer poses para as fotos, ainda que os olhos fiquem apenas semiabertos. Foto: Edy Betty. 


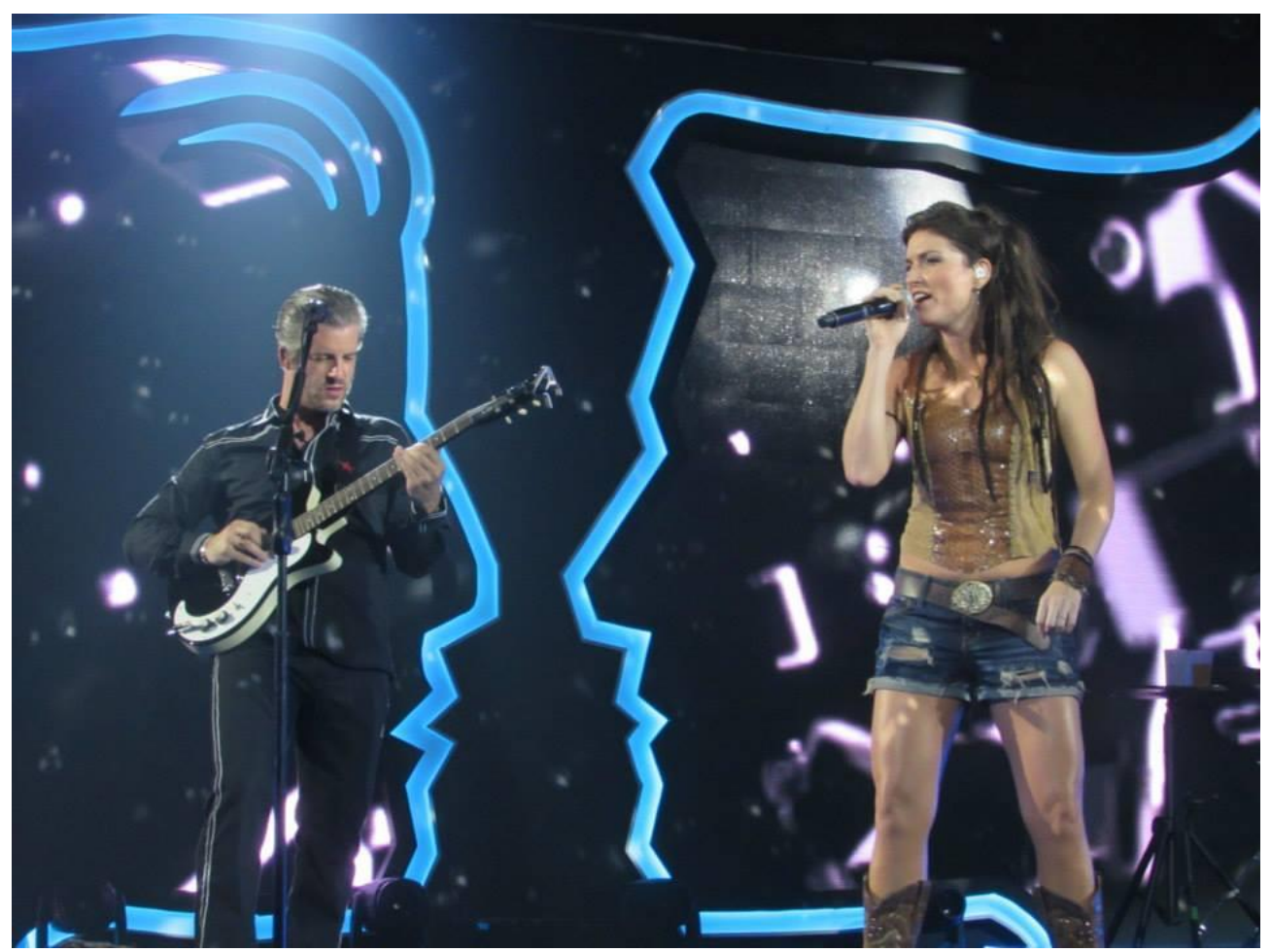

Uma prática muito comum nos shows sertanejos é a divulgação dos "apadrinhados". Há todo um ritual feito pelo padrinho para apresentar a "nova promessa da música sertaneja", inclusive ofertando espaço para que eles possam se popularizar. Esse sistema de parceria é tradicional no gênero. O terceiro artista tem a função de complementar o show ou de poupar o vocalista por alguns minutos. A encenação musical também se torna mais polissêmica e ágil. Nas apresentações de Victor e Leo, em São Paulo, Lucyana Villar (à direita) está sempre presente. A cantora faz parte do elenco da casa noturna sertaneja Brooks (no bairro de Santo Amaro) e é bem conhecida pelo público paulistano. Com o seu bordão: "A energia daqui é incrível e diferenciada", a carismática cantora entra no palco. Os atributos físicos também são um "diferencial". A beleza da moça não passa batida. Algumas fãs ciumentas chegam a rejeitá-la por ser bonita e sensual. A propósito, a exaltação da simetria feminina é uma lei da música sertaneja. Está presente nos bastidores, no auditório e claro no palco. Lucyana Villar personifica a regra desse jogo. Foto: Edy Betty.

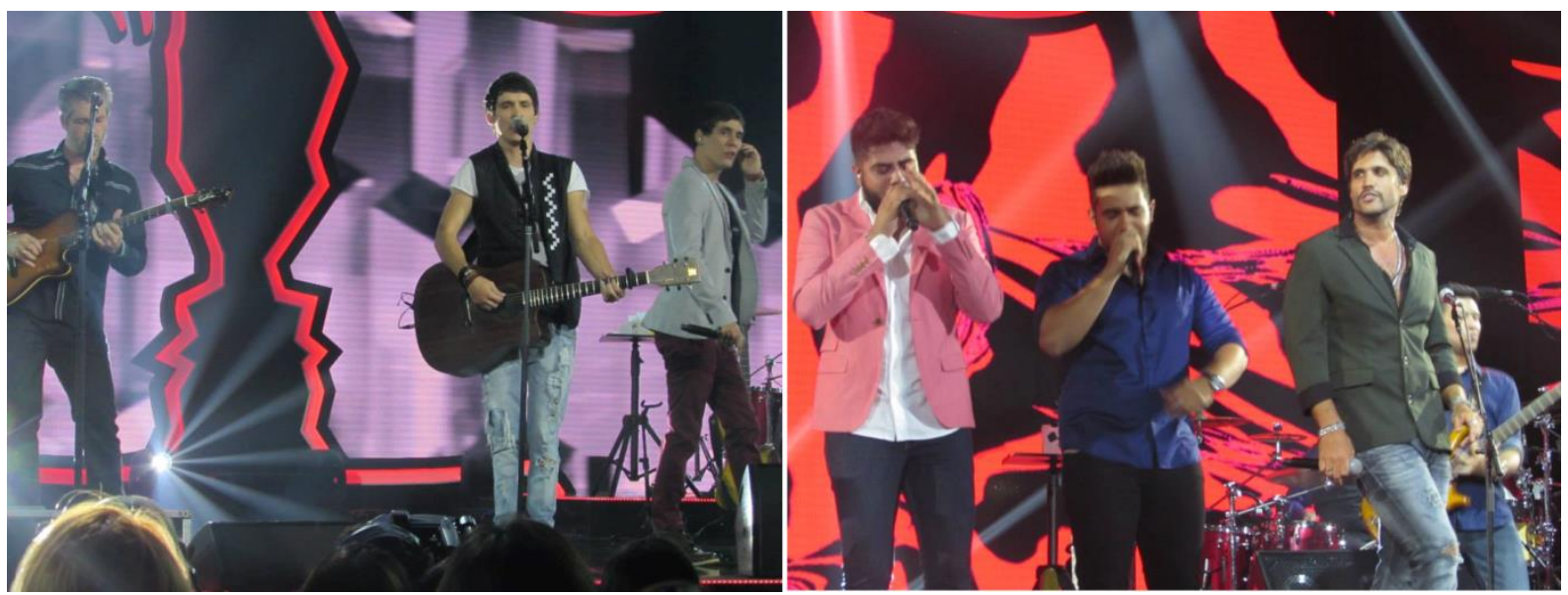

À esquerda, os novatos Victor Freitas e Felipe. Os gêmeos mineiros não conseguiram conter o nervosismo e ficaram introspectivos no palco. À direita, Henrique e Juliano. Os músicos universitários souberam embalar o show. Foto: Edy Betty. 


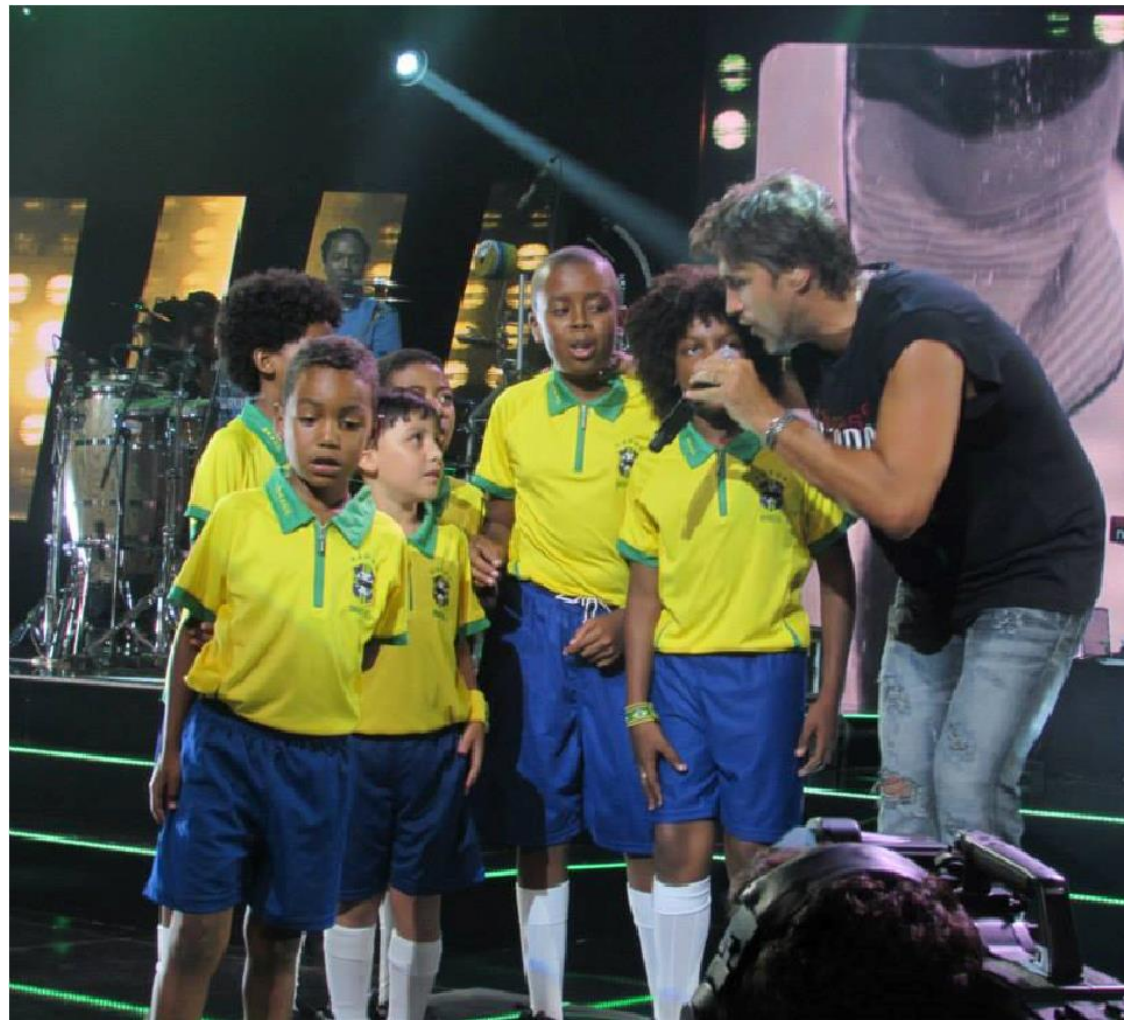

"Tio Leo" e seu time de atores mirins, vestidos como jogadores da seleção brasileira de futebol. Tiveram que chutar as bolas para a plateia e ficaram ansiosos com a regravação da música Guerreiro. À esquerda, o pequeno ator não esconde sua preocupação com a pelota, enquanto o resto do time ouve atentamente os "treinamentos" do técnico. Foto: Edy Betty.

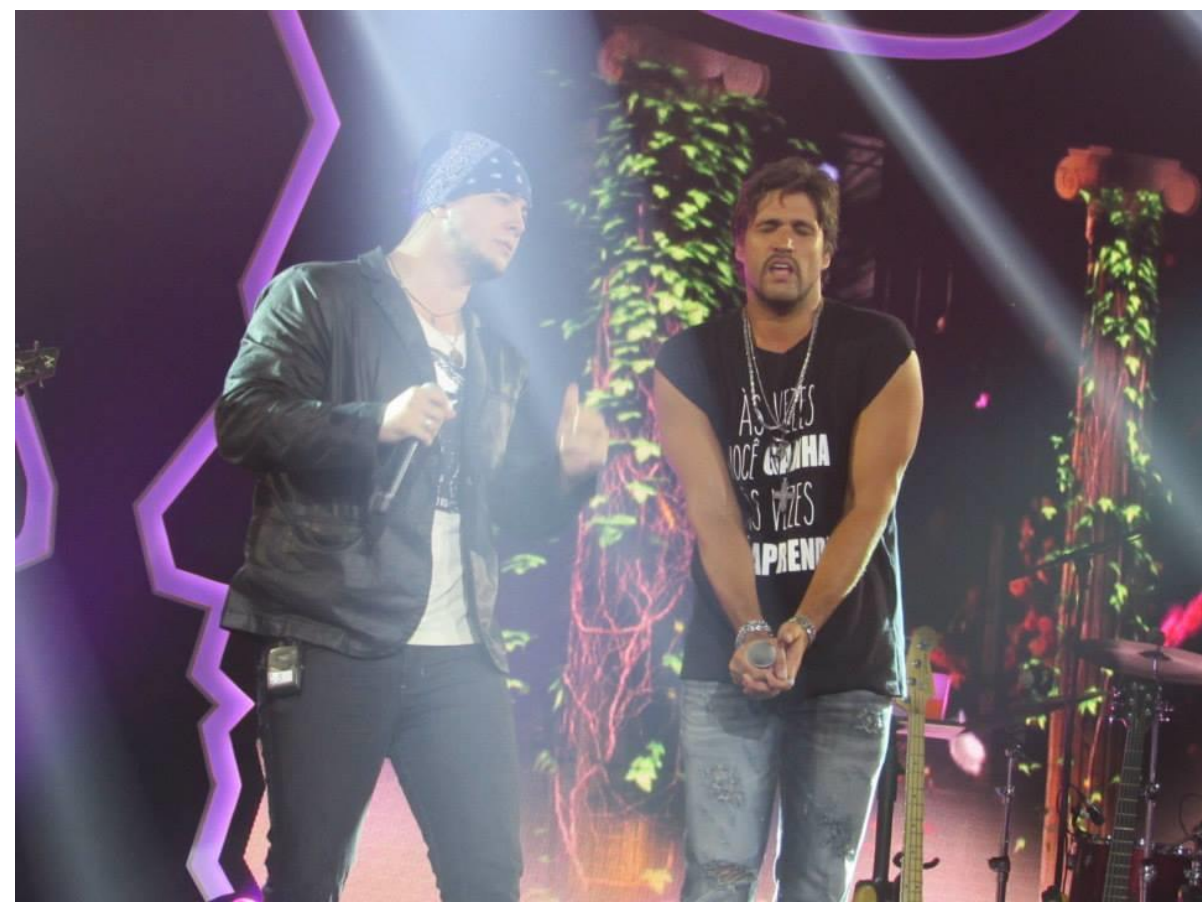

A banda Malta foi a última convidada do primeiro dia de gravação. À esquerda, o vocalista da banda, Bruno, e à direita, Leo Chaves. O cantor apareceu com uma regata estampada: "Às vezes você ganha. Às vezes você aprende". Realmente, o cantor aprendeu a receita de sucesso para um show. Os trejeitos corporais contorcidos são iguais aos de Mick Jagger e de outros artistas roqueiros do cenário internacional. Foto: Edy Betty. 


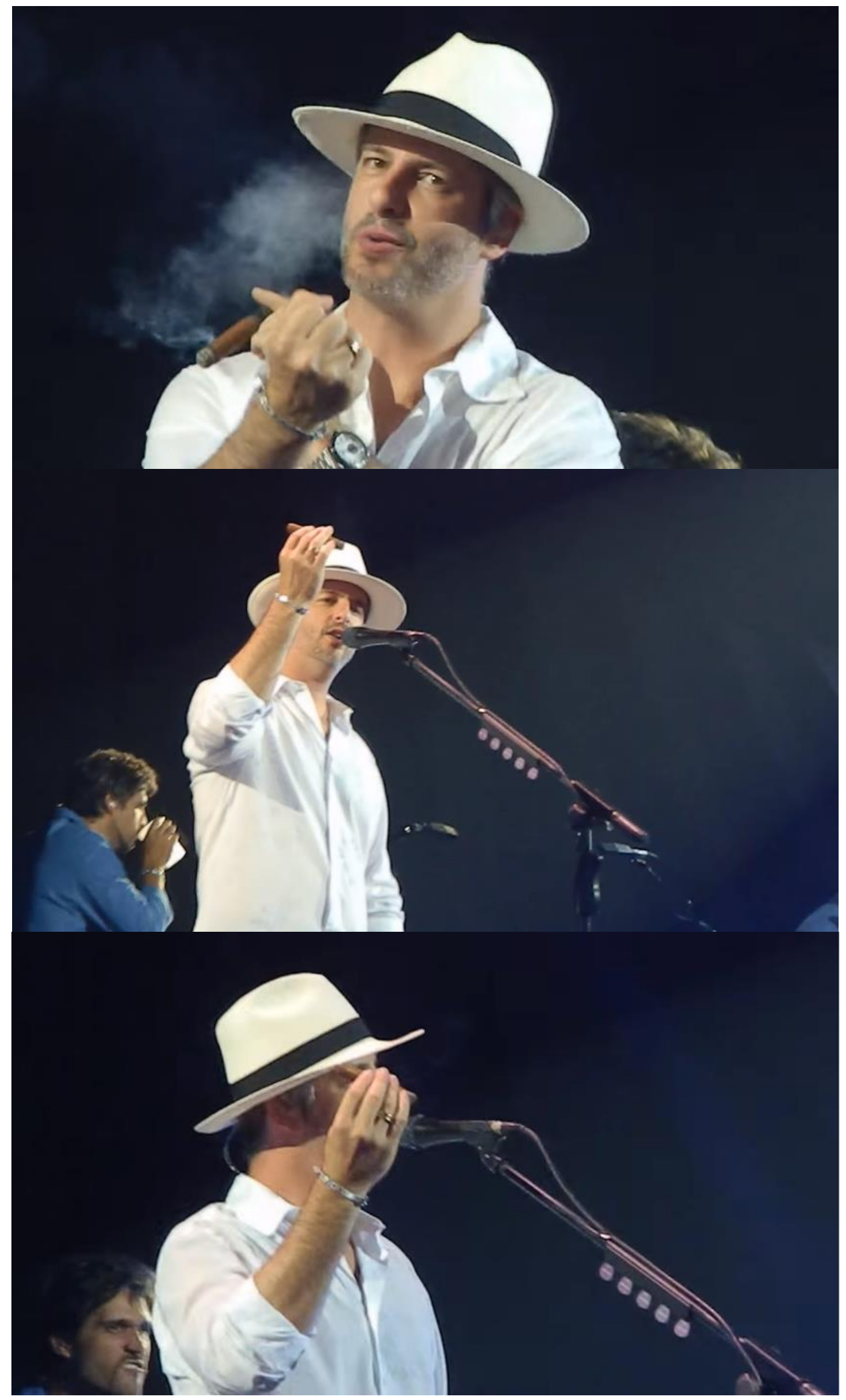

Gravação do DVD ao vivo em São Paulo: Irmãos (28 de janeiro de 2015) no Estúdio Quanta. No meio da apresentação, o compositor Victor Chaves volta aos palcos baforando um charuto "suspeito". Transbordando sarcasmo no olhar, o "poeta" caipira contorce os punhos em um sinal "de tô nem aí" às câmeras. Nesse episódio, as fãs foram respeitosas com a dupla: abaixaram os aparelhos fotográficos para que nenhuma imagem fosse compartilhada nas redes sociais. Quem não gostou da encenação do irmão foi Leonardo Chaves. No canto inferior esquerdo, a expressão de ódio na cara do cantor é incontestável. Foto: do autor. 
Aos desafetos, com afeto (Victor Chaves) Carinhosamente, o charuto me faz tão bem quanto pouca gente me fez e bem menos mal que meus piores defeitos, os quais poderão me matar bem antes dele. Ademais, não conhecem charuto, aqueles que o comparam a coisas detestáveis, assim como nós sobre o amor, que sempre o confundimos com nossos egoísmos, opiniões antecipadas, condições e outros de seus antônimos. Embora 0 charuto seja algo muito diferente do cigarro( e não estou defendendo nenhuma causa ) é bom lembrar que é muito fácil julgar quem fuma e/ou bebe porque são atos visiveis. Exponha seus defeitos ocultos. Aqueles, como ciúmes invejosos, mágoas antigas, indiferença social, felicidade de fachada, maldizeres pelas costas, desperdicio de tempo em vida com notícias inúteis, auto-insatisfação, mentiras diárias, e comparemos a um bom charuto, um bom vinho, uma cerva gelada ou o que the agrade, depois de um dia de trabalho, de preferência em boa companhia.

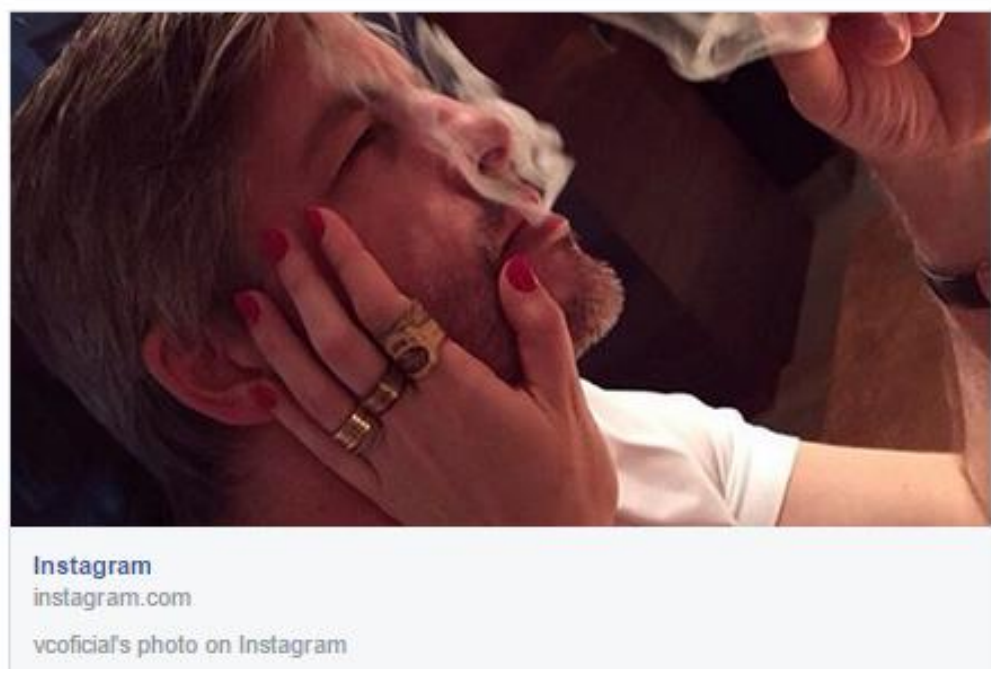

A polêmica do charuto "suspeito" foi iniciada no dia 06 de novembro de 2014. Victor Chaves usou sua conta oficial no Instagram para publicar uma foto tragando o tabaco. A imagem foi acompanhada por um bate-boca na rede social entre os seus seguidores. A dupla sertaneja tem um grande público infanto-juvenil e Victor foi acusado de não preservá-los do seu vício. Nos comentários, as fãs veteranas se disseram profundamente abaladas com a postura do músico e com suas réplicas (referindo-se a elas como desafetos). Na fotografia, o compositor está “em boa companhia" de uma mão feminina que o acaricia. Com os olhos semifechados, a fumaça é lentamente desfrutada em uma expressão de gozo facial. No entanto, o teor da legenda, escrita pelo sertanejo, não é tão prazeroso assim. Victor transmite no texto um sentimento de contragosto ou inadaptação do ambiente artístico e das pessoas que estão a sua volta. No decurso dos anos, a postura humilde, acanhada e introspectiva do músico foi sendo substituída por um tipo de comportamento comum aos artistas vanguardistas: o culto romântico à personalidade excêntrica. Mas, no mercado fonográfico sertanejo, essa postura não é vista com bons olhos. Leonardo Chaves sabe disso como ninguém e, embora seja discreto publicamente, o cantor fica nitidamente transtornado com as atitudes passionais do irmão. Por outro lado, a presença do compositor é fundamental para o sucesso do dueto. Victor é aquela figura cênica platônica que mexe com o imaginário afetivo do público feminino da música sertaneja. O protótipo do macho-alfa é destinado a Leonardo. E esse equilíbrio de tensões sexuais entre os dois é o que lhes dá acesso à audiência nacional. Foto: Instagram de Victor Chaves. 


\section{A balada pop sertaneja de Fernando e Sorocaba}

O nosso grande diferencial é a inovação. Levamos boa música aliada à diversão e entretenimento. Primeiro, trouxemos a grua que elevava eu e o Fernando a uma altura de até 20 metros por cima do público. Atualmente, um dos momentos mais esperados é a bolha, onde eu entro em uma enorme bola de plástico e vou por cima da galera até o palco. Também tem o disco voador, que vou voando por cima do público. Os fãs querem ver isso no show, e eles merecem. Já virou uma marca registrada da dupla ${ }^{361}$.

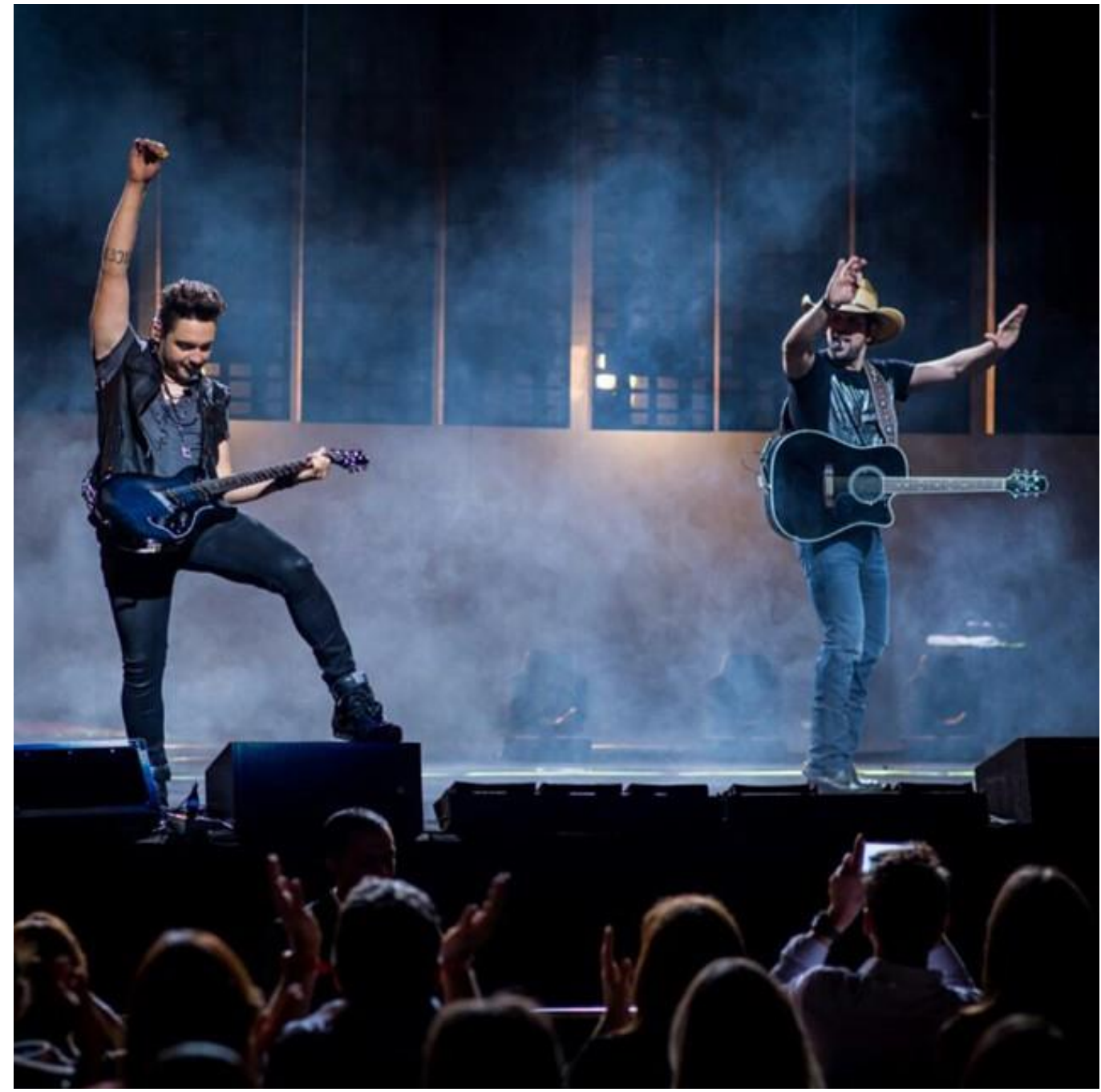

Fernando Zorzanello (à esquerda) e Sorocaba (à direita) embalam o público do Citibank Hall - 27 de setembro de 2014. Foto: divulgação. Sorocaba não dispensa o investimento tecnológico nas apresentações. O espetáculo é transformado em uma imensa balada eletrônica e a plateia é convidada a participar da festa.

${ }^{361}$ Entrevista de Fernando Fakri de Assis “Sorocaba” ao autor, 08 de abril de 2015. 
A proposta deste capítulo é trazer o registro das apresentações de Fernando e Sorocaba. Do mesmo modo que lidei com a outra dupla estudada, examinarei o componente cênico do show dos músicos sertanejos. Em São Paulo, os acompanhei em dois espaços:

(A) Citibank Hall, Santo Amaro (27 de setembro de 2014): ocupação total para sete mil pessoas. O ingresso saiu por $\mathrm{R} \$ 250$. Foi cobrado cerca de $\mathrm{R} \$ 20$ a mais do que no show de Victor e Leo.

(B) Terra Country Interlagos (10 de outubro de 2014): lotação máxima para mil espectadores. Aqui, o preço do ingresso foi menor, custando entre $\mathrm{R} \$ 50$ a $\mathrm{R} \$ 100$. Para constituição do trabalho, não tratarei deste show no texto.

Ter uma apresentação sediada no Citibank Hall (antigo Credicard Hall) de São Paulo não é para qualquer artista do gênero. Nos anos 1990, Chitãozinho e Xororó foram os primeiros músicos sertanejos a serem recebidos ali. A capital paulistana foi conquistada com muito suor por seus pioneiros. O público paulistano se mostrava indisposto a aceitar o novo ritmo e, muito menos, a apreciá-lo. Porém, o cenário econômico foi mudando e a plateia também. Pouco a pouco, foi surgindo uma nova classe-média urbana que passou a consumir esse tipo de música. Todavia, os estratos sociais com maior poder aquisitivo ou status cultural foram os públicos mais resistentes ao sertanejo romântico ${ }^{362}$. Até hoje, a crítica musical “especializada" também ${ }^{363}$. Na atualidade, o movimento universitário foi o responsável por ocupar essa fatia de mercado. Sobretudo, a clientela das casas noturnas de São Paulo. Os bairros nobres e centrais da capital, como, por exemplo, Vila Olímpia, Moema, Itaim-Bibi e Vila Madalena, antes redutos do rock, música eletrônica, MPB ou do samba, hoje, acolhem

362 Em O charme In (discreto) do gosto burguês paulista, Carolina Martins Pulici esboça algumas particularidades do público cultural paulistano: "Os gostos musicais também são atravessados pela estrutura das relações de classe quando o que se tem em vista é a MPB propriamente dita, corroborando a opinião de Carlinhos Lyra, que a associa a classes sociais e, não, a gerações. Se 36,5\% das classes A/B elegem-na como gênero predileto, apenas $18,8 \%$ da classe $\mathrm{C}$ e $12,1 \%$ das classes $\mathrm{D} / \mathrm{E}$ afirmam o mesmo. E o peso do capital escolar também é aqui fundamental: 47,2\% dos paulistanos de alto nível de escolaridade, 25,8\% dos de média e $11,6 \%$ dos de baixa escolaridade afirmam ser a Música Popular Brasileira seu gênero musical favorito. Inversamente - e levando em conta todo o território nacional -, o 'tecnobrega' dos paraenses da banda Calypso e o 'sertanejo romântico' da dupla goiana Zezé Di Camargo e Luciano são, de acordo com uma pesquisa do Datafolha, mais ouvidos entre os de menor nível de escolaridade, evidenciando como as preferências culturais seguem de perto as hierarquias sociais" (2010, p.86).

${ }^{363} \mathrm{Na}$ pesquisa documental, coletei dezenas de textos que apontam essa indisposição intelectual. Na realidade, todos esses autores reproduzem mais um conhecimento dóxico do que uma crítica musical formal. Sugiro que essa lacuna possa ser retomada por outros acadêmicos. 
com bom grado o gênero - seja em bares ou nas baladas. Fernando e Sorocaba estão presentes em todos esses espaços.

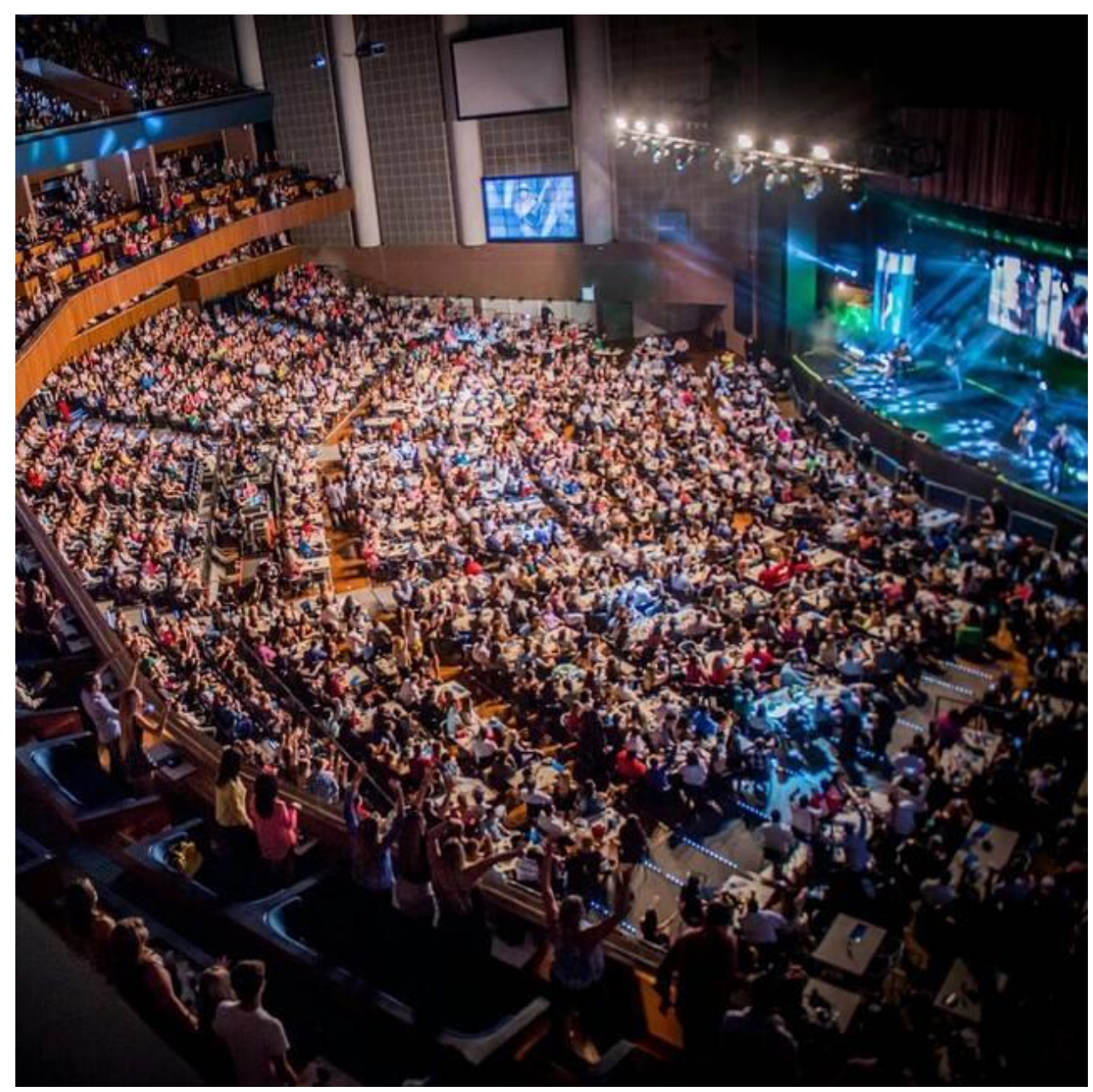

No segundo dia de apresentações, Fernando e Sorocaba trouxeram sete mil espectadores ao Citibank Hall. O espaço ficou até pequeno perto do imenso público. Foto: divulgação.

Entre os dias 26 e 27 de setembro, a dupla sertaneja voltou aos palcos do Citibank Hall. Tanto na sexta-feira quanto no sábado, todos os 3.820 assentos do auditório estavam ocupados. Os funcionários distribuíram o público pelos confortáveis setores da casa de espetáculos. O espaço comporta três camarotes superiores com vista panorâmica e, no piso inferior, há dezenas de mesas ou poltronas para o auditório ${ }^{364}$. Por volta das $20 \mathrm{~h}$, o trânsito na Avenida Nações Unidas já ultrapassava $5 \mathrm{~km}$. Bete Ferreira, a assessora de imprensa de Fernando e Sorocaba, concedeu-me uma pulseira da produção, o que deu acesso sem restrições a todos os ambientes da casa, inclusive ao camarim e ao palco. Uma hora antes do

\footnotetext{
${ }^{364}$ Citibank Hall conta com um sem-número de seguranças privados, posto de atendimento médico, brigada de incêndio, bombeiros e recepcionistas.
} 
show, sentei em uma cadeira improvisada ao lado do palco. $\mathrm{O}$ show previsto para começar às 22h foi adiado em uma hora - atraso curto se comparado às quatro horas habituais de Victor e Leo. No total, foram duas horas de balada sertaneja e eficiência tecnológica. O écran digital ocupava quase que a totalidade do próprio palco. $\mathrm{Na}$ lateral, dois monitores LED de alta resolução 3D arremessavam os efeitos pirotécnicos e ilusionistas no auditório. A qualidade digital tomava conta do ambiente. O público era convocado a mergulhar na imensidão de imagens que compunham o espetáculo. A inovação prometida por Sorocaba é sempre cumprida.

Cinco minutos antes de entrarem em cena, a tecnologia tomou conta do palco. Nos painéis rotacionais, as figuras ganhavam vida, tamanha qualidade física e sensorial. No centro, o monitor principal começou a rodar uma espécie de filme. Na interpretação, Fernando apareceu pescando, enquanto Sorocaba fingia estar na lida com o gado. Eis que o músico recebeu uma mensagem no celular, alertando sobre o "atraso" para o show em São Paulo. Imediatamente, Fernando liga para o companheiro:

- Oi, Sorocaba, pode falar!

- Oi Fernando. Onde você está?

- Estou num barco, estou pescando!

- Cara, nós estamos atrasados demais bicho. Hoje tem show!

- Show? Show onde?

- Em São Paulo, no Citibank Hall.

- Fernando, corre, corre que eu estou indo para o aeroporto!

- O loco rapaz! Estou indo, estou indo!

A película introdutória prosseguia com a dupla correndo às pressas para o aeroporto. Finalmente, o avião "aterrissou" sob o palco e o som das turbinas e das hélices foram reproduzidos com exatidão. A cortina subiu e o espetáculo começou. A abertura quase cinematográfica é outra engenhoca maquinada por Sorocaba. Dessa vez, não estacionaram um caminhão, mas um avião no palco. Para Marília Neves, jornalista do portal IG Sertanejo, isso não é novidade, pois quem assistiu aos shows dos sertanejos em espaços maiores, já viu os dois descendo de um caminhão, que estacionava no palco. Tudo, claro, graças às telas de LED que se movimentam em efeito 3D, dando uma ilusão real. Hoje, esse desembarque acontece em um avião, após alguns minutos de encenação da dupla: "Sorocaba trocou o disco voador 
que passa por cima do público pelas próprias pernas para aparecer ao fundo da casa e fazer seu trecho solo. Já Fernando aguardou a volta do parceiro cantando modões sertanejos, mas sem poupar os fortes acordes de sua guitarra" ${ }^{\text {} 365}$.

A narrativa fílmica era acompanhada por dois ambientes opostos: o universo rural interpretado por Fernando Zorzanello, em um barco à pesca, e Sorocaba, na lida do gado - e o espaço urbano - representado pelo aeroporto, a cidade de São Paulo e pelo show. O aparelho celular era o mediador: cessava a rotina tranquila do espaço rural e trazia a mensagem de cobrança da experiência moderna. Quando o avião pousou no palco, essa agitação se dissipou e tudo foi transformado em uma grande festa musical - não as mesmas festas dos bairros tradicionais caipiras, que indicavam o fim da missa (rito sagrado) e o início dos encontros musicais (rito profano), conduzidos ao som da viola de arame. Essa aqui é outra festa. Em balada pop sertaneja, nada de violinha improvisada com arame farpado. O violão - e em cordas de aço - concorre com dezenas de instrumentos eletrificados de alta qualidade sonora. Fernando e Sorocaba embalam o público com música sertaneja e inovação tecnológica. A tradicional moda de viola ou os modões sertanejos cantados por Fernando são complementados pelos fortes acordes de sua guitarra elétrica. Sorocaba aparece tanto em um caminhão quanto em um avião ou em um disco voador. No palco, tradição e modernidade são conciliadas em entretenimento.

No show para o Citibank Hall, Sorocaba não dispensou o clássico chapéu de caubói. Trajava camisa social lilás, fivela de cinto dourada, calça jeans justa e bota - não qualquer uma, mas em couro de cobra. Além da indumentária extravagante, o excesso de maquiagem chamava a atenção. Se Victor e Leo apostam no quesito naturalidade para realçarem a beleza física, Sorocaba adere a uma imagem visual mais sintética e caracterizada. Fernando é mais discreto: usa calça e colete de couro, camiseta preta bem ajustada ao corpo e botinas no estilo rock and roll. O músico tem algumas tatuagens e gosta de exibi-las. Sorocaba foi o único a trocar de roupa na apresentação (camiseta preta estampada, fivela mais discreta, calça jeans e tênis). No palco, eles investem em calças justas que destacam os quadris. Entretanto, sabem dosar e revezar o apelo erótico. Sorocaba minimiza a sensualidade no caminhar desajeitado, na postura levemente curva, no forte sotaque interiorano e no tom de voz quase ingênuo. Já Fernando se entretém com os instrumentos e não arrisca movimentos acrobáticos fora do palco, como faz o parceiro.

\footnotetext{
${ }^{365} I G$ Sertanejo: Fernando e Sorocaba trocam caminhão por avião em nova turnê, 28/09/2014.
} 
Fernando e Sorocaba estavam em fase de divulgação do novo álbum Mármore. O público, porém, esperava ouvir as músicas famosas, popularizadas pela dupla sertaneja. No show, eles trouxeram 32 canções, tanto as inéditas quanto as já consagradas. Em duas horas, exibiram hits do rock como Pais e Filhos (Legião Urbana) e Sweet Child O'mine (Guns N'roses). Só que o coral do Citibank Hall veio mesmo com Domingo de Manhã (Marcos e Belutti) - a música mais tocada nas rádios, em 2014. Inclusive, Fernando é o produtor musical da nova dupla sertaneja. Já Sorocaba é o empresário deles. Os modões de viola ficaram por conta das músicas consagradas do gênero sertanejo, como Pensa em Mim (Leandro e Leonardo), Boate Azul (Milionário e Zé Rico) e O coração está em pedaços (Zezé Di Camargo e Luciano). Evidências e Fio de Cabelo de Chitãozinho e Xororó foram recebidas com clamor pelo público. Aliás, Fernando é o atual responsável pela produção e direção dos álbuns de Chitãozinho e Xororó ${ }^{366}$.

A figura artística de Fernando Zorzanello é uma incógnita. Em 2005, Fernando Fakri de Assis "Sorocaba" patenteou a sigla "Fernando e Sorocaba". Entre 2005 e 2007, o primeiro "Fernando" da dupla sertaneja foi o músico Humberto Santiago. Durante a entrevista, Sorocaba disse que não poderia comentar a polêmica por ordem dos advogados; preferiu tecer elogios ao novo companheiro ${ }^{367}$. Ele também não divide os lucros dos shows com o parceiro. Zorzanello recebe um salário/cachê (não se sabe o valor) e não tem o protagonismo do dueto. É como se fosse um músico/cantor qualquer contratado pelo escritório. A rotina artística de Fernando é frenética. Ele concilia duas funções: presta serviço como produtor e diretor musical de três artistas sertanejos (Chitãozinho e Xororó, Rio Negro e Solimões e Marcos e Belutti) e faz dueto com Sorocaba.

O relacionamento estritamente comercial entre os músicos chama a atenção. Victor e Leo são exemplos opostos, gostam de valorizar os laços familiares e a parceria musical. Não

\footnotetext{
366 “O novo DVD da dupla, "Do tamanho do nosso amor", traz Chitãozinho \& Xororó numa roupagem atualíssima, com arranjos contemporâneos aplicados a músicas consagradas da carreira e a algumas inéditas de compositores com grande importância atualmente dentro do segmento sertanejo. O mérito, em primeiro lugar, é do Fernando Zorzanello, do dueto Fernando \& Sorocaba, que produziu este disco e rejuvenesceu, mais uma vez, a dupla Chitãozinho e Xororó". Fonte: Blognejo: Chitãozinho e Xororó - Do tamanho do nosso amor, 25/12/2013.

${ }^{367}$ Em uma entrevista cedida ao portal Universo Sertanejo (13/05/2013), o jornalista André Piunti questionou Sorocaba sobre o pouco destaque artístico oferecido a Zorzanello: "Não é bem assim. Ele ganhou o espaço dele, foi muito natural. Ele é um cara diferente. Desde o primeiro show que eu fiz com ele, praticamente seis anos atrás, eu sabia que precisaríamos explorá-lo muito no futuro. Sabia que ele era ótimo no piano e na guitarra, mas no começo não havia espaço para isso no show. O tempo foi mostrando quem ele era, e hoje ele tem no currículo a produção dos últimos CD's do Luan Santana e do Chitãozinho e Xororó. Eu defendo tanto que a gente precisa de artistas diferentes, e ele é justamente um deles. Ele agrega muito, não é apenas mais um. Ele tem suas cartas nas mangas, vai surpreender muita gente ainda".
} 
saberia dizer se existiram outros "Fernandos" além desse e de Humberto Santiago. O professor Ivan Vilela diz que sim: "Este Sorocaba é o dono da banda e um grande empresário. Ele já arrumou vários Fernandos"368. No decorrer da pesquisa, não encontrei outros "Fernandos", sequer reuni informações mínimas para reconstruir a trajetória social do atual. Portanto, tratei de personificar "Fernando e Sorocaba" em apenas um personagem. Sorocaba é o homem do show business da música sertaneja brasileira. Atua como artista e empresário do gênero. Em 2014, não renovou o contrato com o selo Som Livre. Desde então, administra a própria carreira e de mais três duplas sertanejas no seu escritório FS Produções Artísticas. Mas, a gravadora foi criada ainda em 2007. Fernando Fakri soube também construir Sorocaba, um personagem carismático e excêntrico. Até quando fala como empresário ele se recria, troca o chapéu por um boné. O sorriso largo e a postura levemente encurvada são substituídos pelo olhar sério e o porte ereto.

Os artistas sertanejos têm como protocolo iniciar cada apresentação com a "música de trabalho”. Em geral, é uma música do atual álbum (2014 na época), que está tendo boa recepção do público e das rádios. Claro que Fernando e Sorocaba não abrem mão desse formato e a primeira canção que surge é Deixa Falar (2014). Contudo, o recheio do show são as músicas já consagradas: As Mina Pira (2013); A Casa Caiu (2010); Mô (2013); Veneno (2013); Mármore (2014); O Que Cê Vai Fazer? (2013), Madrid, Tenso Demais (2012); Da Cor do Pecado (2009); Verdade (2012); Férias em Salvador (2012); Gaveta (2014); Livre (2014); Bala de Prata (2009); Paga Pau (2009); Pega Eu (2012); Delegada (2010) e Tô Passando Mal (2011). A dupla sertaneja não investe apenas em tecnologia digital. A confluência de sonoridades musicais é outro recuso estratégico para chamar a atenção do público jovem. Instrumentos, como guitarra, violão, baixo, contrabaixo, teclados, sanfona, bateria, gaita, piano e violino, são executados quase que simultaneamente. O resultado é um som eletrificado que transforma o show da dupla sertaneja em um verdadeiro espetáculo de rock rural. $\mathrm{O}$ engenho técnico do show não fica atrás dos grandes concertos do cenário pop rock internacional. Fernando e Sorocaba embalam o animado público do Citibank Hall. Alguns casais chegam a dançar em volta das mesas. O entretenimento promovido pelos artistas parece, às vezes, ser o próprio espetáculo.

Eis que a dupla traz aos palcos a "nova promessa da música sertaneja", receita adotada também por Victor e Leo nos shows com Lucyana Villar. Aliás, a prática de apadrinhamento

\footnotetext{
${ }^{368}$ Entrevista de Ivan Vilela ao autor, 28 de novembro de 2014.
} 
é uma regra do gênero. Sorocaba fez cerimônia na hora de apresentar o pupilo: “A gente tem essa marca de sempre estar tentando inovar. Acho que a música sertaneja se alimenta de novos talentos. A gente sempre tem esse carinho [...], a dupla sertaneja Fernando e Sorocaba, de sempre buscar novos talentos. Isto soma à música sertaneja. A gente acredita que existem artistas que vem a somar e não para dividir o que já tem. Mas tem muita gente boa e a gente sempre traz novos ares para o nosso gênero musical e a música vive disso. De tempos em tempos, ela precisa se renovar dessa forma. E a gente queria trazer um artista que a gente acredita demais". Fernando continua com as honras da casa: "Ele faz um som diferente, um som diferenciado. Tem uma música, inclusive, que está estourada na voz de Zezé Di Camargo e Luciano e que é composição dele". Sorocaba grita um: "Vem para cá fazer essa moda com a gente, Felipe Duran".

O discurso cortês de Sorocaba requer algumas considerações. Tanto na entrevista quanto no show, o artista se refere à dupla sertaneja Fernando e Sorocaba na terceira pessoa do singular. É raro vê-lo comentando "Eu e o Fernando". E, quando usa o sujeito "nós" ou o termo "a gente", logo se corrige: "a gente sempre tem esse carinho [...], a dupla sertaneja Fernando Sorocaba, de sempre buscar novos talentos". Essa terceirização da primeira pessoa do plural é uma tática engenhosa. Primeiro, ele toma a "dupla" como patrimônio pessoal. Mais do que uma patente, "Fernando e Sorocaba" é a sua própria marca. Portanto, somente ele é o porta-voz legítimo dela. São duas personas em um único sujeito: o empresário Fernando e o artista Sorocaba. Os trechos: "a dupla sertaneja Fernando e Sorocaba sempre busca novos talentos" e: "de tempos em tempos ela [a música sertaneja] precisa se renovar dessa forma" são reproduções dos seus anseios empresariais. Seu escritório administra a carreira de Thaeme e Thiago, Lucas Lucco e Marcos e Belutti - nomes da nova música sertaneja. O empresário/artista promove essa atualização do gênero, pois é beneficiado comercialmente pelo sucesso desses. Para Victor e Leo, a realidade é outra. Eles têm que concorrer pela mesma fatia de mercado fonográfico com todos esses artistas. Isso explica a valorização do passado caipira e a aliança com as vozes tradicionais do gênero sertanejo.

A diferenciação é outra prática comum à música sertaneja. Está presente em todas as duplas estudadas. Por exemplo, Fernando Zorzanello reproduz essa distinção, ao apresentar Felipe Duran: "Ele faz um som diferente, um som diferenciado". Victor e Leo, nem se fala. A assessora de imprensa tem até o bordão: "Victor e Leo são artistas diferenciados". Para divulgar Lucyana Villar, Leo diz que está "produzindo um CD diferenciado com a cantora". 
A própria apadrinhada, quando pisa no palco, cita "que a energia daqui é diferenciada". $\mathrm{Na}$ entrevista, Victor repete isso em outras palavras: "creio que a originalidade de nosso som, como algo completamente novo, casou com esta baixa maré para a música sertaneja". $\mathrm{Na}$ realidade, esse tipo de discurso elucida o quão competitivo é o mercado do show business da música sertaneja. Felipe Duran entra no palco e faz seus solos de guitarra. $\mathrm{O}$ aspirante usava óculos escuros e não fazia contato visual com o público. O termo folk teve boa adesão à nova música sertaneja: "Sertanejo folk de Felipe Duran é a nova aposta do cantor Sorocaba"369. Victor Chaves e Felipe Duran gostam de frisar que fazem sertanejo folk. Na prática, é mais uma nomenclatura mercadológica para distingui-los. A guitarra elétrica foi introduzida no gênero por Leo Canhoto e Robertinho e Milionário e José Rico. Nos anos 1970, o rock da Jovem Guarda foi abraçado pelos sertanejos. Portanto, os fortes acordes da guitarra elétrica não são nenhuma novidade à música sertaneja.

Enquanto Fernando Zorzanello e Felipe Duran prosseguiam com o espetáculo, Sorocaba deixava o palco pela terceira vez. Da mesma forma, Leo Chaves também faz uso desse recuo. A conduta de abandono temporário da primeira voz na cena tem uma explicação estratégica: o canto operístico em alto vibrato, o uso do falsete e o elevado volume da voz no refrão agridem as cordas vocais. Esse desgaste da voz afetou Zezé Di Camargo. Em 2007, o cantor foi diagnosticado com um cisto congênito nas cordas vocais e teve que revertê-lo por cirurgia. Sorocaba tem também outros motivos para "poupar" a voz: em setembro de 2014, revelou à imprensa que, em 2010, enfrentou um câncer na tireoide. O tratamento para curá-lo dispensou o uso de quimioterapia, mas lhe custou um pouco de rouquidão na voz. Em entrevista para o programa Domingo Espetacular, da TV Record (exibida em 07 de setembro de 2014), Sorocaba disse que: “ainda ter medo de perder a voz”. Na atualidade, o responsável central pelo êxito financeiro são os shows ao vivo. O sucesso econômico com altas vendagens dos discos ficou no passado do gênero. A gravação em estúdio poupava a voz dos cantores. Hoje, a voz ao vivo é o próprio ganha pão dos sertanejos.

Na canção $O$ Que Cê Vai Fazer?, Zorzanello apareceu em um piano colorido psicodélico. Sorocaba foi além e tocou violão, gaita e violino. Os demais instrumentos foram conduzidos pelos cinco membros da banda. A articulação instrumental não era fixa: a gaita surgia com a guitarra, o violão junto do piano ou o violino associado à guitarra. Outro artefato central era o microfone. $\mathrm{O}$ formato auricular deixava a movimentação dinâmica, dentro e fora

\footnotetext{
${ }^{369}$ Portal de notícias G1/Globo: Sertanejo folk de Felipe Duran é a nova aposta do cantor Sorocaba, 17 de julho de 2014.
} 
do palco. Na lateral e no centro do palco, os monitores LED mixavam cores, luzes, imagens e videoclipes da dupla. O cenário acompanhava a roupagem instrumental e o repertório musical da dupla. Na faixa "Tenso Demais", outra figura cênica tomou conta do palco: dois personagens caricaturais dos artistas surgiram com as cabeças recobertas por látex; pulavam e dançavam ao lado dos artistas e brincavam com a plateia. Sorocaba os empurrava, exclamando: "Some daqui, desgraça". O público soltava gargalhadas e se divertia com o desempenho teatral dos bonecos. O voto de trazer música aliada à diversão aos fãs é efetivado durante duas horas. Só que Sorocaba queria um pouco mais. Enquanto o parceiro ficava no palco conversando com a plateia, o caubói desceu as escadas e foi para o centro do auditório. A histeria tomou conta do público. Escoltado por dezenas de seguranças, Sorocaba levou junto o violão. Os espectadores, antes sentados nas mesas reservadas, passaram a se aglomerar em torno do artista. Juntos, cantaram Gaveta, Pais e Filhos (Legião Urbana) e Domingo de Manhã (Marcos e Belutti). Em seguida, Fernando se juntou à galera. Por quinze minutos, os dois continuaram o show ali. A interação corporal "no meio da galera" é comum à dupla sertaneja. É um valoroso recurso cênico, pois cria empatia do espectador com o ídolo. Sorocaba se esforça para institucionalizar o carisma no corpo a corpo, junto do seu público. E a estratégia dá certo. $\mathrm{O}$ artista acena humildade e disposição aos seguidores, além do contato corporal tornar a figura cênica mais palpável ao público. Cada artista sertanejo estabelece um pacto afetivo particular. Por exemplo, Victor e Leo não abandonam o palco. Porém, Leo instiga as devotas a aguentarem longas horas no estacionamento interno, em condições inóspitas. As vencedoras da "maratona" podem abraçá-lo e ouvir seus agradecimentos.

O caubói prossegue: "Obrigado, galera! Essa música que vou tocar agora [Pais e Filhos, Legião Urbana] traz uma mensagem [É preciso amar as pessoas como se não houvesse amanhã. Porque se você parar para pensar. Na verdade não há] que a gente gosta de dividir com a galera. Tem uma mensagem muito bonita e a trazemos em todos os shows". Há todo um arsenal de cerimônias e convenções nos shows da música sertaneja: os agradecimentos, os trechos com as modas de viola, as revelações de uma "nova promessa" e também (por que não?) o discurso em prol do "amor e do bem". Tal como Leo, Sorocaba gosta de deixar uma mensagem cívica, religiosa ou moral para seus seguidores: "Devemos amar aos outros como a nós mesmos. Essa é a regra do jogo. Essa é a regra da vida. Ajude a pessoa que está ao seu lado. Devemos ter amor no coração". Sorocaba não deseja apenas tocar o coração dos fãs. Ele pede o apreço: "Quem gostou disso faz barulho que eu quero saber". A personalidade peculiar de Sorocaba cativa o espectador. Em um momento, ele acena simplicidade e em outro, 
extravagância. O sotaque interiorano, quase caricatural, é sabiamente articulado com os acessórios espalhafatosos e caros. Discretamente, Sorocaba voltou ao palco pela lateral do camarote inferior, enquanto Fernando distribuía algumas paletas às fãs e gritava: "Tá bom demais aqui. Vamô tocar modão? Vocês que mandam!”. A música Boate Azul (Milionário e Zé Rico) ganhava, então, o coro do auditório. Depois, Fernando "escalou", literalmente, a escadaria central do palco e retomou sua posição.

A essa altura, já era possível analisar o público da dupla sertaneja. Tanto em Terra Country Interlagos quanto no show do Citibank Hall, notei a presença quase igualitária dos dois sexos. As mulheres eram bonitas, jovens e elegantes. Tinham entre 18 e 35 anos. Vestidas com minivestidos, as curvas corporais e os cabelos longos chamavam a atenção. Estavam bem-maquiadas e usavam salto alto. Uma parcela estava acompanhada de parceiros afetivos, porém, não foi raro vê-las em turmas de amigas ou até mesmo sozinhas. Os grupos familiares só foram vistos no primeiro show, ainda assim, eram a minoria. Geralmente, sentavam-se nas mesas ou nas áreas VIP's. Entre os homens, a diversificação de idade foi maior. Os mais jovens acompanhavam os amigos ou iam sozinhos. Os quarentões ou cinquentões sempre estavam ao lado de uma dama. Vestiam-se iguais ao cantor: camisa social, fivela, bota e chapéu de caubói. Essa cota masculina e adulta encontrada no show está longe de ser casual.

A modernização da agricultura e o êxito do agronegócio nacional foram os corresponsáveis pelo sucesso econômico de um novo estrato-médio da população brasileira. Sorocaba soube retraduzir tudo isso em seu personagem: o homem interiorano que ficou rico e moderno, mas que encontra na tradicional música sertaneja o elemento socializador dessa nova experiência social. Fernando Fakri de Assis foi criado em meio ao agrobusiness do interior paulista, em um berço social coberto por ouro. Inclusive, a família empreendedora atuou nesse ramo, estimulando precocemente o ethos capitalista no filho. Na faculdade de agronomia, a "música falou mais alto", mas o herdeiro aceitou a herança ${ }^{370}$. Então, decidiu reinvestir o patrimônio em capital tecnológico/artístico e o aplicou no mercado do show business sertanejo. O empresário elaborou o personagem Sorocaba com caracteres físicos e psicológicos semelhantes aos vistos entre seu público. Hoje, a dupla "Fernando e Sorocaba" é o slogan de uma marca musical, sobretudo empresarial de Fernando Fakri de Assis: "Eu gosto muito do que eu faço, hobby e trabalho acabam se misturando. Eu gosto muito disso, meu

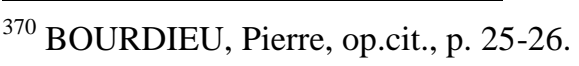


trabalho é muito prazeroso para mim. Eu sou incansável atrás de procurar uma música que seja popular e que tenha um diferencial, vivo 24 horas em função de música, é como se eu trabalhasse 24 horas por dia. Eu e o Fernando, assim como todo o escritório, gostamos de por a mão na massa. Acho que esse é um dos grandes motivos do nosso sucesso"371.

Em comparação com as seguidoras de Victor e Leo, Fernando e Sorocaba têm um público misto, com variações de gênero, faixa etária e grupo social. A estrutura do espetáculo justifica a assimetria: Fernando e Sorocaba oferecem um show-balada. A música é só um dos componentes da apresentação. A sofisticada tecnologia e a temática festiva atraem também um público jovem, urbano e diversificado. A moderna balada pop sertaneja aliada à diversão, entretenimento e inovação audiovisual desperta o interesse desses espectadores. Os moços se sentem instigados, porque encontrarão música moderna e a oferta de belas mulheres solteiras que vão ao evento. As próprias músicas que embalam o show ilustram esse jogo sexual vivido pelo público. Se Fernando e Sorocaba não têm status de beleza, como Victor e Leo, eles participam do jogo erótico de outra forma: vestem calças de couro ou jeans justíssimas, destacando a região dos órgãos genitais. No entanto, a sensualidade viril vai sendo dosada na personalidade de cada um: Fernando Zorzanello tem o ar de roqueiro tímido e músico concentrado, já Sorocaba é desengonçado, tem semblante de caipirinha bobo e ingênuo. Claro que as letras do cancioneiro confessam outra direção, especialmente, o tom machista da valorização estética da bebedeira e da diversão barata com as mulheres. No palco, tudo isso fica encoberto: "Meu segredo como compositor é ter conseguido desenvolver esse filtro popular, eu não nasci sabendo. Minhas primeiras composições eram bobinhas demais, depois passei a pirar demais e errar a mão. Levou tempo pra me ajustar e desenvolver essa espécie de controle. Os acertos vêm quando esse processo deixa de ser racional e passa a ser natural"372.

Victor e Leo lidam com outra audiência, centralizam a tensão sexual para si e não a partilham com outro competidor masculino. O púbico feminino vai até o show querendo vêlos, abraçá-los ou tocá-los. Os produtores dos músicos sabem disso e até limitam o atendimento no camarim, algo que Fernando e Sorocaba fazem de prontidão em menos de uma hora. Essa restrição aumenta o imaginário afetivo. Para compensar a ausência de contato físico direto, elas mobilizam estratégias de aproximação, cercando os irmãos no estacionamento do local. Ali, enfrentam uma rotina quase humilhante para acessá-los. No final da maratona, Victor sequer abaixa o vidro do automóvel para atendê-las. Elas não veem

\footnotetext{
${ }^{371}$ Entrevista de Sorocaba ao portal Universo Sertanejo, 13 de maio de 2013.

${ }^{372}$ Idem, 13 de maio de 2013.
} 
tanto problema nisso, porque o personagem poeta só existe enquanto está no palco. Leo é quem as sacia, com seu porte atlético de $1,94 \mathrm{~m}$ e o corpo moreno. Infelizmente, não pude coletar itens como classe social e nível de escolaridade dos dois públicos. Os dados do IBOPE (2013) revelam o óbvio: o público sertanejo pertence à classe C, está no Centro-Sul brasileiro, tem entre 25 e 35 anos e nível escolar fundamental ${ }^{373}$.

Após os solos de guitarra de Sweet child O'mine, Fernando e Sorocaba agradeceram aos seis músicos da banda: Marcos César da Silva (baixo), Dudu Mafra (teclado), Rodrigo Alison (bateria), Betinho Vieira (violino/violão), Paulo Perin (guitarra) e Celso Nascimento (violão). Sorocaba aproveitou e falou mais da origem social: "Eu sou nascido aqui e poucas pessoas sabem disso. Não nasci em Sorocaba não. Sou nascido aqui na região de Santo Amaro. Fui criado em Sorocaba, mas nasci na zona sul de São Paulo. Quem é da zona sul? Palma para nós!". E ainda brincou com o companheiro que "nasceu muito longe" e procura conterrâneos entre o público. Também relembrou as letras que escreveu e "estourou na voz do jovem cantor sertanejo Luan Santana". De quebra, cantou trechos de Você Não Sabe O Que É o Amor e Meteoro da Paixão, ambas de sua autoria, mas popularizadas pelo astro teen da música sertaneja atual. Sorocaba não esconde seu orgulho por essa boa empreitada comercial. Na faixa Tô Passando Mal (2011), despediram-se do público. Finalmente, Sorocaba retirou o chapéu que recobria parcialmente seus olhos. Em seguida, os músicos foram receber amigos e familiares no camarim. Oficialmente, o atendimento ao público já havido sido feito no dia anterior. Mesmo assim, por quarenta e cinco minutos, eles receberam algumas admiradoras e as presentearam com rosas; deram entrevista à rádio paulistana Nativa FM. A rádio Gazeta FM foi umas das patrocinadoras do evento. Sorocaba trocou o chapéu por um boné. Em outras ocasiões, ele justificou o fato de não aparecer com a cabeça descoberta: considera seu cabelo "ruim demais". Foi carismático e solícito, tirou foto e deu autógrafo, enquanto Fernando segurava uma bebida energética e atendia às fãs na fila de espera. Às $1 \mathrm{~h} 45$, encerraram o atendimento e foram para uma confraternização na casa de Fernando Zorzanello.

Fernando Fakri de Assis "Sorocaba" conhece como ninguém as artimanhas do novo mercado da música sertaneja, transforma o espetáculo em uma balada tecnológica e a música

\footnotetext{
${ }^{373}$ Infelizmente, houve pouco tempo hábil no mestrado para elaborar e aplicar questionários junto ao público. O estudo de recepção da música sertaneja é um capítulo importante a ser feito. Espero que, no futuro, essa ausência possa ser preenchida por novas pesquisas acadêmicas sobre o tema.
} 
em diversão e entretenimento. Isso explica as diferentes tribos musicais que são atraídas ano a ano para seus shows:

Quem investir em entretenimento de qualidade se dará bem. O sertanejo é, sem sombra de dúvidas, o gênero que mais está trazendo bom entretenimento pra esse país. Nós levamos outros tipos de entretenimento aos palcos além da boa música, usando uma pitada de tecnologia, mágica, movimentação. Gostamos de surpreender as pessoas e isso já virou uma marca da dupla. O sertanejo está disparado na frente dos outros estilos. $\mathrm{Na}$ minha visão, ele vai permanecer em nível muito alto e vai ser a principal música do Brasil ainda por muitos anos. Acredito também que o nível de exigência do povo vai aumentar, e as duplas e as festas terão que acompanhar esse desejo por coisas melhores. Para mim, quanto mais gente boa fizer sucesso, mais o mercado vai expandir, e eu me aproveito dessa maior abertura. Vai haver mais festas, mais eventos, mais procura por shows, e isso reflete em todos. Se eu fizer minha parte, Victor e Leo fizerem a deles, Michel Teló fizer a dele, Jorge e Mateus fizerem a deles, só vai ser bom. Isso é algo que eu acho importante que as pessoas entendam, e muita gente eu sei que não enxerga $\operatorname{assim}^{374}$.

O investimento em "entretenimento de qualidade", citado pelo empresário, é a principal aposta de modernização da música sertaneja. O mercado musical tem colhido bons frutos comerciais adotando essas estratégias de atualização e manutenção do públicoconsumidor. Por um lado, o gênero acolhe os apreciadores tradicionais e, por outro, abocanha um novo quinhão: os jovens urbanos recém-chegados à classe-média, que integram o sistema de ensino universitário. Os dizeres de Sorocaba de que "o sertanejo é o gênero que mais está trazendo bom entretenimento para esse país" e o conselho de que "quem investir em entretenimento de qualidade se dará bem" são reveladores. Tanto os artistas sertanejos quanto a indústria fonográfica estão atentos às transformações do cenário cultural, social e econômico brasileiro. Hoje, o êxito comercial do show business sertanejo depende dos auditórios superlotados e dos milhares de ingressos vendidos. O entretenimento de qualidade é cumprido, mas a música em si é apenas um mero apetrecho de fundo da balada pop sertaneja. O investimento tecnológico digital combinado ao entretenimento são os capitais artísticos definidores e diferenciadores desse novo mercado. Só que nessa "jogada", são poucos os artistas sertanejos que têm esse "curinga" nas mãos para bater boa aposta. Sorocaba, no entanto, tem o baralho completo: "Nós levamos outros tipos de entretenimento aos palcos. Além da boa música, usamos uma pitada de tecnologia, mágica e movimentação" ${ }^{275}$. Quando deixa de lado o chapéu de caubói e o substitui pelo boné, a personalidade carismática e

\footnotetext{
${ }^{374}$ Idem, 13 de maio de 2013.

${ }^{375}$ Entrevista de Sorocaba ao portal Universo Sertanejo, 13 de maio de 2013.
} 
ingênua do personagem Sorocaba cede lugar ao perfil empresarial e competitivo de Fernando Fakri de Assis. Clinicamente, prevê que: "o nível de exigência do povo vai aumentar e as duplas e as festas terão que acompanhar esse desejo por coisas melhores [...] quanto mais gente boa fizer sucesso, mais o mercado vai expandir, e eu me aproveito dessa maior abertura"376. A maior estratégia usada por Sorocaba no mercado musical sertanejo é a diferenciação tecnológica. E vigor para inovar não lhe falta. Ele sabe que essa expansão frenética de novas duplas sertanejas lhe beneficia. Se por um lado, o artista "diferenciado" se destaca na competição com os novatos, por outro, ele pode oferecer seu escritório para gerenciá-los.

Esse “desejo por coisas melhores do público" que deverá ser acompanhado pelas festas e duplas não é um conselho, mas sim uma autovalorização da sua própria atuação artística. Porém, adverte seus concorrentes: "Se eu fizer minha parte, Victor e Leo fizerem a deles, Michel Teló fizer a dele, Jorge e Mateus fizerem a deles, só vai ser bom. Isso é algo que eu acho importante que as pessoas entendam, e muita gente eu sei que não enxerga assim"377. Não é à toa que o dueto Victor e Leo seja citado, nem essa indisposição deles em não “enxergarem assim”. De 2007 a 2015, esses foram os maiores competidores do mercado da música sertaneja de Sorocaba. De lá para cá, o teor bucólico e sertanista das composições de Victor Chaves se opuseram às temáticas festivas e o estilo de música feita em quinze minutos de Sorocaba ${ }^{378}$. A especificidade da história social dos quatro músicos confessa uma disputa artística, mas também social. No interior desse microcosmo, Sorocaba investe seu capital econômico nos shows, enquanto Victor imprime seu capital cultural nas composições musicais. Os dois retraduzem essas representações sociais em composições musicais, pleiteando quais dessas são legítimas e devem se impor dentro do gênero. Portanto, esse debate, tanto artístico (tradição versus modernização) quanto social (cultural versus comercial), atravessa a história quase secular da música sertaneja e chega até a atualidade do gênero, como exemplificou o estudo de caso comparativo entre as duas duplas. No próximo item, trago as fotografias do espetáculo de Fernando e Sorocaba.

\footnotetext{
${ }^{376}$ Idem, 13 de maio de 2013.

${ }^{377}$ Idem, 13 de maio de 2013.

378 "Não é um raciocínio frio não, eu me considero alguém caloroso. Minha forma de compor é engraçada. Tem vezes que parece que baixa uma coisa e em 15 minutos sai uma música. 'Paga Pau' foi assim, 'Meteoro' foi assim, saíram em 15 minutos, tudo de uma vez. Já 'Madri', por exemplo, eu levei meses pra terminar. Não há uma fórmula ou um segredo, mas eu acho que se há uma recomendação é de que o compositor busque sempre tentar ser popular, pois a música sertaneja é popular e nunca vai deixar de ser. E ser popular não é ser bobo, falar qualquer coisa, qualquer besteira. Esse equilíbrio é o grande negócio". Entrevista de Sorocaba ao jornalista André Piunti. Fonte: Portal Universo Sertanejo, 13/05/2013.
} 


\section{Não é Barretos não! É São Paulo...}

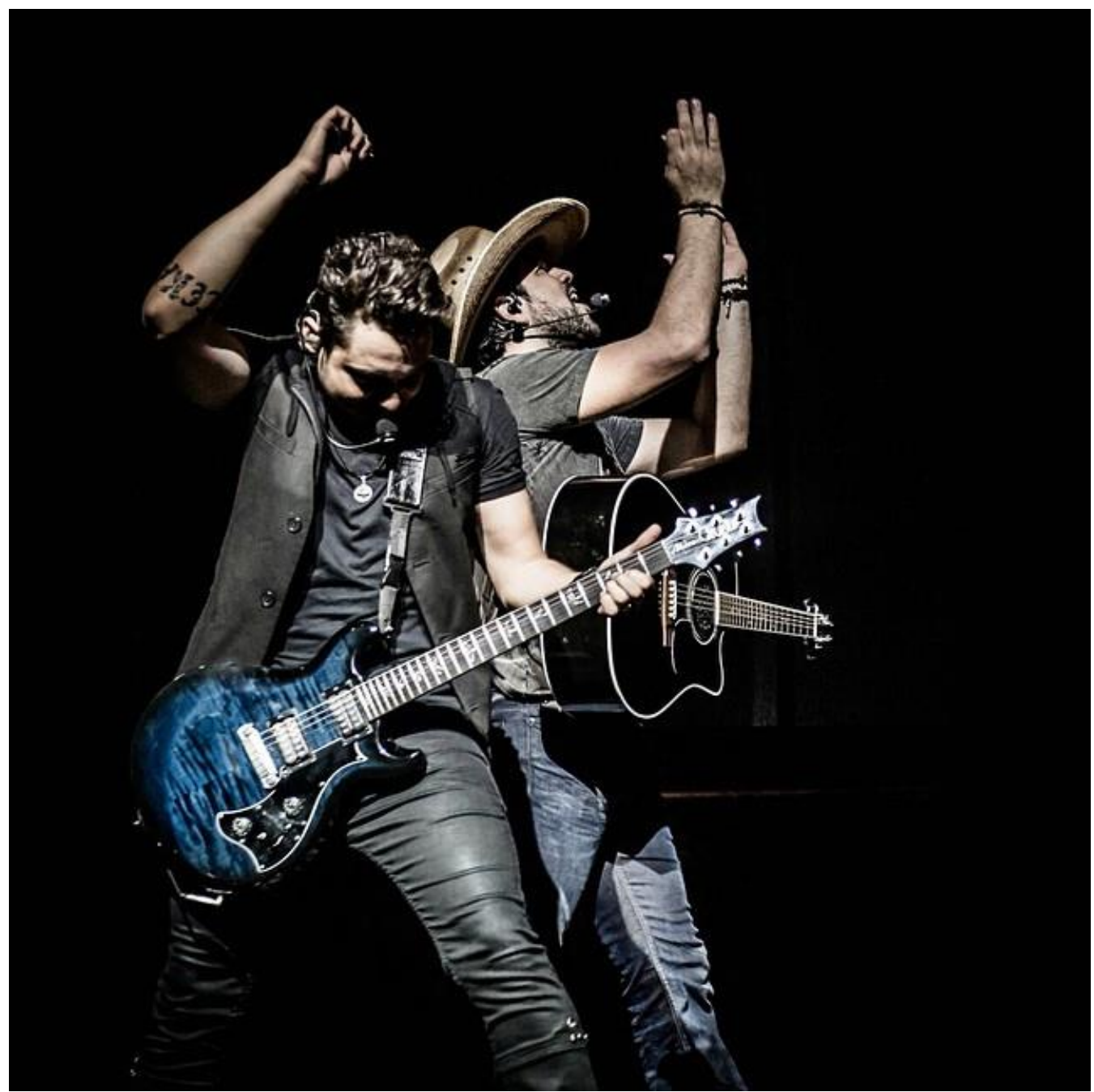

Fernando Zorzanello (à esquerda) tem a postura de um roqueiro: flexiona as pernas e afasta um joelho do outro, levanta o braço direito e apoia a mão esquerda na guitarra, como se estivesse fazendo um acorde. $\mathrm{O}$ movimento ressalta o tônus das pernas e os músculos dos bíceps tatuados. Veste colete e calça de couro. Os cabelos castanhos têm algumas luzes loiras. O porte de Sorocaba (à direita) é menos tensionado: uma perna próxima da outra, com os braços erguidos e a mão esquerda toca no pulso do braço direito. $\mathrm{O}$ violão é apoiado em um suporte deixando os punhos soltos. Veste camiseta simples e calça jeans. A cabeça é erguida e os olhos são fechados. A moldura do rosto é contornada pela barba e pelo chapéu de caubói. A postura corporal solta facilita a movimentação do vocalista pelo cenário, enquanto o outro se mantém atento no instrumento. $\mathrm{O}$ violão em cordas de aço concorre com dezenas de outros instrumentos eletrificados durante o show, sobretudo a guitarra. A dupla não tem uma identidade musical definida. As sonoridades do rock, pop, sertanejo, country e da balada eletrônica são bem-vindas. Essa aposta de "um pouco de tudo" funciona para o público misto dos artistas. Elementos tradicionais e modernos convivem no mesmo espaço. As modas de viola, por exemplo, são acompanhadas por solos de guitarra e o público não reclama.

Foto: divulgação. 


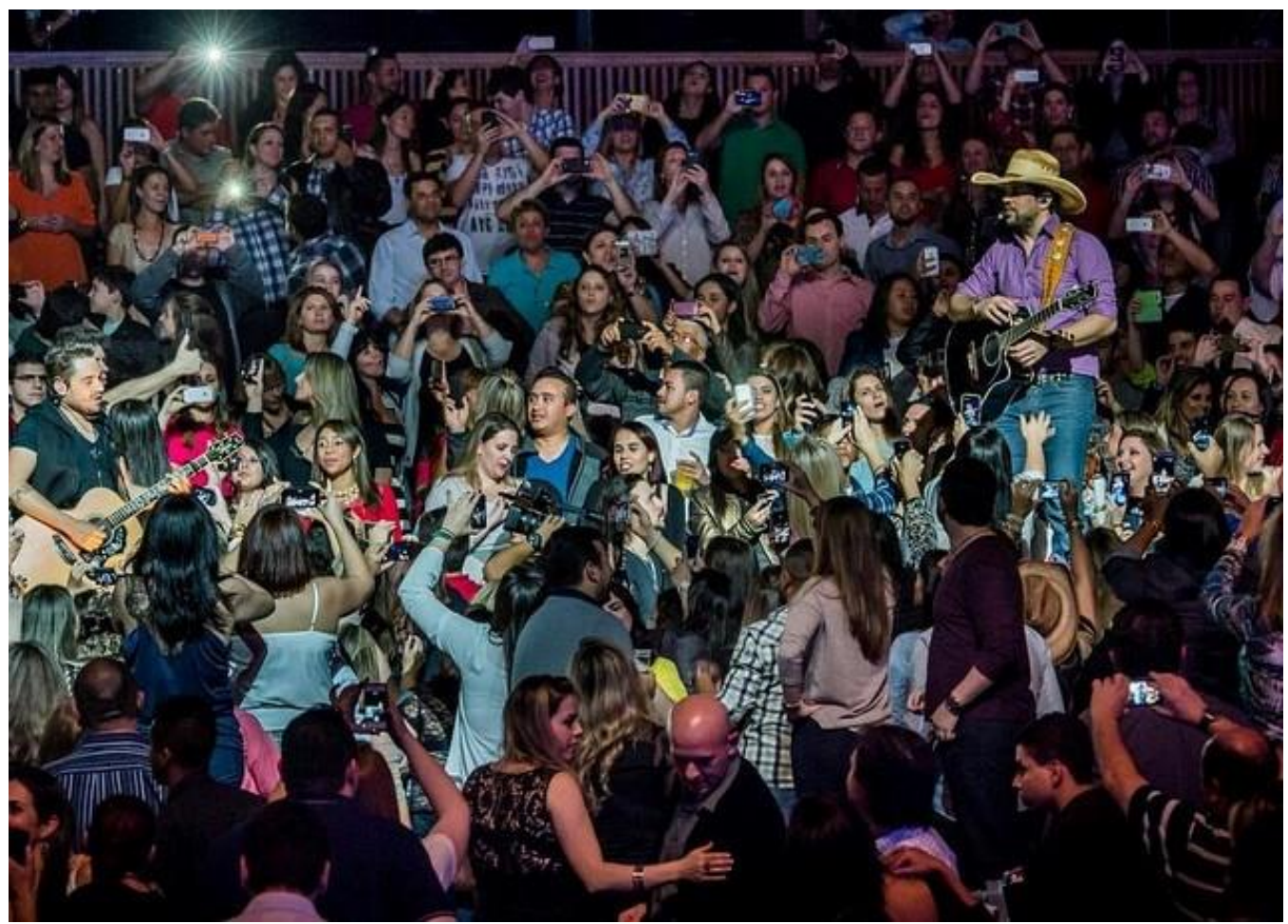

Fernando (à esquerda) e Sorocaba (à direita) no "meio da galera" do Citibank Hall. Substituir o palco pelo auditório é um dos muitos recursos cênicos promovidos pela dupla. Na prática, essa estratégia de interação fortalece os laços de empatia com a plateia, sugerindo uma atitude humilde do ídolo com o seu público. À medida que a hierarquia existente entre o palco-plateia é dissolvida, a conexão emocional e dramática do artista se intensifica. É o momento de registrar aquela mensagem de valorização do bem e do amor. Sorocaba é responsável por enredar o discurso e o protagonista carismático da apresentação. Ele carrega o violão apenas como adereço. O destaque do personagem está na caracterização de caubói texano. A tarefa de instrumentista fica restrita a Fernando. Foto: divulgação.

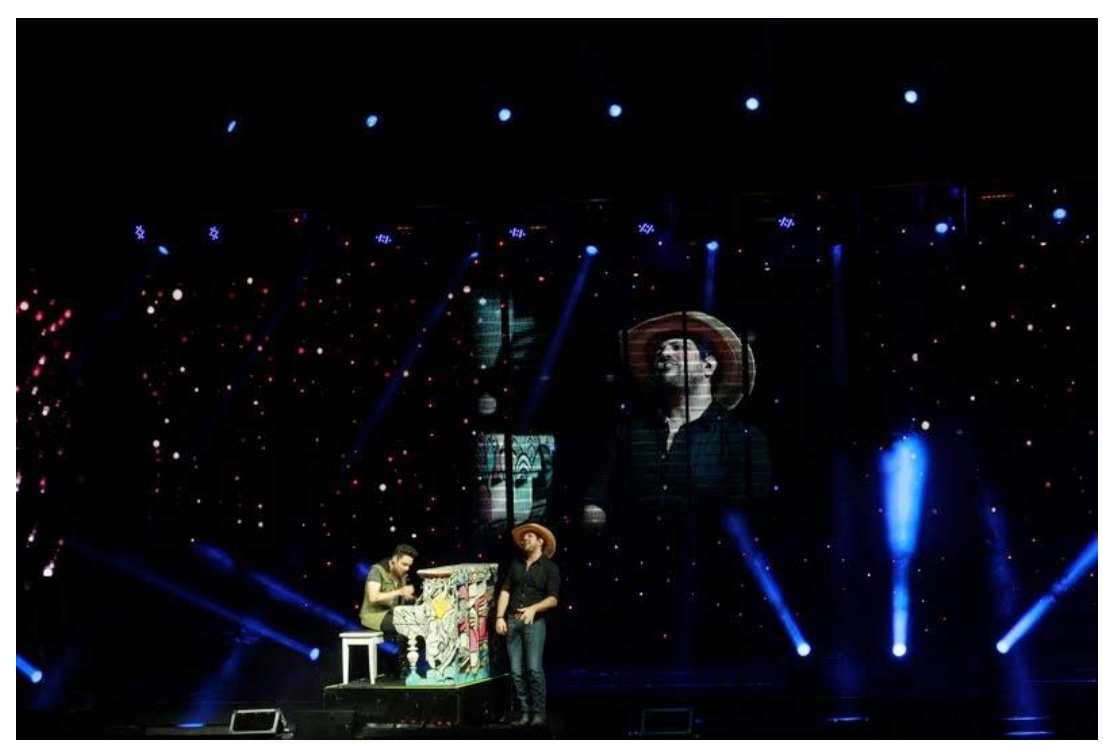

A qualidade técnica promovida pela dupla faz uma simples apresentação se transformar em um verdadeiro "show" de efeitos ilusionistas, pirotécnicos, digitais e acrobáticos. Enquanto Zorzanello fica em cima do piano psicodélico, os monitores LED espelham as imagens de Sorocaba por todo o cenário. Foto: Rosa Marcondes. 


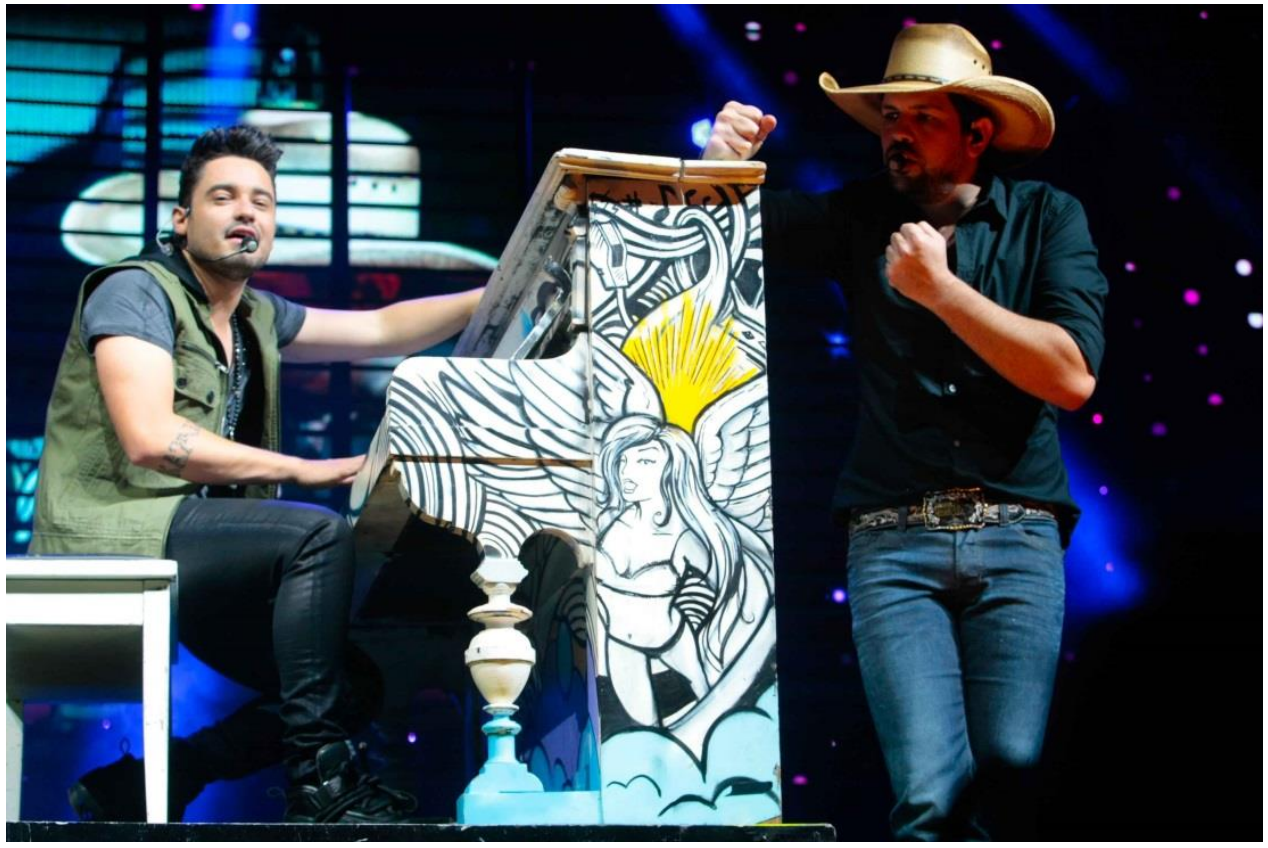

Fernando Zorzanello (à esquerda) nunca abandona as mãos do instrumento e nem o visual de roqueiro pop. Já Sorocaba (à direita) apenas o observa enquanto encena o protagonista: um caubói viril, corajoso e cheio de personalidade que sabe fazer a "lida" do gado e do público com as mãos. A calça de couro apertada de um e o jeans justo ao corpo do outro são estratégias do show business. O contorno saliente das pernas, quadris, glúteos e genitálias é comum à música sertaneja. Tem duas funções: apelo erótico ao público feminino e a estereotipação masculina do peão de boiadeiro. O piano psicodélico tem um desenho sugestivo: uma mulher provocativa e seminua, mas com asas de um anjo. Na prática, esse paradoxo também é encenado nos palcos. Os dois usam roupas sensuais, provocativas e extravagantes, mas os traços da personalidade são outros: Fernando é o músico tímido e focado e Sorocaba é o cantor descontraído, bobo e desajeitado. Foto: Rosa Marcondes.
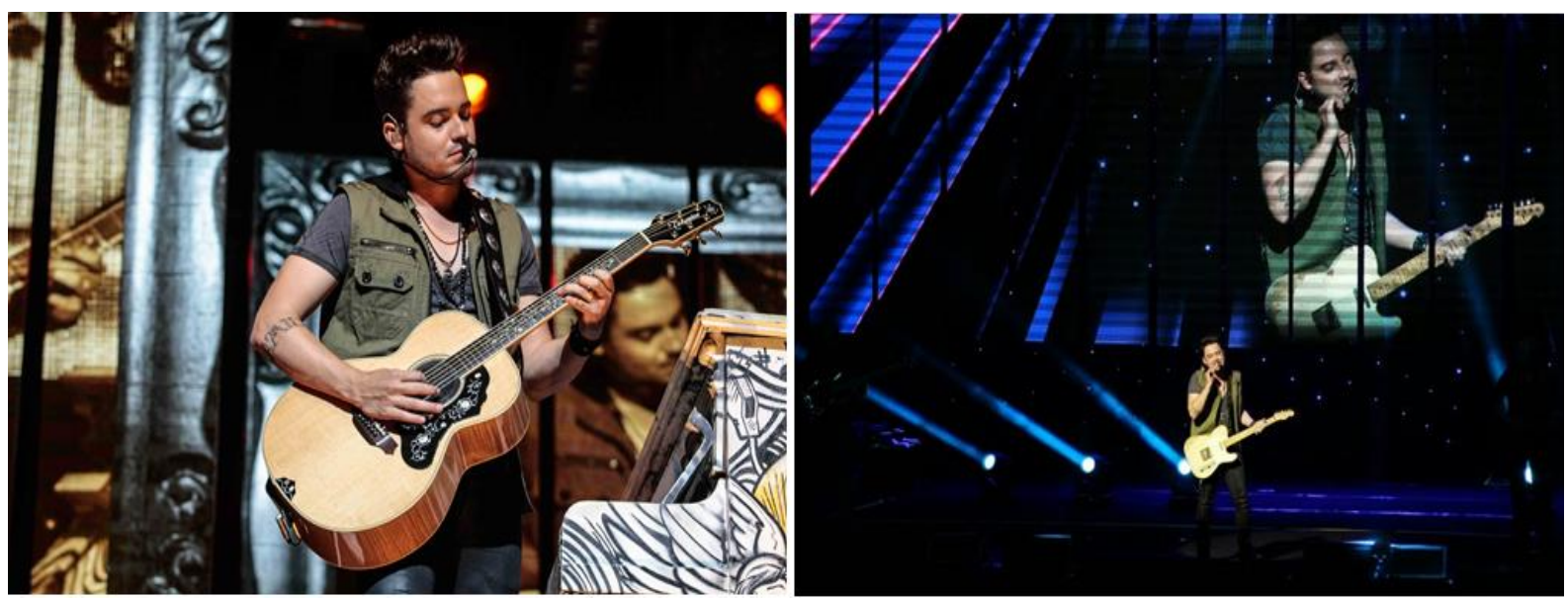

Fernando Zorzanello só tem um pouco de centralidade na apresentação se Sorocaba recuar ao bastidor para mirabolar suas engenhocas. O multi-instrumentista vem de uma família humilde e teve uma trajetória social repleta de percalços. Mas, os tempos difíceis de estrada musical foram proveitosos. Em uma única apresentação, ele toca violão, guitarra, piano e bateria. É o responsável pelo trecho dos "modões de viola". Nos palcos, apresenta-se, às vezes, como primeira voz, sobretudo, quando é preciso poupar a voz do parceiro. O visual moderno é mais uma tentativa de trazê-lo em evidência do que parte da personalidade. Foto: Rosa Marcondes. 


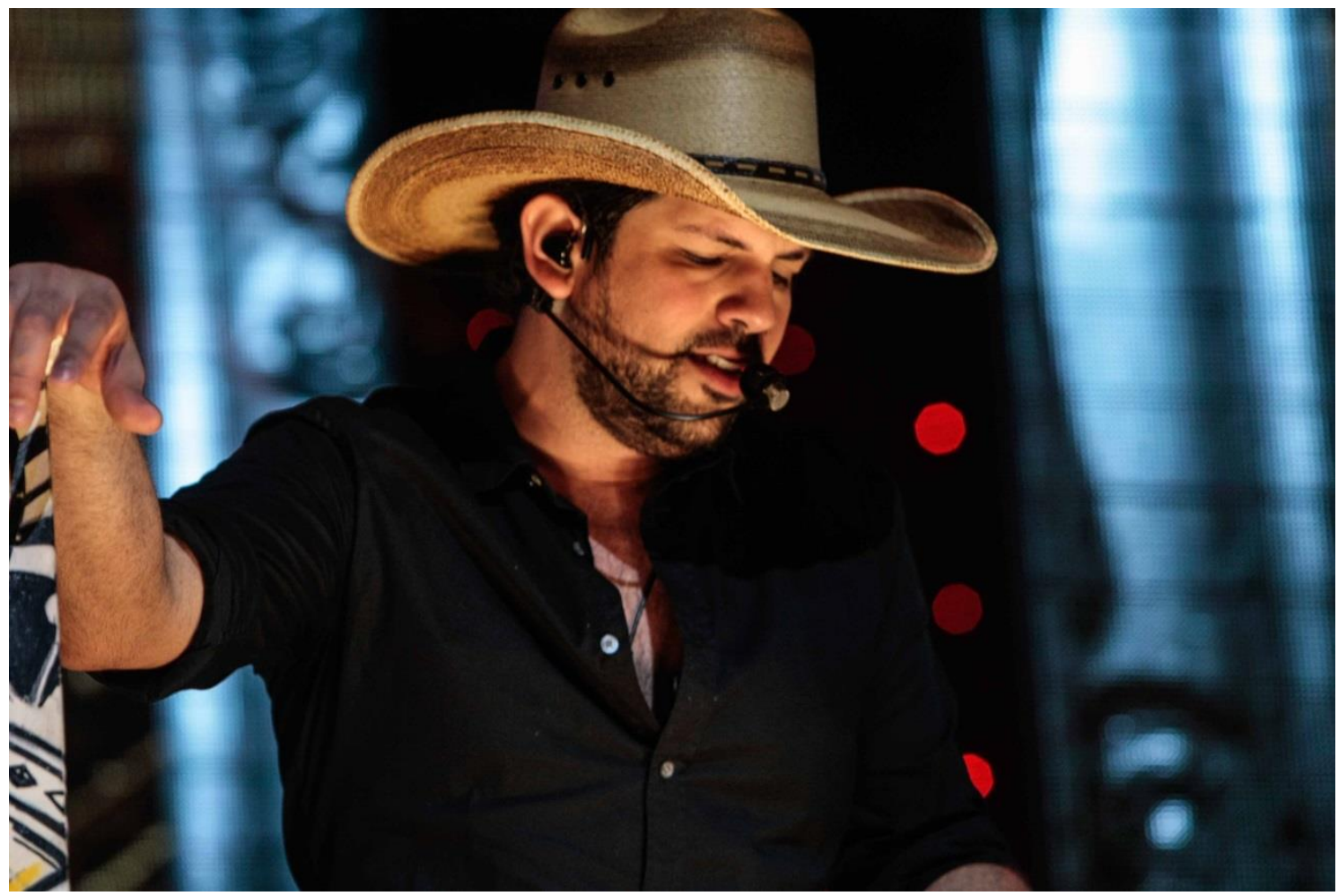

O show da dupla não é feito somente de balada. Sorocaba sabe a hora de dramatizar o caubói romântico. Na canção A Verdade, o cantor encena os dilemas de um homem apaixonado que sofre com a relação amorosa malacabada. A personalidade do personagem acompanha a canção. A aba do chapéu recobre parcialmente os olhos, auferindo-lhe um ar misterioso e sedutor. Ultimamente, tem aderido ao visual de barba, mas nunca dispensa o uso de maquiagem. A técnica teatral de manter o olhar entreaberto e mirado para baixo é um modo de trazer as lembranças afetivas à tona na narrativa. A mão direita apoiada no piano sugere o desalento do ator, pois não há nada que trará a mulher amada de volta, apenas as recordações do passado. Até hoje, o gênero romântico é essencial aos músicos sertanejos. A temática amorosa é solicitada pelo público mais tradicional. Como homem de negócios, Sorocaba atende a todos os gostos dos seus consumidores. Foto: Rosa Marcondes.
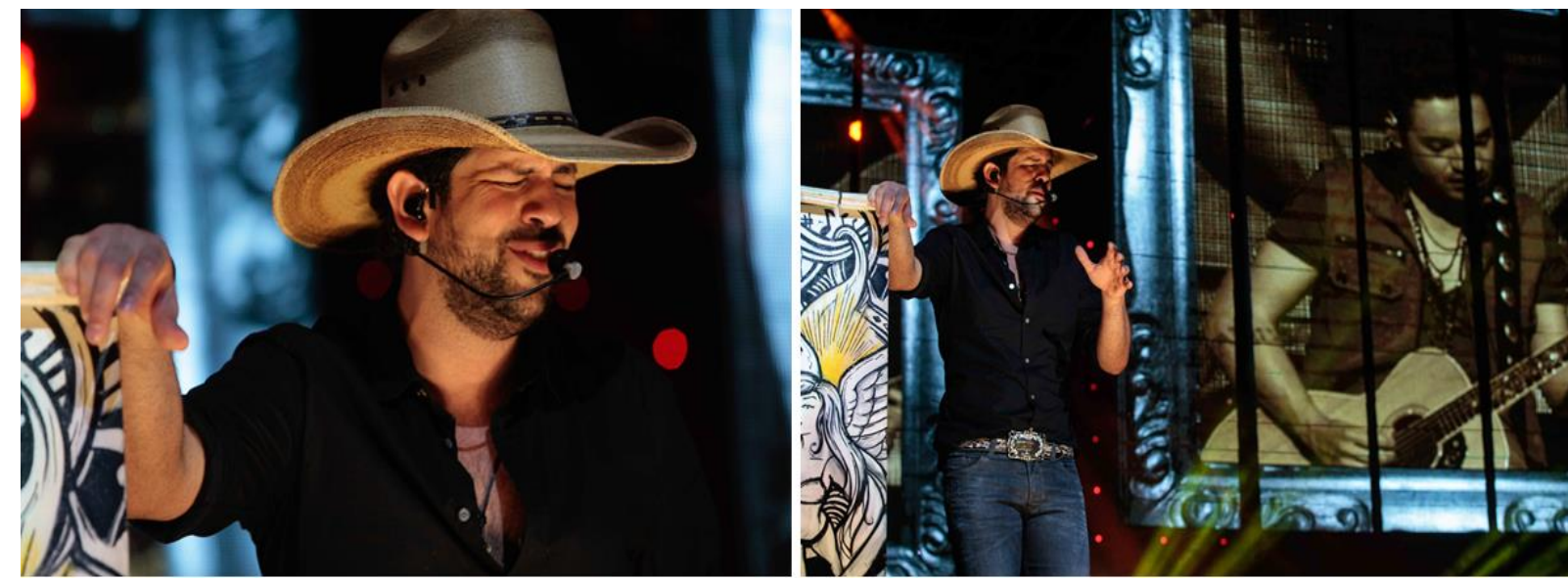

A encenação fica mais dramática e o protagonista simula o choro (à esquerda). Em seguida, mantém a posição da cabeça e usa o movimento das mãos para acentuar o melodrama (à direita). Contudo, a excentricidade de Sorocaba nunca é abandonada. O monitor digital mostra a imagem de Fernando apoiado no violão apenas como músico, deixando o papel de intérprete da cena apenas para o caubói. Foto: Rosa Marcondes. 


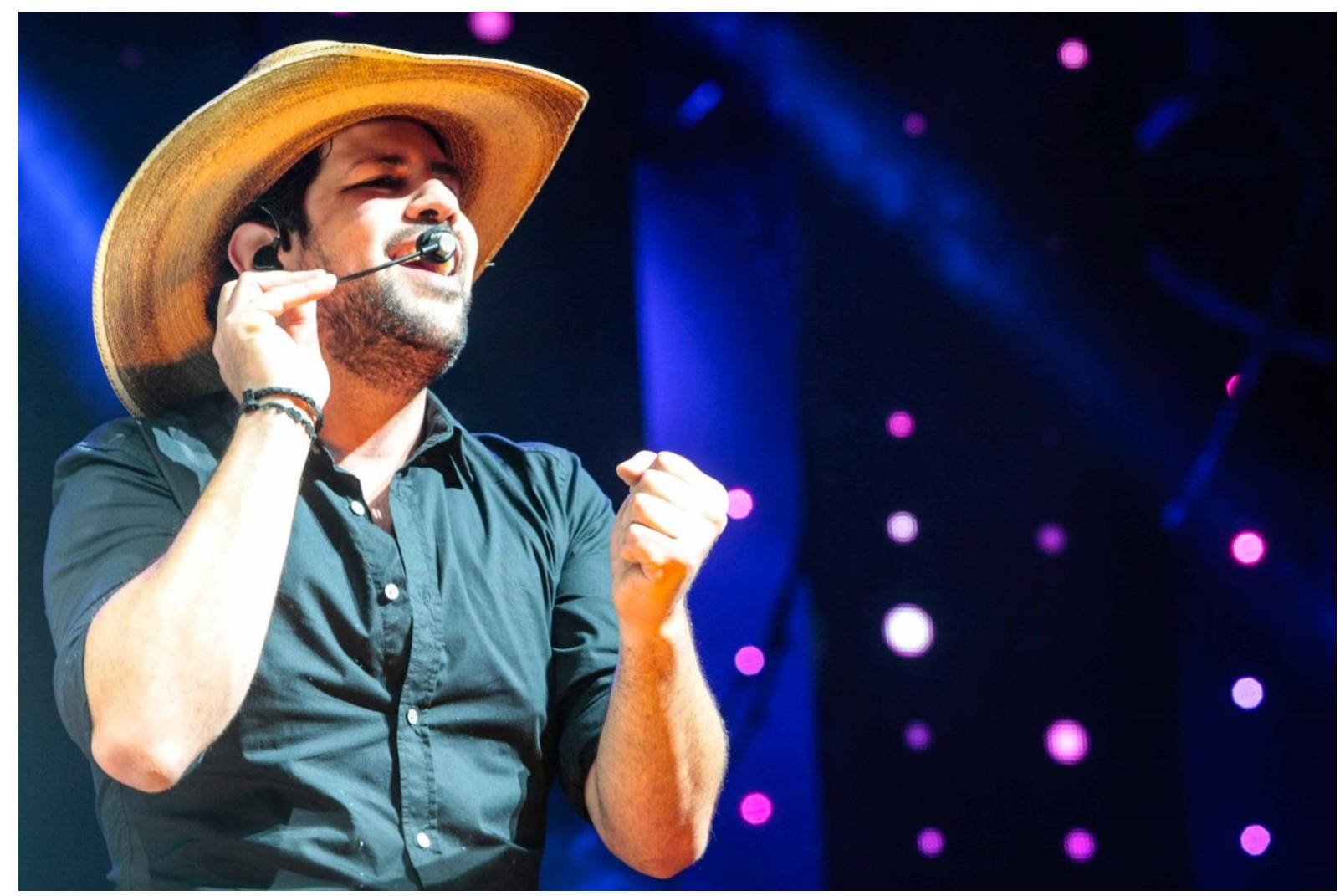

O trecho da canção Livre, "Estiloso na fazenda e selvagem na cidade", exemplifica a personalidade dúbia de Sorocaba. No show, essa dualidade está presente no modo como Sorocaba conduz as narrativas. Para o estilo romântico, investe no apelo dramático. Entretanto, se o enredo for animado, embala o corpo e anima o público para dançar. Foto: Rosa Marcondes.
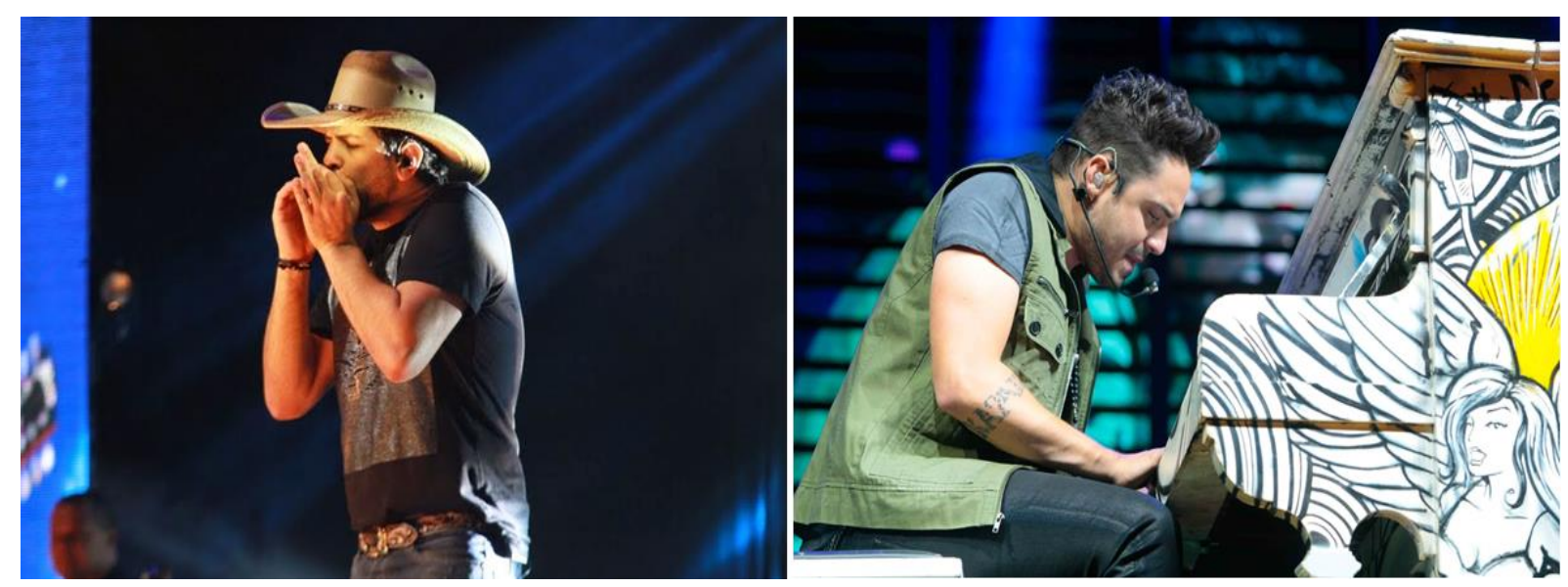

O caubói (à esquerda) exibe seus dotes instrumentais no Citibank Hall. Uma hora usa a gaita, violino, banjo de show e violão. Na realidade, os instrumentos conduzidos por ele são apenas artefatos cênicos. No meio de uma mesma música, o cantor pega a gaita ou o violino, faz umas notas por dois minutos, o público aplaude e Sorocaba se concentra de novo no personagem. Nos Estados Unidos, os concertos de country repetem a mesma fórmula. A primeira voz ganha renome, pois aponta à plateia que também é um mestre instrumental. Aqui, quem faz o trabalho musicista é Fernando (à direita). Em nenhum momento, ele deixa o instrumento à parte. Foto: Rosa Marcondes. 

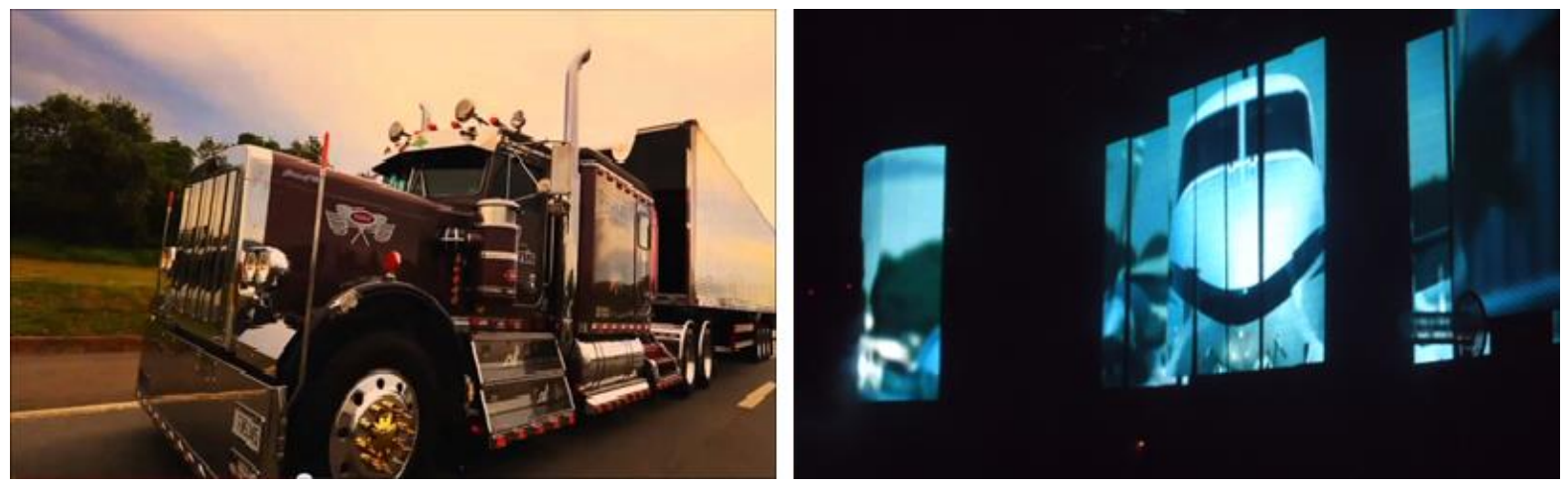

À esquerda, o caminhão dos músicos, patrocinado pela Chevrolet para o clipe Livre. Em 2015, além de fazer parte da turnê de shows, foi usado pela dupla para a campanha publicitária do posto de gasolina Ipiranga. Foto: divulgação. À direita, o avião que aterrissa no palco do Citibank Hall. A tecnologia pode ser em 3D, mas o avião de verdade é de Sorocaba. Foto: do autor.
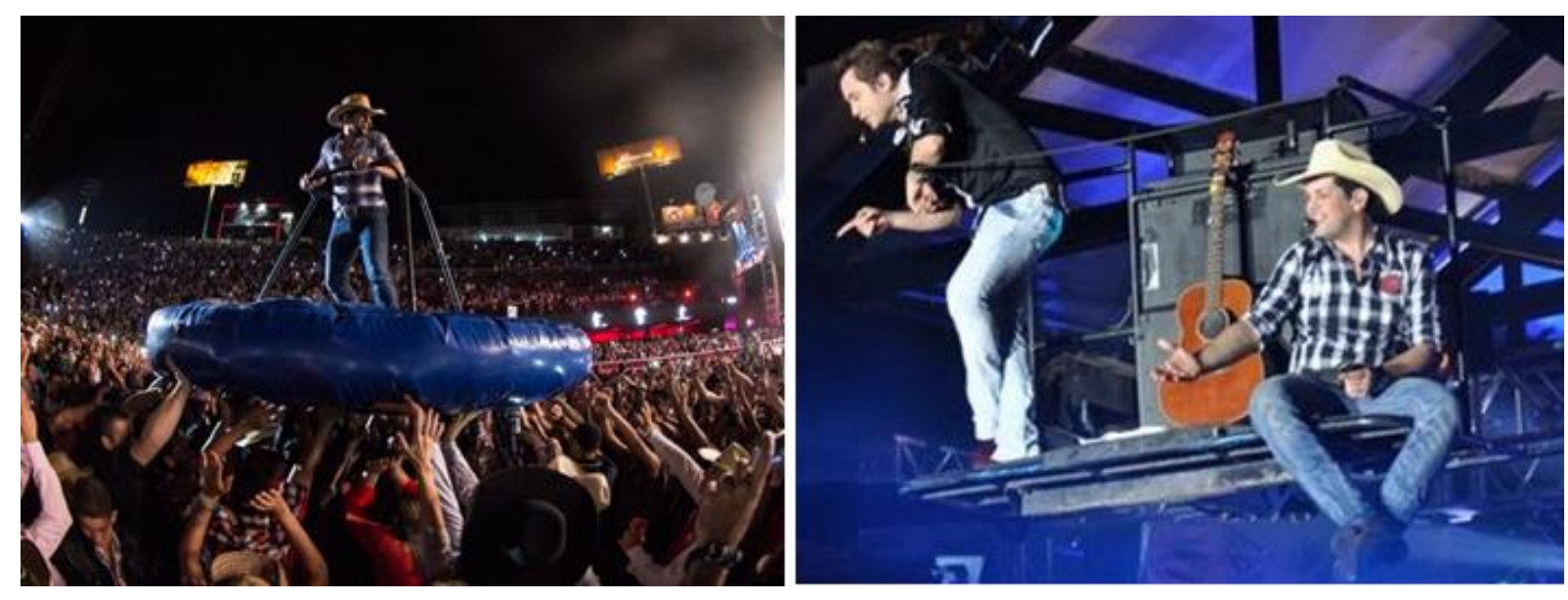

À direita, Sorocaba pilota seu disco voador por cima do público de Barretos e à esquerda, os dois são elevados a 20 m por uma grua. Fonte: Mateus Rigolo/G1 Foto: divulgação.

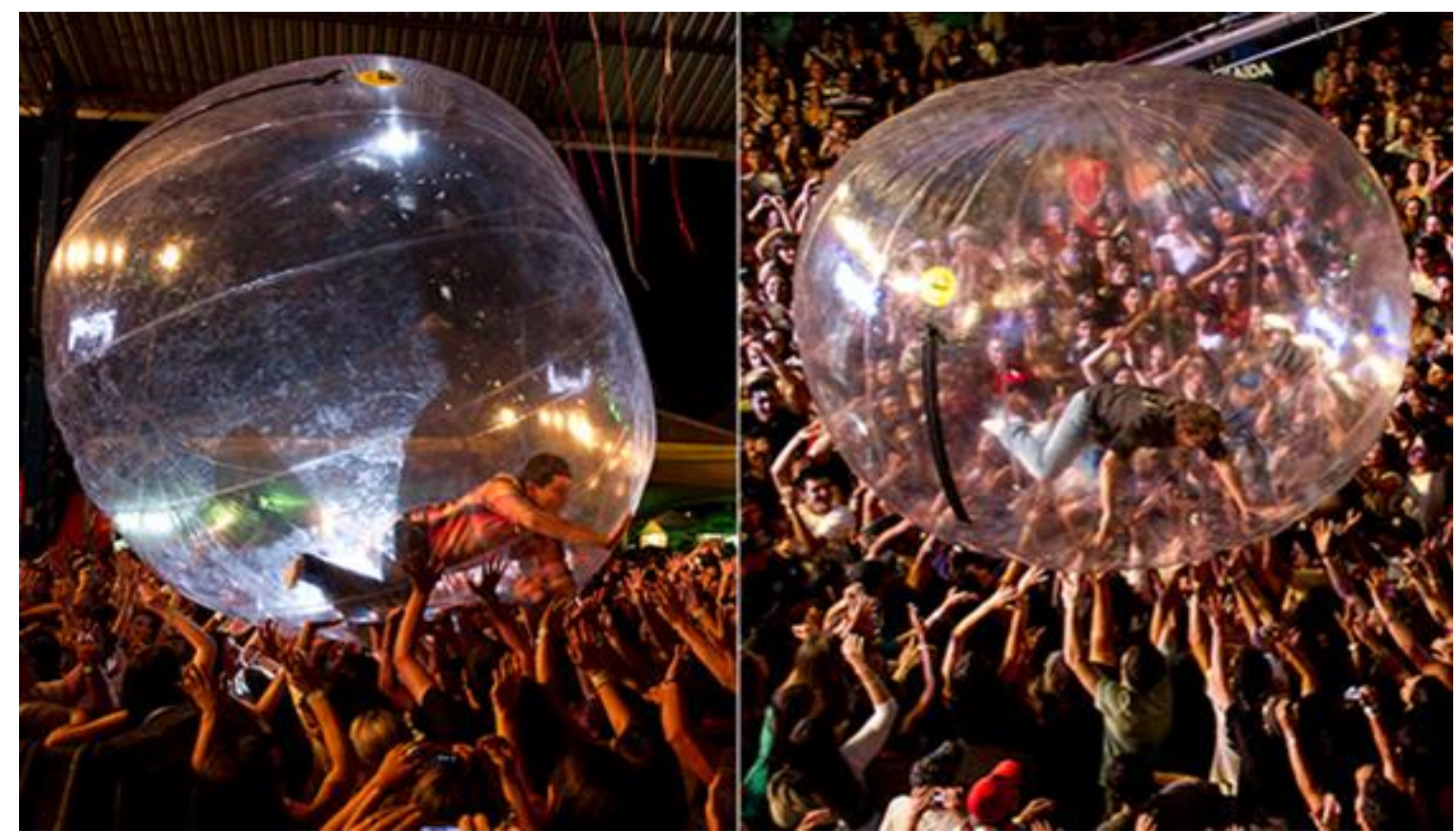

Sorocaba à esquerda e Zorzanello à direita caminham dentro de uma bolha de plástico no meio do público de Barretos. Foto: divulgação. 


\section{CONSIDERAÇÕES FINAIS}

\section{V - Onde fica a universidade do sertão?}

Nas próximas páginas, gostaria de cotejar algumas questões-chave problematizadas ao longo do trabalho. O ponto de partida ideal para isso é a discussão sobre as singularidades sociais do gênero musical abordado. O sucesso comercial da música sertaneja é um caso intrigante na história cultural da música popular brasileira. Em 1929, o folclorista Cornélio Pires foi o responsável pela gravação das primeiras modas de viola em disco e, desde então, o gênero tem testemunhado um êxito comercial excepcional. Entretanto, quais foram as condições objetivas para a existência desse fenômeno? Dos anos 1940 em diante, os artistas sertanejos têm adotado uma estratégia de diferenciação mercadológica estruturalmente simples, embora muito funcional, para a conservação da hegemonia fonográfica: a coexistência da tradição da música sertaneja - o formato dos duetos, o canto de dupla em terça, o uso do violão e as narrativas bucólicas sertanistas e da modernização do gênero - as temáticas urbanas e amorosas, os instrumentos eletrificados, a roupagem moderna e os espetáculos tecnológicos.

Também, graças à assimilação de sonoridades estrangeiras no repertório, a música sertaneja pôde se adaptar às novas configurações exigidas pela indústria fonográfica ao longo dos $\operatorname{anos}^{379}$. Nas décadas de 1940 e 1950, foi assim com a incorporação da rancheira mexicana, das harpas e guarânias paraguaias e do bolero caribenho. Entre 1960, 1970 e 1980, foi a vez do rock and roll inspirado no modelo da Jovem Guarda. Nos anos 1990, a "febre" do country music norte-americano tomou conta dos subcircuitos culturais do gênero, como, por exemplo, as festas do peão de boiadeiro e as feiras agropecuárias. A partir dos anos 2000 , estilos como o folk, o pop, o rock e a balada eletrônica internacional compõem o cenário contemporâneo do gênero. Essa receita de sucesso usada pela música sertaneja pôde reunir um grande público- consumidor de diferentes gerações, faixas etárias, gêneros, estratos sociais, níveis de escolaridade e regiões, em um mesmo repertório. Por sinal, o recém sufixo "universitário" dado à música sertaneja é uma das muitas estratégias usadas para atualização, reconversão social e legitimação cultural desse gênero junto ao público ouvinte. Esses rótulos servem como sinalizadores alegóricos da própria promoção socioeconômica do público-

\footnotetext{
${ }^{379}$ Com a exceção do gênero romântico-nacional, que nunca saiu de moda na música sertaneja.
} 
consumidor desse estilo musical. Nessa balança, os artistas souberam conciliar a tradição ligada à audiência clássica da música sertaneja com a modernização do gênero voltada à nova audiência dos espectadores urbanos.

Nesse sentido, a expressão "sertanejo universitário" é somente mais uma das muitas etiquetas ofertadas pela indústria fonográfica para atualização da embalagem do gênero, com o intuito de torná-la atraente aos novos ouvintes consumidores. Nos tempos atuais, a terminologia "universitária" é vigorosamente contestada pelos artistas sertanejos, mas, em um passado recente, eles foram os maiores beneficiários dessa sacada de marketing. Perante tudo isso, o sufixo "universitário" não pode ser lido como um definidor conceitual ou estético desses novos artistas da música sertaneja. O termo "universitário" foi apenas um rótulo mercadológico e nada mais do que isso. Na realidade, depois de acumular 1.200 páginas em quatro anos de pesquisa, posso abrir do formalismo sociológico e ser enfático: a música sertaneja universitária nunca existiu. Foi uma espécie de subgênero residual e específico, feito por estudantes universitários, como João Bosco e Vinicius e Cesar Menotti e Fabiano, que atuavam como músicos em festas dos cursos de Agronomia e Zootecnia, dentro das universidades federais de Campo Grande (MS) e de Belo Horizonte (MG). Provavelmente, ali existisse uma música sertaneja universitária feita por universitários dentro da universidade. Porém, em um sentido espacial, questiono se um cenário tão restrito como esse seria capaz de criar um movimento propriamente universitário dentro da música sertaneja. Hoje, o públicoconsumidor do gênero é tão abrangente que, talvez, até haja um mercado de música sertaneja, não universitária, mas para universitários - para alunos recém ingressos em uma instituição universitária ou para os estudantes da classe-média emergente que auferem no diploma acadêmico o status cultural que lhes darão acesso a novas oportunidades sociais dentro do mercado de trabalho. Entretanto, essas discussões são hipóteses meramente provisórias, porque exigem um distanciamento histórico, que, infelizmente, a temporalidade histórica deste trabalho não dispõe.

Então, vamos retomar a retórica proposta inicialmente: quais foram as condições objetivas para a existência dessa atualização na música sertaneja? Dos anos 2000 em diante, os novos artistas sertanejos têm apostado em um jogo de diferenciação estética com relação à geração do sertanejo romântico dos anos 1990. O primeiro marcador de distinção foi a temática do cancioneiro. O relacionamento amoroso, melodramático e mal-acabado entre os amantes - ou seja, o enredo da fossa - cedeu espaço à estética da farra, quer dizer, às canções 
destinadas às baladas, às festas e às relações fortuitas entre os jovens. Essa atualização do universo temático da música sertaneja foi acompanhada também de uma nova apropriação instrumental: centralizaram o uso do violão em cordas de aço e do acordeom no lugar de dezenas de instrumentos eletrificados. O canto operístico em alto vibrato e os falsetes nos refrãos foram reduzidos e, assim, a sonoridade ficou mais acústica e menos ruidosa. Os megashows de rock sertanejo, no estilo country norte-americano, dos anos 1990, transformaram-se em uma imensa balada pop sertaneja. Esse rearranjo artístico na carreira dos sertanejos foi condicionado pelas mudanças institucionais dentro do mercado fonográfico nacional.

Em meados dos anos 2000, a indústria musical brasileira foi acometida pela larga crise no comércio discófilo, devido à pirataria e ao aumento do acesso e consumo musical por meio das plataformas digitais. Gradativamente, o peso institucional das gravadoras ficou reduzido, embora elas sejam úteis até hoje, já que possuem as credenciais de acesso aos meios de comunicação de massa, e esse apoio ainda é fundamental à consagração artística nacional. Em meio a esse cenário inóspito, os artistas sertanejos e dos gêneros nordestinos souberam se reinventar e foram os precursores do formato acústico de gravação do DVD ao vivo. Essa reconfiguração mercadológica virou a galinha dos ovos de ouro para os músicos, e eles tomaram para si as rédeas da administração da carreira. Hoje, a rentabilidade financeira da música sertaneja depende quase que exclusivamente do faturamento dos shows ao vivo. $\mathrm{O}$ DVD não é tão rentável assim, mas é um chamariz usado para atrair milhares de espectadores nos estádios espalhados pelos quatro cantos do país.

Umas das modalidades de shows ao vivo são as baladas sertanejas. Em São Paulo, por exemplo, existe a Wood's na Vila Olímpia e a Brooks na Chácara Santo Antônio - bairros de classe-média alta da capital paulistana. O agronegócio e seus subcircuitos culturais (festas do peão e feiras do setor) também promovem os shows desses artistas. Os canais televisivos e radiofônicos mantêm seus papeis tradicionais de divulgação e consagração dos artistas diante da audiência nacional. Mas, sem dúvida alguma, hoje, é a internet a maior responsável pela divulgação da música sertaneja. Sem as gravadoras, as redes sociais como Instagram, Facebook, Twitter e Snapchat são as porta-vozes mediadoras da relação entre público e artista. Lá, os ídolos compartilham fotos dos bastidores, do dia a dia e da família com seus seguidores, e claro, divulgam seus álbuns e as agendas dos shows. O público pode escrever comentários, "curtir" a mensagem e também compartilhar esses conteúdos com outros 
usuários. Os jornais e as revistas continuam conservadores em relação à música sertaneja. $\mathrm{O}$ sucesso nos redutos das casas noturnas de shows metropolitanas não mudou muito a aversão estética e social dos jornalistas ou críticos musicais em relação ao gênero. Porém, hoje em dia, os artistas não se indispõem tanto quanto no passado com as críticas dos setores intelectuais e artísticos. Eles sabem que a legitimidade social não depende exclusivamente da recepção deles, mas sim do êxito comercial.

Nos últimos dezesseis anos, a música sertaneja acompanhou as transformações sociais, econômicas, políticas e culturais do cenário brasileiro. E não foi por acaso que a indústria fonográfica surgiu com a proposta do sufixo "universitário" para atualização do públicoconsumidor do gênero sertanejo. Em uma conjuntura política recém democratizada, assistimos a emergência de uma nova classe-média social, urbanizada e com acesso às novas tecnologias digitais. Na esfera sociocultural, vimos a expansão do sistema de ensino universitário comandada pela iniciativa privada e internacional. Notamos também o aumento significativo de políticas públicas que ampliaram tanto o acesso às instituições públicas ${ }^{380} \mathrm{de}$ ensino superior quanto às instituições particulares ${ }^{381}$. Nesse mesmo período, testemunhamos a disseminação das universidades federais, descentralizadas e espalhadas por dezenas de cidades pelo vasto território nacional. $\mathrm{O}$ sucesso da exportação mundial de commodities do agronegócio deu fôlego a nossa economia ainda incipiente. São essas as condições objetivas e históricas que explicam a existência de uma nova música sertaneja adaptada à nova experiência social do público-consumidor do gênero abordado.

Entretanto, junto ao triunfo comercial e simbólico da nova música sertaneja veio a velha rivalidade entre os artistas do gênero. $\mathrm{O}$ ano de 2007 foi emblemático, pois marcou o auge do movimento universitário e também a estreia de Victor e Leo e de Fernando e Sorocaba na cena musical brasileira. Desde então, os dois duetos mantêm a liderança não só do gênero sertanejo, mas do mercado fonográfico nacional - à frente até mesmo de Roberto Carlos na arrecadação de direitos autorais. Entre os fatores que justificam tal hegemonia, destacam-se: o repertório estritamente autoral; a pluralidade de coletâneas inéditas; a qualidade instrumental, técnica e acústica; o profissionalismo dos músicos da banda; os escritórios e/ou gravadoras de prestígio; a presença em programas televisivos de grande

\footnotetext{
${ }^{380}$ Através do Exame Nacional do Ensino Médio (ENEM).

${ }^{381}$ Por meio da concessão de bolsas integrais e/ou parciais oferecidas pelo Programa Universidade para Todos (ProUni) ou pelos subsídios promovidos pelo Fundo de Financiamento Estudantil (Fies).
} 
audiência; os primeiros lugares na execução radiofônica; a vendagem regular de álbuns; o bom trabalho de divulgação na imprensa; as parcerias com artistas de renome; o apoio de patrocinadores ilustres; a atuação na publicidade e propaganda; uma agenda de shows concorrida; a personificação do carisma cênico e assim por diante. Em quase dez anos, os experientes artistas sertanejos têm mantido uma carreira sólida em um mercado instável e competitivo.

Nesse contexto, foi inevitável a rivalidade entre Victor e Leo e Fernando e Sorocaba. Em um primeiro momento, a disputa mercadológica ainda estava latente: diferenciavam-se uns dos outros somente pela identificação do estilo temático, na apropriação corporal ou nos referenciais estéticos e artísticos. Pouco a pouco, Victor Chaves e Sorocaba não só concorriam pela liderança da lista de arrecadação de direitos autorais do $\operatorname{ECAD}^{382}$, como também objetivavam nas próprias composições uma batalha "silenciosa" de identidades simbólicas dentro da música sertaneja contemporânea. Publicamente, nunca chegaram a pleitear a autenticidade musical de um contra o outro, mas nem por isso o jogo de diferenciações alegóricas e comerciais foi tão sutil assim. Enquanto Fernando e Sorocaba vieram na esteira do sucesso "universitário" da música sertaneja, os irmãos mineiros Victor e Leonardo Chaves contestaram tal "deturpação" cultural do gênero, recuperando o personagem caipira no repertório musical.

Se Fernando e Sorocaba despontavam nas rádios ou nas baladas com enredos como As Mina Pira ou Paga Pau, Victor e Leo cantavam Deus e Eu no Sertão para abertura da novela global Paraíso (2009) ou convidavam Renato Teixeira para gravação da música Vida Boa, no DVD Ao Vivo e Em Cores em São Paulo (2009) ${ }^{383}$. Ao longo do tempo, o teor crítico do compositor Victor Chaves foi se radicalizando. Frequentemente, ele ia à mídia para denunciar a "falta de originalidade" e a "prostituição" dentro da nova música sertaneja. Fernando e Sorocaba sequer discordaram dessas acusações indiretas. Essa reverência a uma suposta tradição do gênero nunca foi uma obsessão para Sorocaba. O empresário optou por investir no mercado do show business, inovando-o com recursos tecnológicos de última geração. Finalmente, a controvérsia artística entre eles foi institucionalizada em 2014. Nesse mesmo ano, Fernando e Sorocaba saíram da gravadora das Organizações Globo (Som Livre) - a

\footnotetext{
${ }^{382}$ Escritório Central de Arrecadação de Direitos Autorais.

${ }^{383}$ Neste mesmo álbum, Victor e Leo trouxeram a participação da cantora Alcione para gravação de Deus e Eu no Sertão.
} 
mesma empresa que, em 2013, recebeu de braços abertos Victor e Leo - e foram para o escritório particular de Sorocaba. Desde então, a competição existente entre os dois duetos foi se instrumentalizando em uma concorrência também institucional entre a FS Produções Artística versus a Som Livre.

No transcorrer dos anos, Victor e Leo e Fernando e Sorocaba foram construindo dois retratos musicais bem singulares: o caipira Galdino e o sertanejo empreendedor. É indispensável antes de discuti-los, examinarmos como cada um dos quatro músicos compõe a personalidade dos seus personagens. Na música sertaneja, Victor Chaves é chamado pelo codinome de "poeta", embora ele se refira a si mesmo como "caipira". O estilo lírico das canções do compositor ganha um charme extra nos palcos. Victor mal abre os olhos durante as apresentações e não se interessa muito em estabelecer contato visual com a plateia. Enquanto dedilha o violão ou a guitarra, o músico encena uma entrega corporal absoluta junto ao instrumento. É como se um "gênio" ou um "espírito da natureza artística pura" tomasse conta de si para fruição plena do deleite musical. Na hora de tomar a palavra no microfone, Victor reproduz a valorização da experiência social, familiar e artística acumulada junto ao irmão caçula. Nos shows, se formos compará-lo a Leo, ele é quase uma figura cênica assexuada e platônica. Pode-se considerá-lo, em uma abordagem eliasiana, como um artista romântico.

O personagem de Leo Chaves é completamente o oposto: um protótipo sexualmente viril do macho-alfa, moreno, alto e robusto. Sob o palco, Leo é o artista-atleta. Ele transforma o show em uma verdadeira maratona: movimenta-se de um lado para o outro, encharcando as roupas de tanto suor. O cantor muda a indumentária conforme o repertório e sabe se posicionar frente às câmeras para ser fotografado e filmado. Em nenhum minuto, ele abandona a interação com a plateia. Leo é um artista carismático, vaidoso e excêntrico e não deixa nada passar batido durante uma apresentação. O habilidoso cantor dá broncas no irmão, nos membros da banda ou até nos organizadores e patrocinadores do show, sem ser grosseiro. No entanto, esse é um novo personagem na carreira de Leo. O selo Som Livre ofereceu uma segunda roupagem a ele. No passado, o artista tinha maior sincronia corporal com o irmão, mas a gravadora das Organizações Globo deu-lhe um trato mercadológico na imagem, explorando seus atributos físicos. 
De dois anos para cá, é nítido o descontentamento de Victor sobre esse novo rumo comercial dado à carreira: o uso do charuto no primeiro dia de gravação do DVD Irmãos é um claro sinal disso. Ele voltou ao palco, olhou para Leo e disse: "Eu me sinto melhor do que você’ ${ }^{384}$. Penso que o compositor só manteve a carreira até aqui por causa dos fortes laços psicossociais estabelecidos com o irmão. Victor resistiu o quanto pôde para conciliar o estilo do seu repertório com a tradição da música sertaneja. $\mathrm{O}$ artista tentou resgatar a figura do caipira e do sertão místico, contrariando as temáticas festivas do gênero e as novas configurações do mercado fonográfico. Talvez, o "caipira lírico" de Victor Chaves seja o último exemplar dessa estirpe na história da música sertaneja comercial.

Essa tensão familiar não existe nos personagens de Fernando e Sorocaba. Na verdade, Fernando Zorzanello é meramente um músico-funcionário de Sorocaba, como tantos outros vistos na nova música sertaneja. Infelizmente, tive pouco acesso às informações sobre a história social de Zorzanello. No entanto, faço um mea-culpa: na ausência de material documental, deveria entrevistá-lo ou abordá-lo nos bastidores dos shows. Em um próximo estudo, espero que essa ausência possa ser preenchida por outros pesquisadores. Na realidade, os nomes Fernando e Sorocaba são um só: Fernando Fakri de Assis - vulgo Sorocaba. O empresário paulista tem edificado um verdadeiro império industrial na música sertaneja. Nos shows, Sorocaba é uma figura carismática, caricatural e excêntrica. O chapéu de caubói, as botas em couro de cobra e o fivelão no cinto são articulados com o sotaque interiorano e o caminhar desengonçado pelo palco. Nos bastidores, o chapéu é substituído pelo boné, a postura corporal é endireitada e o sorriso largo é trocado pelo olhar clínico e técnico.

Nos últimos anos, a atuação artística e empresarial de Fernando/Sorocaba lhe rendeu cifras milionárias. É dono de franquia de balada sertaneja, tem um escritório e uma gravadora particular, é empresário de outras duplas sertanejas, fatura gordos cachês em centenas de shows pelo país, lidera a lista de arrecadação de direitos autorais e outros empreendimentos citados anteriormente ${ }^{385}$. O investimento em capital tecnológico é uma aposta rentável no mercado dos shows e também é o seu diferenciador mercadológico. Em um mesmo show, a inovação tecnológica e os estereótipos da figura cênica de Sorocaba têm a façanha de reunir o ouvinte tradicional e a nova audiência do gênero. No entanto, a ambição do artista vai muito

\footnotetext{
${ }^{384}$ Cf. Capítulo 4.

${ }^{385}$ Cf. Capítulos 2 e 5.
} 
além. Em novembro de 2015, ele estreou nas telonas do cinema o cine-show Anjo de Cabelos Longos. A fusão de longa-metragem e DVD musical é uma tentativa de renovar o formato do gênero sertanejo e também uma aposta para atrair novos consumidores às confortáveis salas cinematográficas. No presente, Fernando Fakri de Assis "Sorocaba" é a personificação bemsucedida do empreendedorismo sertanejo.

Victor e Leo e Fernando e Sorocaba compõem os dois retratos atuais da música sertaneja: o caipira Galdino e o sertanejo empreendedor. A parábola do homem Galdino apresentada na introdução não se refere ao conceito marxista de classe social nem tampouco a “denúncia” ideológica da classe dominante. Desde o início, a alegoria foi usada no sentido de objetivar a contradição existente na linguagem corporal (héxis) de Victor Chaves. Deveras, o compositor resgatou o condão caipira e o sertão místico em inúmeras letras do repertório musical escrito por ele e interpretado na voz do seu irmão caçula, o cantor Leonardo Chaves. No plano do discurso, Victor pedia a "resistência" dos valores "autênticos" do universo cultural da música caipira. Para isso, ele propôs a parceria artística com Renato Teixeira, Almir Sater e outros ícones que fossem sinônimos dessa suposta tradição sertaneja/caipira. Porém, na prática, as mãos do músico revelavam outro tipo de manifestação artística, integralmente incompatível com a linguagem escrita ou proferida por ele. Os acordes dedilhados no violão em cordas de aço ou na guitarra elétrica confessam que a música sertaneja produzida pela dupla não escapou da padronização fonográfica do estilo pop. Portanto, a expressão corporal do compositor contraria o que é dito em seu discurso - Victor Chaves é o retrato musical do caipira Galdino.

Em vista disso, o segundo retrato musical é o do sertanejo empreendedor. Fernando Fakri de Assis "Sorocaba" e Leonardo Chaves exemplificam o novo modelo comercial da música sertaneja. Os dois artistas têm usado o capital artístico acumulado nos últimos anos para reinvesti-lo em empreendimentos lucrativos dentro e fora do setor musical. Mas, eles não são exceções: Michel Teló, Gusttavo Lima, Marcos e Belutti, João Bosco e Vinicius, César Menotti e Fabiano e outros têm usado essa mesma receita de sucesso para alavancar os negócios ${ }^{386}$. Essa prática também não é novidade dentro do gênero. Em duas décadas, Zezé Di Camargo e Luciano e Bruno e Marrone, por exemplo, mantêm com êxito a dupla atuação empresarial e artística. Porém, hoje o comportamento empreendedor dos artistas é mais

\footnotetext{
${ }^{386}$ Cf. Capítulo 1, no item: A moda sertaneja no estilo empreendedor.
} 
ostensivo ou, em outras palavras, é como se existisse um culto de engrandecimento desse tipo de desempenho apoiado pela indústria fonográfica e pelos meios de comunicação de massa.

Efetivamente, o que significa esse protótipo do sertanejo empreendedor? Nada mais é que outra atualização da música sertaneja voltada à nova audiência do gênero. Basta entrar em um show de Fernando e Sorocaba, no Citibank Hall de São Paulo, para notar o vasto público masculino que se veste como Sorocaba: chapéu de caubói, fivelona, cintos e botas excêntricas. Lá, esses mesmos homens interioranos encontram na música sertaneja uma retradução objetiva das novas condições sociais que eles vivenciam. Inclusive, o próprio êxito econômico do agronegócio só foi possível graças à modernização do campo brasileiro. Em um espetáculo sertanejo, a tradição da música sertaneja coexiste com a modernidade tecnológica do gênero - ali, o público pode experimentar, por meio da música, o retrato verossímil do seu status dentro da hierarquia social. Se a música sertaneja universitária nunca teve um consenso estético dos artistas para se estabelecer como um novo subgênero, pode-se dizer que, hoje, o conceito de sertanejo empreendedor é unânime na música sertaneja.

Durante o registro etnográfico dos shows de Victor e Leo e Fernando e Sorocaba, observei o comportamento inusitado de jogos eróticos cênicos entre os artistas e o público e também entre a plateia. No primeiro caso, há uma divisão de papeis: Victor é o personagem do compositor romântico assexuado que atrai exclusivamente o amor platônico das espectadoras. Ele tem o rosto belo e delicado, com proporções áureas e traços europeus. O cabelo tem textura lisa e a coloração tem a nuance de louro-escuro acinzentado misturado com os fios grisalhos. O olho direito é levemente caído, o que lhe dá um toque de charme. Tem 1,82 de altura e poucos pelos corporais. Leo Chaves é a figura cênica do macho-alfa que centraliza a tensão sexual da audiência feminina para si. O cantor tem a pele morena e bronzeada, um porte físico atlético, mede 1,94 de altura e usa ternos ou regatas justas. Esse arquétipo do amante latino-americano mexe com o imaginário afetivo das mulheres. Tanto é que, depois do show, elas o esperam por longas horas no estacionamento somente para abraçá-lo ou beijá-lo, e não é difícil vê-las entregar algum mimo ao cantor.

Embora haja essa tensão sexual entre Fernando e Sorocaba e a plateia, ela é bem menor se comparada a Victor e Leo. Os dois não são feios, mas digamos que eles não têm um padrão de beleza corporal e facial tão excepcional quanto os irmãos mineiros. Fernando tem o estilo roqueiro, com tatuagens, mexas louras nos cabelos e usa calças e coletes de couro. 
Sorocaba não dispensa o chapéu de caubói no estilo texano nem os adereços extravagantes. As calças jeans vestidas pelo cantor são tão justas que é possível ver as marcas dos órgãos genitais. Entretanto, o jogo erótico é visto em meio à plateia. O show de Fernando e Sorocaba tem mais status de balada eletrônica pop do que de um evento artístico de música sertaneja. As composições de Sorocaba exaltam por si só esse ambiente marcado pela estética da farra e da diversão festiva. Nessas apresentações, dois perfis de consumidores são reunidos: os homens quarentões ou cinquentões que se vestem como Sorocaba e são acompanhados por mulheres jovens e bonitas, e os grupos de rapazes e moças solteiras entre 18 a 30 anos que vão até o show para paquerar.

Infelizmente, não houve tempo hábil na pesquisa para montar um estudo específico sobre a recepção do público-consumidor da música sertaneja em São Paulo. Durante a pesquisa de campo, observei que existe uma heterogeneidade de perfis de consumidores que compõem a nova audiência do gênero sertanejo. Consequentemente, esse é um importante capítulo a ser feito por futuros pesquisadores acadêmicos que queiram adensar a discussão dessa temática. Outro item ausente neste trabalho é a análise comparativa de demais duplas ou artistas sertanejos da nova geração. Por uma questão de tempo e financiamento, delimitei no estudo de caso somente os duetos sertanejos (Victor e Leo e Fernando e Sorocaba) de maior notoriedade no cenário musical dos últimos dez anos. Espero que essa lacuna possa despertar o interesse de novos estudiosos para a compreensão do fenômeno cultural abordado neste trabalho. Gostaria de registrar aqui uma última sugestão. Na capital paulistana, existe um circuito de casas noturnas (baladas ou barzinhos com música ao vivo) voltadas exclusivamente para o gênero. $\mathrm{O}$ mapeamento etnográfico desses espaços oferece valiosas descrições analíticas, pois dá ao pesquisador o acesso irrestrito aos artistas, músicos, produtores, empresários, espectadores e também aos cenários.

Por fim, onde fica a universidade do sertão? De modo não sistêmico, essa questão já foi respondida na introdução e nos cinco capítulos anteriores, mas irei recuperá-la aqui. Nos anos 1970 e 1980, a música sertaneja foi resgatada como alternativa crítica do modelo nacional popular de "resistência" cultural das esquerdas intelectuais e artísticas ligadas à universidade. O selo de autenticidade desse sertão "puro" e "mitológico" foi uma construção artística-intelectual, institucional, geracional e datada. Portanto, o sertão da universidade não existe mais. Hoje, esse mesmo sertão foi reinventado e institucionalizado, não pela universidade, mas pelos escritórios particulares e pelas gravadoras comerciais estabelecidas 
no âmago da indústria fonográfica. O sertão foi instrumentalizado também nas mãos dos sertanejos empreendedores, como Fernando Fakri de Assis "Sorocaba" e Leonardo Chaves, ou seja, pelos próprios artistas da música sertaneja. Em pouco tempo, o sertão se atualizou e foi se transformando na universidade do sertão - uma instituição do capitalismo moderno, tecnológica, lucrativa e estritamente mercadológica. $\mathrm{Na}$ época atual, os sertanejos empreendedores são os mestres e doutores da universidade do sertão. Este é o novo retrato cultural da música sertaneja. 


\section{ANEXO A - Monitoramento da audiência radiofônica de Victor e Leo e Fernando e Sorocaba (Ranking Crowley)}

\begin{tabular}{|c|c|c|c|c|}
\hline Período & $\begin{array}{c}\text { Victor \& } \\
\text { Leo }\end{array}$ & Canção de V\&L & $\begin{array}{c}\text { Fernando \& } \\
\text { Sorocaba }\end{array}$ & Canção de F\&S \\
\hline $29 / 06$ a $05 / 07$ & $2^{\circ}$ & O Tempo Não Apaga & -- & -- \\
\hline $06 / 07$ a $12 / 07$ & $3^{\circ}$ & O Tempo Não Apaga & -- & -- \\
\hline $13 / 07$ a $19 / 07$ & $3^{\circ}$ & O Tempo Não Apaga & -- & -- \\
\hline $20 / 07$ a $26 / 07$ & $7^{\circ}$ & O Tempo Não Apaga & $8^{\circ}$ & Mármore \\
\hline $27 / 07$ a $02 / 08$ & $1^{\circ}$ & Tudo Com Você & $10^{\circ}$ & Mármore \\
\hline 03/08 a 09/08 & $1^{\circ}$ & Tudo Com Você & $6^{\circ}$ & Mármore \\
\hline $10 / 08$ a $16 / 08$ & $1^{\circ}$ & Tudo Com Você & $5^{\circ}$ & Mármore \\
\hline $17 / 08$ a 23/08 & $1^{\circ}$ & Tudo Com Você & $7^{\circ}$ & Mármore \\
\hline $24 / 08$ a $30 / 08$ & $1^{\circ}$ & Tudo Com Você & $7^{\circ}$ & Mármore \\
\hline $31 / 08$ a 06/09 & $1^{\circ}$ & Tudo Com Você & $8^{\circ}$ & Mármore \\
\hline 07/09 a 13/09 & $1^{\circ}$ & Tudo Com Você & $7^{\circ}$ & Mármore \\
\hline $14 / 09$ a 20/09 & $1^{\circ}$ & Tudo Com Você & $8^{\circ}$ & Mármore \\
\hline $21 / 09$ a $27 / 09$ & $1^{\circ}$ & Tudo Com Você & -- & -- \\
\hline 28/09 a 04/10 & $1^{\circ}$ & Tudo Com Você & -- & -- \\
\hline $05 / 10$ a $11 / 10$ & $1^{\circ}$ & Tudo Com Você & -- & -- \\
\hline $12 / 10$ a $18 / 10$ & $1^{\mathrm{o}}$ & Tudo Com Você & -- & -- \\
\hline $19 / 10$ a $25 / 10$ & $1^{\circ}$ & Tudo Com Você & -- & -- \\
\hline $26 / 10$ a $01 / 11$ & $1^{\circ}$ & Tudo Com Você & -- & -- \\
\hline $02 / 11$ a $08 / 11$ & $1^{\circ}$ & Tudo Com Você & -- & -- \\
\hline $09 / 11$ a $15 / 11$ & $2^{\circ}$ & Tudo Com Você & -- & -- \\
\hline $16 / 11$ a $22 / 11$ & $2^{\circ}$ & Tudo Com Você & -- & -- \\
\hline $23 / 11$ a $29 / 11$ & $3^{\circ}$ & Tudo Com Você & -- & -- \\
\hline $30 / 11$ a $06 / 12$ & $3^{\circ}$ & Tudo Com Você & -- & -- \\
\hline $07 / 12$ a $13 / 12$ & $5^{\circ}$ & Tudo Com Você & -- & -- \\
\hline $14 / 12$ a $10 / 12$ & $4^{\circ}$ & Tudo Com Você & $3^{\circ}$ & Bobeia Pra Ver \\
\hline $21 / 12$ a $27 / 12$ & $7^{\circ}$ & Tudo Com Você & $3^{\circ}$ & Bobeia Pra Ver \\
\hline $04 / 01$ a $10 / 01$ & $7^{\circ}$ & Tudo Com Você & $5^{\circ}$ & Bobeia Pra Ver \\
\hline $11 / 01$ a $27 / 01$ & -- & -- & $6^{\circ}$ & Bobeia Pra Ver \\
\hline $18 / 01$ a $24 / 01$ & -- & -- & $5^{\circ}$ & Bobeia Pra Ver \\
\hline $25 / 01$ a $31 / 01$ & -- & -- & $7^{\circ}$ & Bobeia Pra Ver \\
\hline $01 / 02$ a 07/02 & -- & -- & $5^{\circ}$ & Bobeia Pra Ver \\
\hline
\end{tabular}




\section{ANEXO B - Agenda musical de Victor e Leo e Fernando e Sorocaba}

\begin{tabular}{|c|c|c|}
\hline $\begin{array}{c}\text { Calendário do } \\
\text { segundo semestre } \\
\text { de 2014: shows, e } \\
\text { eventos na TV e } \\
\text { nas rádios. } \\
\end{array}$ & Victor e Leo & Fernando e Sorocaba \\
\hline AGOSTO & $\begin{array}{l}\text { 28/ Terra Country Interlagos. } \\
\text { 29/ Festa do Peão de Boiadeiro de } \\
\text { Barretos, } 2014 .\end{array}$ & $\begin{array}{l}\text { 28/ Festa do Peão de Boiadeiro de } \\
\text { Barretos, } 2014 .\end{array}$ \\
\hline SETEMBRO & $\begin{array}{l}\text { 06/ Altas Horas - Rede Globo. } \\
\text { 20/ Villa Mix - festival. } \\
\text { 22/ Gravação do Programa da Sabrina } \\
\text { Sato, Rede Record. } \\
\text { 23/ Tropical FM, Band FM e Nativa } \\
\text { FM. } \\
\text { 25/ Gravação no Programa de Danilo } \\
\text { Gentile, The Noite, Canal SBT. }\end{array}$ & $\begin{array}{l}\text { 20/ Villa Mix - festival. } \\
\text { 20/ Gravação no Programa Festival } \\
\text { Sertanejo, apresentado por Chitãozinho } \\
\text { \& Xororó no Canal SBT. } \\
26 \text { e 27/ Citibank Hall. }\end{array}$ \\
\hline OUTUBRO & $\begin{array}{l}\text { 03/ Espaço das Américas. } \\
\text { 18/ Gravação no Programa Festival } \\
\text { Sertanej, apresentado por } \\
\text { Chitãozinho \& Xororó, no Canal SBT. } \\
\text { 19/ Bem Sertanejo - Rede Globo. }\end{array}$ & $\begin{array}{l}\text { 10/10 Terra Country Interlagos. } \\
\text { 18/ Evento Corporativo - Clube } \\
\text { Pinheiros. } \\
\text { 19/ Bem Sertanejo - Rede Globo. }\end{array}$ \\
\hline NOVEMBRO & $\begin{array}{l}\text { 08/Teleton - Canal SBT. } \\
\text { 23/Participação da festa de aniversário } \\
\text { da rádio paulista Nativa FM. }\end{array}$ & $\begin{array}{l}\text { 27/ Villa Country. } \\
23 \text { de novembro - Programa da Eliana } \\
\text { - Canal SBT } \\
\text { 28/ Altas Horas - Rede Globo. }\end{array}$ \\
\hline DEZEMBRO & $\begin{array}{l}\text { 02/ Sai do Chão - Rede Globo. } \\
\text { 03/ Corujão do Esporte - Rede Globo. } \\
\text { 09/ Vídeo Show - Rede Globo. } \\
12 \text { e 13/ Citibank Hall. } \\
\text { 14/ Sintonize - Rede Globo. } \\
\text { 20/ Show Business - Canal Band. } \\
\text { 21/ Programa Rodrigo Faro - Rede } \\
\text { Record. } \\
\text { 22/ Natal Mágico da Xuxa - Canal } \\
\text { Viva. }\end{array}$ & $\begin{array}{l}\text { 03/ Conexão Repórter - Canal SBT. } \\
\text { 07/ TOP FM. } \\
\text { 13/ Mais Caminhos - EPTV/Rede } \\
\text { Globo. }\end{array}$ \\
\hline
\end{tabular}




\section{REFERÊNCIAS BIBLIOGRÁFICAS}

ABREU, Ieda de. Rolando Boldrin: Palco Brasil. Imprensa Oficial do Estado de SP. São Paulo. 2005.

ADORNO, Theodor; HORKHEIMER, Max. A Dialética do Esclarecimento. Rio de janeiro: Zahar, 1985.

ADORNO, Theodor. Indústria Cultural e Sociedade. São Paulo: Paz e Terra, 2002.

Introdução à Sociologia da Música. São Paulo: Editora: UNESP, 2011.

ALONSO, Gustavo. Cowboys do Asfalto: Música Sertaneja e Modernização Brasileira. Tese de doutorado apresentada à Universidade Federal Fluminense, Rio de Janeiro, 2011.

ARAÚJO, Paulo César. Eu Não Sou Cachorro, Não: Música Popular Cafona e Ditadura Militar. São Paulo: Record, 2002.

ARRUDA, Maria Arminda do Nascimento. Metrópole e Cultura. São Paulo: EDUSC, 2001.

BENJAMIN, Walter. A Obra de Arte na Época da sua Reprodutibilidade Técnica (publicado em 1936). In: Os Pensadores - História das Grandes Ideais do Mundo Ocidental. São Paulo: Editora: Abril, 1975.

BONADIO, Geraldo; SAVIOLI, Ivone. Música Sertaneja e Classes Subalternas. In: MELO José Marques de (org.) Comunicação e Classes Subalternas. São Paulo: Cortez, 1980.

BOURDIEU, Pierre. Questões de Sociologia. Tradução: Jeni Vaitsman. Rio de Janeiro: Marco Zero, 1983.

Esboço de uma Teoria da Prática. In: ORTIZ, Renato (Org.) Pierre Bourdieu. São Paulo: Ática, 1983. 
. Coisas Ditas. São Paulo: Editora Brasiliense, 1990.

. Estruturas Sociais e Estruturas Mentais (Prólogo à La Noblesse d'État). Teoria \& Educação: Porto Alegre, 1991.

. As Regras da Arte: Gênese e Estrutura do Campo Literário. São Paulo: Companhia das Letras, 1992.

Razões Práticas: Sobre a Teoria da Ação. Campinas: Papirus, 1996.

A Ilusão Biográfica. In: FERREIRA, Marieta de Moraes; AMADO, Janaína (Org.). Usos e Abusos da História Oral. Rio de Janeiro: Editora da Fundação Getúlio Vargas, 1996.

. Sobre a Televisão - A Influência do Jornalismo e os Jogos Olímpicos. Rio de Janeiro: Zahar, 1997.

. Meditações Pascalianas. Tradução de Sergio Miceli. Rio de Janeiro: Bertrand Brasil, 2001.

e DARBEL. O Amor pela Arte: Os Museus de Arte na Europa e seu Público. São Paulo: Editora da Universidade de São Paulo, 2003.

. Para uma Sociologia da Ciência. Lisboa: Edições 70, 2004.

_. Esboço de Autoanálise. Tradução Sergio Miceli. São Paulo: Companhia das Letras, 2005 .

A Distinção. Crítica Social do Julgamento. Tradução Daniela Kern; Guilherme J.F. Teixeira. São Paulo: Edusp: Porto Alegre: Zouk, 2007.

O Poder Simbólico. Tradução: Fernando Tomaz. Rio de Janeiro: Bertrand Brasil, 2007. 
A Economia das Trocas Simbólicas. 6ed: Tradução de Sergio Miceli. São Paulo: Editora Perspectiva, 2007.

e PASSERON, Jean-Claude. Os Herdeiros: Os Estudantes e a Cultura. Florianópolis: Editora da UFSC, 2014.

CALDAS, Waldenyr. Acorde na Aurora: Música Sertaneja e Indústria Cultural. Cia Ed. Nacional. São Paulo. 1977.

. O que é Música Sertaneja. Brasiliense: São Paulo. 1987.

Luz Neon: Canção e Cultura na Cidade. SESC: São Paulo, 1995.

A Cultura Político-Musical Brasileira. Editora Musa: São Paulo, 2005.

CANDIDO, Antonio. Os Parceiros do Rio Bonito: Estudo sobre o Caipira Paulista e a Transformação dos seus Meios de Vida (publicado originalmente em 1964), 4ed. Livraria Duas Cidades Ltda. São Paulo. Edição. 1977. . A Formação da Literatura Brasileira, 2ed. São Paulo: Editora Martins, 1964.

DANTAS, Macedo. Cornélio Pires: Criação e Riso. Livraria Duas Cidades: São Paulo, 1976.

DIAS, Marcia Tosta. Os Donos da Voz: Indústria Fonográfica Brasileira e Mundialização da Cultura. São Paulo: Boitempo, 2000.

ECO, Umberto. Apocalípticos e Integrados. São Paulo: Editora Perspectiva, 1979.

ELIAS, Norbert. A Sociedade dos Indivíduos. Rio de Janeiro: Jorge Zahar, 1994. . Mozart, Sociologia de um Gênio. Rio de Janeiro: Zahar, 1995. Os Estabelecidos e os Outsiders. Rio de Janeiro: Zahar, 2000. 
A Sociedade de Corte. Rio de Janeiro: Jorge Zahar, 2001.

FAUSTINO, Jean Carlo. A Moda de Viola na Era da sua Reprodutibilidade Técnica. Trabalho apresentado na ANPOCS, 2009.

FERNANDES, Dmitri Cerboncini. A Inteligência da Música Popular: A "autenticidade" no Samba e no Choro. Tese de doutorado apresentado ao programa de pós-graduação em sociologia da Universidade de São Paulo, 2010.

FERRETE, J. L. Capitão Furtado: Viola Caipira ou Sertaneja? Instituto Nacional de Música, Divisão de Música Popular. Rio de Janeiro: Funarte, 1985.

FRITH. Simon. The Industrialization of Popular Music. In: LULL, James (org). Popular Music and Communication. Cambridge: Sage Publications, 1992.

GOFFMAN, Erving. A Representação do Eu na Vida Cotidiana. $13^{\mathrm{a}}$ ed. Rio de Janeiro: Editora: Vozes, 1975.

_. Estigma- Notas sobre a Manipulação da Identidade Deteriorada. Rio de Janeiro: Zahar, 1980.

Ritual de Interação: Ensaios Sobre o Comportamento Face a Face. Petrópolis, Editora Vozes, 2011.

GONÇALVES, Camila Koshiba. Música em 78 rotações: Discos a todos os preços na São Paulo dos anos 30. São Paulo: Editora Alameda, 2013.

HOLANDA, Sérgio Buarque. Índios e Mamelucos na Expansão Paulista. Anais do Museu Paulista vol. XIII 1949.

KRAUSCHE, Valter. Música Popular Brasileira: Da Cultura de Roda à Música de Massa. São Paulo: Brasiliense. 1983.

KRACAUER, Siegfried. O Ornamento da Massa: Ensaios. São Paulo: Cosac Naify, 2009. 
LOBATO, Monteiro. Urupês. In: Lobato, M. Obras Completas. São Paulo: Brasiliense. 1959. O Problema Vital. São Paulo: Sociedade de Eugenia de São Paulo, 1918.

MAGI, Érica Ribeiro. "Rock and Roll é o Nosso Trabalho”: a Legião Urbana do Underground ao Mainstream. São Paulo: Editora Alameda/FAPESP, 2013.

MARTÍN-BARBEIRO, Jesús. Memória Narrativa e Indústria Cultural. In: Comunicacíon y Cultura (comunicacíon massiva em el processo político latino-americano), n.10, 1983.

MARTINS, José de Souza. Música Sertaneja: A Dissimulação na Linguagem dos Humilhados. In: Martins, Capitalismo e Tradicionalismo. Pioneira. São Paulo. 1975. A Música Sertaneja entre o Pão e o Circo. In: Travessia, 1990.

MICELI, Sergio. A Noite da Madrinha. São Paulo: Perspectiva, 1972.

Imagens Negociadas: Retratos da Elite Brasileira (1920-40). São Paulo: Companhia das Letras, 1996.

Nacional Estrangeiro: História Social e Cultural do Modernismo Artístico em São Paulo. São Paulo: Companhia das Letras, 2003.

MONTEIRO, Guilherme Seto. Condão Caipira: Produção e Recepção do Cinema de Amácio Mazzaropi. Dissertação de mestrado apresentada à Universidade de São Paulo, 2013.

MUGNAINI Jr, Ayrton. Enciclopédia das Músicas Sertanejas. Rio de Janeiro: Letras \& Letras. 2001.

NAPOLITANO, Marcos. Seguindo a Canção: Engajamento Político e Indústria Cultural na MPB (1959-1969). São Paulo: Annablume/FAPESP. 2001. 
- História \& Música - História Cultural da Música Popular. Belo Horizonte: Autêntica, 2005.

A Síncope das Ideias: A Questão da Tradição na Música Popular Brasileira. São Paulo: Editora da Fundação Perseu Abramo, 2007.

NAVES, Santuza Cambraia. O Violão Azul: Modernismo e Música Popular. Rio de Janeiro: Editora Fundação Getúlio Vargas, 1998.

Canção Popular no Brasil: A Canção Crítica. Rio de Janeiro: Civilização Brasileira, 2010 .

NEPOMUCENO, Rosa. Música Caipira: Da Roça ao Rodeio. Editora 34: São Paulo, 1999.

OLIVEIRA, Allan de Paula. O Tronco da Roseira: Uma Antropologia da Viola Caipira. Dissertação de mestrado apresentada à Universidade Federal de Santa Catarina, 2004.

Miguilim Foi pra Cidade ser Cantor: Uma Antropologia da Música Sertaneja. Tese de doutorado apresentada à Universidade Federal de Santa Catarina, 2009.

ORTIZ, Renato. Cultura Brasileira \& Identidade Nacional. São Paulo: Brasiliense, 1985.

- A Moderna Tradição Brasileira: Cultura Brasileira e Indústria Cultural. $2^{\mathrm{a}}$ ed. São Paulo: Brasiliense, 1989.

PETERSON, Richard. Creating Country Music: Fabrication Authenticity. Chicago University Press, 1978.

PIMENTEL, Sidney Valadares. O Chão é o Limite: A Festa de Peão de Boiadeiro e a Domesticação do Sertão. Goiás: Editora UFMG, 1997.

PIRES, Cornélio. Conversas ao Pé do Fogo. São Paulo: Tipografia Piratininga. 1921. 
PULICI, Carola Martins. O Charme (In) Discreto do Gosto Burguês Paulista: Estudo Sociológico da Distinção Social em São Paulo. Tese de doutorado apresentada à Universidade de São Paulo, 2010.

REILY, Suzel Ana. Música Sertaneja and Migrant Identity; The Stylistic Development of a Brazilian Genre. Popular Music, vol.11, n.3, p.337-358, 1992.

RIBEIRO, José Hamilton. Música Caipira: As 270 Maiores Modas de Todos os Tempos. São Paulo: Globo. 2006.

RIDENTI, Marcelo. Em Busca do Povo Brasileiro: Artistas da Revolução, do CPC à Era da TV. Rio de Janeiro: Editora: Record. 2000.

Caleidoscópio da Cultura Brasileira - 1964-2000. In: MICELI, Sergio; PONTES, Heloisa (orgs.). Cultura e Sociedade: Brasil e Argentina. São Paulo: Edusp, 2014.

SAINT-HILAIRE, Auguste. Segunda Viagem do Rio de Janeiro a Minas Gerais e São Paulo (1822). Companhia Editora Nacional: São Paulo, 1932.

- Viagens à Província de São Paulo e Resumo das Viagens ao Brasil, Cisplatina e Missões do Paraguai. Livraria Martins: São Paulo, 1940.

SANT’ANNA, Romildo. A Moda é Viola: Ensaio do Cantar Caipira. São Paulo: Arte \& Ciência; Marília, SP: Ed. UNIMAR. 2000.

SOUZA, Gilda de Mello e. Pintura Brasileira Contemporânea. In: Exercícios de Leitura. São Paulo: Duas Cidades, 1980.

SOUZA, Walter de. Moda Inviolada: Uma História da Música Caipira. Quíron Livros. São Paulo. 2005.

TINHORÃO, José Ramos. Pequena História da Música Popular: Da modinha à Canção de Protesto. Editora: Vozes: Rio de Janeiro, 1974. 
Música Popular: Do gramofone ao Rádio e TV. São Paulo: Editora Ática, 1981.

. Pequena História da Música popular: Da Modinha ao Tropicalismo. São Paulo: Art Editora, 1986.

TOLENTINO, Célia Aparecida Ferreira. O Rural no Cinema Brasileiro. São Paulo: Editora: UNESP, 2001.

ULHÔA, Martha Tupinambá de. Música Sertaneja e Globalização. In: TORRES, Rodrigo (org.). Actas Del II Congresso Latino-americano IASPM. São Paulo: Fondart, 1999.

VILELA, Ivan. Cantando a Própria História: Música Caipira e Enraizamento. São Paulo: EDUSP, 2014.

ZAN, José Roberto. Música Caipira: Da Roça a Nashville. Revista do Núcleo de Desenvolvimento da Criatividade da Unicamp. Campinas: NUDECRI, 1994.

_. Música Popular Brasileira, Indústria Cultural e Identidade. Grupo de Trabalho no XIII Encontro da ANPPOM. In: Eccos Revista Científica, ${ }^{\circ}$ 1, vol.3, ano 001. São Paulo: Uninove, 2001.

. (Des) Territorialização e Novos Hibridismos na Música Sertaneja. In: Revista Sonora, 2008 .

WILLIAMS, Raymond. Marxismo e Literatura. Rio de Janeiro: Zahar, 1979.

O Campo e a Cidade na História e na Literatura. São Paulo: Companhia das Letras, 1989.

. Cultura. São Paulo: Paz e Terra, 2000.

. Política do Modernismo: Contra os Novos Conformistas. São Paulo:

UNESP, 2011. 


\section{Entrevistas ao autor}

Helder Maldonado. 18 de setembro de 2014. São Paulo-SP.

Marcos Napolitano. 07 de novembro de 2014. São Paulo-SP.

André Piunti. 22 de novembro de 2014. São Paulo-SP.

Ivan Vilela. 28 de novembro de 2014. São Paulo-SP.

Fernando Fakri de Assis (Sorocaba). 08 de abril de 2015. São Paulo-SP.

Victor Chaves. 09 de julho de 2015. São Paulo-SP.

\section{Filmes e documentários}

Anjo de Cabelos Longos. Direção: Fernando Trevisan, 2015.

Nada És Normal. Gravado em espanhol. Direção: Sony-BMG (Brasil), 2008.

Victor \& Leo - A História. Direção: Sérgio Bittencourt, 2010.

Vou Rifar Meu Coração. Direção: Ana Rieper, 2012.

\section{Institutos oficiais de pesquisa}

ECAD - Escritório Central de Arrecadação e Distribuição.

Crowley Broadcast Analysis do Brasil.

IBOPE - Instituto Brasileiro de Opinião Pública e Estatística.

Target Group Index - IBOPE Media. 


\section{Programas televisivos}

Fantástico, TV Globo, exibido: 19 de outubro de 2014.

Globo Rural, TV Globo, exibido: 11 de janeiro de 2015.

\section{Websites acessados}

Blognejo: http://blognejo.com.br

Cidade Verde: $\underline{\text { http://cidadeverde.com }}$

Eco Agro: http://www.ecoagro.agr.br

Ego/Globo: http://ego.globo.com

Extra/Globo: http://extra.globo.com

G1/Globo: http://g1.globo.com

Glamurama: http://glamurama.uol.com.br/tag/revista-poder

Gshow/Globo: http://gshow.globo.com

Hits FM: http://fmhits.com.br

IG Sertanejo: http://sertanejo.ig.com.br

Jornal do Brasil: http://www.jb.com.br

Jornal Gazeta do Povo: http://www.gazetadopovo.com.br

Jornal $O$ Globo: http://oglobo.globo.com 
Jornal Opção: http://www.jornalopcao.com.br

Jovem Pan/UOL: http://jovempan.uol.com.br

Movimento Country: http://www.movimentocountry.com

Portal R7: http://www.r7.com

Portal Sucesso: http://www.portalsucesso.com.br

República Rodeio: http://www.republicarodeio.com

Revista Billboard Brasil: http://www.billboard.com.br

Revista Época/Globo: http://epoca.globo.com

Revista Forbes: http://www.forbes.com.br

Revista $G Q: \underline{\text { http://gq.globo.com }}$

Revista Isto é Dinheiro: http://www.istoedinheiro.com.br

Revista Poder: http://glamurama.uol.com.br/tag/revista-poder

Revista Veja: http://veja.abril.com.br

Sertanejo Top: http://www.sertanejotop.com.br

Site oficial de Victor e Leo: http://www.victoreleo.com

Site oficial de Fernando e Sorocaba: http://www.fernandoesorocaba.com.br

TV Foco: http://otvfoco.com.br 
TV Sertaneja: http://www.tvsertaneja.com.br

UOL Entretenimento: http://entretenimento.uol.com.br

UOL Música: $\underline{\text { http://musica.uol.com.br }}$

Universo Sertanejo: http://www.universosertanejo.com.br 